\title{
DỨcin
}

Technological University Dublin ARROW@TU Dublin

\section{France and Ireland in the Public Imagination}

\author{
Benjamin Keatinge \\ Mary Pierse
}

Follow this and additional works at: https://arrow.tudublin.ie/afisbo

Part of the Arts and Humanities Commons

\section{Recommended Citation}

Keatinge, Benjamin and Pierse, Mary, "France and Ireland in the Public Imagination" (2014). Books. 9. https://arrow.tudublin.ie/afisbo/9

This Book is brought to you for free and open access by the AFIS (Association of Franco-Irish Studies) Publications at ARROW@TU Dublin. It has been accepted for inclusion in Books by an authorized administrator of ARROW@TU Dublin. For more information, please contact arrow.admin@tudublin.ie, aisling.coyne@tudublin.ie, gerard.connolly@tudublin.ie.

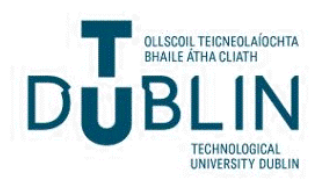


France and Ireland in the Public Imagination 


\section{Reimagining Ireland}

Volume 55

Edited by Dr Eamon Maher

Institute of Technology, Tallaght

PETER LANG

Oxford $\bullet$ Bern $\bullet$ Berlin $\bullet$ Bruxelles $\bullet$ Frankfurt am Main $\bullet$ New York $\bullet$ Wien 
Benjamin Keatinge and Mary Pierse (eds)

\section{France and Ireland in the \\ Public Imagination}

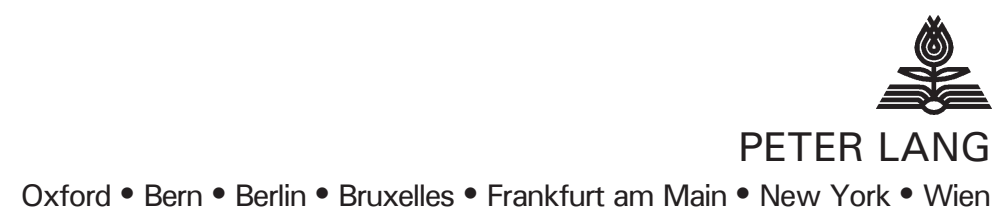


Bibliographic information published by Die Deutsche Nationalbibliothek.

Die Deutsche Nationalbibliothek lists this publication in the Deutsche Nationalbibliografie; detailed bibliographic data is available on the Internet at http://dnb.d-nb.de.

A catalogue record for this book is available from the British Library.

Library of Congress Control Number: 2014934038

ISSN 1662-9094

ISBN 978-3-0343-1747-4

(C) Peter Lang AG, International Academic Publishers, Bern 2014 Hochfeldstrasse 32, CH-3012 Bern, Switzerland

info@peterlang.com,www.peterlang.com,www.peterlang.net

All rights reserved.

All parts of this publication are protected by copyright.

Any utilisation outside the strict limits of the copyright law, without

the permission of the publisher, is forbidden and liable to prosecution.

This applies in particular to reproductions, translations, microfilming, and storage and processing in electronic retrieval systems.

This publication has been peer reviewed.

Printed in Germany 


\section{Contents}

Acknowledgements ix

BENJAMIN KEATINGE AND MARY PIERSE

Introduction

PART I Seeing France and Ireland

PIERRE JOANNON

The Influence of France on Ireland: Myth or Reality?

MARY PIERSE

Seeing France: Varying Irish Perceptions at the Fin de Siècle

ANNE GOARZIN

Attractive Marginality: Irish Painters in Brittany in the I880s

PART II Constructing the Images

MICHÈLE MILAN

For the People, the Republic and the Nation:

Translating Béranger in Nineteenth-Century Ireland

MICHEL BRUNET

'On the barricades': John Montague's Imaginary Representation of May' 68 in The Pear is Ripe 
KARINE DESLANDES

Ian Paisley: Generating French Perceptions of an Ulster

Loyalist Leader

EAMON MAHER

The Enfant Terrible of French Letters: Michel Houellebecq

PART III The Public Spheres: Interventions and Interpretations

EUGENE O'BRIEN

Towards an Irish Republic: Cultural Critique and an

Alternative Paradigm

BENJAMIN KEATINGE

'So much depends on a TV appearance': Popular and

Performative Aspects of the Poetry of Brendan Kennelly

CONOR FARNAN

Chagall, Balthus, Picasso, Lascaux: French Influences on

Paul Durcan's Engagement with the Irish Public Imagination

PART IV Haute Cuisine and High Society: Ça s’arrose!

DOROTHY CASHMAN

French Boobys and Good English Cooks:

The Relationship with French Culinary Influence in

Eighteenth- and Nineteenth-Century Ireland 
TARA MCCONNELL

Ireland in the Georgian Era: Was There Any Kingdom in Europe So Good a Customer at Bordeaux?

BRIAN MURPHY

Exporting a 'Sense of Place': Establishment of Regional

Gastronomic Identity Beyond National Borders

Notes on Contributors

Index 



\section{Acknowledgements}

The editors are deeply indebted to all who have facilitated the publication of France and Ireland in the Public Imagination. The inspiration owes much to Eugene O'Brien and John McDonagh (Mary Immaculate College, Limerick) who organized an Association for Franco-Irish Studies (AFIS) conference on the theme in 2012 . The realization depended on the essay writers, on the patience of the publishers, and on the financial generosity of AFIS, to all of whom we are very grateful for their contributions. Particular thanks are due to Eamon Maher, General Editor of the Reimagining Ireland series, and to Christabel Scaife at Peter Lang, for their support. As always, the tolerance of colleagues, friends and family has been essential and is much appreciated.

Cork and Skopje, January 2014 



\section{Introduction}

Consideration of France and Ireland 'in the public imagination' demands some brief reflection on what might be considered as belonging to 'the public sphere', as opposed to a putative 'private' or 'personal' space. However, both public and personal may be viewed as irrevocably interlinked and that fusion is admirably illustrated by the Francophile Irishman, James Joyce; as has been suggested by Declan Kiberd, Joyce's masterpiece Ulysses can be read as a modern-day, quasi-Biblical guide to the moral and practical problems of life, which might assist in everyday routines of Learning, Thinking, Walking, Praying, Dying, Eating, Drinking, Reading, Wandering, Singing, Birthing, Parenting, Teaching and Loving. ${ }^{1}$ Clearly, as Joyce's text richly exemplifies, the public sphere is far more than simply a discursive space for political, religious or cultural ideas and debates; rather, it is an integrated, universal realm in which all daily practices are performed. For example, the acts of eating and drinking are, in every culture, imbued with social customs relating to the nature and manner of consumption; even private prayer may take place in a public space of worship. Reading can have varying contexts, from the solitary reader at home to public performance readings of many kinds. Walking or wandering, especially through urban spaces, can be seen as culturally and socially significant actions in which the individual traverses public space and the public sphere. In sum, it can be said that most activities one could name have a social, not to say public, dimension.

But what then is 'the public imagination'? And how does it relate to a putative 'public sphere'? Arguably, 'the public imagination' is a wonderfully

I Declan Kiberd, Ulysses and Us: The Art of Everyday Living (London: Faber and Faber, 2009). These are some of the headings which Kiberd uses as chapter headings in order to discuss the 'everyday' aspects of Ulysses. 
diverse and ever-fluctuating phenomenon that, in different spaces and periods, may cohere, mutate or crumble. Its manifestations be felt as epochmaking interventions in history and culture - or, may merely reverberate briefly in provincial disputes and imaginings. One of our contributors, Michel Brunet, offers this definition: 'By public imagination is meant the popular creative capacity for generating images, symbols and narratives to deal with cultural, social and political realities or personalities; these images and descriptions are those that achieve clear public recognition across space and time, and sometimes lend themselves to myth-making, whether or not they are fully supported by actual facts or deeds. ${ }^{2}$ Brunet makes a useful distinction between 'facts and deeds' and 'myth-making'; clearly, any conception of the public imagination must allow for those instances of misinformation, delusion and impulse which characterize many examples of public discourse in which fear, paranoia, enthusiasm or other emotions may mislead public opinion. While we rely on a responsible media to influence and guide popular debate, it is the inevitable countervailing tendency of individual interest, oppositional and diversionary interjections, and the unpredictability of events, which will ensure that the public imagination will forever remain in flux, and will seldom be unanimous. We should then perhaps acknowledge a certain tension between the public sphere - as conceived by Jürgen Habermas as a forum for rational debate - and the public imagination which encompasses both the potential for myth-making and illusion, as well as that of creativity and inventiveness. In the words of one recent theoretician:

The place and status of imagination is shaped by the position and pressure of an array of contrapuntal concepts such as reason, experience, reality, objectivity, morality and materiality; the imagination has conventionally taken up a location somewhere between the domains of the factual and fictional, the subjective and objective, the real and representational. ${ }^{3}$ of May' 68 in The Pear is Ripe by John Montague'.

3 Stephen Daniels, 'Geographical imagination', Transactions of the Institute of British Geographers 36 (2011): I82. 
So, the public imagination is inevitably the sum of ephemeral and diverse individual and local understandings that are potentially malleable and dirigible, but which inhabit a space between fact and fiction, real and representational. Given the fictional aspects of the public imagination, it is hardly surprising to find that artistic influences become increasingly interesting and important. It is the engagement with these artistic and creative influences on aspects of the public imagination, and on its operation and performance in the public sphere, which intrigue the authors in this book as they engage with the public/private interface and the riches of literary and visual landscapes.

The notions of France and Ireland in image and reality, and as seen from both sides of the Celtic Sea, have offered interesting, sometimes contrasting, depictions over the centuries. Indubitably, the public life of both capitals and countries has been conspicuously connected through the centuries, and the ways in which differing facets of 'the public sphere' have played out in Ireland and France, from the eighteenth to the twenty-first century, feature strongly in this collection of essays. The Franco-Irish relationships have been evolving ones, dependent on a host of historical changes and developments, as both Pierre Joannon and Mary Pierse demonstrate in the two opening chapters. Some of the contributors to this volume comment on Franco-Irish relations in respect of a more formalized understanding of 'the public sphere'. For example, Karine Deslandes explores representations of Ian Paisley in the French media during the Northern Troubles while Michel Brunet examines John Montague's memoir The Pear is Ripe (2008) in which the poet articulates his impressions of May 1968 in Paris. In Deslandes's essay, the public perception of a public figure (Paisley) in France is considered by careful analysis of media reports; in Brunet's essay, the private perceptions (of Montague) of public events in France ('Les événements' of May 1968) are considered in terms of how these private perceptions may or may not cohere with some of the mainstream narratives to emerge from May' 68 . Brunet's essay is thus pivoted on a key dichotomy running through several of these essays: the interface between public and private perceptions. Brunet very expertly shows Montague's complex relation to events as an individual Irish outsider in Paris, but also as a Republican (in both Irish and Gallic senses) who naturally sympathizes with the rebel 
cause; yet, at the same time, and as the movement loses momentum, he adopts a more conservative attitude, even modulating in the direction of a Wordsworthian disillusionment with revolutionary ideals, or towards the detachment of Montague's Montparnasse neighbour, Samuel Beckett.

Other essays collected here deal with individual poets from a public/ private perspective. Two important Irish poets, whose careers seem to be enacted at the interface of public and private roles, are Brendan Kennelly and Paul Durcan, the subject of essays by Benjamin Keatinge and Conor Farnan, respectively. Well known for their public performances, both these poets present a kind of public persona which impinges upon the public imagination, and which mingles a projected version of their private selves with their exterior, public selves; these parallel identities are often difficult to differentiate. Durcan, as a poet, is a risk-taker who dares to confront his readers with the possibility of the outlandishly impossible. As Farnan intuits, Durcan's poetry often adopts a surreal mode in the original sense of that term: surrealism as a supplemental reality or sur-reality, not an unreality. Farnan elucidates some of the visual influences on Durcan's pursuit of the improbable and finds a distinctively Francophone set of influences at work.

In dealing with 'the public sphere' and with the issues which preoccupy 'the public imagination', this volume bears testimony to the historical and cultural variations and transformations which have moulded French and Irish societies from 1700 s to the present. From the country houses of Anglo-Irish gentry, to the salons of nineteenth-century Paris, to the pubs of 1950 s Dublin or even the Irish pubs of contemporary France, the locations of culture and cultural discourse have evolved considerably and will continue to change. The section on 'Haute Cuisine and High Society' illustrates some of this development from the perspective of the gastronomic and oenological traditions in France and Ireland. While France has always been considered the world's greatest culinary nation, the impact of French gastronomic and oenological traditions on Irish traditions of hospitality remains a rich seam of information on cross-cultural exchange which, in this volume, is excavated by Dorothy Cashman and Tara McConnell. Their essays, on the impact of French food and wine culture on eighteenth- and nineteenth-century Ireland, open a window into actual and fictional representations, and illustrate the reciprocal impact of cultural interchange 
between 'Wild Geese' and French merchants in Nantes and Bordeaux some three centuries ago. Likewise, and from a contemporary perspective, the marketing of gastronomic and oenological identity is of crucial economic importance for both France and Ireland and Brian Murphy's essay explores how French food and wine representatives have sought to rebrand the ancient French concept of 'terroir' for the modern marketplace. These essays show that commercial considerations often intermingle with the cultural and social traditions which form the basis for Franco-Irish co-operation, both yesterday and today.

If traditions of hospitality and gastronomy evolve through time and are subject to the vagaries of fashion and the marketplace, the same can also be said for the cultural marketplace where poets, writers, thinkers, artists and musicians ply their trade. In his historical and cultural study Children of the Revolution: The French 1799-1914, Robert Gildea reminds us that literary reputations are subject to historical and cultural fashion, as for example in the sobering case of Henri Beyle, better known as Stendhal:

Born in 1783 , his career was too closely linked to the Napoleonic era to afford him the right contacts [...] when his novel Le Rouge et le noir came out in December 1830 $[\ldots]$ it managed only two editions of 750 copies each and was a resounding flop. ${ }^{4}$

At the other end of the spectrum between 'high' and 'popular' culture is Pierre-Jean de Béranger (1780-I857), a popular and prolific French poet and songwriter whose songs, according to Gildea 'were particular favourites' especially in 'goguettes or drinking clubs's during the Napoleonic era and up to the Bourbon Restoration of I8 14. His songs like 'Le Vieux Drapeau' helped to inspire the July Revolution of 1830 . In fact, the poems and lyrics of Béranger inspired patriotic fervour among his compatriots up to the time of his death in 1857 , after which his reputation sharply declined. A 'Who's Who' of post-Revolutionary France might place Stendhal above Béranger

4 Robert Gildea, Children of the Revolution: The French I799-19I4 (London: Penguin, 2009), 172.

5 Gildea, Children of the Revolution, 48. 
in retrospect, but this was not how contemporaries saw things. An historian of French literature, George Saintsbury, offers the following assessment:

The popularity of Béranger with ordinary readers, both in and out of his own country, has always been immense; but a somewhat singular reluctance to admit his merits has been shown by successive generations of purely literary critics. In France his early contemporaries found fault with him [...] for being a mere chansonnier $[. .$.$] The senti-$ mental school of the Restoration thought him vulgar and unromantic. The Romantics proper disdained his pedestrian and conventional style [...] The neo-Catholics disliked his Voltairianism. The Royalists and the Republicans detested, and detest equally, though from the most opposite sides, his devotion to the Napoleonic legend. Yet Béranger deserves his popularity, and does not deserve the grudging appreciation of critics [...] His versification, careless as it looks, is really studied with a great deal of care and success. As to his matter, only prejudice against his political, religious, and ethical attitude, can obscure the lively wit of his best work [...] Béranger indeed was not in the least a literary poet. But there is room in literature for other than merely literary poets, and among these Béranger will always hold a very high place. ${ }^{6}$

All of this goes to illustrate the multitude of factors (not all of them strictly aesthetic or disinterested) which go into the making of a literary reputation; it also demonstrates the potential disconnect between popular and 'literary' reputation. Clearly, Béranger looms large in any examination of the 'public imagination' in nineteenth-century France even if he is not studied or taught nowadays as a classic of French literature. For these social and cultural reasons, Michèle Milan's essay, 'For the People, the Republic and the Nation: Translating Béranger in Nineteenth-Century Ireland' is an important contribution to this volume.

The issue of literary reputation is also tackled by Eamon Maher in his essay on the controversial French novelist Michel Houellebecq. Sometimes dismissed as a mere pornographer, Houellebecq's novels have nonetheless impacted upon the public imagination both at the popular and 'literary' or 'high' ends of the literary spectrum. There is an under-appreciated Irish dimension to Houellebecq's career; not only did the novelist live in Ireland 
for some years, the plot of his most influential novel Atomised (Les Particules élémentaires, 1998) depends on a cross-cultural comparison between a nominally 'traditional' Irish culture and the supposedly libertine culture of contemporary France. Whatever Houellebecq's long-term merits as a literary novelist, Maher's essay amply demonstrates how the controversies surrounding his life and work have spilled over into the media and have generated a maelstrom of denunciation and defence, all played out publicly in front of the French and Irish peoples.

With the 'public imagination' in mind as the unifying theme of our volume, more than one of our contributors has tackled the issue of public perception and reception of the cultural products of France in Ireland or of Ireland in France. The question of 'Seeing France and Ireland', as our first section is titled, is therefore central to this volume. Not only do Irish and French writers and artists influence one another, the culturally-informed publics of both nations carry with them evolving perceptions of the cultural identity of the other country. The first two essays in this volume, by Pierre Joannon and Mary Pierse, amply demonstrate the generic diversity of this cultural exchange. They take a panoramic view, crossing disciplines and periods, to show the continuity and breadth of cultural influences. Other contributors offer case-studies, for example, of media representation (of the Northern Troubles in France, or of the economic and political crisis of 2008-2009 in Ireland) or individual encounters (for example, by John Montague of political events in May 1968, or Houellebecq's representation of Ireland). Whether the approach is individual or collective, there is always a fluid relationship between representation and reality, between perception and the object of perception, so that our contributors must interrogate not just what is 'seen', but how it is seen and interpreted at a given point in time.

The question of 'seeing' France or Ireland depends, not only on national, but also regional, identity. Both France and Ireland, as nations, are comprised of strongly-articulated regional identities which are only partially subsumed into a national tradition. In France, an excellent example is the strongly autonomous Breton region, thorn in the side of the Jacobin revolutionaries of the 1790 s, and bastion of a more conservative, Catholic and rural identity throughout the nineteenth century. Anne Goarzin demonstrates in her essay on Irish painters in Brittany in the 
I880s that, even if separatist aspirations within Brittany waned after I870, the region held a growing fascination for artists and tourists on account of its rustic traditionalism, and its easier accessibility from Paris thanks to the developments in railway transport. Goarzin postulates that the Irish fascination with Brittany was based partly on a pan-Celtic connection which fostered the artistic exploitation of 'anachronistic yet "richer" social and anthropological themes such as: 'rural landscapes, market, domestic or beach scenes as well as pardon (local pilgrimages) scenes and sitters in local costumes. Citing the example of J.M. Synge in Irish literature as a parallel seeker of rural authenticity, Goarzin argues that these subjects (which were and which remain popular with the public) 'unambiguously displayed the same defiance to the laws of progress and modernity as in literature'. In other words, as France and Ireland modernized, as happened elsewhere in Europe, both countries experienced a surge in nationalist sentiment which sought to locate an authentic, untainted national identity within rural and pre-modern social and regional locales and traditions. In this respect, the efforts of the Irish Revivalists and some of the actors of French regionalist movements in late nineteenth-century France (such as the Union Régionnaliste Bretonne founded in 1898 ) shared the same nostalgia and sentimental attachment to a traditional Petite patrie within a fast-changing Grande patrie, with one identified, somewhat naïvely, in terms of the other.

If some writers and artists sought refuge from modernity in harmonious scenes from rural life, a more discordant engagement with modern life emerged in nineteenth-century French poetry, one which might be said to have cross-cultural parallels in Irish experience. The literary trope of the flâneur, first articulated in Charles Baudelaire's I857 Les Fleurs du mal, shows the flâneur inhabiting the city, but refusing to be subsumed into it; he is not assimilable into bourgeois codes and conventions. Walter Benjamin argues that he (it is an irredeemably gendered concept) approaches the city as "a landscape made of living people"' - such as the destitutes, drunks, 
rag-and-bone men - whose peregrinations are held up as new models of an alienated, urban, artistic consciousness. ${ }^{7}$

The relevance of this nineteenth-century concept of the flâneur for the contemporary twenty-first-century city is tested by Benjamin Keatinge in his chapter on poet and academic Brendan Kennelly. In what ways might one of Dublin's modern denizens be considered a flâneur? Kennelly is often sighted by locals on his long walks around the city and he certainly finds much solace in traversing the cityscapes of Dublin. As Kennelly has remarked:

The walker through Dublin, [...] will discover a place of remarkable elegance as well as scenes of sustained ugliness, drabness and dirt. To explore the endless streets of pre-traffic Dublin early on a summer morning is to experience the variety of this city's character, a character that has survived centuries of misuse and abuse [...] It's easy to see why it was called the second City of Empire: its elegant squares and handsome buildings are a pleasure to the eye. It's easy, too, to understand why so many Dubliners have such pride in, and affection for their city. ${ }^{8}$

In Kennelly's anthology of writings about Dublin - Dublines (from which this quotation is taken) - the editors' selections testify to certain enduring features of the cityscape: 'dear 'aul dirty Dublin' cohabits with the city of elegance and historic charm identified by Kennelly. Features of neighbourliness and Irish hospitality exist seemingly in tandem with the anonymity of the modern metropolis. Nevertheless, the streets of Dublin, arguably, still retain a democratic neighbourliness and conviviality, a truly social urban

7 Walter Benjamin citing Hofmannsthal in Selected Writings II 1927-1934, trans. Rodney Livingstone et al., ed. Michael W. Jennings, Howard Eiland, and Gary Smith (Cambridge, MA: Harvard, 1999), 264. One is reminded of Baudelaire's poem: 'Le Vin des Chiffoniers' or 'The Rag-Picker's Wine' from Fleurs du mal (1868) with the following lines, resonant of a certain vision of the modern city:

On voit un chiffonnier qui vient, hochant la tête,

Butant, et se cognant aux murs comme un poète,

Et, sans prendre souci des mouchards, ses sujets,

Epanche tout son coeur en glorieux projets.

8 Brendan Kennelly, 'Foreword', Dublines, ed. Katie Donovan and Brendan Kennelly (Newcastle: Bloodaxe, I996) iI-I2. 
space that, like the Irish Pub, is still a welcome and welcoming feature of Irish urban and rural life.

However, since the collapse of the Celtic Tiger in 2008 , there has been much soul-searching among critics and commentators about the values that underpin Irish social and political life. As the financial realities of bankruptcy and bailout dawned on the Irish people, there was considerable public anger and public debate about how the Irish financial sector could, effectively, bankrupt the nation by irresponsible lending to property developers. The revelations of political corruption in the Mahon Tribunal and the Moriarty Tribunal reports, together with the Murphy and Ryan reports on clerical child abuse in the Catholic church, and the financial woes facing Ireland, have caused much anxious re-evaluation of the principles and practices of Irish political institutions. Although Irish politicians may not realize it, some of their actions and decisions could be better understood, not on the level of praxis, but on a more theoretical and, indeed, symbolic plane. Eugene O'Brien's analysis of the fall-out from ECB/IMF intervention in the Irish economy and from the decision - taken late at night on 29 September 2008 - to guarantee the Irish banks' losses, exposes a palpable democratic deficit and a lack of accountability at the heart of Irish politics. The novelty of O'Brien's analysis is his deployment of some 'heavy guns' from French post-structuralist theory to shed light on the political mystifications of Ireland's financial plight. Thus, O'Brien presents a Lacanian reading of the outcomes of the various corruption Tribunals while also using the theories of Alain Badiou and Lacan-inspired Slovene philosopher Slavoj Žižek to expose some fundamental flaws in many mainstream interpretations of the financial crisis. When understood through the lens of theoretical interventions by Badiou, Jacques Rancière, Jacques Lacan and Žižek, the French Republican tradition embodied in the original principles of Liberté, égalité, fraternité, may ultimately do more to explain, and ultimately to heal, Ireland's wounded polity than can the bland, pedestrian analyses by journalists and politicians in the mainstream media.

The debates surrounding the financial crisis have achieved one thing: in Ireland, they have forced some national self-assessment and self-evaluation concerning fundamental political and social values. These deliberations and arguments have extended from the pages of newspapers and political 
weeklies, to more searching political and economic studies such as Fintan O'Toole's bestselling Ship of Fools: How Stupidity and Corruption Sank the Celtic Tiger' or Anthony Sweeney's Banana Republic: The Failure of the Irish State and How to Fix It. ${ }^{10}$ In fact, this type of public debate is part of what helps define national identity and nation self-identification. As Benedict Anderson argues:

print-languages laid the bases for national consciousness [...] they created unified fields of exchange and communication below Latin and above the spoken vernaculars [...] Speakers of a huge variety of Frenches, Englishes, or Spanishes [...] became capable of comprehending one another via print and paper [...] These fellow readers, to whom they were connected through print, formed, in their secular, particular, visible invisibility, the embryo of the nationally imagined consciousness. ${ }^{11}$

It is surely true that at times of political crisis, these types of debates and discussions, at the national level (and sometimes international level), are provoked. Retracing the evolution of Irish and French national consciousness substantiates that suggestion: one has only to consider the war of ideas surrounding the French Revolution in 1789 or the 1798 Rebellion in Ireland. Equally, Richard Kearney has elegantly shown that there is by now in Ireland a long tradition of journals and journalism that bridges the gap between politics and culture, broadly conceived. Kearney notes that: 'The journal began to play an important role in Irish life in the early decades of the nineteenth century. Between the Act of Union in 1800 and the rising of 1848 , over 150 periodicals were launched in Ireland. ${ }^{12}$ While many of these were short-lived and narrowly sectarian, it was both in the period closer to national independence in 1922 , and in the whirl of ideas circulating in Revival Ireland, that more such publications incorporated Fintan O'Toole, Ship of Fools: How Stupidity and Corruption Sank the Celtic Tiger (London: Faber and Faber, 2009).

Io Anthony Sweeney, Banana Republic: The Failure of the Irish State and How to Fix It (Dublin: Gill and Macmillan, 2009).

II Benedict Anderson, Imagined Communities (London: Verso, I991), 44.

I2 Richard Kearney, 'Between Politics and Literature: The Irish Cultural Journal', Navigations: Collected Irish Essays 1976-2006 (Dublin: Lilliput Press, 2006), 73. 
genuine public sphere debates, similar to those which have been generated by the demise of the Celtic Tiger. In Kearney's words:

some of Ireland's most formative cultural journals served to inaugurate critical discussion on four of the central ideological standpoints that conjoined in the early decades of [the twentieth century] to found the national philosophy of modern Ireland: I) progressive nationalism (The United Irishman); 2) Gaelic revivalism (An Claidheamh Soluis); 3 ) socialist republicanism (Workers'Republic); 4) Anglo-Irish liberalism (The Irish Statesman). ${ }^{13}$

As Kearney remarks, a similar social and cultural role was played by The Bell in the post-Independence era. The journal of today may be, in the main, accessed through radio or television, but it is cross-fertilized and often dependent upon the printed word, and the cumulative public effect is arguably magnified to an extent that could not be achieved by one journal in the pre-television era.

Despite many cynical voices warning about how new social media may impinge upon serious discussion of social and cultural matters in the public sphere, the evidence of the Celtic Tiger fall-out suggests that a mature capacity for debate exists in Ireland today, as it has in the past, and as it has existed in France at least since the French Revolution. Throughout the twentieth century, France was not bereft of moments of national trauma and national soul-searching; one only needs to consider the battle to defend Verdun in 1916, or the guerre franco-française of the Nazi Occupation, or the Algeria crisis of 1958, as examples of France in the throes of national crisis and debate. The basis of such national crises and debates is a sense of shared national identity which, as Anderson and others ${ }^{14}$ have shown, is partly dependent on the free-flow of information and news within modern, industrialized economies which are regulated within (and across) the borders of independent nation states.

I3 Kearney, 'Between Politics and Literature', Navigations, 82.

I4 See, for example: Ernest Gellner, Nations and Nationalism (Ithaca and London: Cornell University Press, 1983); Eric J. Hobsbawm, Nations and Nationalism Since I780: Programme, Myth, Reality (Cambridge: Cambridge University Press, 1992). 
The public imagination has, historically, participated in the national imaginary or consciousness of France and Ireland, sharing in the same highs and lows, idealism and the defeats at the national level as the individual imaginary does on the individual level. These oscillations are linked both with reality and representation, with the factual flow of history and with the imaginary creations of the artistic realm, so that a relationship between two historic nations like France and Ireland is not one of calculated, rational discourse, but rather, a tempestuous sequence of hopes and fears, victories and defeats which is represented in history and in art and literature. As the essays in this collection demonstrate, in both France and Ireland, the public sphere and the public imagination have generated memorable imagery and have occasioned vigorous debates, all of which have contributed to defining the identities of the two nations and their mutual understandings. Just as the public and private spheres cannot be truly separated, neither can national boundaries refuse or avoid that cultural porousness which enables cross-cultural exchange and interdependence. In their similarities and in their differentiation, the national traditions of both Ireland and France are richly interlinked. This book testifies to the strong cultural bonds and influences which exist, not just between the writers, thinkers, politicians, chefs, poets, painters of these two nations, but also, most powerfully in the imagination and hearts of their peoples. 

PART I

Seeing France and Ireland 



\section{The Influence of France on Ireland: Myth or Reality?}

The question mark punctuating the title of this chapter is not only a sign of prudence on my part, but is also a recognition of the fact that the topic I choose may appear, on closer inspection, incomplete and open to question. Incomplete in that it overlooks the inescapable and overarching influence of a third party, namely the island next door; and questionable in that the influence of one country on another, apart from war, conquest and colonization of course, is extremely difficult to quantify, especially when the country in question is as historically disputed, religiously divided and socially fragmented as Ireland was in the past. This preamble is not meant to deny France's influence on Ireland, but it suggests circumspection in the study of an ambiguous and sometimes ambivalent subject.

Influence presupposes a certain receptiveness based on empathy and/ or shared experience. That we were both true Celts and faithful Catholics was once said to be the bedrock of the empathy between the French and the Irish. Whether we were one, the other, or indeed both, is far from being clearly established. Furthermore, race and religion are not the lenses through which one would nowadays attempt to examine our relationship, past and present.

Of much more weight in the connection between our two countries would be our respective involvement in the great historical struggle for the domination of Europe between reformed England and Catholic France and later on between the British Empire and revolutionary Napoleonic France. These wars connected France and Ireland more closely than anything on record. The writer Hilaire Belloc who was half-French and half-English, as well as a Catholic and a great hibernophile, a dangerous mixture indeed, wrote of these wars: 'They accentuated even if they did not create the Irish consciousness of permanent antagonism to England.' He added that, as a 
consequence 'they certainly accentuated and mainly did create the intense later antagonism of England to Ireland.'

However, the historical empathy between France and Ireland in the context of the ongoing Anglo-French rivalry goes beyond a purely tactical alliance based on the simplistic idea that 'the enemy of my enemy is my friend'. It goes far deeper than that, as the perception of France, either negative or positive, became an integral part of the intellectual construction of British and Irish national identities. It was brilliantly established in 1992 by historian Linda Colley in her compelling study entitled Britons: Forging the nation, I707-1837. As she wrote:

We can plausibly regard Great Britain as an invented nation superimposed, if only for a while, onto much older alignments and loyalties. It was an invention forged above all by war. Time and time again, war with France brought Britons, whether they hailed from Wales or Scotland or England into confrontation with an obviously hostile Other and encouraged them to define themselves collectively against it. They defined themselves as Protestants struggling for survival against the world's foremost Catholic power. They defined themselves against the French as they imagined them to be, superstitious, militarist, decadent and unfree [...]. Imagining the French as their vile opposite, as Hyde to their Jekyll, became a way for Britons - particularly the poorer and less privileged - to contrive for themselves a converse and flattering identity. The French wallowed in superstition: therefore, the British, by contrast, must enjoy true religion. The French were oppressed by a bloated army and by absolute monarchy: consequently, the British were manifestly free. The French tramped through life in wooden shoes, whereas the British - as Adam Smith pointed out were shod in supple leather and, therefore, clearly more prosperous. ${ }^{2}$

You will have noticed that Professor Colley did not include the Irish in the list of people coming together under the name of Britons, for which francophobia was such a significant element in terms of national definition. This is because for many Irish, but not all it is fair to say, the French were more akin to the Self than the Other. No one has expressed it better than

Richard Hayes, Ireland and Irishmen in the French Revolution, with a preface by Hilaire Belloc (London: Ernest Benn, 1932), viii.

2 Linda Colley, Britons. Forging the Nation $1707-1837$ (New Haven and London: Yale University Press, 1992), 5; 368. 
William Lecky, the famous nineteenth-century historian who, even though he was a staunch unionist, wrote at the outbreak of the Franco-Prussian war of I870: 'In Ireland, we are passionately French, partly because we think ourselves rather like the French, partly because of the Irish Brigade which served under France, and partly because the English take the other side.'

Needless to say, this affinity between Ireland and France led to many contacts and exchanges, so much so that for the Irish to ponder on France and the French was often to undertake a voyage of self-discovery. I recently came across a forgotten novel by Shane Leslie entitled Doomsland. In 1923, the year of its publication, this book was hailed by the Evening Standard as 'the most complete emotional survey of the Ireland of our time'. Richard, the main character, discovers his Irish roots in Paris of all places and, as Shane Leslie writes,

In these days, he wandered about Paris in the track of Irish exiles. Paris cemeteries were full of Irish graves, her archives were choked with Irish plots and documents. The Irish swarmed in French history. In old colleges and behind crumbling walls priests, soldiers, and secret agents had conspired. Through eighteenth century Paris passed the Wild Geese of the Irish Brigade. In Notre Dame knelt the victors of Fontenoy. From the Irish College priests passed to and fro between the two countries. It was an Irish abbé who remembered the right words to cry to Louis XVI at his execution, and an Irish physician accompanied Napoleon to St Helena. Here Wolfe Tone met the First Consul. Here Humbert and Hoche received orders for their invasion of Ireland. And the gorgeous sunset behind the mighty Arc de Triomphe goldenised the ashes of the anonymous myriads of Irish dead. ${ }^{4}$

Having fixed the boundaries of Irish francophilia and British francophobia within the parameters of identity building in both islands of the archipelago, let us turn our thoughts to the French influence on Ireland. Throughout history, we can see it at work in religious matters, in politics and notably on the birth of Irish republicanism via the United Irishmen,

A memoir of the Rt Hon. W.E.H. Lecky by his wife, London 1909. Quoted in Alfred Duquet, Ireland and France (Dublin and London: Maunsel and Co., 1916), xxx.

Shane Leslie, Doomsland (London: Chatto and Windus, 1923), 246. 
and in literature, and last but not least, in our cooperation in the building of Europe during the last forty-one years.

On the survival of the Catholic faith in Ireland, the influence of France cannot be underestimated. At the time of the Penal Laws, Irish would-be clerics, unable to gain religious education in Ireland, travelled to France in order to pursue their studies in French catholic institutions and, in a chain of Irish colleges protected and endowed by French kings and gentry. Irish seminaries were to be found in Paris, Toulouse, Bordeaux and Nantes as well as in Douai, Lille and Bourges. Founded in 1769 , the Irish College which still stands in the rue des Irlandais, behind the Panthéon, in Paris, was one of the most important, if not the most important, source of Irish ordinations in Europe. It sent no less than fifty bishops to the Irish Catholic church. When the revolution broke out, there were 478 Irish ecclesiastical students on the continent, of whom 348 (nearly three quarters) were receiving their education in France.

According to Lecky, no subsequent generation of Irish priests have left so good a reputation as this class of Frenchified clerics. As he wrote:

They grew up at a time when Catholicism throughout Europe was unusually temperate, and they brought with them a foreign culture and a foreign grace, which did much to embellish Irish life. Their earlier prejudices were corrected and mitigated by foreign travel. They had sometimes mixed with a society far more cultivated than an Irish protestant country clergyman was likely to meet, and they came to their ministry at a mature age, and with a real and varied knowledge of the world. If they produced little or nothing of lasting value in theology or literature, they had at least the manners and feelings of cultivated gentlemen [...] and they were saved by their position from the chief vices and temptations of their class upon the continent. The leaders of a poor and unendowed church, which was appealing to the principles of religious liberty in order to obtain political enfranchisement, were not likely to profess the maxims of persecutors or to live the lives of epicureans.

In order to put an end to the French influence in religious affairs while, at the same time, exploiting the situation created by the closing of the Irish

$5 \quad$ W.E.H. Lecky, History of Ireland in the eighteenth century Vol. 3 (London: Longman's Green and Co., 1913), 354-5. 
colleges and seminaries in France, the British government took the decision to establish and endow a college 'for the better education of persons professing the Popish or Roman Catholic religion'. Even though the new seminary in Maynooth counted among its professors several French refugees, the training at home of the Irish priesthood from 1795 onwards was the death-knell of French influence on Irish church affairs. 'The chain hitherto binding Ireland and France was broken', said Hilaire Belloc. ${ }^{6}$ The persistent and often violent struggle between Church and State in nineteenth-century France alienated Catholic Ireland for good and made it impossible to renew the tie ever since.

Having for ever lost its influence over religion, France was quick to regain it in the field of politics and, to be more precise, in the realm of political philosophy. The soft breeze of liberty coming from America turned into a tornado when the French Revolution erupted all of a sudden in 1789 . That this seismic upheaval was to have immense repercussions in Ireland is hardly surprising. A substantial number of Irish people had always looked in the direction of France for inspiration, support or personal advancement. Before turning to the New World, it was in the Kingdom of France that the great bulk of Irish migrants settled throughout the seventeenth and eighteenth centuries. Furthermore, as was pointed out by Edmund Burke's son, Richard: 'Many of the causes which produced the French Revolution exist(ed) in Ireland: the landed interest separated from the commercial, the gentry from the peasantry, the civil and ecclesiastical establishments from the people."

Ireland's response to the first episodes of the French Revolution was enthusiastic, bewildered and misconceived. The Anglo-Irish members of Grattan's Parliament rejoiced in the fact that the French had, at long last, acquired the freedom that the English had been enjoying since the Glorious Revolution of $\mathrm{I} 688$, and from which the Irish had benefited since the achievement of the so-called parliamentary independence of 1782 . For the radical enlightened dissenters of Ulster, mostly Presbyterians, the French

6 Hayes, Ireland and Irishmen in the French Revolution, xi.

7 Hayes, 7. 
Revolution marked the triumph of their egalitarian aspirations not only against the authoritarianism of Church and State and the social privileges of the aristocratic landed gentry but also against what they saw as the tyranny and obscurantism of the Catholic Church. For the Catholic weavers, labourers and tenant farmers who had taken the oath of the Defender secret societies, the French revolution was reinstating France as the ally and avenger of the Catholics. Seeking French help right from the beginning, their objectives were simple: 'to knock the Protestants on the head, and take their place.8 The aristocratic worshippers of the French Revolution soon realized that Danton and Robespierre were not John Locke or William Molyneux in French garb; they quickly fell in line behind the great Edmund Burke, undoubtedly the most brilliant, articulate and forceful opponent of the new order taking root on the Continent.

As a result, the development of Irish republicanism produced an explosive blend of the cosmopolitan inclusive egalitarianism of the United Irishmen with the sectarian exclusive nationalism of the Defenders. It was the Right of Man against the Right of the People or, if you prefer, 'Liberté, Egalité, Fraternité' versus 'Ourselves Alone.'This dialectical tension between two opposite trends has been a characteristic of Irish republicanism down to the present day. As such, however, it should be acknowledged that it has been very similar to its foreign models, and Richard Kearney is right in saying that 'there is a fundamental paradox coiled at the heart of modern republicanism, in France, America and Ireland. On the one hand, republicanism has promoted an enlightened universalism of world citizens. On the other, it has permitted a separatist nationalism which subordinates the universal rights of the citizen to the right of the nation-state."

In order to separate the wheat from the chaff, if such a purifying exercise is deemed possible without falling into the trap of counter-factual (New Haven and London: Yale University Press 1982), 42. People and the Rights of Man' in Ireland and France. A Bountiful Friendship, ed. Barbara Hayley and Christopher Murray (Gerrards Cross: Colin Smythe, 1992), 40-I. 
history, one should revisit Wolfe Tone's vision of a non-sectarian, democratic, inclusive Ireland. He stated his motives which are still as valid today as they were then: 'To unite the whole people of Ireland, to abolish the memory of all past dissensions, and to substitute the common name of Irishman in place of the denominations of Protestant, Catholic and Dissenter. ${ }^{10}$

This vision, so similar to the principles enunciated in the two French declarations of the Rights of Man of 1789 and 1793 , led Tone to commit himself to the establishment of an Irish Republic, sister of the French Republic, which would transcend and obliterate the island's tribal divisions and confessional differences. He believed that it would not be feasible without French military assistance and he travelled to Paris to seek the support of the Directoire. Uncertain of his role and of his chances of success, lost in a foreign capital city far away from home, family and friends, he could have carved for himself the image of a misguided dreamer, a self-appointed adventurer or a petty revolutionary agitator. Because of his cheerfulness, his idealism, his perseverance and his partial success crowned by defeat and death, he is now remembered as the unofficial ambassador of the United Irishman movement, the founding father of Irish republicanism, and the first hero of the modern democratic era. For me, he is also the author of compelling diaries revealing his love of France and the French people, a close friend of Hoche, a distinguished French officer and a 'Français par le sang versé, a Frenchman by blood spilt for France, as he took his own life in order that his French officer's uniform would not be sullied by the hangman's noose. Whenever I am asked to name the best intercessor between our two countries, invariably the noble figure of Theobald Wolfe Tone springs to mind.

Following in his footsteps, the Young Irelanders made their pilgrimage to revolutionary Paris in the spring of $\mathrm{I} 848$ from whence they did not return totally empty-handed. Indeed, as was commemorated at Easter 2012, Edward Hollywood, a silk weaver from the Liberties, bore the famous

Io Theobald Wolfe Tone, The Life of Theobald Wolfe Tone, ed. William Theobald Wolfe Tone (Washington, 1831), 62. 
green, white and orange flag back to Ireland. Modelled on the French tricolour, it was given to him by the Provisional Government of France. It was displayed on the I5 April 1848 in the Music Hall of Abbey Street in Dublin. John Mitchel's paper, The United Irishman, reported Thomas Francis Meagher's speech:

From Paris, the gay and gallant city of the tri-colour and the barricade, this flag has been proudly borne. I present it to my native land, and I trust that the old country will not refuse this symbol of a new life from one of her youngest children. I need not explain its meaning. The quick and passionate intellect of the generation now springing into arms will catch it at a glance. The White in the centre signifies a lasting truce between the 'Orange' and the 'Green', and I trust that beneath its folds the hands of the Irish Protestant and the Irish Catholic may be clasped in generous and heroic brotherhood. ${ }^{11}$

Some twenty two years later, France was still present in the hearts and minds of the Irish people, if we are to believe G.K. Chesterton who wrote in his Irish Impressions:

Let's always keep in mind a historical fact I have mentioned already: the reality of the old Franco-Irish entente. It lingers alive in Ireland, and especially the most Irish parts of Ireland. In the fiercely Fenian city of Cork, walking round the Young Ireland monument that seems to give revolt the majesty of an institution, a man told me that German bands had been hooted and pelted in those streets out of an indignant memory of 1870 . And an eminent scholar in the same town, referring to the events of the same 'terrible year', said to me: 'In 1870 Ireland sympathised with France and England with Germany, and, as usual, Ireland was right., ${ }^{\text {,12 }}$

It should also be noted that the French influence was present in the first Dáil when the declaration of independence was not only read in Irish and English but also, significantly, in French, as French was considered by many of the legislators to be the idiom of liberty. Several leaders of the Irish Free State were of the opinion that closer relations with France might have been

II Michael Cavanagh, Memoirs of Gen. Thomas Francis Meagher (Worcester, Mass.: The Messenger Press, I892), I63-4. 
one of the best ways to implement the Collins policy of exercising freedom to achieve freedom for Ireland. In his splendid biography Joseph Walshe and Irish Foreign Policy 1922-1946, Aengus Nolan has revealed that 'at this time, some in Ireland hoped that Irish foreign policy would turn from the Commonwealth and move more towards France. One suggestion was that a Franco-Irish entente be established by taking advantage of the growing disparity and disagreement between Britain and France at that time. It was estimated that France was the strongest of the European continental powers, and for that reason, they should be played up to in every possible way.' ${ }^{13}$

However, if the old Franco-Irish entente was to be resuscitated, it was not in the realm of politics, but in the richer fields of literature. The journey to Paris in search of models or inspiration was, for many Irish writers, a deliberate move to emancipate themselves from Albion while at the same time redefining their identity. Brian Fallon put this cultural fascination in its proper historical context when he said:

\begin{abstract}
It was not only admiration for French culture, French political structures and French thought which inclined the Irish intelligentsia towards Francophilia. France offered, in effect, an alternative to English domination or at least a corrective to it. France was republican while Great Britain was monarchist, and the fact that both had colonial empires was often conveniently overlooked in this Irish exaltation of France as the home of liberty, equality and fraternity. France was also seen as the land of artistic modernism and innovation, while English culture - as exemplified by a writer such as Galsworthy - was often considered stodgy, inward-looking and insular. ${ }^{14}$
\end{abstract}

Sydney Owenson, alias Lady Morgan, who was to Ireland what Madame de Staël was to France, visited Paris on several occasions after the fall of Napoleon. In June i817, she published a two-volume vivid description of French society entitled France. The book was extremely successful but the Gallic influence over its author was considered very distasteful by the British Tory press in so far as she was making comparisons with her own

I3 Aengus Nolan, Joseph Walsh. Irish Foreign Policy 1922-1946 (Cork: Mercier Press, 2008), 25-6; 345, note 37 .

I4 Brian Fallon, An Age of Innocence: Irish Culture 1930-1960 (Dublin: Gill and Macmillan, I998), I24. 
country which were highly critical of the state of affairs in Ireland. She was accused of irreligion, Jacobinism, indecency, vanity and ignorance, a demonstration of the extent to which she had become more French than the French themselves. These perceived vices were then and still are very often used as a term of abuse that we, French, are receiving by the bucketful from the English gutter press. 'Like a cook with a heavy hand on the garlic', she was also criticized for using too many French expressions in her writing and in her conversation. ${ }^{15}$

George Moore, who came to live in Paris in 1873 , wanted to be a painter. However, under the influence of Théophile Gautier and Baudelaire, he was to start the process by which he would instead become a man of letters. He met Mallarmé and Manet who painted his portrait, and Zola who impressed him greatly. Many years later, Yeats would write rather maliciously: 'A revolutionary in revolt against the ignorant Catholicism of Mayo, (Moore) chose for master Zola as another might have chosen Karl Marx. ${ }^{, 16}$ Living the life of a typical French man of letters, Moore did not hesitate for a moment to claim that France was 'his own country', and French 'the language that should have been mine. ${ }^{17}$ On another occasion, he confessed: 'I am full of France', so full that he was never to forget this early experience that was to be frequently renewed throughout his life. ${ }^{18}$ Although he was never to lose sight of Ireland, his heart was definitely elsewhere. He had fallen in love with Paris at a tender age. France was the country he had elected for himself and he was mesmerized by its cultural and artistic life. The explanation he gives is the typical Irish discourse about identity, reconstruction and the desire to turn one's back upon England: 'I had tried with all the strength of my heart and soul to identify myself with that which surrounded me, to get rid of my race and language, to recreate

I5 Mary Campbell, Lady Morgan: The Life and Times of Sidney Owenson (London: Pandora, 1988), 134.

W.B. Yeats, Autobiographies. Memories and Reflections (London: Bracken Books, I995), 405 .

I7 George Moore, Hail and Farewell (Gerrards Cross: Colin Smythe, 1976), 257.

I8 Georges-Paul Collet, George Moore et la France (Genève: Librairie Droz, I957), i8. 
myself, so to speak, in the bosom of a new nationality, by borrowing its ideal, its way of life, its workings of the mind. I had succeeded marvellously.' ${ }^{19}$

Oscar Wilde also loved France dearly, so much so that he once described himself as 'Irlandais de race' but 'Français de sympathie. ${ }^{20} \mathrm{He}$ spoke French fluently and was adamant that 'every artist should know French, and every gentleman. ${ }^{21}$ Like Moore, he had rubbed shoulders with Mallarmé, Zola, Degas and Edmond de Goncourt. The Picture of Dorian Gray was clearly influenced by Joris Karl Huysmans, the author of $A$ Rebours, masterpiece of the aesthetic and decadent movement. Wilde wrote his play Salomé directly in French and, when it was banned in London, he considered leaving England and becoming a French citizen. ${ }^{22}$ The English, like Lady Bracknell, were not amused, and in order to poke fun at him, Punch, in its issue of 9 July I 892 , published a caricature of Wilde in the uniform of a French trooper, which entitles him, in my opinion, to be called the last of the Wild Geese, with or without the final 'e... ${ }^{23}$ France for Wilde was the land of artistic and sexual freedom as opposed to the hypocrisy and philistinism of England. After his release from Reading jail, he crossed the channel never to return. He finally settled in Paris where on his death he was buried in the Père Lachaise cemetery. As one critic said aptly: 'France was the adoptive, encouraging and forgiving mother who welcomed him at the start of his literary career, embraced him during his years of success, and succoured him after his downfall. ${ }^{24}$

William Butler Yeats resided in Paris in the I89os; he visited the downtrodden poet Paul Verlaine in his humble lodgings of the Rue Saint Jacques.

I9 Collet, George Moore et la France, i8.

20 Oscar Wilde, The Complete Letters of Oscar Wilde, ed. Merlin Holland and Rupert Hart (London: Fourth Estate, 2000), 505.

2I Holland and Hart, IIO2.

22 Holland and Hart, $53 \mathrm{I}$.

23 A reproduction of this caricature can be found in the Album Oscar Wilde (Paris: Gallimard, 1996), I5I.

24 Anne Markey, 'French Culture and Oscar Wilde's Fairy Tales: an unexplored interlink with neglected works of art' in Reinventing Ireland Through a French Prism, ed. Eamon Maher, Eugene O’Brien and Grace Neville (Frankfurt: Peter Lang, 2007), I32. 
In the autumn of 1896 , whilst staying at the Hotel Corneille, near the Odéon, he met John Millington Synge who was living on the attic floor of the hotel, and was in the grip of a depression. Without guessing what a genius he would turn out to be, Yeats urged him to go to the Aran Islands to 'find a life that had never been expressed in literature, instead of a life where all had been expressed.'. ${ }^{25}$ Yeats himself was greatly influenced by the French symbolist movement: he was indeed very fond of the poetry of Mallarmé and of the plays of Villiers de l'Isle Adam. But, apart from these strong literary influences, Yeats had another reason to be attracted to France in general and to Paris in particular. He was in love with the beautiful and more-than-reluctant Maud Gonne who was a true 'Parisienne' as well as a reckless Irish nationalist. Yeats was hoping, against all odds, to induce her to respond favourably to his unrequited passion. In 1908 , in a small house in Passy, Maud Gonne gave him at last what, for nineteen long years, he had been longing. It was to be their one and only night together. This is a perfect demonstration that the influence of France can take many forms and that the scented air of Paris has an exhilarating effect not often to be found in dear old dirty Dublin. France gave Yeats not only love, but death as well. In 1939, the great Irish poet died at the Pension Idéal Séjour in Cap Martin on the French Riviera. Roy Foster, author of an outstanding biography of Yeats, said recently that his passing away on French soil was appropriate, because 'part of the pattern of his life is a linkage between Irish identity and an intellectual and aesthetic affinity with Europe, particularly France. ${ }^{26}$

James Joyce, the other giant of Irish literature, owes Paris the recognition of his genius as well as the publication in English and in French of his magnum opus Ulysses. Burned in America, condemned in England, seized in Ireland, Ulysses was hailed as a masterpiece by influential French writers and critics like Valery Larbaud, Louis Gillet and Philippe Soupault. France was, for a time, the only Joycean stronghold against the philistinism of the outside word. We may say without exaggeration that, in that 
particular instance, Paris saved Dublin. And we may surmise that Joyce was thinking of France when he ascribed to himself the task to Europeanize Ireland and Hibernicize Europe, a mission that is well advanced but far from complete today!

Many other Irish writers and poets came, or turned their attention, to France to find new ways of expressing their inner self. James Stephens lived in Paris before the First World War. He was a voracious reader of Honoré de Balzac and Anatole France. The last poem he set his eyes upon, on Christmas day 1950, on the eve of his death, was La Fontaine's fable 'La Mort et le Mourant', a perfect lesson in stoicism. As an Irish writer, Brian Moore, felt a special need to establish some links with France: 'It was a foreign country where I felt at home' and he recalled:

I had lived on the left bank of Paris in the Fifties and Sixties, caught up in the AngloSaxon nostalgia for the Twenties when Joyce, Beckett, Hemingway et al., found in France a spiritual home away from home. Wasn't it Joyce who told Ford Madox Ford to put down his profession as 'romancier', French for novelist, when he signed in at a hotel because France was the one country where they took literary men seriously? ${ }^{27}$

The writer John Broderick, author of The Pilgrimage (196I) and The Waking of Willie Ryan (1965) was clearly influenced by François Mauriac. A critic has even suggested that, in these novels, "he was attempting to reinvent himself as a French-style Catholic novelist. ${ }^{28}$ Among poets, Brendan Kennelly has acknowledged four major influences on his large corpus of poetry, novels, plays and criticism: one is Irish, Kavanagh; one is American, Ginsberg; and two are French, Baudelaire and Rimbaud. John Montague, who currently lives half of the year in Schull in West Cork and half of the year in Nice in the South of France, has claimed to have 'established a fertile dialogue between (his) old and new worlds, Ireland and France.'. The same can be said of Derek Mahon who has produced remarkable translations of

27 Brian Moore, 'Patrick Rafroidi: before and after' in Hayley and Murray, Ireland and France. A Bountiful Friendship, 5-6.

28 Madeline Kingston, Something in the Head: The Life and Work of John Broderick (Dublin: Lilliput Press, 2004), I22.

John Montague, Company: A Chosen Life (London: Duckworth, 2001), I2I. 
Molière, Nerval, Valéry and Jaccottet. 'Mahon's francophilia, writes Terence Brown, one of the most perceptive contemporary critics and scholars, 'is more than a simple regard for the qualities of French life and letters [...]. Rather it is an element in an imagination that has always been tantalized by the nature of alternative modes of consciousness and feeling. ${ }^{30}$ More precisely, Terence Brown adds that France has been for Mahon an imaginative escape route from the tedium of the provincial and the fixity of an inherited identity. ${ }^{31}$

However, in terms of soul-searching under French influence and reconstruction of oneself far away from Albion's grasp, I can find no better example than Samuel Beckett. To a Frenchman who once asked him if he was English, he is reputed to have answered 'Au contraire', on the contrary, a very explicit response, albeit a minimalist one. The counterpoint of English being obviously French, Samuel Beckett not only decided to live in France, he also shared the fate of the French people during the war, played his part in the Résistance for which he was awarded the Croix de Guerre, and ended up writing his novels and plays directly in French. Whilst avidly interested in what was going on in Ireland, very much like James Joyce, he is the first example of a unique species: a Hiberno-French writer who can equally be claimed by the Irish and by the French as 'one of our own'. The fact that this giant of letters changed the face of modern writing serves only to prove that the Franco-Irish literary symbiosis is a remarkable weapon of intellectual superiority which should be encouraged by the governments of our respective countries.

But, as we say in France, 'une hirondelle ne fait pas le printemps', one swallow doesn't make a summer, and the success of the literary connection must not hide the fact that since the beginning of the twentieth century and until the early seventies, France lost what was left of the influence it once had on Ireland. As the ubiquitous Hilaire Belloc asked in 1932: 
Whether that ancient attachment between Ireland and France will revive, the future only can show; it will depend in part upon the settlement of the French religious quarrel, in part upon the new orientation of international forces, more perhaps upon new factors in the culture of the West which we are only now beginning dimly to perceive. $^{32}$

Belloc would be amazed to see that the French religious quarrel has been settled for good whereas the Irish are suddenly finding fault with their own religious institutions. But he was right in anticipating a new orientation of international forces. Europe has seen the binding together of twenty seven countries of the old Continent. And since I January 1973, Ireland has been a member of that federation of nations.

It was to be expected that Ireland would find France at her side as soon as the imperatives of solidarity and mutual interest would take precedence over the undisturbed solitude of isolationism. As a new member of the then European Economic Community, Ireland was destined to follow the lead of the country with which she felt the greatest affinity. To prove this point, I shall quote the testimony which Michael O'Kennedy gave me in a letter dated is January 1999:

In November 1972 I was appointed to the Cabinet by the Taoiseach Jack Lynch in succession to Paddy Hillery, Minister for External Affairs, who was about to take up appointment as Commissioner of the European Economic Community. President Eamon de Valera, who was soon to retire after i 4 years service as Uachtarán na hÉireann invited Paddy Hillery and myself for an informal luncheon in Áras an Uachtaráin to say farewell to Paddy who had been a Constituency Representative for Clare with President de Valera in the late i95os.

Because of their close relationship, the occasion was a very informal and relaxed affair in which their personal recollections of friendships and events were exchanged with amusement and affection. At the end of the lunch de Valera turned directly to Paddy and said words to this effect: You don't mind, Paddy, if I give you a last bit of advice before you go. We have been cut off from Europe for a long time now and you are the first Irishman to have the honour of taking on this very important role as Commissioner in the European Community. I am sure it will be a new and sometimes 
strange experience for you. But remember this - stay close to the French - they were always our friends over the years and if you follow them you won't go too far wrong.

Paddy Hillery obviously took Dev's advice on board and developed a very deep and personal relationship with François Ortoli, President of the Commission, in which Paddy himself served with distinction as Vice-president. He often quoted Dev's advice to me over the years and I was privileged myself subsequently to further develop that friendship with Ortoli who was Vice-president of the Commission in which I served with, amongst other French colleagues, Claude Cheysson and Edgar Pisani. I think Dev and his friend General de Gaulle would be very happy to know that Paddy Hillery not only listened to Dev's advice but applied it very effectively in his own inimitable, if self-effacing style. ${ }^{33}$

This was sound advice indeed whilst the Irish representatives were finding their feet in Brussels. It is less evident now since Irish civil servants are now so familiar with the corridors of powers in Europe that they could give a lesson or two to newcomers in search of the right contacts and the right procedures to follow.

France and Ireland are still very close but it is less a matter of influence of the former on the latter, and more a defence and promotion of mutual interests. When there is a divergence, we generally find Ireland in pragmatic alliance on a case by case basis. I will not go into details which are well known to all. Suffice it to say that the areas of common interest which sustain a real partnership between our two countries are numerous and fundamental. We saw eye to eye in the promotion of a cohesion policy in favour of the peripheral regions of Europe. We are dedicated to the defence of the Common Agricultural Policy (CAP). We are both very keen to develop a European Security and Defence Policy (ESDP). For any operations however, Ireland's has put three conditions to her involvement, the famous triple lock: the authorization of the operation by the Security Council of the General Assembly of the United Nations, the agreement of the Irish government, and the approval of Dàil Éireann, in accordance with Irish law. The EU peace enforcement mission in Chad known as EUFOR was thus approved and placed under the command of an Irish officer, Lieutenant-General Pat Nash. It succeeded in providing security 
along the Chad - Sudan frontier. France and Ireland have in common their membership of the euro-zone, and to a greater or lesser extent, both are experiencing the detrimental effect of the economic tsunami which has rocked all the boats in Europe and further afield.

Au contraire, to quote Beckett, we are not on the same wave length when it comes to tax harmonization, or justice and internal affairs (Ireland is not in the Schengen area), or reliance on nuclear power as a source of energy, or the entry of Turkey into the European Union, etc., etc. It occurs to me though that our agreements outweigh our disagreements. Old friends learn to live with each other's foibles. After all, the European Union is not a military barracks where everybody has to obey standing orders. The most important thing is to know, respect and understand each other. Thanks to the European Union we have revived and must take care never to let vanish the ancient attachment between France and Ireland.

I was thrilled to read President Michael D. Higgins's address to the third Thomas Flanagan lecture at the American Irish Historical Society of New York on I May 2012. This was for three reasons: first of all because Thomas Flanagan, as you will recall, is the author of The Year of the French, a superb evocation of the ramblings of General Humbert's little army in the Mayo bogs. Secondly, it was for what the Irish President had to say: 'I would like my presidency to be remembered as a presidency of ideas [...] Ireland should never be anti-intellectual. ${ }^{34}$ Well, as it happens, France has never been short of ideas. It was once said by a French president that 'France has no oil but plenty of ideas.' We might share them with you. As for the intellectuals, who are plentiful in St Germain des Prés, we could spare a few and let you have them at a very reasonable price. Last but not least, I strongly believe that the desire, expressed by President Michael D. Higgins, to build the foundation of a new Republic should bring you closer to your roots embedded in the United Irishmen's political philosophy and, as a consequence, nearer to the Franco-Irish Entente that existed at the time.

Allow me to hide behind the massive corpulence of G.K. Chesterton who will conclude in my name: 'If the Irish were what Cromwell thought 
they were, they might well confine their attention to hell and Connaught, and have no sympathy to spare for France. But if the Irish are what Wolfe Tone thought they were, they must be interested in France, as he was interested in France. ${ }^{35} \mathrm{~W}$ ith these fine sentiments, I rest my case. 


\section{Seeing France: \\ Varying Irish Perceptions at the Fin de Siecle}

In 1900 , and in the decades immediately surrounding that year, the unresolved and sharply-contested states of Ireland and 'Irishness' can only have resulted in marked diversity of opinion and influence, and in a multiplicity, complexity and fluidity of viewpoints on any subject. Within the various societal groupings in a population of 4.5 million people, perceptions of France and the French must perforce be equally varied and numerous. Through focus on a selection of disparate elements that fed contemporary perceptions, this essay will suggest that it would be simplistic and erroneous to accept reductive summaries or over-simplified versions of attitudes when surveying Irish views of France at the fin de siecle.

An important consideration in treating the notion of perception is to acknowledge its different stages of construction and processing: its shaping by learning, by memory, and by expectation, whether on the part of individuals or of communities; the initial and subsequent organization and interpretation of information derived from all of those sources. Since much of that assimilation and formation occurs outside conscious awareness, the ultimate standpoints may not always depend on logic, nor might they, at all times, be neatly and easily verbalized. Hence, to identify actual or possible versions of Irish verdicts concerning France in the period around the fin de siècle, a wide selection of potential influences must be considered in the search for the diverse elements that fashion such stances. Those ingredients will be found in popular history, in the education programmes of the period, in the pronouncements of politicians and clergy, and in the multiple messages delivered by the mass media. Assessments will also be shaped and inflected by novel and short story, by song and ballad, by theatre and even by the visual imagery circulating at the time. Although those 
constituents will blend and intermesh to varying degrees, examination of the separate aspects provides interesting insights into the complexity of an ultimate mixture, and into how arbitrary can be the multiple phenomena that go to create public imaginations.

Some key historical milestones that were most remembered around the turn of the twentieth century would include the Act of Union, Catholic Emancipation, the great Famines, and then the Young Ireland rebellion of 1848 , that year of revolutions in Europe. For the Irish, one of the many French connections is illustrative of the sometimes random impact of story and symbol and it concerns two Young Ireland leaders, William Smith O'Brien and Thomas Francis Meagher, who travelled to Paris to celebrate and congratulate those leading the new French Republic. Meagher returned to Ireland with a woven tricolour flag of green, white and orange, allegedly made by French women who wished them well in their aim of winning Irish independence. The fact that different stories surround that flag ${ }^{1}$ underlines the mutability of memory and anecdote but, more vitally, the origin and inspiration served both to confirm, and to further reinforce, the existence of certain Hiberno-French links - the kind of connection that was valued, and determinedly adhered to, by some right up to the turn of the century, and equally condemned and deplored by others. The Young Irelanders obviously saw Republican France as a haven: after the failed rebellion, James Stephens and John O’Mahony fled there to avoid arrest. In a pattern that would be oft repeated, they supported themselves in Paris by teaching and translation work while they planned their later moves.

Subsequent noteworthy phases in Irish history could be identified as the 1867 Fenian rising, the Land War, and the rise and demise of Parnell. However, while those successive periods are eventful and traumatic, any links to France were not as apparent to the public at large at the fin de siecle, and were accordingly less evident in contemporary public discourse. Yet even then, although sometimes in subterranean consciousness, there existed

I See Pierre Joannon, 'The Influence of France on Ireland: Myth or Reality?', in this volume. 
Irish visions of France which were firmly linked to the French willingness to send its entire Atlantic fleet under Hoche to Bantry Bay in $1796{ }^{2}$ and then to General Humbert's arrival in Killala in 1798 to help the United Irishmen. ${ }^{3}$ For decades, those memories were mixed and blended with recollections of connections to the Wild Geese and to the Irish Brigades. Despite memories of a series of dashed expectations for Irish autonomy, hopes were never extinguished, so that in the last decades of the nineteenth century, with the approach of the centenary of the United Irishmen's rebellion in the 'Year of Liberty', discussion of Irish-French relations would re-emerge and assume even greater prominence in the public consciousness. As debate came right out into the open, it was inevitably coloured and inflected by those many and diverse cultural memories.

While the perspectives and therefore the perceptions were various, it is very clear that quite a few key notions were very deeply embedded, ${ }^{4}$ each relating to degrees of sympathy with France and the French. When M. Louis François Paul-Dubois visited Murrisk Abbey at the turn of the century, he met an old man whom he described as a peasant, a man who sympathized with him on the French defeat some thirty years earlier in I870, regarded it as a calamity as though to his own family and said 'we know all about it.' ${ }^{5}$ Clearly, this degree of memory depends on a voluntary and rather keen interest in French affairs, an interest that betrays investment in French welfare, and suggests that, for that man and his community and their like, French and Irish wellbeing would have been regarded as somewhat interdependent. ${ }^{6}$ It must be recorded that it was not just the 'peasants' who cared about the aftermath and effects of the Franco-Prussian

Thirty-five ships and between 12,000 and 20,000 troops actually arrived but did not succeed in landing.

3 This time, the assistance was much smaller; three frigates and $\mathrm{I}, 000$ troops arrived.

4 See, in particular, Joannon, 'The Influence of France on Ireland: Myth or Reality?'

5 L. Paul-Dubois, Contemporary Ireland (Dublin: Maunsel and Company Ltd, I908), I 82 .

6 T.M. Kettle's introduction to Contemporary Ireland notes the identification of history and temperament as at the root of Franco-Irish closeness, v. 
conflict: money collected at the weekly cultural lectures in Trinity College in I87I went to the 'Mansion House Fund for Relief of Distressed French peasantry' in the wake of the war.

Such a degree of connectedness at disparate levels of Irish society could not persist without being fed - whether by reminiscences, by fresh news, by the education system, by unconscious absorption of sound and image. In terms of memory, the unresolved national issues inevitably produced repetition, both orally and in written form, of those tales of the past. But the 1890 s had their own new visions too, and the frequency and extraordinary mixture of newspaper articles relating occurrences in France was remarkable. Some came as targeted messages, aimed at bolstering political campaigns within the divided Irish political groups after Parnell; some showed that kind of party political background intertwined with religion and religious concerns; some depicted a brave new world outside; some focused on the arts, and others recorded things like minor crime, with or without didactic purpose or any apparent ulterior motive.

7 Anne V. O'Connor in Anne V. O'Connor and Susan M. Parkes (eds), Gladly Learn \& Gladly Teach: Alexandra College \& School, , 866-1966 (Dublin: Blackwater Press, 1984), 19. In the 1870s, attendances averaged over 300 at Saturday lectures in TCD (on History, Astronomy, Greek Literature, Ethnology, Comparative study of languages, Ancient civilisations, Italian, Elementary Physics) at which money was collected for various charities. In $187 \mathrm{I}$ it was given to the 'Mansion House Fund for Relief of Distressed French peasantry'. Grace Neville has identified coverage of the Franco-Prussian war in the Cork Examiner as the main story' in the period. See Grace Neville, 'The People's War: Cork, Ireland and the Franco-Prussian War 1870-71' in Yann Bévant, Anne Goarzin and Grace Neville (eds), France, Ireland and Rebellion (Rennes: TIR, 20II), 49. 


\section{What they said in the papers}

One of the rather typically amazing mixtures of newspaper material is in an I 899 report from Paris. With no subheadings to divide the topics, a single column in the Freeman's Journal ${ }^{8}$ manages to comment on French politics, to intimate a strongly anti-semitic outlook without as much as including the word 'Jew', and to display some ambivalence with regard to Jesuits and M. Deschanel; ${ }^{9}$ it proceeds to describe a senior Notre Dame cleric as 'that great friend of Ireland', thereby positing Gallic Catholic esteem for the Irish. Archbishop Ireland, mentioned in the next segment, was a very progressive cleric in St Paul, Minnesota and hence, possibly, the reservations about him by a number of 'French Catholics'; the column goes on to highlight as exaggerations, by some of those French Catholics, their prognostications regarding 'atheism, licentiousness of manners, unbridled egotism and criminality'. Surprisingly, a paragraph about a retreat for artists seems to have forgiven Huysmans for his literature, no longer associating him with the infamously anti-Catholic Zola. ${ }^{10} \mathrm{~A}$ forthcoming gathering of Celtic scholars is announced without comment whereas, in detailing a French accusation that the Irish historian Lecky lacks 'the vivacity, the intellectual sparkle and grace of Voltaire, Diderot, or Paul Louis Courier', the report's tone tends to imply that such deficiency is a virtue. If that looks like favouring Anglo-Saxon solidity as against Celtic or Gallic verve and dash, it accurately mirrors the paper's contemporary swing to the Conservative party and away from the Liberals. All those subjects appeared in just one

8 Freeman's Journal, I6 January 1899.

9 M. Deschanel (later briefly President of France) was an anti-Dreyfusard.

Io Huysmans's À rebours (I884) did not meet with Catholic approval and his I891 novel Là-bas had featured a black mass. However, his later novels, En Route (1895), La Cathédrale (1898) and L'Oblat (1903) reflected his conversion to Roman Catholicism. The phrase 'former disciple of Zola in literature' conveys a pardon for Huysmans by the Freeman's Journal, distancing him from one whose writings had been placed on the Vatican's index of prohibited readings in 1894 . The paper's selectivity is as remarkable as Irish attitudes at the time of Fashoda. 
column, on one day. Whether the Freeman's Journal was an opinion-maker or reflective of popular feelings, its I899 attitude to Dreyfus marked a complete shift from its position a year earlier when the paper even had reluctant praise for Émile Zola in his pro-Dreyfus campaign. ${ }^{11}$

The mixtures, the contradictions and odd nuances were widespread. The Anglo Celt newspaper reported on a monster rally at Tara in 1898 , part of the 1798 centenary celebrations; quoting Joseph Chamberlain's reference to Léon Gambetta as a genuine patriot, the concluding speaker prayed that Ireland's statesmen, writers and preachers would forever foster a similar spirit of patriotism among the Irish. Citing a Liberal Unionist/antiHome Ruler like Chamberlain is unexpected in the context of such Irish politics; equally odd perhaps was the lauding of the anti-clerical Gambetta, an opponent of Royalist President McMahon for whom the Irish might have had some fondness on account of his name and ancestry.

The exposure of the Irish public at large to matters French was not restricted to core political or religious messages. In 1898 alone, background snippets in newspapers like the Nenagh Guardian, the Kildare Observer, Southern Star, and Westmeath Examiner, showed that their lenses ranged widely. On the surface, the profusion is a trifle bewildering. On Christmas Eve 1898, the Westmeath Examiner published 'The Paradise of Grandmothers', by Charlotte O'Conor Eccles, writing from the Rue du Faubourg St. Honoré. The content could be dismissed as frothy drivel, but the claim that 'nowhere are the elderly treated with such tender affection', strongly suggests a French Utopia. The Kildare Observer 'Varieties' column printed a long succession of twenty-three pretty dreadful 'jokes', but the French are mentioned only at numbers 3 and 22, with Cardinal Fleury portrayed as mean, and a French nobleman put swiftly in his place by Talleyrand. ${ }^{12}$ 'General News' in the Nenagh Guardian ${ }^{13}$ featured twentysix different items, including reports of rabies in Monaghan, a suicide, sev-

II Freeman's Journal, 25 January i898, 8. A reluctant acknowledgment of Zola's rectitude in the Dreyfus affair had also appeared in The Irish Homestead, I9 February I898, $172-3$.

I2 Kildare Observer, 22 September 1898.

I3 Nenagh Guardian, I October I898, 4. 
eral court cases, and an American war tax. In the middle, a brief sentence records: 'In view of the gravity of the present situation in France, the Pope has countermanded the pilgrimage of French workmen due to arrive at Rome.' An additional short paragraph reports that Paris police have 'a new system of dealing with intoxicated persons'; however, the paper concludes: 'It is unlikely that the new stretchers will be much used, as drunkenness is rare in Paris.' Another example of assorted messages is found in the Nenagh Guardian in $1903^{14}$ where, curiously, items with French links feature in the section entitled 'Thurles Notes': one small paragraph headed 'A Very Determined Suicide' reports the death in Paris of 'a rich French landed proprietor who had committed suicide by means of charcoal fumes' and had written his sensations of the experience for as long as he was able. Subsequent sub-headings read 'The massacre of the Cats' (also in Paris), and then 'Red-haired People' over a paragraph where red-haired women, including Helen of Troy and Joan of Arc, are mentioned, all of them deemed to be trouble. The piece is immediately reminiscent of an earlier, infamous comparison between 'transgressions' of fin-de-siècle emancipated women and the 'excesses' of the French Revolution. ${ }^{15}$

Undoubtedly, entertainment can be derived from the pages of old newspapers, but it is also clear that in any given Irish newspaper in this period, as well as in English papers read in Ireland, the depictions of France are not uniform. As they cover quite a broad range of topics, the commentary on France and the French varies widely, or even wildly. Moreover, there were definitely more serious matters than cats and red hair; the developing thrust towards independence or Home Rule brought about ongoing contemporary consideration of how France might be of use, politically and militarily. If a traditional hope had been that French aid might be relied upon to assist the Irish in gaining freedom, some evidence of changing views emerges in the 1890 s. In July 1896 , it was reported in the Shan

I4 Nenagh Guardian, I3 May 1903, 3.

I5 William Barry, 'The Strike of a Sex', Quarterly Review I79 (I894), 293. Hugh Stutfield struck a like note in 'Tommyrotics' in Blackwood's (June 1895), 842. The combination of misogyny and Francophobia was not uncommon. 
Van Vocht that Irish residents in Paris had laid a wreath at the statue of Général Hoche in Paris, 'in grateful remembrance of his services to their country. ${ }^{16}$ In October 1896 , that same journal declares 'the old friendship endures and shall endure. When a blow is struck at France, even our simple unlearned peasants feel sad'. The writer decides why French friendship could be counted upon:

The services of the Irish Brigade to France and of France to the United Irishmen are no warrant that the exigencies of international politics will not one day make France and England join hands - but we have the strongest assurance that antagonism between England and France is deep and enduring because France will never forget the Burning Stake of Rouen, the Prisoner of St. Helena. ${ }^{17}$

A mere six months later, the Shan Van Vocht is less sanguine on that subject. ${ }^{18}$ A very outspoken poem by 'An Craoibhín Aoibhinn' claims that waiting in the past for support from France and Spain only brought shame. More stridently, the poet asserts that every 'amadán' [trans. idiot] should know that the rallying cry will come from Sinn Féin, [trans. our very selves].

\begin{tabular}{|c|c|}
\hline 'Fanamhaint le Congnamh' & 'Waiting for Help' \\
\hline Fanamhaint le Congnamh ón bhFrainc & Waiting for help from France \\
\hline Fanamhaint le Congnamh ón Spáinn & Waiting for help from Spain \\
\hline Na daoine d'fhan & Those who waited \\
\hline Fadó, leis sin & Long ago for that \\
\hline $\begin{array}{l}\text { Fuair siad náire amháin. } \\
{[\ldots]}\end{array}$ & $\begin{array}{l}\text { All they got was shame. } \\
{[\ldots]}\end{array}$ \\
\hline Is mithid fios do bheith & It's high time that \\
\hline Ag gach aon amadán & Every idiot should know \\
\hline Nach bhfuil gáir fair & There's no warning call \\
\hline Is fiú aon aire & Worth heeding \\
\hline Acht ceann Sinn Féin amháin. & But that of Sinn Féin alone. \\
\hline
\end{tabular}

I6 Shan Van Vocht, Vol. I, no. 7 (Belfast), 3 July I896, I 40.

I7 Shan Van Vocht, Vol. I, no. Io (Belfast), 2 October I896, I86. M. Paul-Dubois would later corroborate that assertion, see note 5 above.

I8 Shan Van Vocht, Vol. 2, no. 3 (Belfast), I2 March 1897, 50. An Chraoibhinn Aoibhinn was the pen name of Douglas Hyde, later President of Ireland. 
The following edition saw affirmation of that policy in a ballad line: 'Our Trust - ourselves alone. ${ }^{19}$ But people were still divided and belief in the earlier dependence on help from France had not totally vanished, nor had the wish to recall and stress France's debt to Ireland. This was clear from Denis Moynihan's poem in which emphasis was completely on the long-ago with lines like 'In many a bloody field of France/The sword of Irish valour shone' and 'They swept the fields of Fontenoy. ${ }^{20}$ In contrast to that, a P.J. McCall poem entitled 'Tone and Napoleon: A Christmas Reverie 1797 ' has Tone say: 'And mark instead in Buonaparte's grey eye / A glare that never softened to my cry.' 'Boney', a lengthy article in the same issue, totally demolishes any case for possible French assistance. The writer, 'Isidore', says that previous generations made their mistakes and had their delusions 'like the men of our own day and generation', adding 'the Poles had the same delusions. ${ }^{22}$ Not quite so firmly put, but also challenging assumptions concerning French intervention, was an $\mathrm{I} 898$ play written by Alice Milligan, with the following exchange between Tennant, a United Irishman, and Wolfe Tone. Tennant says, 'But Buonaporte - he is England's enemy', to which Tone responds, 'We can't be sure he is Ireland's friend. He has dreams of empire. Ireland is nothing to him except we can persuade him Ireland can be made a stepping stone to overthrow of England's power. ${ }^{23}$

On the same topic, and in what must have been an extremely influential contribution on account of his position in Irish struggles, the memoirs of Diarmuid O'Donovan Rossa record with some bitterness the response of

I9 Shan Van Vocht, Vol. 2, no. 4 (Belfast), 5 April I897, 69. In a slight re-writing of the song 'Ireland Boys Hurrah' the first verse becomes 'From Dublin's smoke to Connaught's hills / From Cork to Inishowen / We're gathered; Hope our bosom fills / Our Trust - Ourselves Alone.' Shan Van Vocht, Vol. 2, no. I2 (Belfast), 6 December $1897,230$.

22 Shan Van Vocht, Vol. 2, no. 12, 230-2.

23 Shan Van Vocht, Vol. 3, no. 4 (Belfast), 4 April I898, 56-60. 'The Green Cape', a play for three persons, was set in an inn outside Paris in Autumn i897. Between them, Tone and Tennant add a verse to 'The wearing of the Green': 'O may the wind of Freedom / Soon send young Boney o'er / And we'll plant the tree of liberty / Upon our shamrock shore.' 
Lamartine to the Young Ireland leaders of I848. O'Donovan Rossa takes 'very little stock in all the talk that is made by Irishmen about France or Russia, or any other nation doing anything to free Ireland for us. They may do it, if it will be to their own interest to do it. ${ }^{24}$

Between newspaper columns and journal writings, France and the French were paraded before the Irish in a myriad of different modes, with contrasting packages available for diverse audiences and classes. Of considerable import and relevance in formation of public perceptions is the fact that some news had, for one reason or another, drastically limited circulation. ${ }^{25}$ Prejudice and partisanship and propaganda can be discerned in places and, overall, as the considerable variety fleshed out the pictures of France for readers, who could ever say how many images affected any individual, or how personal interaction or pressure altered existing notions?

\section{Intersecting influences: education, religion and politics}

The influence of education on Irish perceptions of France gathered considerable momentum in the second half of the nineteenth century. In I864, official sources noted that the Convents of Mercy in Ardee and Dundalk taught French and music, if only to middle-class children. ${ }^{26}$ In I892, some prejudice against French was evident on the part of the examination authorities: in Intermediate Board examinations, English, Greek and Latin merited I,200 marks, while French got 700 marks, and

24 Rossa's recollections, 1838 to 1898 (New York: 1898 ), 134. The memoirs were first published in instalments in the United Irishman between 1896 and 1898 .

25 A particularly striking instance was when only two newspapers in the entire country, the Connaught Telegraph and the Tuam Herald, reported the monster meeting in Mayo which gave rise to foundation of the Irish National Land League in 1879.

26 I864 Special Report of Commissioners on National Education in Convent National Schools. <www.scoilnet/womeninhistory/content/unit4/exhibpas>. Accessed 22 March 2012. 
'Celtic' trailed behind with 600 marks. ${ }^{27} \mathrm{~A}$ certain geographical difference and bias could also be discerned: in 1907 in the Ballymena area, Irish was taught in a large number of schools, mathematics in somewhat less than thirty, and French only in three schools and 'to a small number of pupils. ${ }^{28}$ Elsewhere, French was de rigueur in the more prestigious convent schools for girls, and the St Louis sisters in Monaghan actually taught through French. ${ }^{29}$ The influential Jesuit, Fr Tom Finlay, taught French in Crescent College, Limerick from $1872-1878{ }^{30}$ Of the innumerable governesses from France, Sweden, Germany and England who advertised in Irish newspapers for posts in Ireland in the 1860 s and 1870 s, all offered an educational programme that included 'Parisian French'. ${ }^{31}$ In 1900 , the Report of the Intermediate Education Board said 'French is a favourite study, pursued con amore throughout Irish Schools.' Comparative figures bore that out with an increase of 56.6 per cent over ten years (see Table I). At the end of the nineteenth century, the growing interest in French has to be attributed to the fact that several religious orders with French origins and traditions were running schools for the more privileged in Ireland. ${ }^{32}$

27 The Intermediate Board of Education for Ireland allowed students to select any number of subjects for examination provided they included two from Latin, Greek, English, Mathematics and Modern Languages. The Board decided the relevant worth of each subject in marks. <http://multitext.ucc.ie/d/Ireland_society_economy_I870-1914>. Accessed 22 March 2012.

28 Dr Beatty, Inspector of Schools on the Ballymena Circuit, gathered that information in February 1907. Feis na nGleann: a Century of Gaelic Culture in the Antrim Glens, ed. Eamonn Phoenix, Padraig O Cleireachain, Eileen McAuley, Nuala Mc Sparran (Belfast: Ulster Historical Foundation, 2005), I13.

29 <http://www.stlouismonaghan.com/School\%20History.htm>. Accessed 9 May 2012.

30 Fr Finlay was famous for his involvement in literary endeavours, including Lyceum and New Ireland Review (later Studies), and in the cooperative movement with Sir Horace Plunkett.

3I Anne V. O'Connor in Gladly Learn \& Gladly Teach: Alexandra College \& School, I866-Ig66, ed. Anne V. O’Connor and Susan M. Parkes (Dublin: Blackwater Press, I984), 4 .

32 Orders coming to Ireland included the Sacred Heart Sisters (1842), the Faithful Companions of Jesus (I844), Sisters of St. Louis (1859), St. Joseph of Cluny (I860), 
Table I: 'French is a favourite study, pursued con amore throughout Irish Schools' (Report of the Intermediate Education Board 1900)*

\begin{tabular}{|c|c|c|c|}
\hline Year & Total nos & Boys & Girls \\
\hline 1 900 & 7,608 & 4,8 10 & I,832 \\
\hline 1910 & I I,900 & 7,294 & 3,709 \\
\hline
\end{tabular}

* Susan M. Parkes, A Guide to Sources for the History of Irish Education I780-1922 (Dublin: Four Courts, 2010), 63.

Scientific education in Ireland was in touch with France too - in I890 the Albert Agricultural College in Dublin pioneered the use in Ireland of a French method for treating fungal infection. It turned out to be the first successful treatment of potato blight, something that struck a particular chord in Ireland. ${ }^{33}$ One might fairly conclude that, with considerable exposure to French language and literature and information at different levels of the educational system, France was continually on the radar of Irish people.

Never off the radar was one Jeanne d'Arc and the many different interpretations of her life and work facilitated exploitation of her name and history in promotion of diverse causes. It is evident that military and political facets of Joan's legacy, as well as her religion and her Frenchness, were widely and differently employed. Joan of Arc was the name invoked in the I 880 os to defend women's active participation in the Ladies' Land League and in public charitable work in those years - that was Joan as pioneering woman, active in the public sphere, militant when the situation demanded it. On 2 October 1896, an article in The Shan Van Vocht, waving a stick at Britain, and with a tone that seemed particularly encouraging to Irish separatists, reminded readers that 'Under Joan of Arc, Freedom was

La Sainte Union des Sacrés Coeurs (1862), Sacred Heart of Mary (I870), and the Marists (1873).

33 The archives of the Albert College report this. $<$ http://www.ucd.ie/archives/html/ university/aaci.htm $>$. Accessed 8 May 2012. 
decreed to France. ${ }^{34}$ In I 898, Maud Gonne was lauded in the press as the Irish 'Joan of Arc'. Yet, there were other aspects of the Joan legacy. In May I 896, advertisements from Dublin booksellers M.H. Gill, in the Freeman's Journal, ${ }^{35}$ listed their five top-selling books: interest in France was evident in the position of Stuart Henry's Paris Days and Evenings at number 3, while Personal Recollections of Joan of Arc by Sieur Louis de Conte (translation by Jean François Alden) was at number 4 . The alleged author de Conte soon turned out to be Mark Twain/Samuel Clemens and the discovery may have been unsettling for some. However, in June I896, James Duffy, booksellers, offered a different 'Life of the Venerable Joan of Arc' (in $4 \mathrm{~d}$ or $6 \mathrm{~d}$ editions). ${ }^{36}$ The emphasis on Joan's sanctity and martyrdom, not to speak of her 'persecution' by English forces, held attractions for a section of an Irish, Catholic readership. It was a good moment to advertise such books since the Freeman's Journal reported that the cause for the beatification of Joan of Arc was being put to the Vatican council that month. ${ }^{37}$ Joan was not actually beatified until 1909 , and was only canonized in 1920 , but while her history troubled several, she had obviously been sanctified in the minds of many in Ireland long before those dates and her popularity continued. In April I897, it was reported that yet another writer was offering a life of Joan of Arc. ${ }^{38}$ Fittingly, the turn of the century launched Joan in the modern world: by 1901, she was on the silver screen in the 'Extraordinary Electric Cinematograph', an innovatory slideshow at the Rotunda which was described as 'the biggest hit in Dublin for years'; she was returned there again on the Cinematograph in Holy Week of $1902 .{ }^{39}$ The interweaving

34 Shan Van Vocht, Vol. 2, no. Io (Belfast) 2 October I896, I86.

35 Freeman's Journal, 20 May and 30 May 1896.

36 Freeman's Journal, 24 June 1896.

37 Freeman's Journal, 25 June 1896, I2.

38 Mary Hartwell Catherwood, The Days of Jeanne d'Arc. Freeman's Journal, 6 April I897.

39 Freeman's Journal, II April I901. Some of the other items featured on the programme were: 'Actual war scenes from China' and 'Obsequies of Victoria'. In 1902, the show was described as 'Edison's Pictures' and it included a Passion play as well as the Joan of Arc feature, football matches and St Patrick's Day celebrations. Freeman's Journal, 24 March 1902. 
of a glamorous new medium with a multi-faceted older story had dual capacities: it could remove the figure of Joan from topical relevance to a realm of fashionable entertainment; equally, it might copperfasten belief in whichever feature of a fifteenth-century life was perceived comforting and/or useful in reinforcing political or religious battle stances. In the Irish situation, matters political and religious could never be totally separate. Hence, Joan of Arc was, for a lengthy period, a particularly apt emblematic figurehead, an ally as potentially powerful as was her country of origin. In both person and country, the political attractions derived much from sharing a mutual enemy; their religious allegiances also formed a common bond against that adversary, and with the additional advantage of presumed approval of a higher power. Moreover, it is noteworthy in the Irish environment of the fin de siecle that the token heroine or role model, although lauded and espoused for very different reasons, could provide some small common ground that fostered the notion of a common sense of Irishness.

\section{France: a Catholic country?}

If it was frequently taken for granted in Ireland that France was a Catholic country, that conviction was yet another one which was open to different understandings and uses. By the early 1900s, any such clear-cut images and allegiances were replaced in the media by more complicated portrayals. In a fairly dispassionate account of social and political life and progress in Ireland, M.J.F. McCarthy wrote off French Catholicism as 'a mere Death's Head and skeleton of a religion. ${ }^{40}$ The dismissal, in connection with his arguments concerning the optimal way forward for an Irish church, was

40 M.J.F. McCarthy, Five Years in Ireland I895-Igoo (London: Simkin, Marshall, Kent \& Co. Ltd; Dublin: Hodges Figgis \& Co. Ltd, 190I), 317. 
brief but it circulated widely, appearing in his book, Five Years in Ireland I895-I900, a work that ran to several editions in I90I alone. ${ }^{41}$

Results of linkage of church and state, and of their separation, were considered by T.B. Cronin in the Irish Independent in $1905 .{ }^{42}$ Cronin sought to explain how legislation could be hostile to the Catholic Church in a Catholic country. In his view, the French people acquiesced in that enmity and persecution by their silence. While Irish clergy stood by their people in hard times, the French clergy, being state officials who shared in the general unpopularity of such officials, would not resist for fear of 'retrenchment or total suspension of salary'. Yet he claims that French clergy are as pious and learned as any others, and religion is as strong in France as ever, adducing as proof the large donations sent from France to the Pope. $\mathrm{He}$ reminds the Irish of the outcry against Irish priests over the Parnell split, and avers that the Irish look to politics to remedy grievances whereas the French do not, at least not by the ballot. Cronin argues that, distrusting the ballot, they leave the country in the hands of 'an active unscrupulous few like the Jews and the Masonic body', or if things get really bad, they resort to revolution. He blames the 'Godless schools' of France for adding to this unhappy shackling of church to state but is optimistic that, as happened before in history, the strong Catholic roots will ultimately prevail. The headings and subheadings on Cronin's article are designed to catch the eye and lodge in memory: 'Picture of France', 'The Religious Crisis', 'Clergy and people, 'Heart of the Country sound', 'The godless schools'.

Two weeks later under a headline 'Church and State', the same paper reported the dismissal of a French bishop ${ }^{43}$ and readers were told several things: that the French council of ministers was discussing the bill on separation of Church and State; that Monsignor Le Nordez, bishop of Dijon, had gone to Rome, although forbidden to do so by the government, and

4I M.J.F. McCarthy, Five Years in Ireland, I-6. 'If I give what appears to be excessive prominence to the sayings and doings of members of the government and of politicians, and to matters connected with the Catholic religion, it is because excessive importance is attached to them in Ireland'.

42 Irish Independent, 24 January $1905,5$.

43 Irish Independent, 8 February 1905. 
had been dismissed from his post by the Pope but without the assent of the French government as was required by the Concordat between France and the Vatican. If the French government now dismissed the bishop, they might be seen to make a concession to the Vatican by copying the Pope's action. Such reportage was challenging for readers since it was not quite simple enough to allow immediate taking of sides; that lack of clarity would easily facilitate a distancing by the Irish from interest in France, and it could start to alter perceptions in all directions. If the phrase 'bewildered and misconceived' was apt in relation to the Irish reaction to $1789,{ }^{44}$ one can see how appropriate it remains at the fin de siècle, and how numerous were the different contributions towards forming Irish views.

The Anglo Celt of is December 1906 gives a strong hint that some Irish perceptions of France had indeed dramatically altered by that date. In a column entitled 'Notes and Comments', the first line flags its political agenda with the brief note: 'Dec 22 1796: French Fleet in Bantry Bay'. Then, embedded between notes on the Dogs Act, farming education, sheep dipping, and photography, there are a few paragraphs of Franco-Irish interest: first, there is mention of the expulsion of the papal nuncio from France, and of bishops and clergy from seminaries; there is suggestion of a Freemason plot; there is a denial of any failure on the part of the clergy, rather it is said that the priests did not seek to lead the faithful for fear of being accused of clerical dictatorship; M. Viviani, the French Labour minister, is quoted as saying that 'we have liberated the people from Faith', and 'we have extinguished in heaven the lights that will never be lit afresh'. The Anglo Celt then takes a new tack: 'In the light of that blasphemous declaration, how do Irish Catholic soldiers in the British army intend to act when the inevitable war between Germany and France shall come on? When the first shot is fired by the Germans, the British army and fleet shall go to the assistance of the infidel nation; should Catholic soldiers do battle on the side of the avowed enemy of God almighty?' The paper has answers: that Irish Catholic soldiers should protest immediately so as

44 See Pierre Joannon, 'The Influence of France on Ireland: Myth or Reality?', in this volume: $2 \mathrm{I}$. 
not to be accused later of mutiny, they should say now that they could not fight. The writer is clear that this is a powerful message, one that would 'make France understand'. The paper intimates that any soldier who died fighting for a Nation whose sole aim was to blot out God's image, would have a very poor chance of salvation! The interweaving of religious prejudice with political agenda was not uncommon but the Anglo Celt's strategy was particularly inventive, even if its anticipated consequences were fanciful. However, their promulgation suggests existence of a receptive segment of public imagination.

\section{Literary influences}

Whether in novel or short story, any literary treatment of France or French characters and situations, would, of course, increase the profile of the country. It would also have the capacity to further complicate Irish perceptions of France, and of how they might be assessed. London was still the centre of the publishing world at the fin de siecle so Irish attitudes would be affected by 'English' fiction as well as by the work of Irish writers. Since a more revealing picture, and a more nuanced understanding of Irish feelings, might conceivably come from Irish authors, it is interesting to consider three such examples: Miss Erin, a novel by M.E. Francis; Esther Waters, a novel, and 'Mildred Lawson', a short story, both by George Moore.

Miss Erin was published in that important centenary year of $1898 .^{45}$ The eponymous heroine decides at a very early age that she would be an Irish Joan of Arc. Depending on the readers' perceptions, that could be either juvenile nonsense or inspiring nationalist rhetoric; because Miss Erin wrote for The Nation, her ambition might be construed as promising ultimate success, or perhaps as treading a path to that well-known combination of 
moral victory and political defeat. In other words, the link to Joan of Arc and France is emphasized, but it is wide open to interpretation.

In contrast, the author of the 1894 best-seller Esther Waters ${ }^{46}$ seems determined to remove Paris from any political arena whatsoever. When William, a footman, elopes with Miss Peggy, a minor heiress, his account says: 'We first went to Boulogne, that's in France; but everyone speaks English there [...] Then we went on to Paris. The race-meetings is very'andy - I will say that for Paris - half an hour's drive and there you are'. Paris is 'all the place for fashion and the shops is good. ${ }^{37}$ Such a Paris would be rather appealing to ordinary citizens. Moreover, the episode is a mere aside and the activities appear morally, politically, religiously, and militarily neutral. Moore depicts France as a place where a servant could consort with both Anglophone and English people, with not a hint of the revolutionary atmosphere so deplored and contemporaneously touted in Britain, nor is there any threat of French invasion. For those of a unionist outlook, this France is quite safe; for those of an Irish nationalist colour, it does not provide inspiration; to the consumer, it is very tempting. ${ }^{48}$

In 'Mildred Lawson, ${ }^{49}$ George Moore provides yet another glimpse of Paris and France. A young aspiring artist, Mildred Lawson, is welcomed to Paris by Englishwoman Mrs Fargus. Initial portraiture of Mrs Fargus is of a bluestocking, an Oxford graduate, a New Woman, and a follower of the French philosophy of Comte; but the much-hyped, stereotypical reading of that exterior is confounded by her actions. Mrs Fargus is seen to be a caring woman, supportive of an ailing husband and helpful to other women; she is not enticed away from a Victorian moral lifestyle by any French philosopher, or by Parisian influences. Since this France of Moore's stories is not seen as a threat to the British Empire or to personal morals, could it be that it is all rather like home? Perhaps not if Irish readers had bought

46 George Moore, Esther Waters (London: Walter Scott, 1894).

47 Moore, Esther Waters, 209.

48 For depictions of Paris and France which offer similarly various readings, see Mary Pierse 'Paris as "Other": George Moore, Kate Chopin and French literary escape routes', ABEI Journal 8 (June 2006), 79-87. 'Mildred Lawson' is the first story in Celibates (London: Walter Scott, I895). 
Marie Corelli's sensational 1890 novel Wormwood: A Drama of Paris, a book that flaunts the details of degeneration, debauchery and addiction to absinthe; it sold in millions. ${ }^{50}$ Furthermore, this is the decade of Sherlock Holmes who, as Watson tells readers, received the Légion d'Honneur; the same Sherlock Holmes could quote from Flaubert. ${ }^{51}$ It is the decade of Dorian Gray with its strong reflections of the much-condemned $A$ Rebours by Huysmans; it is the period of George du Maurier's Trilby, the half-Irish waif who lived in Paris and was hypnotized by Svengali. Clearly, the public had quite an array of stories to read, to absorb, and thence to add to their stock of information concerning France.

As an addendum to those mixed literary examples, it is significant to read the 'Épitre dédicatoire' to George Moore's novel The Lake: it reveals a perception of France as senior partner in any Franco-Irish relationship, France as complex and rich, Ireland as impoverished. Moore says that while an orchestra would be needed to portray the countryside on the banks of the Seine at Valvins, 'une seule flüte' would suffice to reflect 'la tristesse de mon pauvre pays là bas. ${ }^{\text {.2 }}$

so Marie Corelli, Wormwood: A Drama of Paris (London: Richard Bentley, 1890). As Kirsten MacLeod has found, the sales of Corelli's books 'outstripped the combined sales of many of her contemporaries including Rudyard Kiipling, Arthur Conan Doyle and H.G. Wells' Kirsten MacLeod, 'Marie Corelli and Fin-de-Siècle Francophobia: The Absinthe Trail of French Art', ELT 4.I (2000), 66.

5I In the prologue to 'The Adventure of the Golden Pince-Nez', Watson reveals that Holmes received an autographed letter from the French President, and the order of Legion d'Honneur, for the capture of Huret, the Boulevard assassin. Holmes actually slightly misquoted Flaubert (in 'The Redheaded League'), changing 'L'homme n'est rien, l'oeuvre tout' to 'L'homme c'est rien, l'oeuvre c'est tout'.

52 George Moore, 'Épittre Dédicatoire' to the 1905 edition, The Lake, viii. 


\section{Notes and sketches}

Amongst the innumerable ways in which attitudes towards, and understanding of, France could be affected, was through music. Once again, the notes sounding in fin-de-siècle material were diverse: the autumn of 1898 saw newspaper advertisements for the performances of Gounod's Faust and Bizet's Carmen at the Gaiety Theatre in Dublin; it also promised, presumably for different audiences, a performance of The French Maid at the Theatre Royal, following its long run in London. ${ }^{53}$ While those presentations would have been time-limited, there was an ongoing and well-entrenched influence whose tremendous power lay, in the main, in its unconscious sway. Recognizing the effects and the strength of both music and song, John Whelan's I 897 lecture in Dublin claimed: 'victories from the Seine to Danube and the tricolour triumphant over the massed hosts of Europe - the result of one song, the result of an inspired poor lieutenant'. In addition to acknowledging Rouget de Lisle, Whelan also quoted Béranger's lines on the French tricolour, identifying in them the crystallization of national ideals. Taking visual and musical examples from France, Whelan implicitly pleads for similar tools and effects in Ireland. ${ }^{54}$ But what were the Irish hearing and singing at that time? Indubitably, the ballads of Thomas Davis, and the songs of Thomas Moore, both of which cultivated and sustained nationalist spirit. Amongst Moore's songs, 'The harp that once,' 'The minstrel boy, 'O breathe not his name,' 'She is far from the land,' 'Let Erin remember', were known and sung the length and breadth of Ireland, and beyond. They were exported to America and to France, those homes of revolution, and their impact came back again to Ireland. In Australia, at a lecture marking the centenary of Moore's birth in 1779,

53 Freeman's Journal, 29 August 1898 . The French Maid had 480 performances at Terry's Theatre on the Strand in London.

54 Reported in Shan Van Vocht, Vol. 2, no. 13, 8 January I897, IO-13. See also Michèle Milan, 'For the People, the Republic and the Nation: Translating Béranger in Nineteenth-Century Ireland, in this volume. 
it was claimed, 'the Irish melodies are sung tonight in France and Spain by the descendants of the McMahons and the O'Donnells, who oftentimes upheld on the battlefield the banners of their adopted countries, and still uphold their name and glory. ${ }^{55}$ While Moore's melodies were generally disparaged by many Irish revivalists, ${ }^{56}$ they remained the popular choice for generations and their circulation crossed class and political boundaries. Membership of the Moore Centenary Committee illustrates their wide appeal: it included Isaac Butt, Charles Stewart Parnell, Oscar Wilde and his father, and Archbishop John MacHale of Tuam. ${ }^{57}$ In terms of Irish perceptions of France, the significance of such songs was surely that the existence of national stirring music had to be part of the essential cultural package. Music that fostered the Irish sense of dignity would build and project a strong sense of identity and purpose, and thereby foreground the degree of Irish self-respect necessary for engagement with the French as nation to nation. Probably, pragmatic assessment of potential French responses demanded Irish exhibition of such sturdy self-image, in the absence of which France would never be persuaded that Ireland could be a valuable ally in any sphere.

Ideas of France also came silently, both through the French paintings that were hung in Dublin, as well as through paintings by Irish artists working in Paris and Brittany. The strong political purpose of landscape

55 Fr Prendergast's speech was reported in the supplement to South Australian Register I4 June I879, II-I2.

56 Douglas Hyde's view was that Moore 'had rendered the past of Ireland sentimentally interesting without arousing the prejudices of or alarming the upper classes'. See Hyde, 'The Irish Language Movement: Some Reminiscences' rep. in Breandán Ó Conaire ed. Douglas Hyde, Language, Lore, and Lyrics: Essays and Lectures (Dublin: Irish Academic Press, 1986). However, the committee to commemorate Moore's centenary had included Oscar Wilde, his father, Isaac Butt, Charles Stewart Parnell and Archbishop John MacHale. See Maria McHale 'Moore's centenary: music and politics in Dublin 1879' in Proceedings of the Royal Irish Academy Vol. I09C (Dublin, 2009), 390.

Freemans Journal, 25 January 1879; Freemans Journal, 3 February 1879. 
painting in the period has to be recognized..$^{58}$ The French government bought numerous landscape pictures in the last two decades of the nineteenth century, distributing them to galleries around the country with the aims of fostering national identity, and projecting the image of France as a desirable, pastoral, utopia. A similar strategy was followed in Britain with promotion of Constable's picture The Hay Wain ${ }^{59}$ as a symbol of national identity, in denial of the grim realities of industrial work, rural poverty and widespread social unrest. Hence, it can be understood that, contrary to the easy assumptions of many, landscape was definitely not accidental and the French paintings on exhibition in Dublin reflected the taste, the presumptions, the prejudices and the prescriptive purposes of those who put them there.

What was to be seen in Dublin? From the middle of the nineteenth century, the French art on view in Ireland included darkish, stagnant rural scenes, or ancient Norman buildings in Rouen, or dramatic, romantic seascapes; ${ }^{60}$ biblical and historical subjects by French artists were also on display. ${ }^{61}$ However, the 1898 catalogue at the National Gallery of Ireland records that such French-related canvases accounted for only about twenty in a collection of 464 paintings, a very minimal presence that reflects the earlier London-influenced preference and selections; the notable artists were Boucher, Watteau and Poussin, and the more famous subjects were Julia Kavanagh and Lady Morgan. By the end of the nineteenth century, the range was steadily extending, and both the links to France, and the newer depictions of that country, displayed startling changes: a surprising acqui-

58 See for example Malcolm Andrews, Landscape and Western Art (Oxford: OUP, 1999) and Stephen Daniels, Fields of Vision: Landscape Imagery and National Identity in England and the United States (Cambridge: Polity, 1993).

59 National Gallery, London.

60 Examples include Storm at entrance of Mediterranean port by Philip de Loutherbourg $(1740-181 \mathrm{I}), 3 \mathrm{ft} 2 \mathrm{in} \times 5 \mathrm{ft} 3 \mathrm{in}$, purchased 1867 , No. 165 in the catalogue; paintings of Rouen by Edward Hassell ( $\mathrm{fl} \mathrm{I}_{227-1852}$ ), and Calais Fish Market by G. Sims (fl I829-I840).

6I Such as The Entombment by Nicholas Poussin (1594-1665), purchased I882. It would later be entitled Lamentation over the Dead Christ. 
sition at the gallery in I899 was a leaflet entitled 'General Commanding the French Army to the People of Ireland', together with a 'French Song Book', autographed by Wolfe Tone. ${ }^{62}$ That year too, the renowned 'Loan Exhibition' in Dublin marked an introduction to very different French art: the sky was bright over Corot's Avignon from the West, a painting exhibited in Dublin three times between 1899 and 1905 ; there were eight pictures by Corot, two each by Degas and Puvis de Chavannes, and single canvases by Courbet, Manet and Monet. In style, palette and subject, the scope was changing: the bare-breasted Slave Girl ${ }^{63}$ appeared several times between 1902 and I9I3, as did Manet's challenging Eva Gonzales; Monet's impressionistic renditions of Waterloo Bridge and Lavacourt under snow were shown in 1904-1905, and Waterloo Bridge found a permanent home in Dublin in 1905; 1908 was a possible watershed year when Dublin saw male and female nudes, both in paintings by Puvis de Chavannes and sculptures by Maillol. With visual art partially underpinning perceptions of France and the French, resultant opinions could not but mutate and evolve over an eventful decade.

62 Both leaflet and songbook were found on Wolfe Tone and had been kept by Major Sandys who arrested him. The twelve-page songbook includes 'Chant de Guerre aux Vetérans' (to the air of the Marseillaise) on page 9. Catalogue of Pictures and Other Works of Art in the National Gallery and the National Portrait Gallery, Ireland (Printed for Her Majesty's Stationery Office by Alex Thom \& Co. (Limited): Dublin, I898), 412 .

63 The title of the picture and identification of the artist have changed several times. Thomas Bodkin called it 'The Slave' when it was exhibited in 1904 and said it was possibly the work of Eugene Fromentin (1820-1876). When shown by the National Museum in 1905 , it was stated to be possibly 'French School'. 


\section{Conclusion}

Looking at a selection of potential sources from music, literature, oral history, religious orders, journalism, visual art, and other places, is it possible to say that any of them altered Irish perceptions of France? Or, did those elements confirm existing views? It would be rash to offer unqualified assent to either question. The aspects referred to are but drops in an ocean of influences where the personal and the local are powerful factors that bear on perception and could never be quantified. Seeing France cannot be a simple addition of items; neither can assessment of visions be restricted to the content of government records and diplomatic exchanges, or reduced to the status of plain myth. Perhaps a kaleidoscopic theory of vision is the most appropriate one for understanding perceptive processes in relation to France: operating on the principle of multiple reflections, it would involve an ongoing blending and mixing of depiction and angle, with a constant evolution of the mirrored images. At the fin de siecle, 'seeing' France must embrace a multiplicity of truths and viewpoints, and a wealth of speculation. 


\section{Attractive Marginality: Irish Painters in Brittany in the $\mathrm{I} 88 \mathrm{O}$}

Exhibitions of Breton-themed paintings by Irish artists sojourning in Brittany have taken place regularly over the last two decades, whether it is at the Pont-Aven Museum in $1999^{1}$ or at the Crawford Gallery of Art in Cork in $2000 .^{2}$ In September and October of 2010, Limerick's Hunt Museum mounted an exhibition entitled 'The French Connection (\& The Rediscovery of Thomas Hovenden). ${ }^{3}$ It looks back on the influence of pleinairism and the contemporary taste for painting ordinary models, as well as reminding the viewer that towards the end of the nineteenth century, France attracted a considerable number of Irish (and international) artists whose works were very popular at the time. 'The French

I 'Peintres irlandais en Bretagne (1870-1930)', 26 June 1999-27 September 1999, see <http://www.museepontaven.fr/PEINTRES-IRLANDAIS-EN-BRETAGNE. html $>$. Accessed is October 2012.

2 'Irish Artists in Brittany', Crawford Municipal Art Gallery, Cork, 2000. An earlier exhibit was also devoted to Nathaniel Hill in 1993 ('Nathaniel Hill and the Bretons', Milmo-Penny Fine Art, December 2007).

'The French Connection', io September-ıo October 2010, Hunt Museum, Limerick. Online catalogue available at <http://www.adams.ie/clandeboye/documents/ FrenchConnectionCat-small.pdf $>$. Accessed 4 May 2012.

4 In addition to the expected favourite painters such as Sir John Lavery, George Osborne, Charles Lamb or Nathaniel Hill, the 2010 'French Connection' exhibition at Adams sought to display works by lesser known figures such as Thomas Hovenden, a Cork-born artist who became famous in America in the 188 os, as well as Stanhope Forbes (who went on to create the Newlyn school of painting in Cornwall), Mary Kate Benson and Georgina Moutray Kyle. See the online catalogue, 3-4. <http:// www.adams.ie/clandeboye/documents/FrenchConnectionCat-small.pdf > . Accessed II July 2012. 
Connection' surveys the works of painters whose fascination for French subjects (in addition to strictly Breton ones) had much to do with the fact that the country's status as Europe's painterly destination enabled Irish visual artists to address issues of representation and to experiment with new forms. While academic painters in France reproduced scenes from mythology, ancient history or the Bible ad infinitum and exhibited them at the annual Paris Salons, outdoors or plein air painting asserted itself as a step towards reclaiming proximity with life and celebrating nature, landscapes and familiar subjects. Impressionism took this approach one step further, focusing on 'impressions' rather than on detailed realist representation - as of that the rising sun mirroring itself on the sea in Monet's landmark I874 painting, Impression, Soleil Levant.

The Hunt Exhibition takes as its starting point Thomas Hovenden's recently-rediscovered canvas entitled 'The Story of the Hunt' (I880) and the curator draws a parallel between Hovenden's genre painting and Aloysius O'Kelly's similarly Breton-themed portrait of a 'Vendéen from Finistère' (1885). What these works have in common is the fact that they were both made in Pont-Aven, where the artists shared accommodation at the famous Pension Gloanec in the mid-I870s. The two paintings thus offer an opportunity to reevaluate the Irish production in the wider context of French artistic trends in the late nineteenth century. The paintings selected for the exhibition further testify to the stylistic and cultural connection between Irish painters and Brittany, where it is probable that the latter felt at home in the similar, although smaller-scale landscape. They also help in assessing the direct impact of Breton culture on the Irish artists' individual imagination as well as the indirect impact of their production on the public's imagination in their native Ireland. 


\section{From Barbizon to Le Pouldu}

Brittany had held a special place in the public's imagination since the 1830 . Indeed this Western region had come to crystallize the Victorians' thirst for travel and their fascination with Otherness, which expressed itself extensively through a wide number of publications. ${ }^{5}$ It also induced a reverse process through which the Victorian observer of the Breton 'exotic' subject became, in turn, an object of observation for himself. In the I88os, even those of the Irish painters who were born into the Anglo-Irish Protestant élite no longer systematically headed for London for their artistic education as had been the case of William Mulready, Daniel Maclise or Francis Danby in the nineteenth century, and of James Barry earlier. ${ }^{6}$ Brittany at the time offered a vantage point for artists to assess their place, both within the aesthetic canon of realism, and within the Empire as Victorians, as well as Irishmen and women, and eventually as Moderns.

Both French and Irish academic and realist painters had visited Brittany regularly since the 1830 s, and French writers displayed as strong a fascination for the western tip of Europe as did the Victorians. This is shown by, amongst others, the numerous travel books on Brittany ${ }^{7}$ and by the popularity of the translations of Balzac's The Chouans in 1860 and of Renan's i 854 essay entitled The Poetry of Celtic Races in 1892 . French 'atmospheric' landscape painters such as Camille Corot (one of the precursors of Impressionism) or Eugène Boudin (who took part in the first Impressionist exhibition in 1874 ) also ventured into those distant provinces in the 1860 s, although not specifically to Pont-Aven. Later on, as the spread of railways made Brittany more accessible to visitors from the

See Jean-Yves Le Disez, Etrange Bretagne : récits de voyageurs britanniques en Bretagne (I830-1900) (Rennes: PUR, 2002).

6 Brian Fallon, Irish Art 1830-1990 (Belfast: Appletree, 1994), 48-9. For a more extensive study of James Barry, see Fintan Cullen, The Irish Face (London: National Portrait Gallery, 2004).

7 See J.Y. Le Disez, Etrange Bretagne, I2-13. There were early translations into English of Emile Souvestre's writings on Brittany. 
French capital, foreigners came to discover these exotic parts of Europe. Among them were the art students of Carolus Duran, ${ }^{8}$ whose free portrait classes attracted members of the higher society from all over Europe; also there were students of the Académie Julian in Paris. ${ }^{9}$ At the time, Grezsur-Loing near Fontainebleau, and closer to Paris, ${ }^{10}$ was another location where plein air painting thrived; it attracted other European artists, among them the Irish painter John Lavery.

Looking back on the period, it is striking that the first artists' colonies in Pont-Aven were overall foreign. American artists had been staying there as early as the 1850 os, ${ }^{11}$ but it took the enthusiasm of visitors ${ }^{12}$ to build the reputation of Pont-Aven. The closing of the École des Beaux-Arts to foreigners in Paris also prompted a string of American and English naturalists to look in Brittany for more affordable and stimulating places for their art. Thus started the colony where they devoted themselves to the painting of models clad in traditional clothes and of the unspoiled landscape around the village. ${ }^{13}$

Born Charles Auguste Émile Durant (1837-1917), he changed his name to Carolus Duran as a young painter to seem or sound more exotic.

9 The Académie Julian, founded in 1867 by French painter Rodolphe Julian, quickly became an alternative to the French École des Beaux-Arts, especially for women, who were not allowed to apply until I897. The level of French required by the Beaux Arts made it impossible for foreign artists to enter the school, and the Académie Julian thus welcomed many professional as well as amateur foreign artists. Sir John Lavery, The Bridge at Grez (1883). See < http://www.christies.com/LotFinder/ lot_details.aspx ?intObjectID=I369677>. Accessed II July 2012.

II For a detailed chronology of the Pont-Aven school, see < http://www.museepontaven. fr/-Chronologie-.html>. Accessed II July 2012.

I2 They included Henry Bacon in I864, and later the Philadelphia-based painter Robert Wylie who chanced upon the village during a visit to Brittany. Wylie's American friends, some of whom studied in Parisian studios, also visited.

I3 Julian Campbell suggests that aside from cheap living for artists, it is likely that the attraction of Brittany was stimulated by the publication of Henry Blackburn's book Breton Folk - an Artistic tour in Brittany, which 'described in a lively manner the most picturesque towns, and detailed means of transport between them. The artist colonies, particularly Pont-Aven, saw the arrival of a new generation of artists, fresh out of studios in Paris or Antwerp.' (J. Campbell, 'Irish Artists in Brittany', Peintres 
Unlike the Barbizon artists, the painters in Pont-Aven do not evince a unity in style even though most of the works represent Brittany in an elegiac and picturesque mode. A few less-conventional paintings were the exception. ${ }^{14}$ In spite of the enthusiasm for the location, it seems that the Irish artists who joined the existing English-speaking community in PontAven $^{15}$ around 1880 (Augustus Burke and Aloysius O'Kelly were part of it) witnessed the end of an era: a critic writing in L'Union de Quimperlé remarked in 1885 that the 'Breton subject' had reached saturation point, and wondered 'Quel est le pays, le monde assez vaste pour faire une semblable consommation de l' "article breton"?'16 Julian Campbell nonetheless insists that there was a strong popular demand for Breton-themed paintings in Ireland from the r870s onwards, as the annual exhibitions at the Royal Hibernian Academy show. Augustus Burke exhibited sixteen Pont-Aven canvases in $1876-1878$, adding that ' 1884 was the year which saw the greatest concentration of images of Finistère by both Irish and British painters. ${ }^{\text {'17 }}$

Irlandais en Bretagne, ed. Denise Delouche, exhibition catalogue, Musée de PontAven/Crawford Municipal Art Gallery, 26 June-29 September 1999, 13). André Cariou explains that the cost of a model was much more affordable in Pont-Aven than in Paris, another reason for artists to establish themselves there. The place became so popular that there were forty to fifty painters in the summer of 1875 , reaching 100 in I885, thus again confirming the fact that Blackburn's 1880 essay was instrumental in enticing an increasing number of English-speaking artists to Pont-Aven. They included Irish-born Norman Garstin, Henry J. Thaddeus and Nathaniel Hill. (See also André Cariou, Lespeintres de Pont-Aven, Rennes: Editions Ouest France, 1994, rep. 1999, 24.)

I4 Thomas Alexander Harrisson's 1882 painting Chateaux en Espagne which represents a Breton boy daydreaming on a beach (reconstituted outdoors in the courtyard of the Lezaven manor house) received a prize at the 1882 Paris Salon. (See André Cariou, Les peintres de Pont-Aven, 35.)

is The community had grown to a point that local hotels and shops posted information in English. There were 4th July celebrations from 1883 onwards, as well as baseball competitions between Concarneau and Pont-Aven. André Cariou mentions that the population of Pont-Aven increased by 50 per cent between 1866 and I886, reaching 1,566 inhabitants in 1866 (Cariou, 30 ).

16 Edgar Courtois, L'Union de Quimperlé, 22 August 1885 (quoted by Cariou, 36-7).

17 Julian Campbell, 'Irish Artists in Brittany', 27. 
These pictures circulated in Europe and were also shown in Cork, Liverpool or London. Some, such as Nathaniel Hone's port scene at Roscoff, I869, even made their way to the Paris Salon in I868, while Thomas Hovenden's work was shown at the Exposition Universelle in 1878 . But it should be said that critics in academic circles of the time acknowledged the exoticism of the Breton theme rather than its political relevance for the Ireland of the time, or its proximity to any Irish cultural or religious traditions. It was very much considered as a 'continental' topic in its own right - reassuringly foreign, from the colonizing power's point of view, and familiar in its formal treatment that ranged from realist genre painting to impressionist landscapes and portraits. Accordingly, this triggered an affectionate and sympathetic reaction from the public. ${ }^{18}$

The transition between the naturalist and even the Impressionist treatment of the Breton subject was fostered by Paul Gauguin in his search for alternative expressions of shapes and colour. ${ }^{19}$ Faced with economic hardship at the time, Gauguin chose to exile himself to Brittany in 1886 not because he was attracted to the place or the people or even needed a change of subjects but because he felt the need to reach beyond the Impressionists'

I8 Joseph Malachy Kavanagh's 'A Breton Byeway' (I886) illustrates how such works were received by the Irish public: 'it was described as "a very charming and competent work."' The critic of the Dublin University Review Art Supplement commented 'This is an excellent example of Mr Kavanagh's work. The expectant attitude of the kid tells of someone coming along the path and adds a point of human interest to the landscape which renders the picture particularly pleasing.' See $<$ http://www. adams.ie/clandeboye/documents/FrenchConnectionCat-small.pdf>, I8.

I9 The term 'Post-Impressionists' was coined by the English critic Roger Fry, who mounted a show of 'modern French art' in London in I910. He was referring to the individual endeavours of the painters who had participated in some of the I874-1886 Impressionist exhibits such as Seurat, Cézanne, Van Gogh and Gauguin. One should bear in mind that they had all been through the academic schools of France before trying to fix the changing effects of light on canvas and moving on to define their own style. For instance, Paul Gauguin's Paysage Breton (1888) was influenced by Camille Pissaro, but his treatment of lines already announced the radical move to 'cloisonnement' and marked contours in later paintings. 
landscapes around Paris. ${ }^{20}$ His first stay made it possible for him to paint for three months in succession, and to refine his artistic objectives. While his early Breton canvases displayed impressionist features (his works were still much influenced by the Impressionist Pissarro at the time), they already gestured at his interest in masses of colours, in rethinking his conception of space, and in questioning the traditional composition of paintings and contrasting shapes and colours. The display of works by 'Impressionists and synthesists' at the 1889 Paris Exposition Universelle confirmed the rupture with academism and with the declining Impressionist movement. Eventually, Gauguin would even choose to go to Le Pouldu, leaving PontAven as the village where he had hoped to find peace had turned into a battlefield for the ongoing quarrel between 'academic' and 'Impressionist painters. ${ }^{21}$ Together with Émile Bernard whom he had met in I866, Gauguin developed 'synthetism', which would be later theorized by Maurice Denis as follows: 'It is well to remember that a picture before being a battle horse, a nude woman, or some anecdote, is essentially a flat surface covered with colours assembled in a certain order. ${ }^{22}$ To synthesize, he says, does not mean to simplify but to render the object represented more intelligible. ${ }^{23}$

The works of the Irish painter Roderic O'Conor, one of Gauguin's intimate circle, aptly epitomize these fluctuating aesthetic influences at the turn of the century. O'Conor's artistic itinerary literally spans the decades that saw the emergence of naturalist landscape painting in Grez (in I880), and then that of impressionism and of its rejection (while in Pont-Aven).

20 Daniel de Montfreid's famous comment that Gauguin wanted to make the most of this exile by focusing on the 'primitivism' of life there was made afterwards and contemporary critics disagree that Gauguin came looking for primitivism.

2I Denise Delouche, Gauguin en Bretagne (Paris: Apogée, 1996), I3.

22 'Il est bon de rappeler qu'une image avant d'être un cheval de bataille, une fermme nue, ou une quelconque anecdote, est essentiellement une surface plane recouverte de couleurs en un certain ordre assemblées.' See the Musée d'Orsay archive for more details: $<$ http:// www.musee-orsay.fr/fr/ $/>$. Accessed II July 20 I2.

23 Paul Sérusier's painting entitled Le Talisman, L'Aven au Bois d'Amour (I888) was to become the visual manifesto of the French Nabis painters (the 'prophets' in Hebrew) who established the basis for more abstract forms and asserted the liberation from mimesis. The group included Valloton, Maillol, and Vuillard among others. 
It also saw his involvement in the synthetist movement in Le Pouldu in I892, where he stayed with Gauguin and his followers Seguin or Filiger. As Fallon says, 'No one represents more thoroughly the intelligent émigré artist, on the edge of great events and responding to them feverishly. ${ }^{\text {'2 }}$

\section{Defining an Irish cultural space}

It is artistic encounters, such O'Conor's with Brittany in the $188 \mathrm{os}$, which contributed to the definition of the methods and identity of expatriate Irish painters. They came to Brittany in the wake of the British Victorians who sought in Brittany a form of cheap 'orientalism', as Le Disez puts it his study of British travellers in Britain (1830-1900). ${ }^{25}$ The attraction of the region was, he explains, complex and definitely connected with imperialism. There also was a fascination on part of the British Protestants (and possibly Northern Irish painters) for this Catholic 'Other' that the Breton was, and for the fact that this most Catholic province resisted some aspects of French republicanism. The mediation of the public imagination associated with Brittany is of the utmost importance here: for the Victorians in general, Brittany was a welcoming place for artists and a cheap orient where experiencing the 'Otherness' of the Breton at best gave way to a faint questioning of the so-called values of imperialism.

However, unlike British travellers who envisaged Brittany mostly as commodity and as a way to gently test the Victorian imperialist ideology, it may be argued that Irish artists sought a more radical modern locus for creation and self-creation - and this is why I would agree with art historian Fintan Cullen's statement in Visual Politics that 'what needs to be asked is how these artists relate to their home country; with perhaps less dominance

24 Brian Fallon, Irish Art I830-1990, 54.

25 Jean-Yves Le Disez, Etrange Bretagne : récits de voyageurs britanniques en Bretagne I830-Igoo (Rennes: PUR, 2002). 
given to the discourse of modernism. ${ }^{26}$ Seamus Deane stresses that in the case of Ireland, the period following the Union gave rise to growing tension between imperial and national sentiment. Cultural productions were destined to 'make Ireland recognisably part of the United Kingdom, to represent it as a part of the larger system [...]. ${ }^{27}$ Simultaneously, the I 800 s was a time when 'a deeply conservative and nostalgically inclined national sentiment ${ }^{28}$ began to develop in Europe. Speaking about the emergence of national Irish literature, Seamus Deane has also noted that Ireland could only be adequately represented by producing cultural space outside the "canonical "British" forms of representation., ${ }^{29}$ This seems to have been an incentive for travelling to Brittany. Indeed, not unlike John Millington Synge on Aran, ${ }^{30}$ Irish painters conceived of Brittany as a premodern, primitive world that was likely to spur their own creativity. And like Synge, who created an idiolect which assimilated the communal singing on Inishmaan and his personal dramatic idiolect, it may be said that Irish painters created their own visual idiolect by merging the visual codes and constraints of Victorian genre painting ${ }^{31}$ (i.e. realist and sentimental painting) with their own perception of the place. It thus appears that in the later decades of the nineteenth century, they took the strangeness of their native anglicized Ireland literally, by moving to the Continent and creating their own cultural space, away from home.

26 Fintan Cullen, Visual Politics: The Representation of Ireland $1750-1930$ (Cork: Cork UP, 1997), I6I.

27 Seamus Deane, 'The Production of Cultural Space in Irish Writing,' Boundary 2, 21.3 (Autumn 1994), ir8.

28 Deane, 'The Production of Cultural Space in Irish Writing', irg.

29 Deane, 'The Production of Cultural Space in Irish Writing,' I20.

30 Alex Davis, 'Learning to be Brutal: Synge, Decadence and the Modern Movement,' New Hibernia Review, I4.3 (Autumn 20I2), 42.

3I Traditionally, the five categories of representations are as follows: history, portrait, genre (i.e. small-scale, paintings of subjects from everyday life), landscape, and still life. 


\section{From exotic regionalism to the familiar Celtic 'Other'}

Focusing on the way in which the Irish painters' perception of Brittany in that period led to changes in the representation of the Breton subject from merely exotic to somewhat familiar - I shall further suggest that these artists did not so much seek to position themselves within an Irish political/peripheral identity (inspired by the marginality of the Western region they explored) as to interrogate the virtual reality that was the founding principle of naturalism in the 1870 s and 1880 s. Indeed, many of their works obliquely reflect their difficulty in connecting with subjects whose representation was aesthetically coded. In conclusion, I shall show that this realization called for alternative techniques, ones which were to be found through exchange with fellow painters from France and Europe.

Deane writes that from the end of the nineteenth century onwards, 'Ireland's difference [...] was a difference that paraded anachronism as a form of modernity, the form that was opposed to modernization and was, in consequence, culturally richer. ${ }^{32}$ It is no wonder then, that among the Irish artists' favourite Breton topics were the similarly anachronistic, yet 'richer', rural landscapes with market, domestic or beach scenes (often showing fishermen gathering kelp) as well as 'pardon' (local pilgrimage) scenes, and sitters in local costumes. Paintings by Irish artists unambiguously displayed the same defiance of the laws of progress and modernity as took place in literature making Brittany, according to Belfast artist Samuel Taylor 'a delightful old world place. Very primitive [...] and the costumes are most wonderful. ${ }^{33}$ J.M. Synge is an obvious reference in order to understand how the Irish public imagination was reclaimed by spatial displacement (to Brittany, or in his case back to the West of Ireland). As a young man

32 Seamus Deane, 'The Production of Cultural Space in Irish Writing', I26. See also his remark about '... the Celt as dreamy, imaginative, indifferent to the material world' (Deane, I30).

33 J. Campbell quoting Belfast artist Samuel Taylor, in J. Campbell, 'Irish Artists in Brittany', 23. 
studying in Paris in the 1890 s, he was fascinated with works by Anatole Le Braz and Ernest Renan; he even began to learn the Breton language and to write articles about Brittany in Irish newspapers. He wrote about it in his Etude Morbide (I897-I898) ${ }^{34}$ as Davis explains:

In the Etude, Breton culture and the landscape of Brittany grant the persona a vista of an alternative experience of art to that imparted by [...] distasteful metropolitan authors [...] the élan vital of the Breton peasants is in marked contrast to the morbidity and ennui charted in earlier entries in his fictional diary. ${ }^{35}$

Living in voluntary exile on the fringes of Europe was, as Deane puts it, 'the high cultural form of emigration' ${ }^{36}$ for Irish artists. But while the peripheral location of Brittany was also a strategic location for artists (especially writers) to reclaim the clichéd peasant image, they did so more aesthetically than politically. ${ }^{37}$ Indeed the art critic Julian Campbell underlines that the Breton experience:

had a liberating effect upon those Irish artists who worked in Brittany. [...] In the I870s and eighties Brittany helped introduce a new Realism into Irish art, and an interest in rural and peasant subjects. In the I890s and early twentieth century, it brought a new interest in light, and an unprecedented use of colour. [... it] helped

34 Alex Davis, 'Learning to be Brutal: Synge, Decadence and the Modern Movement', 34.

35 Alex Davis, 'Learning to be Brutal: Synge, Decadence and the Modern Movement', 34-5. The sense of primitivism reaches its climax with Synge's trip to the Aran Islands in the summer of 1898 . Davis has an interesting point concerning Synge's position in Aran: quoting Gregory Castle's Modernism and the Celtic Revival (Cambridge: Cambridge UP, 200I), he points to the fact that Synge cannot avoid his own modernity as he is aware of 'his difference from the native subject whose primitive traditionalism/lity ? he desires.' Late Victorian writers were also questioning the idea that the English language was the expression of national identity (see Davis, 4I).

36 Seamus Deane, 'The Production of Cultural Space in Irish Writing', I33.

37 Julian Campbell also notes that very few artists claimed an interest in their Celtic roots. Irish painter Helen Mabel Trevor, who was interested in the 'Celtic spirit' and its legends is the exception rather than the rule (see Peintres Irlandais en Bretagne, ed. Denise Delouche, 4I). As for Nathaniel Hill, he displayed an interest in the poor and beggars in Brittany which echoes the later concerns of Jack B. Yeats. 
some artists to 'discover' aspects of their own country, including the beautiful, but impoverished, regions of the West of Ireland, as J.M. Synge was to do in his writings. ${ }^{38}$

However, Campbell remarks upon the fact that no Irish School emerged from this experience, that the lack of similar artist colonies in Ireland also meant a lack of representation of the extreme poverty of the West, and he points out that their stay in Brittany did not have the same impact on the Irish painters as it did on J.M. Synge. Indeed, as men and women of their times, European artists held stereotypical views of the Celts which had been culturally formed since the eighteenth century. ${ }^{39}$ Joep Leerssen explains that Celticism at the time (in the case of Wales, or Spain, or even Ireland) was 'a form of exotic, romantic regionalism: different from, but not opposed to, mainstream English culture: a dash of colour at the national periphery. ${ }^{40}$ Thus, the artists staying in Brittany relied somewhat, or for the most part, on an invented tradition. What results from this is that, however pleasing the thought might be, the Irish in Brittany did not set about to deliberately depict an imagined community of Celts. It seems that Irish painters in Brittany were in fact looking for a renewed epistemological place where they could produce works that might challenge the fixity of time so present in Victorian narrative painting, rather than for a geographical locale where they could define themselves against England's (or France's) modernity (as was the case of Irish writers). It appears more accurate to envision the Breton subject as a step in this attempt to reclaim a space for painting rather than as an especially Irish space.

38 Julian Campbell, 'Irish Artists in Brittany', 27.

39 Seamus Deane mentions the 'romantic' characterization of Ireland in the late eighteenth century, which 'at first assumes an ecumenical form, whereby the Irish community is envisaged as having a peculiar and exotic origin (Carthaginian, Scythian), that distinguishes it from the English (Saxon, Roman) [...]' ('The Production of Cultural Space in Irish Writing', I2I). This, he says, resulted in books such as Charlotte Brooke's Reliques of Irish poetry (1789), 'to found a national consensus through the melding of the Gaelic-/and English-language-traditions in poetry' (Deane, I2I).

40 See Joep Leersen, 'Celticism', in Celticism, ed. Terence Brown (Amsterdam; Atlanta, GA: Studia Imagologica, 1996), I4. 
Séamus Deane analyses the difference between Joyce and Yeats as two moments in the definition of Irishness and art, rather than as an essential difference in nature. Similarly, I would like to propose that rather than interrogating their own national position (like Yeats), Irish painters in Brittany went against the grain of literary history by first exploring the plurality of knowledge and influences (like Joyce), saving their Yeatsian national moment for later, in the 1920 s and 1930 s as the nation emerged and as works by Paul Henry or Sean Keating asserted the Irishness of their art:

If Joyce claims an epistemological privilege for writing, Yeats claims it for Irish writing. This is not to say that Yeats is more 'nationalist' than Joyce. Rather, it is to point out two different, but connected, moments in the nationalist enterprise in which Ireland as a territory, specific to itself and not parasitically adjunct to England, would be reconstituted (Yeats) or constituted for the first time (Joyce) in writing [...] for Yeats, the Ireland of anachronistically defined modernity is retaining what England had lost in the process of modernisation. [For these painters as] [f] or Joyce, chronicity or anachronicity are irrelevant. The issue for him is spatialisation of that which has been displaced in the dimension of time. History is not ordered in either linear or cyclic fashion. Instead it is thrown into a synchronous space, plural and present. ${ }^{41}$

While it may seem at first that Irish painters set out to represent the exoticism of an almost pre-lapsarian Breton subject (therefore locating it in a chronology), and to epitomize a stalled, nostalgic moment in time, it appears more accurate to envision the Breton subject as a stage in this attempt to define a 'synchronous space, plural and present', which would account for the long lasting popularity of Breton representations.

Joep Leersen argues that while it is possible to read Celticism as something which takes place in a 'centre-periphery polarity', as 'a form of exoticism (actuated by the periphery's troubled relations with the power centre $),{ }^{33}$ or 'as a struggle of historical narratives and self-definitions, ${ }^{34}$

4I Deane, 'The Production of Cultural Space in Irish Writing', 133-4.

42 Joep Leerssen, 'Celticism', 17.

43 Leerssen, 'Celticism', 17.

44 Leerssen, 'Celticism', 17. 
one should not foreground the bipolarity of these analyses such as centreperiphery, hegemony versus power imbalance, etc. In the case of Norman Garstin, the Limerick-born artist, ${ }^{45}$ geographical displacement was actually a way to reclaim a cultural plurality in the form of the interrelatedness between Celtic regions. After Brittany, he travelled to the South of France, then to Italy and Morocco, before settling in Newlyn, Cornwall, where he founded the eponymous school of outdoor painting, with the Dublin-born Englishman Stanhope Forbes. It gathered artists who had been through their similar European Grand Tour. Garstin's spatial displacement epitomizes the ability of Irish painters in that period to move in European circles (like O'Conor with Gauguin) and American ones (like Cork-born Thomas Hovenden who settled in New England). In so doing, Garstin denied the exclusive reading of the Breton subject as an exotic other, and acted upon the space of Celticism rather than providing a strictly political, nationalist reading.

\section{From frozen space to resumed momentum: questioning the limits of form}

Shunning these bipolarities, which are never the subject of their paintings, Irish artists went on to question the ability of realist forms to express time and space. Naturalist paintings from the I880s and I 890 s predominantly focus on picturesque village scenes in which the artist seems to remain at several removes from his models and their quaint lives. Numerous works convey a sense of aloofness, of the odd distance between the artist and the Breton model engrossed in daily chores. Time, or history, seems to have stopped, framing the Breton subject within a picturesque architectural 
moment ${ }^{46}$ which Watson argues, has the comforting ring of remoteness and some of the dignity of antiquity. ${ }^{47}$ The effect is that Breton society is represented as a society that has not submitted to change not unlike the 'paradise stasis in Connemara and on the Aran Islands' ${ }^{48}$ that Synge writes about.

In most paintings, the Irish artists remained distant witnesses, documenting Breton life in an almost anthropological manner, as naturalists. Thomas Hovenden's 'The Story of the Hunt' clearly relies on the popular tradition of Victorian genre painting: here is a canvas about a story that is being told in the intimacy of a domestic space. ${ }^{49}$ Ironically, it is precisely the visual focus on the 'quaintness' of the protagonists which locks both painter and viewer out of the action taking place, and out of the real 'story of the hunt.' Both the process of this pictured storytelling and the location of the painting's subject are significant in that regard: the house walls frame the domestic scene, bathed in the warm light of the evening. But the painting also serves as a metaphor for the limits in the representation of the Bretons, both by Irish artists, and perhaps more generally by all foreign artists, all of whom were left out of the snapshot of the real life they aimed at depicting. Here, the storyteller/painter remains at a distance from the couple, in the shade, pointing at the picturesqueness of the subjects. His romantic vision of happy domestic life and oral communal traditions is undercut by the fact that the viewer and the painter are equally unable to achieve a sufficient degree of familiarity and knowledge of their models, or of the language. This is a very visually and socio-historically realist painting indeed: it purports to give a voice to the models, but leaves its sounds to the imagination, and a narrative definitely suspended.

46 See Mary Kate Benson (1842-1921), A Court, Quimper, Brittany, Oil on canvas, $60 \times 44 \mathrm{~cm}$, The French Connection catalogue, <http://www.adams.ie/clandeboye/ documents/FrenchConnectionCat-small.pdf>, 5 .

47 George Watson, 'Celticism and the Annulment of History', in Brown, Celticism, 208.

48 Brown, Celticism, 2 Io.

49 Thomas Hovenden (1840-1895), The Story of the Hunt, I880, oil on canvas, $63.5 \times 78.75 \mathrm{~cm}$, The French Connection catalogue, 17 . 


\section{New-found images: the real and the symbolic dimension}

In the I880s, painting national and class stereotypes also allowed the Irish artist to position himself as an outside 'eye'/'I', thereby creating himself through vision. In the 1890 s, under the influence of Gauguin in PontAven, formal experimentation with masses of colour, shapes and setting became central to change and led artists to question the limits of realism. It is undeniable that the Breton-themed yet formally radical painting, The Vision After the Sermon (Jacob Wrestling with the Angel), dated I888, takes after the literal representations of prayer scenes in Finistère. ${ }^{50}$ However, Gauguin also brings together the real (landscape, faces and costumes) and what belongs only to the public imagination: 'the landscape and the fight only exist in the imagination of the people praying following the sermon. ${ }^{51}$ Previous hesitant, naturalist representations of these fascinating strangers paved the way for more daring approaches in the 1890 s. O'Conor's works exemplify this in particular, with their radical, bold use of colour and shapes to depict the Breton landscape in Houses of Lezaven ( 1898 ), and in close-up portraits such as Head of a Breton Peasant Girl (c. 1893).

Over the fifty-year period when their presence was recorded, Brittany allowed Irish artists to mature their style from naturalism to expressive realism, impressionism and post-impressionism. Although there is little evidence of this in writings by artists, one is still tempted to say that it took this ex-centric positioning on the margins of France to locate their own

Paul Gauguin, The Vision After the Sermon (Jacob Wrestling with the Angel), I888, oil on canvas, $72.20 \times 91.00 \mathrm{~cm}$. See The National Galleries of Scotland: 'Genesis (32:22-32) relates the story of Jacob, who, after fording the river Jabbok with his family, spent a whole night wrestling with a mysterious angel. In a letter the artist wrote to Van Gogh he said 'For me the landscape and the fight only exist in the imagination of the people praying after the sermon.' < http://www.nationalgalleries.org/collection/ artistsaz/G/3374/artistName/Paul\%20Gauguin/recordId/4940\#.UABEK_VIF8E >. Accessed I3 July 2012.

5I V. Merlhès, Correspondance de Paul Gauguin, 1873-1888 (Paris: Fondation SingerPolignac, 1984), i65. (My translation.) 
Irishness. The physical distance and naturalist stance of the late i 880 os gave way to a stylistic modernity and to a more daring approach acknowledging the proximity of a model who was then no longer a local curiosity mired in a timeless world, but became more of an alter ego. The sitter was at last able to return the artist's gaze, mirroring his/her ability to see himself through the other. ${ }^{52}$ The Breton subject, geographically marginalized (much like the situation of the Irish in Britain), yet attractive because of its removed position in terms of traditions, language and culture, thus served as a magnifying glass for the under-represented Irish face in Ireland. It is true that while they were busy painting these familiar strangers, Irish painters were not confronting the Ireland of their day. But, working from the peripheral position that Brittany was considered to be in at the time, Irish artists were enabled to see themselves differently, and to progressively 'become involved with their own peripheral position within the Union of Great Britain and Ireland. ${ }^{53}$ As Fintan Cullen adds, this was 'not just a story of the periphery making it to the centre', but also 'a story of the periphery being involved with itself. ${ }^{54}$ Brittany was a marginal place even for the French, but it was a centre for the expression of a thriving Irish School abroad the same degree of unity was never quite reached in Ireland at the same period. This chosen marginality and the community of the artists' colonies in the West of France allowed artists to forge their own modernity through contact and exchange with other European and American artists; it made them European moderns even before they reclaimed Ireland as a proper subject for national art in the 1920 s and later, with paintings by the likes of Jack B. Yeats, Paul Henry or Seán Keating. 'Henry's vision of Ireland as

52 Charles Lamb's The Breton Fisher Boy, painted in the mid-I920s as he was staying in Brittany, appears to illustrate this newly-gained aesthetic maturity, as it bridges the gap between the foreign artist, his own Irish milieu and the local Breton subject. Here, the backdrop of the sardine fleet in Concarneau seems to have influenced Lamb's later Irish paintings, such as the one showing Galway hookers by the pier. Lamb was one of the first artists to use the west as a source of subject matter, but it may be argued that his eye was trained in Brittany.

53 Fintan Cullen, Visual Politics, 134.

54 Cullen, Visual Politics 162. 
a rural utopia', Sígle Bhreatnach-Lynch writes, 'coincided with the state's construction of national identity during the thirties, forties and fifties. Because his western imagery was widely reproduced and used commercially to promote tourism at home and abroad, his painting became iconic, fixing what was to become the public's quintessential image. ${ }^{55}$ Brittany in the 188 os thus served as a laboratory where Synge developed his vision of an unspoiled West of Ireland and where Irish visual artists were able to acquire the tools that would enable them to approach landscape and people from a national perspective, and to define the topoi of Irishness in post-independence Ireland.

55 Sighle Bhreathnach-Lynch, Ireland's Art, Ireland's History: Representing Ireland, 1845 to present (Omaha: Creighton University Press, 2007), 80-I. 
PART II

Constructing the Images 



\section{For the People, the Republic and the Nation: Translating Béranger in Nineteenth-Century Ireland}

On a warm July day in Cork in I870, Home Ruler Joseph Ronayne addressed several thousand people who had gathered to demonstrate their sympathy with the French cause during the Franco-Prussian struggle. Ronayne, appointed Chairman for the occasion, thus concluded his speech:

The day is too warm, gentlemen, to address you at length; and I will merely give you, in conclusion, an extract from a little song of Beranger:

List to my secret. That old flag

Under my bed lies hid;

Sacred to glory, war-worn rag,

Thee no informer thence shall drag;

No dastard spy say 'tis forbid.

France, I can vouch,

Will from its couch

The dormant symbol yet unfold,

And wave once more

Her tri-colour

Through Europe uncontrolled.

(Loud and prolonged applause) $^{1}$

While the name of Pierre-Jean de Béranger evokes little recognition in France and in Ireland today, it is striking that a translation of his patriotic lyrics was chosen for that occasion. It is significant because Béranger was indeed hailed as France's national poet for at least half of the nineteenth century. Furthermore, he appears to have been the most translated and the 
most popular French-language poet in Ireland at the time. This suggests a strong Franco-Irish connection which has remained hitherto unnoticed. This essay explores the special relationship between Ireland and Béranger in the nineteenth century, drawing attention to translations of his songs, mostly into English verse, and recording various comments made about him at the time.

Unlike the situation that pertains today, there were very few collections of poems translated from one single French-language author in the nineteenth century. ${ }^{2}$ Yet two such small monographs, both devoted to the songs of Béranger, are to be found in Ireland's library holdings, one written by Michael Joseph Barry (1817-1889), the other by Hubert De Burgh (1845-1877). The sole anthology of French contemporary poetry in nineteenth-century English translation was produced by an Irish translator, a 'Mrs B. Somers. ${ }^{3}$ In her anthology, Somers devotes much space to Béranger's poetry. To date, around twenty Irish translators of Béranger's poems have been identified, and several more remain unidentified; ${ }^{4}$ each has published at least one full poem translated from Béranger. In total, well over two hundred translations have been located, including anonymous and pseudonymous publications. ${ }^{5}$ Yet, despite that obvious popularity in the nineteenth century, Béranger has now been largely forgotten, both in Ireland and in France. He is occasionally mentioned in works on French history, which suggests that he may have become a historical rather than a literary figure. The first part of this essay provides a brief sketch of Béranger. Following this, the impact of his songs in Ireland is examined through the

2 Michèle Milan, 'Found in Translation: Franco-Irish Translation Relationships in Nineteenth-Century Ireland'. PhD thesis (Dublin City University, 2013), 177. <http://doras.dcu.ie/17753/I/PhD_Thesis_Michele_Milan.pdf>. Née O'Reilly; she was a friend of Maria Edgeworth and she dedicated that anthology to her.

4 For the most part, Irishness is defined here by Irish birth. In one or two cases, however, the person was not born, or did not grow up, in the country, but lived and published in Ireland.

5 A comprehensive list of translators and translations is provided in the appendix to Milan, 'Found in Translation'. 
lens of translations, paratexts, and other comments found in the press, with a focus on socio-political themes.

Pierre-Jean de Béranger was a populist, a patriotic and republican songwriter, and he is regarded as a key figure in the creation and propagation of the Napoleonic legend. The popular and political aspects of his poetry had a particular resonance in Ireland, and Béranger provided Irish cultural nationalists with a decisive model of political resistance and cultural-national representation.

\section{Béranger, poet of the people and national lyricist}

In spite of the aristocratic particle added to the family name by his father, Pierre-Jean de Béranger (1780-I857) was from a humble Parisian background. ${ }^{6}$ As a child, he attended 'L'Institut patriotique', a school founded by a disciple of Rousseau. There, children were supposed to recreate a republican society and were taught to play at politics and war. ${ }^{7}$ A child of the French Revolution, the cause of the Revolution and that of the French nation became inextricably linked in his mind from an early age, particularly during the revolutionary wars.

Béranger's popularity as a songwriter began to soar round about I8I3. By that time, he had joined the 'Caveau moderne', a singing club whose members traditionally sang in praise of wine, women and song, a lyrical genre which was largely free from poetical or political ambition. ${ }^{8}$ Although he never fully departed from this epicurean vein, Béranger became increasingly interested, however, in the social and political role of songs. Following the defeat at Waterloo, France's surrender to the Allies, and the establishment

Pierre-Jean de Béranger, Memoirs of Béranger, trans. Anon. (London: Hurst \& Blackett, I858), I4.

7 Memoirs of Béranger, $26-7$.

8 Jean Touchard, La Gloire de Béranger, Vols I and 2 (Paris: Armand Colin, 1968), II5. 
of the Restoration, Béranger began writing songs which reflected the nostalgic Napoleonic spirit that prevailed among many at the time. A staunch opponent of the Bourbon monarchy, during which he yearned for a return to a republican government, Béranger directed his satirical pen towards the court and the clergy. Touchard observes that political songs represented an effective and powerful force during the Restoration and that the epicurean song societies of Paris had now been largely replaced by the 'goguettes', singing clubs which, despite the government's ban on politics in singing assemblies, were more popular and political in tone and character.' The government became acutely aware of the impact of Béranger's songs among the population, and following the publication of his political and anticlerical songs, he was twice imprisoned for seditious libel during the Restoration, in $\mathrm{I} 82 \mathrm{I}$ and $\mathrm{I} 828$. This only increased his popularity.

Most of his friends and admirers, who included various eminent literary figures, agreed that Béranger had elevated the song to a more poetical genre, often comparing him to Horace and Anacreon. He was admired for his patriotic vein, his obliging nature and his independence of mind. Many thought that his name would remain forever immortal in the rolls of fame. Following his death in I857, numerous publications appeared, including various tributes and imitations. However, this in turn played against the 'national poet', initiating a flow of reactions in the name of religion, morality, art, beauty and politics. ${ }^{10}$ Oblivion would soon follow.

Not only is Béranger regarded as a key figure in the creation and propagation of the Napoleonic legend, he is also widely considered to have been instrumental in the Revolution of I830. Moreover, he had a lasting influence on French working-class and activist songwriters. ${ }^{11}$ He expressed the feelings of the popular masses, and, at least for half a century, many held him as the national lyricist and the poet of the people.

IO Touchard, 373-422.

II Ralph P. Locke, 'Béranger, Pierre-Jean de', New Grove Dictionary of Music and Musicians, ed. Stanley Sadie (London: Macmillan, 200I), 300-I. 


\section{Béranger in nineteenth-century Ireland: translators and themes}

The figure of Béranger seems to have attracted the attention of a diverse public. The translators who contributed to the dissemination of his songs in Ireland, and beyond, came from various political and religious backgrounds, including Catholics, Protestants, nationalists and unionists. While many of them would be unknown today, the cluster of Béranger's Irish translators includes some better-known figures such as Mary Anne Kelly (O’Doherty), aka 'Eva of the Nation', Samuel Ferguson, poet and translator from Irish, as well as the 'Fraserians' from Cork, namely Francis Mahony ('Father Prout') and William Maginn. The diversity of their backgrounds is reflected in the different periodicals which disseminated translations from Béranger, ranging from the Dublin University Magazine and Kottaboos to the Nation, the Cork Examiner, James Duffy's Catholic publications, as well as the Fenian organ the Irish People. Yet, there are strong points of convergence, notably a predilection for socio-political themes, and those subjects provide the focus for this essay. Furthermore, notwithstanding the eclectic nature of this group, there is overall a prominent cluster closely related to Irish nationalism, particularly to the Young Ireland movement and the Nation. Perhaps more significantly, the cultural nationalist vein runs deep and wide: most of Béranger's translators share an enthusiasm for Irish history and culture.

The dominant motifs that have emerged in translation from Béranger, and in commentaries on the French songwriter, are those which relate to patriotism, i.e. love of country, nationalism, the republic, 'liberty' and the 'people.' On the one hand, these are broad concepts, and with much overlap between them. On the other hand, they can be correlated with actual events and circumstances when placed in context. Béranger's patriotic cultivation of imperial glories, his references to England and his fear of foreign invasion are crucial too, and they are closely associated with these ideas. The following analysis provides a broad illustration of these various motifs. 
Béranger in nineteenth-century Ireland: the nation, the republic and the people

The patriotic vein is crucial to the reception of Béranger in nineteenthcentury Ireland. One of Béranger's translators was John Thomas Rowland (1825?-1875), contributor to the Nation and translator from the Irish language. ${ }^{12}$ His translations were part of his 'Lecture on Béranger', delivered in the Drogheda Mechanics' Institute in I 858 . When Rowland introduces his translation of a song that he entitled 'The Good Frenchman', he claims: 'It is so full of national love, honour, pride, and independence, that it gives a lesson to the people of all nations, and deserves to be studied in every line, and in every word. ${ }^{13}$ For Rowland, Béranger's songs provide a lesson on patriotism and national self-confidence which, through translation, he wishes to pass on to his own Irish audience. Significantly, fifty years after Rowland's lecture, another paper on Béranger - this time in the Irish language - was read by Father Cathaoir Ó Braonáin as part of the Gaelic revivalist project. The talk was delivered at the Rotunda 'under the auspices of the Dublin Coisde Ceanntair of the Gaelic League', a report of which was published in Freeman's Journal. Similar to Rowland's discourse, the lecture suggested that there was a lesson to be learnt from Béranger: 'The poet who would interpret the feelings and aspirations of the Irish people would learn much from the poetry of Beranger. ${ }^{34}$

I2 He translated 'The Prophecy of Mac Auliffe' for O'Kearney's Prophecies of SS Columbkille (1856).

I3 John Thomas Rowland, Lecture on Béranger, the French Lyric Poet, delivered in the Drogheda Mechanics' Institute, on Monday, February 8th, 1858. (Drogheda: M'Dougall, I 858$), 2$ I.

I4 'Lecture in Irish on "Beranger", by Rev. Cathaoir O Breandain', Freeman's Journal, 17 January 1908. Two of Ó Braonáin’s translations from Béranger appeared in the Freeman's Journal the day before. Ó Braonáin later published more translations as part of his serialized essay on Béranger in Irisleabhar na Gaedhilge, March-June 1908. See also Philip O'Leary, The Prose Literature of the Gaelic Revival, I88I-1921: Ideology and Innovation (Pennsylvania: Pennsylvania State University Press, 1994), 
Fear of foreign invasion and love of country, notes Rowland, are closely related in Béranger's satirical verses on the Allies and the Russians. ${ }^{15}$ For instance, 'Le Chant du Cosaque', one of the most translated of his songs, creates an image of Europe being 'trampled' by the Cossacks and of France as a country subjected to foreign rule. Additionally, there are several songs in which 'Anglo-mania' is the target of Béranger's piques, notably 'Les Boxeurs ou l'Anglomane', translated by 'G.C.' in the Dublin University Magazine, and by Eva of the Nation. In 'Le violon brisé', translated by Francis Mahony as 'The French fiddler's lamentation', Béranger tells the story of a fiddler who refused to play for the Allies, who in turn broke his fiddle. In this song, declares Mahony, 'honest patriotism swells the note and exalts the melody', thereby intimately connecting the poem's inner music with patriotic sentiment. ${ }^{16}$

The Napoleonic myth of a golden age, of past national and military glory, is similarly linked to Béranger's hostility towards the Bourbons and the Allies. One of the most typical and popular songs in patriotic praise of imperial glories is 'Les Souvenirs du Peuple', which was found in several translations in Ireland. Béranger's 'Le cinq mai' (I 82I) was one of several poems composed across Europe upon Napoleon's death and it was translated by Mrs B. Somers as 'St Helena - 5th May, I82r $1{ }^{\text {' }}{ }^{17}$ Illustrative of the spread of the Napoleonic cult, the journal the Celt hailed this song as 'a mighty and mournful hymn, chanted over the tomb of the great warrior. ${ }^{18}$ In 'The Garret' ('Le grenier'), a song popular with translators in Ireland, Napoleon's victory at Marengo is evoked with pride and nostalgia:

79; I am particularly indebted to Ailbhe Ní Ghearbhuigh (NUIG) for pointing me to this Gaelic revivalist interest in Béranger's works.

I5 Rowland, Lecture on Béranger, 21-2.

I6 Francis Sylvester Mahony, The Reliques of Father Prout (London: H.G. Bohn, i860), 275. The translation extract quoted by Ronayne was from Mahony, whose popular translations were originally published in a series of articles in Fraser's Magazine (I834). Ronayne and Mahony were brothers-in-law.

I7 Other such renditions include Manzoni's 'Il cinque maggio' and Lamartine's 'Bonaparte', the latter translated by James Clarence Mangan as 'Napoleon'. The Celt, Io (1857), I50. 
When we learnt by the shouts of the deafening crowd

That Napoleon the fight of Marengo had won!

Loud thunder'd the cannon! Our song was renew'd,

And we praised the lov'd chief and his exploits so bold,

And we said that our France could never be subdued -

One is well in a garret at twenty years old. ${ }^{19}$

It is worth noting that, whereas Béranger only sings of 'faits éclatants' ${ }^{20}$ [brilliant actions/exploits], the anonymous translator further cultivates the Napoleonic myth by adding this explicit notion of 'lov'd chief'.

In 'The Gallic slaves', translated by John O'Hagan, aka 'Slievegullion', the following line illustrates very well the typical nationalist vein in translation from Béranger: 'Wake, nations, wake, and burst your chains!'21 Significantly, this was published in the Nation in 1844 , during Repeal agitation in Ireland. Young Irelander Judge O’Hagan (1822-1890), also translator of The Song of Roland ( 1883 ), is better-known for his nationalist poem 'Ourselves alone'. It can be suggested that this translation by O'Hagan is more strongly or more explicitly nationalist than was the original verse line of 'Peuple, toujours dormiras-tu?' [People, will you always sleep?]. ${ }^{22}$ Béranger's 'Le Pigeon Messager' ('The Carrier Pigeon), translated by De Burgh, Mahony and Maginn, is a philhellenist song that celebrates Greek independence, and thereby is introduced in song a transnational idea of nationalism. Béranger's song 'La Sainte Alliance des Peuples', which also drew the attention of several translators in Ireland, was a plea for a Europe of peoples in opposition to a Europe ruled by monarchs.

Songs such as 'Ma République' ('My Republic') and 'Le vieux drapeau' ('The Old Flag') were both popular with Irish translators, and the lyrics

'The Garret. Air - "While History's Muse. Irish Melody"', Duffy's Irish Catholic Magazine, July i848, I66. The suggested possible accompanying melody is 'While History's Muse - Irish Melody', the title of one of Thomas Moore's patriotic Irish Melodies. The original version can be found in Pierre-Jean de Béranger, Chansons de P.-J. de Béranger: anciennes et posthumes (Paris: Perrotin, 1866), 337-8.

2I The Nation, 5 October I844, 827.

From 'Les esclaves gaulois', Béranger, Chansons, 325-6. 
express a wish for a republican form of government. In the opinion of journalist John Frazer Corkran, Béranger advanced 'the cause of Republicanism in France..23 Themes of the 'republic', the 'nation' and 'liberty' are intrinsically woven together as, for example, in Eva's translation: 'Republics quite my fancy take, [...] Our simple motto - Liberty! ${ }^{24}$ Closely associated with these motifs, and especially with Béranger's anti-monarchical stance, is the recurrence of the words 'tyrants' or 'tyranny'; Rowland uses the terms several times throughout his lecture. In 'The Garret', Young Irelander Michael Joseph Barry introduces the expression 'banded tyrants' where Béranger had only referred to 'Les rois' (the kings). ${ }^{25}$ The translator certainly conveys Béranger's general standpoint, but the choice of words is significant in its representational aspect, denoting outright partisanship. Barry's choice may have been influenced by his own nationalist ideology since the 'kings' in question included England's rulers. Although Barry renounced political activism following the failed 1848 uprising, ${ }^{26}$ his translation work is still in parts expressive of a nationalist ideology. Lastly, the contrasted themes of liberty and tyranny are eloquently illustrated in Maginn's translation of 'Le Pigeon Messager':

Soon, missioned from Athens, come braving again

The tyrants and vultures that frown on thy way.

Return from the Free, and let Liberty's tones

Strikes the ears of our kings on their tottering thrones! $!^{27}$

It is worth noting from this passage that Béranger's anti-monarchical spirit does not seem to have deterred or repelled Maginn who was known for his unionist and establishment views.

John Frazer Corkran, 'Pierre Jean Béranger', Dublin University Magazine, Vol. 5I (April I858), 448.

24 'My Republic', The Nation, 21 May I859, 600.

25 In Six songs of Béranger, trans. M.J. Barry (Dublin: Alexander Thom, I87I), 7.

26 James Quinn, 'Barry, Michael Joseph', Dictionary of Irish Biography, Vol. I, ed. James McGuire and James Quinn (Cambridge: Cambridge University Press, 2009), 343-4.

'The carrier-pigeon', Béranger's poems in the version of the best translators, ed. W.S. Walsh. (Philadelphia: J.B. Lippincott, I888), 58-60. 
Interestingly, Oscar Wilde, who is generally portrayed as an aesthete, emerges as championing the socio-political function of the ballad when he deals with the subject of Béranger and his work. In a review of translations from Béranger, Wilde expresses his regrets that British democracy 'does not use poetry as a means for the expression of political opinion'. Further, he states that 'most modern poetry is so artificial in its form, so individual in its essence, and so literary in its style, that the people, as a body, are little moved by it, and, when they have grievances against the capitalist or the aristocrat, they prefer strikes to sonnets, and rioting to rondels. ${ }^{28}$ It is both interesting and surprising that Béranger's political verve appears to have struck a chord even with some of the most aestheticist writers of the century. ${ }^{29}$

The opening words of the Celt's anonymous article on Béranger are the words of the songwriter's own maxim: 'Le Peuple, c'est ma Muse' [The People are my Muse]. ${ }^{30}$ The theme of the 'people' is crucial to Irish translators' and journalists' understanding of Béranger's character and poetry. The plebeian and populist nature of Béranger is best represented by 'The Plebeian', translated by Eva from 'Le vilain'. Here is the refrain of the song in her translation:

I am plebeian, yes I trow,

I am plebeian, truly so

Plebeian only, rude and low. ${ }^{31}$

In Duffy's Irish Catholic Magazine, an article on 'The Songs of Béranger' claims that Béranger's songs 'are thoroughly democratic.. ${ }^{32}$ It was Béranger's use of popular airs and of simple, ordinary language, which enhanced the democratic and demotic character, and generated a great deal of enthusiasm in Ireland; it caught the hearts and minds of several translators and

28 Oscar Wilde, 'Béranger in England', Pall Mall Gazette, 2I April I886, 5.

29 Seemingly, Béranger was equally admired by Théophile Gautier, strong supporter of an 'Art for Art's sake' approach, cf. Touchard, La Gloire Vol. I., 528.

30 The Celt, II (1857), I69.

3I The Nation, 22 November 1856, 200.

32 Duffy's Irish Catholic Magazine (June I848), I37. 
commentators. William Dowe (1815-I89I), the most prolific amongst Béranger's Irish translators, and yet a figure overlooked in most biographical dictionaries, argues that Béranger 'had often witnessed the melancholy disposition of men collectively, and conceived the idea of songs whose serious tenor should be suited to the poor, the afflicted - in fact, to the people. ${ }^{33}$ Samuel Ferguson, who did not choose to translate Béranger's most political songs, is however remarkable for adopting a colloquial style and ordinary speech which conveys well the plebeian element:

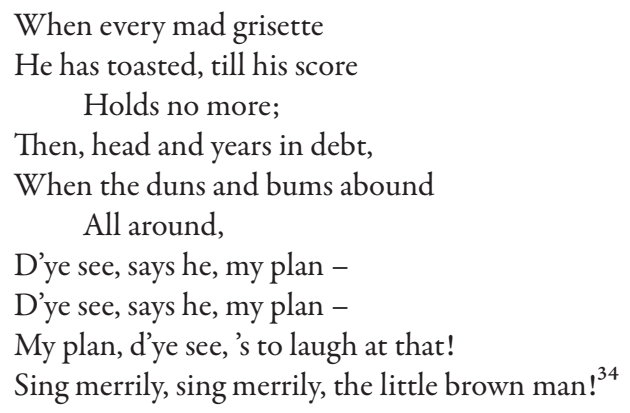

At that time, Thomas Moore and Béranger were frequently compared to each other and the comparison established a connection between the French and Irish cultures, as well as denoting patriotic and demotic strains. Dowe underscores and champions the patriotic element when he argues that both poets 'manifest strong national predilections, and country is the source of the higher inspiration of both. ${ }^{35}$ John Frazer Corkran writes that Moore and Béranger produced 'songs that spoke to the national feeling, and both chose the music of their country as the vehicle of their poetry. ${ }^{36}$ In addition, Béranger was often likened to Scottish poet Robert Burns. Such linkage thereby forged a poetic, even a 'Celtic', connection between the

William Dowe, 'The Songs of Béranger', Dublin University Magazine, Vol. 23 (June I844), 75 I.

34 'The little brown man', Blackwood's Magazine 33 (May i833), 844.

35 William Dowe, 'Béranger and his Songs', Dublin University Magazine, Vol. 23 (February 1844), 205.

36 Corkran, Dublin University Magazine, 448-9. 
three 'national bards'. While the populist nature of Béranger offered a decisive element for any analogy with Burns, it was also occasionally identified as a factor of difference between Moore and Béranger. For Corkran, the Frenchman was 'one of the people', who 'never wished to leave their ranks', whereas 'the Irishman ever sought to rise higher and higher in the social scale. ${ }^{37}$ Drawing an analogy between Burns and Béranger, Dowe claims that they 'both rose in the ranks of the people', and 'both have sung the loves and the business of the poor, and told the story of their virtues and their sorrows, in language of undying truth and beauty. ${ }^{38}$

From the outset of his I 858 lecture, Rowland establishes a Celtic connection between French and Irish cultures, offering to draw the portrait of 'the departed genius of our Celtic brethren of France. ${ }^{39}$ His introduction to the translation 'He is not Dead!' is interesting in several ways. While the song itself offers a good illustration of the Napoleonic legend, as well as a critique of English imperialism, Rowland goes further in presenting the legend of the national hero as a transnational Celtic theme. Indeed he claims that he chose this poem not only because it invokes Béranger's 'great emperor', but, he avers, 'the idea is widely Celtic':

In this country we have the legend of Gerald D'Earla. In Germany they attach it to Frederick Barbarossa. In Scotland it is linked with the history of Thomas of Ereildoune. [...] In all these the superstition tells us of a great departed hero whom his countrymen deem not dead but laid under some magic spell, and again destined to appear as a redoubtable warrior to take part in a final struggle for the salvation of his country. ${ }^{40}$

The links established with Béranger in nineteenth-century Ireland are clearly rich in cultural and transnational constructs. The Napoleonic connection and Napoleonic influences, for instance through Béranger, deserve further attention, notably in relation to broader discussions on

Corkran, 448.

William Dowe, 'The Songs of Béranger', Dublin University Magazine, Vol. 23 (June I844), 752.

Rowland, Lecture on Béranger, 3.

Rowland, 30. 
the Napoleonic myth in Ireland. ${ }^{41}$ However, the focus of this analysis will now be directed towards consideration of Béranger's impact from a more general point of view.

\section{Béranger, Irish cultural nationalism and translation}

In nineteenth-century Ireland, Béranger's songs fired the imagination of Irish poets. The closely connected themes of the 'nation', the 'republic' and the 'people' stand out. In addition, there were other important motifs in translation from Béranger. His cultivation of moral and social themes such as poverty, simplicity, charity, fraternity and the wisdom of old-age, were ones that certainly inspired Ireland's translator-poets. Furthermore, his 'Adieux de Marie Stuart' ('Mary Stuart's Farewell') appears to have provided them with another favourite subject. The epicurean vein is equally important and the bacchanal material and the love songs were popular with several translators. Yet, even in those, Béranger seldom wanders far from his social and political themes. Rather it is the reverse: through Béranger's songs, the public is frequently invited to sing and drink to liberty or to the republic.

It appears that for Irish translators and commentators, Béranger embodied the essence of French culture in various ways, while at the same time providing a universal model. Politician and journalist Justin McCarthy believed that Béranger was 'a true Frenchman', 'essentially national in feeling and spirit', but that he was also 'universal', 'combining in himself many of the greatest attributes of the national genius of many countries'. McCarthy further recognized that some of Béranger's ballads were 'great organs to stir

4I On Napoleonic ballads in Ireland, for example, see Jean-Claude Petiet, and Monique Petiet. 'Napoleon Bonaparte seen through Irish Songs', France-Ireland: Literary Relations, ed. Patrick Rafroidi, Guy Fehlmann and Maitiú Mac Conmara (Paris: Editions Universitaires, 1974), I09-I6; also, Frank Harte and Dónal Lunny, My Name is Napoleon Bonaparte [CD] Hummingbird Records, 2000. 
the soul of the nations. ${ }^{42}$ With the exception of two or three translators, Béranger's anti-clerical lyrics and, above all, his so-called 'indecencies', were generally shunned in translation in Ireland. Echoing many commentators, Corkran contends that there is 'one great stain on the brightness of many of Béranger's earlier lyrics; we allude to their occasional licentiousness, and even grossness - a stain from which his muse is free when she rises to the higher themes of patriotism. ${ }^{33}$ It would appear that moral values were crucial when it came to nineteenth-century translations, and the comments were often indicative of outright scepticism concerning French morality at the time. ${ }^{44}$

Yet apart from his 'mischievous' characteristics, which were at any rate easily forgiven in the case of Béranger, the Irish public could relate to the French songwriter. In particular, there seemed to be an affinity with his witty and satirical side. While several of Béranger's Irish translators shared this characteristic, notably Maginn, Mahony, Barry and De Burgh, the Celt also describes wit as a French characteristic that is fundamental in Béranger. ${ }^{45}$ Overall, Béranger's status as France's 'national bard', his patriotic and republican commitment, and the demotic aspect of his character and works, all engaged the imagination of the Irish public and provided a set of themes which was broad enough to attract translators from a variety of religious and political persuasions. In nineteenth-century Ireland, Béranger's name was commonly invoked as a model for other poets. For example, artist, writer and composer Samuel Lover and Irish nationalist and songwriter Timothy Daniel Sullivan were respectively referred to as 'our Tipperary Béranger' and 'the Béranger of Ireland'. ${ }^{46}$

In addition to translation of his songs, several Irish personalities established direct contact with Béranger. Their personal recollections are particularly illustrative of the themes evoked in this essay. For Lady Morgan,

42 Justin McCarthy, 'Con Amore;' or, Critical Chapters (London: Tinsley Brothers, I868), I48-9.

43 Corkran, 438.

44 Milan, 'Found in Translation', $169-72$.

45 The Celt, io (1857), I50-I.

46 Respectively in The Nation, 9 January I858, 298; The Nation, 16 January 1886, 5. 
the French lyricist was 'a genius and a patriot. ${ }^{47}$ She visited him in the prison of La Force and her words are symptomatic of the affection felt in Ireland for Béranger. She contends that the talents of 'the poet of liberty and of France ${ }^{348}$ are 'directed to the honest purposes of patriotism, and to the furtherance of the cause of liberty. ${ }^{49}$ She often refers to the 'tyranny' to which 'he was subjected. ${ }^{50}$ Engaging in a Francophile discourse that is democratic and republican, she refers to Britain as 'the last stronghold of aristocratic prejudice', in contrast to 'that national sentiment' which, in France, 'values a man for what he is.".

Another key figure in nineteenth-century Franco-Irish relations was John Patrick Leonard (I8I4-I889), who hailed from Spike Island in Co. Cork but lived in France for the greater part of his life. A Paris correspondent of the Nation, and a Franco-Irish mediator par excellence, Leonard translated several religious, historical and political works from French. ${ }^{52}$ He visited Béranger several times and introduced him to 'one of the Irish outlaws of $1848{ }^{\prime 53}$ He sent him translations of Béranger's own songs rendered into English verse, notably 'from the pen of our Irish Poetess "Eva"; they were ones that Béranger particularly admired. ${ }^{54}$ Leonard once wrote to the Nation that Béranger 'was ever deeply interested in the wrongs and

47 Sidney Owenson [Lady Morgan], France in I829-30, Vol. I. (London: Saunders and Otley, 1830$), 258$.

48 Owenson, 491.

49 Owenson, 485.

50 Owenson, 489 .

5I Owenson, 487.

52 See Milan, 'Found in Translation', 239; Janick Julienne, 'John Patrick Leonard (I8I4I889), chargé d'affaires d'un gouvernement irlandais en France', Etudes Irlandaises 25. 2 (2000), 49-67.

53 John Patrick Leonard, 'Beranger: Personal Recollections of the Poet', Part II, The Nation, 28 November I857, 202.

54 John Patrick Leonard, 'Beranger: Personal Recollections of the Poet', Part I, The Nation, is September I857, 42 . 
sufferings of Ireland, and kind to her exiled patriots. ${ }^{35}$ For Leonard, the French lyricist was 'the beacon-light of true patriotism. ${ }^{56}$

An investigation of the relationship between nineteenth-century Ireland and Béranger shows that the cultural nationalist vein running between them is overall quite strong. This is significant in connection with the shaping of cultural nationalism and the importance of ideas of cultural-political nationality in nineteenth-century Ireland. ${ }^{57}$ Various scholars have argued that translation, including poetry translation, came to play a vital role in the Irish cultural renaissance and the emergence of the Irish nation. ${ }^{58}$ From this perspective, translation contributed to the nation-building program of Irish cultural nationalism in the nineteenth century, and its aim was to increase historical and cultural awareness. The appeal of Béranger was broad and international, but his poetry had particular resonance amongst Romantic writers, Republicans, nationalists and radicals across Europe. Béranger had also an impact on various Europeans who attempted to revive a tradition of folk songs and dialectal poetry. ${ }^{59}$ In other words, his songs fed a strain of European cultural nationalism

55 John Patrick Leonard, 'To The Editor of the Nation', The Nation, 26 April I855, 552.

56 John Patrick Leonard, 'Beranger', The Nation, 25 July i857, 760.

57 For discussions of cultural nationalism in nineteenth-century Ireland and Europe, see Joep Leerssen's works: Joep Leerssen, Remembrance and Imagination: Patterns in the Historical and Literary Representation of Ireland in the Nineteenth Century (Cork: Cork University Press, 1996); Joep Leerssen, 'Irish Cultural Nationalism and its European Context', Hearts and Minds: Irish culture and society under the Act of Union, ed. B. Stewart (Gerrards Cross; New York: Colin Smythe, 2002): 170-87; Joep Leerssen, 'The Cultivation of Culture', Nations and Nationalism I2.4 (2006), 559-78. Also John Hutchinson, The Dynamics of Cultural Nationalism: The Gaelic Revival and the Creation of the Irish Nation State (London: Allen and Unwin), 1987.

58 For example, Michael Cronin, Translating Ireland: Translation, Languages, Cultures (Cork: Cork University Press, 1996); Maria Tymoczko, Translation in a Postcolonial Context: Early Irish Literature in English Translation (Manchester: Jerome Publishing, 1999).

59 Touchard, La Gloire de Béranger, 507. See also a summary in Milan, 'Found in Translation', 225-6. The subject still requires further investigation, and could be considered in the light of Leerssen's above-mentioned studies of European cultural nationalism. 
which was seeking out, and drawing on, the demotic roots of culture, and which was both nationalistic and internationalist in perspective. Moreover, several contemporary commentaries and translations point to the power of national ballads such as Béranger's to kindle a flame of patriotic ardour.

The French lyrical poet provided Irish cultural nationalists and republicans with a successful model of political resistance and of cultural-national representation. Commenting on the type of poetry which was published in the Nation, Arthur Griffith, founder of the revolutionary party Sinn Féin, observed that it was 'written deliberately to re-awaken and strengthen the national spirit and inform the national mind'. ${ }^{60}$ Translations from Béranger formed part of that poetical landscape and it may therefore be useful to consider them within this wider framework of national, politico-historical ballads, the type of national poetry which Thomas Davis regarded as 'the very flowering of the soul.'. ${ }^{1}$ The Nation itself once wrote in its own defence: 'We have the same right to awake the memory of past glory, to appeal to the pride of the people, to lament their woes and dissensions, and urge union, and hold out hope, that ever bards had, from Tyrtœus to Beranger.' ${ }^{62}$ Béranger's patriotic and democratic ardour, and his nostalgia for national and military glory through the Napoleonic cult, helped to nourish this fascination for nationality and nationhood in nineteenth-century Ireland. The interest taken in Béranger is therefore also correlated to the idea that song and poetry can represent the national soul in its essence.

The theme of the 'people' is different from that of nationality, and yet it too sometimes carries the notion of a national soul. On the one hand, Béranger was the 'people's poet', the 'universal melodist of emotion. ${ }^{63}$ At the same time, it was often this very 'people', the 'folk', who were said to be the most authentic bearers of a nation's cultural heritage. This close

60 Cited in Matthew Campbell, 'Poetry in English, 1830-1890: from Catholic emancipation to the fall of Parnell', The Cambridge History of Irish Literature, Volume I - To I89o, ed. Margaret Kelleher and Philip O’Leary (Cambridge: Cambridge University Press, 2006), 516.

6I Cited in Campbell, 50 I.

62 The Nation, 24 February I844, 314.

63 The Celt, i4 (1857), 2 II. 
connection established between the nation and the people, in terms of national history, culture and popular sentiment, is best exemplified by the Celt's statement that Béranger passed 'the national history and national character through the burning alembic of his heart, while he reproduced their essence in songs which made the whole people kin, and rendered the minstrel a beloved magician, whose "gentle-spiriting" awakened the national heart to patriotism and glory, to love, good fellowship, and laughter. ${ }^{36}$

Speaking on the influence of songs, the poet Francis Davis also gave an eloquent illustration of the patriotic and democratic themes when he declared the following to an enthusiastic audience:

The history of nations gives us many and glorious illustrations of the power and efficacy of song, as an instrument of regeneration, when wielded by a skilful hand. Look at France, with her Beranger. Look at Scotland, with her Burns. Though, I believe, the introduction of such names - where one so humble as I am is concerned - is little short of profanation; yet, standing out so prominently as they do, one cannot help alluding to them. (Hear, hear.) Burns and Beranger - why, the thoughts of such men grow into guiding spirits and act invisibly amongst us, stealing indirectly upon the heart, weaving a thousand irresistable charms through those musical and talismanic words, human freedom, till the highest altars of tyranny shake or sink, like withered reeds, beneath even the embryo hurricane of popular indignation. $(\text { Hear and cheers. })^{65}$

It is worth noting that this speech was delivered in February I848, with a new revolution about to break out in France and only a few months before the Confederate rising in Ireland.

Undoubtedly, Béranger and his works captured the public imagination at a crucial time in the histories of both France and Ireland, and the linkage represents one of the most remarkable moments of Franco-Irish translation contact. Unlike other nineteenth-century French-language writers, however, his name evokes no immediate recognition today. ${ }^{66}$ In

64 The Celt, io (1857), i48.

65 Cited in 'Banquet to Francis Davis, “The Belfast Man.”, The Nation, I2 February I848, iIo.

66 Unlike Baudelaire, Rimbaud, Flaubert, and Zola, to name but a few; yet, English-language translations of their works were not produced or published in 
this respect, the benefits of translation history cannot be underestimated, because it can increase understanding of past cultural and political relations. That his name should be largely omitted from literary studies today may not surprise us and can, perhaps, be understood in terms suggested by Francis Eccles in 1909: 'For one thing, we are indifferent to the idols and bugbears of that day; and for another, we read instead of singing him. ${ }^{67}$ Béranger was nonetheless a precursor of the French political chanson, setting the pattern for later activist and working-class songwriters. Although this French chansonnier has long been forgotten, his songs 'remain a powerful example of the role that music can play in the propagation of social and political ideology. ${ }^{68}$

The following extract taken from Rowland's lecture might perhaps best sum up the special relationship between Ireland and Béranger. In this passage, Rowland's words about Béranger are sufficiently ambivalent to suggest that he could be speaking for both the Irish and the French people. His emotion is obviously heartfelt, and his message clear:

He was our own - he was altogether of ourselves. We felt what he so happily expressed; we thought as he directed; we enjoyed what he praised; we sung only such songs as were akin to him. We made him a part of ourselves, of our life, of our hearts [...] He, it was, who spoke to us of honour and glory, and the echoes of our soul repeated his songs of liberty; he was the enthusiasm within us, and taught us how to love our country. ${ }^{69}$

nineteenth-century Ireland. For a general overview of trends in translation from French, see Milan, 'Found in Translation'.

67 Francis Yvon Eccles, A Century of French Poets (London: Archibald Constable, 1909), $7 \mathrm{I}$.

68 Locke, 'Béranger, Pierre-Jean de', New Grove Dictionary of Music and Musicians, $30 \mathrm{I}$.

69 Rowland, 4. 



\section{'On the barricades': \\ John Montague's Imaginary Representation of May' 68 in The Pear is Ripe}

It is undeniable that what became known as the 'events of May '68', or even 'May'68', captured public imagination in France and in other countries. Forty years later, it seems more than a little interesting to see how subsequent representations of the events in Paris are refracted through the recollections of an Irish poet. That poet is John Montague, who published the second volume of his memoirs, The Pear is Ripe, in 2007. His first foray into autobiography, Company: A Chosen Life (200I) had dealt with his reminiscences of the fifties and the early sixties, covering his first literary associations in Dublin, Paris and California. The sequel, The Pear is Ripe, refers to 'idyllic Berkeley' in the mid-sixties and then to Montague's return to Paris at the very moment when those May' 68 events occurred. As he says, he was just in time to witness the student rebellion and to find 'a France that seemed on the verge of revolution.'

There is one chapter in The Pear is Ripe which Montague devotes to his experience of the social movement in Paris. Rather than resorting to the conventional modalities of an autobiography that would purport to recount whole stretches of an individual's private life, the poet opts for a more flexible and selective form of a memoir in which to construct a personal representation of May' 68 . In terms of literary genre, this is a remarkable piece of life-writing, one wherein Montague tends to challenge the codes of memoir-writing, thereby successfully arousing the reader's interest in the

I John Montague, The Pear is Ripe (Dublin: Liberties Press, 2007), I63.

2 Montague, The Pear is Ripe, 175. 
particular period of his life that he chooses to explore retrospectively. This sub-genre of autobiography deserves examination, but analysis of it will be accompanied by investigation of the extent to which Montague's personal discourse is informed by the mainstream narrative of 1968 . Those accounts, as revisited by Montague, will also be scrutinized in the light of patterns of interpretations that have been developed concerning the 'events of' 68 ', times that are, more often than not, remembered in the public imagination as a mere hedonistic and libertarian student revolt set against a backdrop of social disorder.

Both the term public imagination and the rather cryptic title The Pear is Ripe, require comment and clarification. By public imagination is meant the popular creative capacity for generating images, symbols and narratives to deal with cultural, social and political realities or personalities; these images and descriptions are those that achieve clear public recognition across space and time, and sometimes lend themselves to myth-making, whether or not they are fully supported by actual facts or deeds. The rather cryptic title, The Pear is Ripe, also demands elucidation: besides being the title of Montague's second volume of memoirs, it is also the title of the chapter that specifically deals with the 1968 social uprising in Paris and its rather telling subtitle is 'or Shall we overcome?'. In its interrogative form, the subtitle echoes the well-known protest song from the Civil Rights movements in the United States in the 1960 s, and thereby suggests contemporary social rebellion. However, the import of the catch-phrase The Pear is Ripe is significantly augmented when put into a literary and historical perspective. It has been 'lifted' from Flaubert's novel, L'Éducation Sentimentale, a work that describes the political involvement of a young romantic hero, Frédéric Moreau, against the backdrop of the 1848 Revolution in France and the nascent Second Republic. At one stage in that novel, one of the insurgents, Deslauriers, writes to Frédéric: 'Mon vieux, la poire est mûre. Selon ta promesse, nous comptons sur toi.' ${ }^{3}$ The pear image refers here to King Louis-Philippe's head as traditionally drawn by the caricaturists of the time. In other words, within the political context, and according to the 
then-prevalent popular imagination, Deslauriers meant that the moment was propitious for the culmination of the revolution. In Montague's words, the symbol of the pear takes on the meaning of a culturally-forged connotation that evokes the spirit of rebellion that smouldered not only in the nineteenth century but also in the late 1960 s. However, the import could be wider in that the reference could equally assume further significance in connection with Montague's private and spiritual life.

The image of the pear is to be found too in an episode from Saint Augustine's Confessions, ${ }^{4}$ in a sort of parable whereby Augustine's selfaccusation about a theft of pears gives rise to a meditation both on the transgression of rules, and also on the subject of sin. While one could never be certain that the latter point was uppermost in Montague's mind when writing his memoirs, the Confessions, as literary archetype, both in form and subject matter, certainly came to bear on his aesthetic approach, albeit in an indirect way through George Moore, whom he credits with an 'autobiographical instinct.' Indeed, Montague claims a Moorian literary legacy and hopes to emulate the technique implemented in Hail and Farewell: 'I have always admired the prose muse, in particular the artful ramblings of George Moore, and hope my efforts may finally weave into a similar tapestry.'

In accordance with that Moorian model, Montague's coverage of the events of May' 68 does not strictly respect factual chronology. However, it follows the associative logic of his mind, with digression and indirection taking precedence over the usual story-line of the French uprising. As the author puts it, 'The technique implemented is revelation by anecdote, as practised by Elias Canetti. ${ }^{7}$ His memoir is neither a day-by-day chronicle of the events, nor a personal diary like the one which Canadian novelist

4 Saint Augustin, Confessions (Paris: Garnier-Flammarion, 1964), Book II, Chapter $4,42$.

5 John Montague, The Figure in the Cave (Syracuse: Syracuse University Press, 1989), 9 I.

6 Montague, 'Preface', The Pear is Ripe, 7.

7 The Pear is Ripe, 7. Elias Canetti (1905-1994) was a Bulgarian German-language modernist, novelist and memoirist. 
Mavis Gallant, for example, wrote at the time for The New York Times, and in which she gave eyewitness accounts of the ' 68 events. ${ }^{8}$ Montague provides an overview of the social movement, and incidentally furnishes glimpses into French politics, but his account nevertheless claims to be a first-hand narrative of 'the drama, the intense street theatre, of Paris,' and one might expect it to be so since the Montagues lived at II rue Daguerre in the I 4 th arrondissement, near Place Denfert-Rochereau, and thus were very near to strategic places, and within walking distance of the Latin Quarter. Yet, far from taking sides on the subjects being debated by participants, John Montague describes himself as a mere 'observer', 'wander[ing] on the margins of the action, ${ }^{10}$ and furthermore, as 'poorly equipped to understand the to and fro that characterised the unexpected events of May' $68 .{ }^{\prime 11}$ It would be wrong to regard his testimony as an objective piece of writing, clinical in its rendition of the events that he happened to witness: 'How could I, as a poet, be immune to this tidal wave of emotions. ${ }^{12}$ Moreover, his account is not always purely from first-hand experience, as it also subsumes elements that he obtained by hearsay and ones gleaned from personal reading. In sum, the Montague memoir does not provide the expected vivid account but rather a carefully assembled and filtered version.

A most striking hallmark feature of Montague's memoirs is that, as befits the genre of memoir, they articulate items of personal interest as well as furnishing social and political data. This is achieved in a seamless but at times most disconcerting way that suggests Montague's rather provocative delight in extending the parameters of the literary genre by imbuing his text with self-centred concerns that are curiously interwoven with social events. Indeed, if much of this piece of 'rag-bag' writing about May '68 offers reflections on the mores of the day, and on the student rebellion and de Gaulle's management of the crisis, a good deal of the chapter is also interspersed with personal domestic information, for instance about

8 Mavis Gallant, Paris Notebooks (London: Bloomsbury, 1988).

9 Montague, The Pear is Ripe, 175.

Io The Pear is Ripe, 175 .

II The Pear is Ripe, 182 .

I2 The Pear is Ripe, 176. 
the sad demise of his cat Kafka: 'In the midst of all this turbulence, our beloved cat, Kafka, sickened and died. ${ }^{13}$ No doubt the bereavement of his feline companion of 'remarkable sensibility' deeply grieved the childless poet but the lumping together of both events within one single sentence cannot fail to puzzle and perplex his readers. Equally unusual is the fact that the narrative of Kafka's final days takes up a whole section in the chapter, a part that is almost as long as the one about the wreckage of the poet's marriage to his first wife, Madeleine. It becomes apparent that Montague's personal life is to the forefront in this chapter that is ostensibly devoted to the ' 68 movement. Moreover, that private life is closely intertwined with social events, as evidenced in the section 'Make Love Not War', in which the reader is told about the way the poet met and started a love-affair with Evelyn, who was one of the rebellious students at the University of Nanterre and who would become his second wife. Boy meets girl and romance meets revolution.

From a more literary viewpoint, the interest of the text lies in its blending of prose and poetry: poems are inserted within the prose, thus creating a mélange of genres with which alternately to address the realities of May '68, and thereby to remind the reader that Montague is first and foremost a poet, and as such, may occasionally be tempted to take an imaginative view of things. One poem, an extract from 'A New Siege' (published in 1970 and dedicated to Bernadette Devlin), serves as an epigraph and it underlines the international dimension of the revolt: 'running voices / streets of Berlin / Paris, Chicago / seismic waves through / a faulty world.' ${ }^{14}$ By inserting this excerpt at the outset of the chapter, Montague clearly places the Parisian uprising within the broader framework of a worldwide movement and shows that, though 'earthed in Ireland', ${ }^{15}$ how alert and responsive he feels to the Zeitgeist of the ' 60 s, and how much he is a poet striving 'to reconcile local allegiances with the absolute necessity of devel-

I4 The Pear is Ripe, I74. The poem was later collected in The Rough Field, 5 th edition

IS
(Newcastle upon Tyne: Bloodaxe Books, 1990), 74.

The Pear is Ripe, 187.

Montague, The Figure in the Cave, I9. 
oping a world consciousness to save us from the abyss. ${ }^{{ }^{16}}$ In the preface to The Rough Field, his 'epic' that was first published in 1972 but composed right through the 1960s, Montague pointedly recalls that: '[e]xperience of agitations in Paris and Berkeley taught me that the violence of disputing factions is more than a local phenomenon. ${ }^{17}$

The second poem that appears in The Pear is Ripe is most appropriately entitled 'Boulevard St Michel', and it is an uncollected piece of poetry which was first published in the immediacy of the 1968 moment (in the Irish Times on I5 June 1968). In these lines, Montague initially depicts the destructive nihilism of anarchist militants through portraying the unfurling of their black flags along the Boulevard St Michel. Then, as if to strike a fair balance in his assessment of the political forces at work at the time, and also to assert his attachment to French Enlightenment principles through a reference to Voltaire, he shows himself, in this poem, to be wary of revolutionary extremism:

\author{
Against everything, \\ For nothing but this destruction: \\ Its cleansing, its terrible joy. \\ The Pantheon glows, \\ Les Invalides glowers, \\ Guevara's beard strangles Voltaire ${ }^{18}$
}

Aesthetically speaking, the technique of blending verse and prose highlights the time gap between Montague's poetical response to the events in the late ' 60 s and then his recollections nearly forty years later. The intermingling contributes to a build-up of tension between the suggestive graphic immediacy of the verse and the perfectly-poised fluid prose of the memoirist who, with the benefit of hindsight, can stand back and write with some irony.

I8 Montague, The Pear is Ripe, I8I. The phrase 'its terrible joy' contrastingly echoes W.B. Yeats's line 'A terrible beauty is born' in 'Easter 1916', The Collected Poems of W.B. Yeats (London; Macmillan, 1961), 203. 
Yet, despite the inward looking propensity of his memoir, not to speak of the time which has elapsed since the events of May'68, or conversely, because of the amount of commentary, allegation, and reports, both oral and written, about those happenings, it could definitely be argued that Montague as a memoirist seems inclined to conform to the usual representation of the Parisian uprising and to fall into step with the dominant discourse, as much in his narrative as in his final assessment of the social movement.

Montague mentions some compelling episodes of the uprising, ones which are, to a degree, inspired by the iconography that has emerged over the intervening decades. These highlights stand as so many vignettes handed down to us today as illustrative of the whole movement. They can be seen as much inspired by black-and-white snapshots and newsreels, hence, for instance, his recollections of street rioting scenes characteristically viewed as sequences 'out of Eisenstein.' ${ }^{19}$ In that respect, it is also significant that the memoirist does not date any of the events that he singles out, as if they had lost their sequential coherence and merely stand for generic milestones that collective memory has marked out as indelible paradigms forming a semantic ensemble. A set of symbolic images verging on clichés, such as 'cobblestones' and 'burning cars', seems to provide a strong sense of déjà$\mathrm{vu}$, or perhaps of a necessarily truncated view of the movement, given the limited amount of space permitted to it in a short chapter. The uprising is dramatized against a backdrop of barricades erected by students who are 'enragés', blockades which are then stormed by the 'infamous' CRS, the riot police forces, whom the poet likens to 'giant insects, ${ }^{20}$ on account of their typical black leather outfits. The symbolic arson attempt on the Stock Exchange, the huge demonstrations, the occupation of the Sorbonne and the Odeon Theatre, and all the poetically sententious graffiti also linger on in Montague's mind, exactly as they do today in the collective memory that is the public imagination. In the same reductive way, the memoirist's cast of May actors only retains the emblematic figures of 'charismatic' Daniel 
Cohn-Bendit or 'Dany the Red', of André Malraux leading the 'middle class in coats and ties' demonstration on the Champs Élysées, ${ }^{21}$ and of de Gaulle as a president who was left in a state of bewilderment. Twice mentioned within a few pages are the reports of de Gaulle's disappearance and secret trip to Baden-Baden, and together with the rumour of a Kremlin conspiracy, these emerge as the components that captured Montague's attention just as they had impacted strongly on the public imagination. The lingering attraction of those episodes must reside in the fact that they were, and still remain, a somewhat mysterious coup de théâtre.

Yet, for all the casual and apparently disorderly remarks and notations, Montague's memoir conveys the image of a man torn between two opposite stances, between supporting the rebels and criticizing their lack of realism. On the one hand, he can hardly suppress his enthusiasm for the student uprising, and he evinces a genuine sensitivity to the romantic revolutionary spirit of' 68 . Experiencing strong empathy for participants, he first feels 'exhilarated', 'fired' by the excitement of the period. Admittedly, revolutions have always provided fertile soil and suggestive references for poets. Montague traces a Blakean energy in the atmosphere of the movement. He appropriately recalls and quotes Wordsworth's celebration of youth during the French Revolution: 'Bliss was it in that dawn to be alive, / But to be young was very heaven!'22 Revolution stands as a moment of idealism closely associated with youth and it remains a subject of poetic inspiration, only later to become a source of nostalgia. However, as the movement loses momentum and impetus, Montague becomes more critical of the turn of events; in the course of time, he lapses into a sort of disenchantment, as Wordsworth did when the French Revolution became distanced from its lofty egalitarian ideals. Montague swerves to a more conservative attitude: he rather reluctantly shares the dismissive scepticism of Beckett, his Montparnasse neighbour, and finds himself at one with Todd Andrews,

22 Montague, The Pear is Ripe, 176; William Wordsworth, 'French Revolution', in Wordsworth. Poetical Works (Oxford: OUP, 1969), 165-6. 
'Our own Irish dragon, that old gunman turned commissar,, ${ }^{23}$ in Andrews's downright disapproval of the young rebels' counterfeit revolution, an interesting attitude given that the latter had himself been a rebel in his day '... not only against England, but against the pro-Treaty government in Ireland: a stormy petrel indeed. ${ }^{24}$

In some respects, it can be said that Montague's ideological ambivalence is played out and symbolized in his private life, torn as he is between two surrogate Mariannes: Madeleine who embodies the bourgeois Gallic character; and Evelyn the passionate student leader, 'storming the barricades, à la Delacroix. ${ }^{25}$ It is Evelyn who, at once embodying youth and rebellion, is perfectly in accordance with the common representation that is universally associated in people's minds with the famous painting, $\mathrm{La}$ Liberté Guidant le Peuple by the French romantic nineteenth-century artist. With clear reference to Montague's passing mention of Delacroix's painting, the dustcover of The Pear is Ripe was illustrated by Irish artist Robert Ballagh's work. His Liberty on the Barricades is a Pop-Art replica of Delacroix's original painting. Both works encapsulate the spirit of rebellion, and each is suffused with romanticism, a combination that certainly marks out common ground between Ireland and France in the public imaginary representations of rebellion at various pulsating stages of their respective national histories. Eugène Delacroix's La Liberté Guidant le Peuple was painted in 1830 , a short time after the Paris uprising of 27-29 July 1830, a revolt that brought about the fall of King Charles X and his replacement by King Louis-Philippe. Robert Ballagh's work was produced in the late-1960s, and the most salient feature of this simplified version of the theme is that the red flag has been substituted for the French tricolour. Arguably, the effect is to make the image appear more international and as clearly representative of any rebellion throughout the world against political authority, even if chromatic symbolism is not definitive in Montague's text. In every respect, both of these pictorial works embody political and

23 Montague, The Pear is Ripe, 184.

24 The Pear is Ripe, 185.

25 The Pear is Ripe, 180. 
social change and their thematic engagement connects very closely with those developed in Montague's memoir.

One of the alluring aspects of Montague's work is that his rambling analysis of the events of May '68 also tries to touch on various traits of the French national character and on the psychology of French citizens, although some of his remarks must be construed as tongue-in-cheek statements. Having previously lived for several periods in France, mainly in Paris, Montague could justifiably pride himself on being familiar with French lifestyles. Being knowledgeable in those turbulent days about the lie of the land in the Latin Quarter, he can jocosely predict, in retrospect, that there would be no tomorrow for a revolution in a country of gourmets' that is running short of fresh food: 'Knowing as I did the French attitude towards life's creature comfort, the student revolution began to seem doomed to me: deprive the modern middle-class Frenchman of good meals and wine - even if he is a leftist - and he would be bound to temper his high ideals. ${ }^{26}$ Although the cutting remark evidently draws on the stereotype of the French as gastronomes, and lampoons Parisian bourgeoisie in the process, his approach to French society and politics is more serious. It tends, to a great degree, to epitomize the commonly-accepted view of France as a deeply compartmentalized society, an opinion fostered by the equally widespread assumption that the uprising exacerbated socially divisive tensions.

However, contemporary militancy also contributed to overcoming social and cultural boundaries and it bolstered links between professional sectors. Montague does refer to these unexpected alliances being formed at least temporarily, but the overriding tenor of his discourse tends to convey the vision of a polarized society that is based on a set of socio-biological and political binary oppositions, and that the events only shed light on 'a crevasse between two ways of thinking, the old and the young, the right and the left. ${ }^{27}$ In other words, Montague seems only too ready to embrace the widespread, all-too-familiar interpretation of the French uprising in terms 
of a generation conflict, or of a family saga tinged with Oedipal overtones. This latter interpretation was certainly that of sociologists writing in the wake of Edgar Morin and, above all, Raymond Aron; it was subsequently solidified in a public imagination that then, in its turn, endorsed the idea that May' 68 was no more than a social mishap or a bout of juvenile fever. ${ }^{28}$

While it is not too difficult to see where Montague's sympathies lie, the memoirist shows himself to be critical of the 'exuberance' and 'the festive spirit' of a number of 'children of privilege,' 'playing at revolution.'29 To some extent, his critical dismissal is not a far cry from Julien Green's more conservative stance and his sweeping statement that 'Mai '68 a été comme une énorme crise de puberté [...] une révolte contre le père et ce qu'il représente $^{30}[$ May' 68 was like a huge puberty crisis [...] a rebellion against the father and what he stands for]. However, non-conformism still has its appeal for Montague: 'To think independently and to challenge authority' is, according to him, what should be 'the purpose of learning and the foundation of any democracy. ${ }^{31}$ Those ideals are undoubtedly those of a former educator, as he was at Berkeley, and then later at the Experimental University of Vincennes in 1970. In particular, defiance of authority would chime effortlessly with the nature of the staunch Irish Republican that Montague still is at heart. Comparisons with former uprisings are inevitable in his mind - and arguably just as much so in the general public imagination - and hence his various references to the 1830 and 1848 revolutions,

Edgar Morin's analysis of May 1968 is in terms of a generation conflict: 'la notion d'adulte-père se présentant comme image achevée de l'homo sapiens, à quoi va s'opposer une image inachevée d'adolescence permanente' [The notion of the father-adult presenting itself as the completed image of Homo Sapiens against which an uncompleted image of permanent adolescence is going to pit itself]. In Edgar Morin, Claude Lefort, and Jean-Marc Coudray, May I968: la brèche, premières réflexions sur les événements (Paris: Fayard, 1968), 77. Raymond Aron's judgement was: 'Nous sommes en présence d'un phénomène biologique autant que social' [We are in the presence of a phenomenon that is as much biological as social]. In Raymond Aron, La Révolution Introuvable (Paris: Fayard, 1968), 53.

29 Montague, The Pear is Ripe, 185.

30 Julien Green, Journal V, Ce qui reste de jour : 1966-1972 (Paris: La Pléiade, 1977), 556.

3I Montague, The Pear is Ripe, I85. 
respectively through Delacroix and Flaubert, but also to the Paris Commune in 1871 , and to the Algerian War from 1954 to 1962 , through a recollection of casualties and damage: 'although there were rumours of more students deaths than officially reported, they were never confirmed. Nor did it (May '68) match the violence of the street fights during the Algerian War, and certainly not the Commune, when thirty thousand people died, and one third of the city was burned. ${ }^{32}$

However, although he judges May ' 68 by the standards of previous insurrections in terms of achievement, degree of violence and death toll, Montague still denies any specific identifying label to the ' 68 movement, but somehow intimates that France was, and maybe still is, a land of revolutions, a country that continually develops a tradition, and even a culture, of social rebellion. This is a viewpoint or interpretation that is not uncommon, and it may strongly contribute to notions prevalent in the Irish public imagination. For example, on the occasion of the fortieth anniversary of May '68, Lara Marlowe, Paris correspondent for The Irish Times, wrote: 'May'68 was the latest in a series of French revolutions stretching over more than two centuries. ${ }^{33}$ Montague further extends the comparisons when, thinking back to Ireland's past, he writes, not without irony: '[o]f course, May '68 is now as mythical as Easter $1916 .{ }^{34}$ The intimation is, in the first place, that had all who claimed participation in the historic events actually been there, then the outcome of those failed revolutions would have been different, and in addition, that they were far too numerous for the poet 'to number them in the song,' to parody W.B. Yeats' poem. ${ }^{35}$ Montague's statement also points to the fact that, in the last analysis, being inscribed as myths within public imagination and thus fuelled by malleable collective memory, the constructed stories of those insurrections are open to

32 The Pear is Ripe, $\mathrm{I} 8 \mathrm{I}$.

33 Lara Marlowe, 'France still in the thrall to the rebel spirit of May'68', The Irish Times (26 April 2008), 4.

34 Montague, The Pear is Ripe, 175.

35 W.B. Yeats, 'Easter 1916', The Collected Poems of W.B. Yeats (London: Macmillan, 1961), 203. 
interpretation, and thence to distortion; or, to put it simply, the mythical significance of uprisings outweighs the actual events.

While May' 68 is regarded by some as marking a kind of rupture with the past, or by others, as at least a crucial period of transition in French life, it lives on, as such, through collective imagination. However, this social movement cannot claim to be an episode as potent and life-changing as were the great revolutions of the past and it is often perceived as a cultural rebellion that led to a more emancipated type of society, rather than as a proletarian upheaval. An opinion poll published by Le Nouvel Observateur news magazine ${ }^{36}$ (and cited in the aforementioned Irish Times article about the celebrations of the fortieth anniversary) testifies to such an interpretation. Montague's rag-bag narrative of May ' 68 is, to a degree, informed by this consensual version of the movement, depicting it as stripped of any deep socio-political implications, but nonetheless meshing with a retrospective and general support of the insurgents. His memoir seems to be couched in a hybrid style of writing, conflating personal recollections and the doxa surrounding the uprising. His testimony is not monolithic but polyphonic in nature, as it develops a nexus of various public beliefs, with inclusion of reported rumours, and quotations from a private letter in which Todd Andrews gives his opinion. The whole text leaves an impression of inconclusive discussions. Admittedly, this befits the genre but the effect thus produced is often one of a higher degree of ambivalence and indecision than in canonical memoirs. Such a result is produced by the inner debates; and it is stylistically conveyed through an insistent use of concessive connectives such as 'yet', 'but' or 'however', and with a number of questions being left unanswered as regards the nuances and aims of the social movement. By integrating enduring clichés and rumours spread by eager and willing public imaginations, Montague's discourse upholds the

36 CSA Opinion-Corporate, 'Que reste-il (sic) de mai 1968?', Sondage n $0800384 \mathrm{~A}$ (Mars 2008) in Marie-France Etchegoin and Sylvain Courage, 'Les Français sont attachés à l'héritage de 1968', Le Nouvel Observateur (27 March 2008), <http:// tempsreel.nouvelobs.com/file/490906.pdf >. Accessed 7 July 2013. <http://tempsreelnouvelobs.com/le-quotidien-de-1968/20080327.OBS6807/les-francais-sontattaches-a-l-heritage-de-1968.html>. Accessed 7 July 2013. 
thesis that the events of' 68 still belong to the realm of mythology, and have not yet entered the sphere of history. His unease at assessing what the elusive ' 68 movement meant induces him to rely on the commonly-accepted 'official' story, yet this propensity may also be ascribed to the fact that the contractual discourse of the memoir genre is necessarily more exposed to, and involved with, the exterior world and what is said about it. Indeed, if the memoirist strives to give his own version of facts, he also feels impelled, however unwittingly, to weave their associated public representations into his narrative tapestry.

Other than the overt political dimension, the dominant image of the student uprising in France foregrounds a subversive libertarian spirit, 'l'esprit de mai 68', one that may have been inchoate in its aims but was often associated in public imagination with unrestricted sexual freedom rather than with a distinctive political agenda. That is a brand of countercultural hedonism to which Montague is not totally insensitive, as is signalled by the title of the second section, 'Make Love Not War'. One may wonder to what extent his libertarian leanings specifically tie in with his experience of the events of May '68 in Paris; it seems probable that they relate more strongly to his early personal development and to his confrontation with the mores of the turbulent '6os, whether it be in the United States, or in France, in the earlier half of the decade. Strong credence could be given also to their putative origins in a symptomatic reluctance to comply with the puritanical norms enforced by Northern Irish Catholicism. In an afterword to his memoir, he writes: 'I have said that the part of me which remained a pious Ulster Catholic, a chaste ex-altar boy, collided, in the 1960 s, with both the French style of extramarital sex, and the free-love movement of that decade. ${ }^{37}$ When inserted into the Irish context and perspective, the word 'libertarian' equally assumes a political dimension that, in Montague's work, cannot be divorced or abstracted from the Irish political landscape and historical paradigm. This is apparent when Montague compares the Paris demonstrations with marches in County Tyrone; it is also in evidence in more extensive explorations in his poetical works, in particular in The 
Rough Field. In other words, Montague's libertarian drive is specifically relevant to his overtly nationalist feelings, and cannot be solely connected with the global revolutionary currents of the late 1960 s, although both become and remain closely intertwined with the rebellious spirit of the times that undoubtedly inspired the poet.

On a first reading, John Montague's chapter on May '68 might emerge as a deceptive, casual, and disorderly description of the événements de mai $68^{\prime}$ in so far as it provides a distanced, though slanted, coverage of the various episodes of the social upheaval, and his random first-hand observations do not convey a vivid sense of the events. But this would be a misleading critical approach, and an inadequate and unfair reading. While Montague's account is, in many respects, informed by the mainstream discourse surrounding the movement, in truth it furnishes a highly original and ironic representation of the events. Provocatively, but not surprisingly, it takes liberties with the aesthetic conventions of memoir writing, in order to proffer an alternative narrative of the events of May'68. In the end, Montague's narrative is markedly different from the mythical story of the movement as encoded within the wider public imagination. 



\section{Ian Paisley: \\ Generating French Perceptions of an Ulster Loyalist Leader}

The firmly fixed impressions of figures striding the world stage are, for the most part, media-generated. Convictions blend with visual images in the minds and memories of a public that may never encounter the characters in real life, and whose understanding of statements and actions is coloured, if not totally determined, by media portraits. In France, attitudes and understanding with regard to the Reverend Ian Paisley were forged by French journalists who covered stories of the Northern Irish conflict over many years. The portrayal of Paisley, one of the main participants in Northern-Irish political life for four decades (from 1968 to 2008), and possibly far too often represented as the voice of Ulster Protestantism, was mainly negative during this period. Focusing solely on the national press in France, on account of its numerous and wide-ranging reports and opinions, this article aims to review the image provided by French journalists of the man who, to the amazement of many, became the first holder of the post of First Minister of Northern Ireland on 8 May 2007, and, even more surprisingly, head of an interdenominational, power-sharing government.

Ian Paisley dominated the news headlines in a particular way between I968 and 1972, at a time when his 'fanaticism' and 'sectarianism' were highlighted in the French media. Then, between 1972 (when London instituted direct rule of Northern Ireland) and 1991 (the beginning of the Peace Process), French journalists concentrated their reports on the war between the IRA and the British army. This latter emphasis meant that consideration of Northern-Irish politics, parties and politicians was more or less pushed into the background, surfacing only from time to time. An example would be in 1974 when the French public heard about Ian Paisley 
during the Loyalist General Strike aimed at undermining the Sunningdale Agreements. Then there was Paisley's much-heralded virulent opposition to the Anglo-Irish Agreement in 1985, or his assertion in 1988 at the European Parliament that Pope John Paul II was the Antichrist. But these were sporadic appearances in the French media and it was only from 2003 onwards, following his success in elections to the local devolved Assembly at Stormont, that this colourful figure returned with a vengeance to the French media landscape, maintaining a high profile until 2008 , the date of his retirement from political life.

There were particular aspects to the coverage of Paisley in the French media and one that emerged clearly from the start was the religious element. From 1968 to 1972, Ian Paisley caused much ink to flow in the French press because of his vituperative comments about Catholicism and the Pope, his attacks on the governments of the Republic of Ireland and of Northern Ireland, and because of his problematic actions. The loyalist leader was described in Le Monde as 'a sort of Calvinist Savonarola turned inside-out,' 'a useful scarecrow', a 'belligerent pastor', or yet again as 'a curious mixture of Savonarola, Poujade and a proto-fascist street fighter.' The Communist paper, L'Humanité, talked of a 'dangerous clown', or of an 'Irishstyle Pierre Poujade.'. The Protestant weekly Réforme, mouthpiece of the

I The original French gives camelots $d u$ roi. This organization, whose name means literally 'street-vendors of the King', was the violent wing of Action française, an antidemocratic group which, from the early years of the twentieth century, campaigned to restore the French monarchy. The camelots indulged in violent street protests and are often thought of as the first fascist movement, since they preceded the Italian fascists and the German Nazis by a generation. The quotations given refer respectively to Sydney Ehler's article in Le Monde, I 8 December 1968, 5, and to two articles by Jacques Amalric in Le Monde, 4 September, 1969, 7, and 24-25 August 1969, 3. Savonarola was an Italian monk who, in his home town of Florence, denounced the depraved morality of the Renaissance and the moral excesses of the clergy and the papacy. He was hanged and burned in 1498 and is considered as one of the precursors of the Reformation.

2 The quotations given refer respectively to articles by Martine Monod in L'Humanité, 21 August 1969, 3, and by Claude Kroes in L'Humanité, I6 August 1971. Pierre Poujade (1920-2003) was a French politician and union leader who founded 'Poujadism', a 
Eglise Réformée de France (the mainstream French Protestant Church), even resorted to satire by calling Paisley 'the Pope of the Free Presbyterian Church'. ${ }^{3} \mathrm{He}$ was also represented in L'Express as 'the most fanatical of the Protestant rabble-rousers, ${ }^{4}$ and in Le Nouvel Observateur as 'the thundering, undisputed leader of the fiercely extremist Ulster Protestants.' In their descriptions, French journalists first of all emphasized Ian Paisley's physical bulk, thus painting him as monstrous on account of his physique. Henri Pierre, Le Monde's London correspondent, described him as 'a hefty boy come straight from his country background, with a nose, teeth, hands and feet much bigger than average for common mortals. ${ }^{6}$

At this early stage, Paisley seemed almost akin to the guru of a dangerous cult. Robert de Suzannet of Le Figaro, a conservative daily, declared in December 1968:

With the Reverend Paisley, hysteria and fanaticism come close to madness [...] More of a rabble-rouser than a churchman, this Presbyterian [sic] pastor accused his church of cowardice toward Catholics, of lacking firmness in the face of the Papist threat. He ended up creating his own sect. ${ }^{7}$

Huguette Debaisieux, the newspaper's special correspondent, confirmed this image in 1971, in a major report: 'The temple of Ravenhill Park, where the Reverend Ian Paisley officiates every Sunday evening, has just been built thanks to the huge support of the members of the sect he has created: a church called Free Presbyterianism.8 Clearly, there was a deal of

movement seeking to defend small farmers and businessmen against the political elite. He was a great orator, but also notorious for his xenophobic and anti-Semitic comments.

3 André Sévérac, in Réforme, 13-19 March 1971, II.

4 Claudine La Haye, in L'Express, 25-31 August 1969, 22-4.

5 Yvon Le Vaillant, in Le Nouvel Observateur, 25-31 August 1969, 4-8.

6 Henri Pierre, Le Monde, 22 February 1969, 5. Cf. Le Nouvel Observateur, 25 August 1969, 4-8 and L'Express, 23-29 December 1968, 27.

$7 \quad$ Le Figaro, i8 December 1968. Contrary to this journalist's claim, Ian Paisley was a Baptist before creating his own church, under the name of 'The Free Presbyterian Church'. 
ignorance about Protestantism on the part of French journalists since, unlike Catholicism, the Protestant tradition allows for the creation of new churches without their being considered dangerous sects. With equal ignorance, L'Humanité on 22 April 1969 presented Ian Paisley as 'the leader of the Protestant Church [sic] of Northern Ireland', the journalist seemed not to realize that there is not a single Protestant Church as such, that the Protestant tradition is organized into several churches according to their differing theological orientations (Calvinist/Presbyterian, Lutheran, Anglican/Episcopalian, Methodist, Baptist, and so on). Sydney Ehler, Le Monde's correspondent in Dublin, wrote in 1968 of the 'fearsome Presbyterian [sic] pastor', and declared that 'the Presbyterian Church [sic] has provided a fiery leader and orator. ${ }^{10}$ However, the Free Presbyterian Church that Paisley founded in I95I is not the Presbyterian Church, the latter having been founded in the sixteenth century. Moreover, Paisley was not a cradle Presbyterian but rather a Baptist and his father was a Baptist pastor. It was the case however that the members of Paisley's new Free Presbyterian Church were indeed mainly Presbyterians who had left their original church. ${ }^{11}$

Numerous French special correspondents attended services or evangelical rallies organized by Dr Paisley and wrote detailed reports of his sermons and actions, thereby demonstrating that this was no ordinary pastor. Paisley's obsessive anti-papist ideology was repeatedly and widely highlighted in the French press. Robert de Suzannet of Le Figaro explained, in somewhat ironic tones, that Paisley and his loyalist supporters rejected any idea of the reunification of the island of Ireland because in their eyes, that would simply mean falling under the yoke of the Vatican for - people are convinced of this in the Orange districts of Belfast - it is the Pope in person who dictates his orders to the government of the Republic. ${ }^{12} \mathrm{De}$ Suzannet's colleague, Huguette Debaisieux, stressed the logical absurdity of

9 L'Humanité, 22 April 1969, 3.

Io Le Monde, in December 1968, 5 and 18 December 1968, 5 .

II See Steve Bruce, Paisley, Religion and Politics in Northern Ireland (Oxford: Oxford University Press, 2009), chapter 2.

12

Le Figaro, 18 December 1968, 4. 
Paisleyite reasoning by explaining why Paisley also rejected the Common Market: 'He goes around declaiming en bloc against the Pope and the Common Market. So, he will tell me after the service, you can't expect anything good from such an organisation since its treaty was signed ... in Rome!'. In La Croix, a Catholic daily, Christian Casteran severely condemned Paisleyite ideology:

These extremists from another age take a very poor view of Britain joining the EEC and think this is a very bad blow for Ulster. 'We will be led by Papists', they say. And that is what they reject, at any price. One has to realise that the mentality of the extremist Northern-Irish Protestant has remained at this sad stage of under-development, it is as if a blockage had happened somewhere, obstructing the future. ${ }^{14}$

In his report of a speech made by Paisley at an evangelical rally, special correspondent Casteran also denounced the narrowness of spirit of a person for whom Catholicism, Communism, ecumenism and pacifism were synonymous. ${ }^{15}$ That same Paisley speech was also reported in Le Nouvel Observateur by Yvon Le Vaillant. ${ }^{16}$ Since France had inherited Catholic values (Catholicism was a religion supported by the State until 1905) and was one of the founder members of the EEC, it is clear that the incessant attacks of Paisley against the 'Papists' and the European Community were likely to displease French readers and hence make for good news stories.

Whether as a result of their religious background or political outlook, or a combination of both, some journalists presented Ian Paisley as a clown. Thus, in a major article, one special correspondent of Le Figaro regaled readers with the account of a performance, a 'real one-man show', where the pastor was at the centre 'of a huge platform that looked more like a theatrical stage than a pulpit. For hours, he would play with his microphone like the most experienced "crooner"'. ${ }^{17}$ In the Protestant weekly Réforme, André

\footnotetext{
I3 Le Figaro, II August 197I.

I4 La Croix, 21 August 1971, 6.

I5 La Croix, i9 August 1969, 4.

16 Le Nouvel Observateur, 25-31 August 1969, 4-8.

17 Huguette Debaisieux, Le Figaro, in August 1971, 9.
} 
Sévérac also described Dr Paisley's 'act' and denounced the hypocrisy of a person who used religion for manifestly political ends:

Right-wing extremism is represented by the Reverend Paisley who, caught between two stools, can digest only one idea at a time. According to himself, he preaches Christ crucified at the Free Presbyterian Church from a pulpit of gargantuan proportions. But really this is a political speech. God is only an instrument, the bible an arsenal or a handbook. He mocks the Prime Minister, brings out wooden policemen painted blue, jostles them, knocks their helmets off, sets off everyone laughing, and is wildly applauded. It's an incredible performance. ${ }^{18}$

The same journalist also labels Paisley a charlatan and describes 'a scene of charlatanism that is hard to stomach': 'Paisley discovers a hole of three hundred thousand pounds in his finances that he needs to fill and finds in the Bible the verse that will allow him to deal with the situation. ${ }^{19}$ Numerous other French journalists also presented Ian Paisley as a charlatan who uses the Bible for material gain: Claude Kroes, the special correspondent of L'Humanité, described the 'silent collection, to which you can contribute only banknotes; since the smallest of these, in UK currency, is a pound - I3 francs - this practice brings in a good return.20 Yvon Le Vaillant of Le Nouvel Observateur reported: 'His first sentence is to thank the people who have given money in the morning collection. [...] Then the collection takes place. The collection plate is so heavy that it almost fell out of my hands. ${ }^{21}$ Huguette Debaisieux, special correspondent of Le Figaro, spoke of 'a diabolically clever man' who was able to set up a complete business by selling records of his Sunday sermons, in which he cheerfully mixed 'the gospel and politics, the anti-papist struggle and the battle on behalf of Her Majesty the Queen, proselytism in favour of his denomination and the holy war against the IRA.'22

I8 Réforme, I3-I9 March 197I, II.

i9 Réforme, I3-I9 March 197I, II.

20 L'Humanité, 16 August 1971, 3.

21 Le Nouvel Observateur, 25-31 August 1969, 4-8.

22 Huguette Debaisieux, Le Figaro, in August i971, 3. 
However, there were others who saw Paisley differently and conveyed their judgments to readers. Henri Pierre, Le Monde's London correspondent, refuted the image of a charlatan and a clown, considering that there was no cheating or dishonesty since Ian Paisley was not playing a role, but that he believed resolutely in his cause:

The drama is that he is not a run-of-the-mill demagogue. Dr Paisley is a sincere man who regards himself as a martyr. He really sees himself as a soldier of Christ, fighting the good fight. [...] Unfortunately, the religious fanaticism of this character who really belongs to a different age is the opposite of what Ulster needs today. ${ }^{23}$

Discernment of sincerity sometimes allowed perception of danger too. L'Express mentioned Paisley's militias, ${ }^{24}$ Le Figaro and L'Humanité referred to his 'calls for civil war. ${ }^{25}$ Martine Monod characterized Paisley as a 'dangerous clown', a fascist at the head of a group of terrorists whose 'power' and 'determination' should not be overlooked. ${ }^{26}$ Sydney Ehler, Le Monde's Dublin correspondent, presented him as 'the head of an intransigent paramilitary and anti-Catholic organisation. ${ }^{27}$ Numerous French journalists, including L'Humanitês Martine Monod, Le Nouvel Observateur's Yvon Le Vaillant, Le Figaro's Jean-Michel Goudstikker and Claudine La Haye of $L^{\prime}$ Express $^{28}$ stated that Ian Paisley was leader of the UVF. ${ }^{29}$ This reportage flew in the face of the fact that at no time was Paisley the leader of that paramilitary organization, even if some have alleged that his sectarian

23 Le Monde, 22 February 1969, 5. Steve Bruce, in Paisley, Religion and Politics in Northern Ireland, 248, has also attested to Paisley's sincerity.

24 Basile Tesselin in L'Express, 23-29 December 1968, 27 and John Ardagh in the same magazine, 13-19 September 1971, 42.

25 Robert de Suzannet and Pierre Bois in Le Figaro, 21 August 1969, 3, and Martine Monod in L'Humanité, 21 August 1969, 3.

26 L'Humanité, 21 August 1969, 3.

27 Le Monde, i8 December 1968, 5.

28 See L'Humanité, 20 August 1969, Le Nouvel Observateur, 25 August 1969, 4-8, Le Figaro, 7 July 1970, 3, and L'Express, 25-31 August 1969, 22-4.

29 The UVF or Ulster Volunteer Force is a loyalist paramilitary organization created in 1966. Implicated in numerous sectarian murders and in terrorist bombings in Dublin and Monaghan in 1974, it has respected the ceasefire since 1994. 
sermons could have inspired and triggered certain murders committed by the UVF. ${ }^{30}$ Moreover, as Steve Bruce points out, Paisley often condemned the terrorist actions of the UVF and the UDA. ${ }^{31}$ Nevertheless, a number of French journalists have considered, justifiably, that Ian Paisley had a share of responsibility in the conflict, insofar as, through sermons dominated by his 'anti-papist' obsession, he stirred up hatred between the two communities, an interpretation later confirmed by the Scarman Report of April $1972 .{ }^{32}$ In addition, he was one of those responsible for the formation of several paramilitary organizations, for example the UPV (Ulster Protestant Volunteers) which despite declaring their respect for the law, were responsible for a series of terrorist outrages in 1969. It was Paisley who launched the 'Third Force' in 1981, and then 'the Ulster Resistance' in $1986,{ }^{33}$ in reaction to the signing of the Anglo-Irish Agreement.

Some French journalists tried to provide a deeper analysis of the underlying causes of Ian Paisley's growing popularity: according to Le Figaro's Robert de Suzannet, 'his outrageous statements, which ought to weary public opinion, keep alive in the minds of many people the smouldering cinders of religious intolerance. ${ }^{34}$ Le Monde's Henri Pierre explained that Paisley 'was playing on the fears, and the prejudices of the Protestant middle and working classes. ${ }^{35}$ His colleague Jacques Amalric even accused Paisley of manipulating the working class for the benefit of the Protestant middle class:

By polarizing a sizeable section of the Protestant lower class around the topic of religion, Dr Paisley helps this 'Protestant trash' to avoid asking itself too many questions about the potential absurdity of tearing itself and its neighbours apart, under

See Pierre Joannon, Histoire de l'Irlande et des Irlandais (Paris: Librairie Perrin, 2009), 684-5.

3I Bruce, Paisley, Religion and Politics in Northern Ireland, 21 I, 218, 220.

32 See Violence and Civil Disturbances in Northern Ireland in 1969 (Scarman Report), Belfast: HMSO, April 1972.

33 See Bruce, Paisley, Religion and Politics in Northern Ireland, 226-8.

34 Le Figaro, 18 December 1968, 4.

35 Le Monde, 21 February 1969, 5. 
the cold eye, and for the benefit of, a Protestant elite which does not lower itself to fisticuffs or shooting. ${ }^{36}$

That is exactly the charge levelled by David Ervine, Billy Hutchinson and other Loyalist leaders who emerged from paramilitary groups, and who have often accused Paisley and his acolytes of hiding behind their great speeches and of leaving the fighting to others who end up in prison. ${ }^{37}$ However, it must be said that Paisley's popularity was explicable in the political context of Northern Ireland, in the interlinked elements of religion and nationalism. As Steve Bruce explains:

It is not difficult to see how the political conflict in Northern Ireland exerts a restraining influence on those general social changes that elsewhere have diminished the importance of religion and encouraged a shift in a liberal direction [...] This in turn explains why Paisley could hope to recruit followers. ${ }^{38}$

Paisley was striving to protect his heritage and his identity; in that battle, ecumenism, liberalism, and the creation of the European Union were perceived by him as threats to the values he espoused. His words fell on fertile ground at home and were often heard with horror abroad.

During the first phase of the conflict in Northern Ireland, French journalists often confined depiction of the Protestant community in Northern Ireland to the apocalyptic biblical speeches of Ian Paisley, to the attacks by Loyalist groups on nationalist areas and to the bigotry of the Orange Order. However, numerous moderate Protestants were horrified by the sectarian speeches and threats uttered by Dr Paisley. As Robin Glendinning (of the moderate, centre-ground Alliance Party) emphasized, 'those believers who refused dogmatism and the excesses of religious

Le Monde, 4 September 1969, 7. The term 'Protestant trash' here translates a double metaphor penned by Jacques Amalric, 'petits blancs' being the name given to lowerclass white settlers in colonies or former colonies, including the United States. Clearly, both Protestants and Catholics in Northern Ireland are white, but in this characterization, the Catholics replace the 'native' populations of colonized countries.

37 See Bruce, Paisley, Religion and Politics in Northern Ireland, 122-3.

38 Bruce, Paisley, Religion and Politics in Northern Ireland, 60-I. 
zeal, who practised tolerance, who believed that their faith was a private affair and that the principal utility of religion was to strengthen the links between neighbours, were a majority among the Protestants of Northern Ireland ${ }^{39}$ Nevertheless, his voice and those of moderate, Northern-Irish Protestants were rarely heard in the French press of the time. As is so often the case in conflict situations, it is the fantastic, spectacular or melodramatic elements that capture people's attention. Even though Ian Paisley represented himself as 'the voice of Ulster Protestantism, ${ }^{40}$ it would be dangerous and unjust to equate Paisleyite doctrine and Ulster Protestantism, and this is precisely what Jacque Amalric reminded his readers: 'Dr Paisley is not representative of Ulster Protestantism'. To support that assertion, Amalric claimed that 'the Christian aristocracy of Northern Ireland, and even more so the industrial aristocracy, often makes a conscious effort to demarcate itself from him. A fair number of pastors even call into question the validity of his doctorate, obtained after many years in one of the most reactionary Protestant universities in the United States. ${ }^{41}$ Similarly, Réforme, the weekly publication of the Eglise réformée de France, distanced itself from Paisleyite ideology by publishing, in March 1971, an article written by the pastor Alan Booth, director of the Christian Aid organization of the British Council of Churches, in which he accused Paisley of fundamentalist fanaticism. ${ }^{42}$ In addition, one reader of Réforme ${ }^{43}$ found it regrettable that 'our press taken as a whole should be so impregnated with Catholicism' and had in consequence not been able to make an adequate distinction between Protestantism in general and Paisley's doctrine. He asked also that 'the Ecumenical Council of Churches should clearly and publicly condemn pastor Ian

Robin Glendinning, 'Le Pays de mes ancêtres', Irlandes parallèle: Deux histoires, deux destins, une attente, ed. Peter Snowdon (Paris: Autrement, collection monde, 1996).

40 See Clifford Smyth, Ian Paisley: Voice of Protestant Ulster (Edinburgh: Scottish Academic Press, 1987). Smyth was a member of the DUP (the political party founded by Paisley).

4I Le Monde, 4 September 1969, 7.

42 Réforme, 13-19 March i971, 10.

43 In a letter published in the correspondence section of the paper, September I97I. 
Paisley and expel him from world Protestantism, which he shames.' After particular events during the conflict - such as the Ulster Workers' strike of 1974 against the Sunningdale Agreement, the demonstrations organized against the Anglo-Irish Agreement of 1985, the notorious incident in the European Parliament in $1988,{ }^{44}$ and the Good Friday peace agreement of 1998 - French journalists again provided their readers with negative images of Ian Paisley, reporting his legendary intransigence and his frenetic activity in opposition to any such compromises. But although his Free Presbyterian Church had attracted few members (according to Steve Bruce, it rose from 0.7 per cent of the non-Catholic population of Northern Ireland in 1971 to 1.2 per cent in 2001, which corresponded to less than I2,000 people), Paisley benefited from wide electoral support: his party, the DUP, became the largest political party in Northern Ireland in 2003, and Paisley subsequently became First Minister in 2007. In the light of their previous reports, how did French journalists react to this success and analyse it?

From the time of his victory in the Assembly Elections of 2003, when the DUP became the largest political party in Northern Ireland, Paisley made a major comeback on the French media scene. He underwent a media makeover: he was no longer regarded as the guru of a cult; now many journalists reminded their readers that he had, as allowed by Protestant tradition, created his own Church, the Free Presbyterian Church of Ulster, and that he had originally been a Baptist. Nonetheless, error and oversimplification remained: Le Point, L'Express and Le Figaro still portrayed him as 'the leader of the Presbyterian Church." Although he was no longer described as a charlatan or a dangerous clown, elements of negative imagery stuck to him. Le Monde presented him as a pastor who was 'intransigent', 'full of bluster', 'vociferous', 'hot-headed', 'a bigot', a 'virulent anti-papist',

44 The expulsion of Dr Paisley from the Parliament after insults directed at Pope John Paul II. The event was reported in the majority of major French dailies: La Croix, 13 October 1988, 6; Libération, I2 October 1988, 33; L'Humanité, I2 October 1988, 8; Le Figaro, 12 October i988, II.

45 See for example, Le Point, is March 2007, L'Express, 9 November 2006, and Le Figaro, 6 October 2005. 
'the king of anathema', and even as 'an anachronistic character sprung from Lutheran pre-history'. The Conservative daily Le Figaro described him as 'the intransigent clergyman', the 'flamboyant Presbyterian [sic] preacher', or as 'the pathetic survivor of the religious wars of another epoch under the guise of politics'. In the Communist paper L'Humanité, he was 'the fundamentalist leader,' 'the inflexible Paisley,' 'that old relic from a different epoch', 'the unyielding Unionist', 'the intransigent Pentecostalist pastor renowned for violent speeches', 'the prophet of vengeance', or 'the rightwing extremist whose MEPs sit beside those of the Front national' - thus Communist readers were given a clearer idea of Paisley's political ideas. The Socialist daily Libération represented him as 'a septuagenarian given to making inflammatory remarks', 'a man mad about God and the Queen', and as 'a religious fundamentalist, the scourge of Catholics'. In the weekly L'Express, he was 'the mad anti-papist', 'the intransigent Presbyterian [sic] pastor', 'the aged fundamentalist'. Certain characterizations appear simplistic, devoid of the element of analysis that one would expect from a journalist, and could even be considered as wilful disinformation. In a 2006 portrait entitled 'Ian Paisley, the gloomy preacher', Le Monde's Jean-Pierre Langellier painted a portrait that was both amusing and unflattering, but above all a complete caricature:

For half a century, Ian Paisley has prompted animal-like caricatures. A thick lower lip, a double chin, short-sighted and wrinkled eyes make him look like a tortoise that never forgets anything. His carnivorous smile turns him into an alligator mad with hunger for power. And the archaic nature of his ongoing struggles from a bygone age evokes a dinosaur. ${ }^{46}$

After the results of the Assembly Elections of 2003, French journalists were quite open about their fears for the future of the Peace Process: Le Monde's London correspondent spoke of 'the worst of scenarios'; ${ }^{47}$ L'Humanités Peter Avis explained that 'this victory is worrying for the future of the Peace Process. His colleague Bernard Duraud pointed out

46 Le Monde, 24 November 2006, 20.

47 Jean-Pierre Langellier, Le Monde, I December 2003, 4. 
that 'nobody could miss the huge silhouette of Paisley, his stentorian voice, his inflammatory sermons and tasteless humour at the negotiating table in 1998 ', but that today, he is really unavoidable. ${ }^{48}$ Le Point's London correspondent compared Paisley to Ariel Sharon, 'whose intransigence he shares. This parallel justifies the anxiety of those supporting the Peace Process. ${ }^{49}$ Similarly, in Libération, Christophe Boltanski expressed doubts as to the survival of peace in Northern Ireland since 'the sworn enemy of the Papists has been resurrected. He holds the key to a process that he publicly despises. ${ }^{50}$ Paisley was represented as an extremely cunning man who, according to Le Monde's Jean-Pierre Langellier, 'has succeeded in turning to his advantage the disenchantment that the Good Friday Agreement created in a Protestant community wracked by doubt and resentment. ${ }^{\text {. } 1}$ In L'Humanité, Peter Avis explained that Paisley had been able to 'attract the votes of a working class that is extremely anxious about the future. ${ }^{52}$ Dorian Chotard of La Croix accused Paisley moreover of exploiting 'people's anxiety to win back seats at Westminster. ${ }^{53}$ According to Libération's Christophe Boltanski, Paisley had been able to take advantage of the collapse of the traditional Unionist party, the UUP: 'with his height of six foot three, his aggressive jaw, his prophetic tones and his huge hands held up towards the heavens, he electrifies working-class Protestants who feel abandoned by the Protestant elite. ${ }^{54}$ Le Figaro's Hervé Amoric went so far as to compare Paisley to 'a poker player' who 'hides his cards until the decisive declaration; before agreeing to form a government with his sworn enemy, he wants to wring concessions from Tony Blair, the most important being an economic settlement. ${ }^{55}$

48 L'Humanité, 20 October 2006, 12.

49 Frédéric Adréani, Le Point, is December 2003.

50 Libération, 29 November 2003.

5I Le Monde, 24 November 2006, 20.

52 L'Humanité, I December 2003, 19.

53 La Croix, I2 March 2007.

54 Libération, 30 March 2007.

55 Le Figaro, 7 March 2007, 4. 
It was only after 2006 that French journalists, who had up until then shown themselves rather pessimistic about the formation of an interdenominational government in Northern Ireland, and had considered Paisley as the main obstacle to an agreement, began to glimpse some hope. Paisley seemed less intransigent towards yesterday's enemy and the proof was that he had, for the first time, shaken hands with the Catholic primate of Ireland, Séan Brady. ${ }^{56}$ Le Monde's Jean-Pierre Langellier waxed ironic, wondering if Paisley '[would] soon be touched by the grace of Him whom he calls on good days the God of forgiveness. ${ }^{57}$ Langellier reminded his readers that Paisley had 'lost an important argument' when the IRA decommissioned its weapons and when Sinn Féin had recognized the Police Service of Northern Ireland, both of which meant that Paisley no longer had any valid reason for opposing power-sharing. L'Express suggested a different explanation:

The elderly fundamentalist seems to have accepted pragmatism: his days are numbered and having been the man who, through his intransigence, has forced the IRA to compromise, it would not displease him to taste the pleasures of being First Minister of an Ulster which remains British. ${ }^{58}$

Le Point also put forward an interesting argument: having struggled fiercely for decades against any attempt to resolve the conflict, Paisley now had the chance to claim the credit for reaching a peace agreement in Northern Ireland:

At almost 8I, the abusive name-caller who has led the DUP to victory is faced with a choice that will decide his place in History: either he gives in to his natural inclination which has earned him the nickname 'Mr No', or he transfers himself from the Middle Ages to the twenty-first century and thereby becomes the person through whom peace has been reached. ${ }^{59}$

56 Reported in Le Monde, 24 November 2006, L'Humanité, 12 October 2006, Libération, 7 March 2007, Le Point, is March 2007.

57 Le Monde, 24 November 2006, 20.

58 L'Express, 9 November 2006.

Le Point, is March 2007. 
When Paisley agreed to power sharing, French journalists celebrated 'the epilogue to a public life lasting half a century, which has consisted of refusals, vetoes and complete lack of engagement. ${ }^{60} \mathrm{Le}$ Monde's correspondent ironically remarked that the last time Paisley had said yes, had been at his wedding, fifty years earlier. ${ }^{61}$ Libération put forward three different arguments to explain Paisley's decision: according to Sabine Limat, Paisley had no alternative to accepting power sharing because he was in a blind alley. To say 'no' would mean the permanent dissolution of the Northern Ireland Assembly and the loss of his salary. ${ }^{62}$ On the other hand, her colleague Karine Le Loet, the magazine's correspondent in London, attributed Paisley's decision to 'a softening of the pastor's stance. ${ }^{63}$ Christophe Boltanski felt this decision should be credited to the IRA, which 'had deprived Paisley of his main arguments for refusing to apply the peace agreement. ${ }^{34}$ The same explanation can be found in La Croix: 'the radical change in the Republican movement explains it in large measure [...] The DUP leader had fewer and fewer arguments to oppose power sharing. ${ }^{\text {'65 }}$ Le Figaro, for its part, preferred to emphasize the pastor's cunning: according to Cyril Hofstein, 'cunning and sly, the man who in the past blocked everything has managed, in order to survive, to transform himself into the man who opens doors. ${ }^{366}$

In March 2008, one year after assuming the position of First Minister of Northern Ireland, Paisley announced his retirement. For the first time in forty years, the reactions of the French press were favourable toward him. Le Monde's Marc Roche stated that 'the virtues of compromise exhibited by Ian Paisley have won unanimous praise for him. Admiration wins out

60 Rémi Godeau in Le Figaro, 8 May 2007, 23.

6I Jean-Pierre Langellier, Le Monde, 16 October 2006, 20.

62 Libération, in November 2006.

63 Libération, 9 May 2007.

64 Libération, 30 March 2007.

65 Eric Albert, La Croix, 28 March 2007.

66 Le Figaro Magazine, 31 March 2007, 36. 
easily over bad memories. ${ }^{67}$ Le Figaro's Sébastien Martin wrote of 'the end of a political era: "Dr No" is leaving amid the praise of the whole world because he brought about peace. ${ }^{68}$ L'Humanités Peter Avis did not hide his esteem for a 'pastor converted to peace. ${ }^{69}$ The special correspondent of L'Express, Jean-Michel Demetz, was unstinting in his admiration:

Is it his extreme old age or the discreet influence of his wife that has set Paisley on the road to redemption? Basically, it matters little, because the result is there: the paramilitaries have disarmed, the British army has withdrawn, and Belfast city centre is as lively as are other cities of the British Isles. ${ }^{70}$

Similarly, in the Catholic daily La Croix, Eric Albert wrote that 'Ian Paisley can allow himself the satisfaction of work accomplished, and this man will enter History as the person who made peace in Northern Ireland. ${ }^{71}$

A character like Ian Paisley can only be understood if he is seen in the context of the evangelical Protestant movements in Northern Ireland. In defence of French journalism, this would not have been an easy task unless one had at one's disposal the indispensable theological facts which would allow understanding of his eschatology, the characteristics of his Church and his political position. Yet is it defensible that, for almost forty years, Paisley was presented to French readers as the guru of a dangerous sect, a clown with an anti-Catholic obsession given to flirting with paramilitary violence, as a cunning charlatan, an intransigent sectarian demagogue, or as a character from a different era? This negative image is certainly attributable to the fact that Paisley ceaselessly rubbished and rejected many of the values to which the French are attached: republicanism, Catholicism, a united Europe, social liberalism, and ecumenism. There were, of course, other contributing factors: unlike Republicans, the Unionist and Loyalist leaders had never felt the need to communicate with journalists, as was pointed out

67 Le Monde, 7 March 2008, 8.

68 Le Figaro, 2 June 2008, 8.

69 The title of Peter Avis's article in L'Humanité, 7 March 2008.

$70 \quad$ L'Express, 21 May 2008.

71 La Croix, 6 March 2008, 6. 
by Le Monde's Henri Pierre as early as 1981: 'either the Protestant Loyalists put their views across badly, or else they do not feel the need to justify themselves to French public opinion. ${ }^{72}$ Similarly, the welcome given to French journalists in loyalist areas was far from warm, as Le Monde's Jacques Amalric pointed out in 1969:

After Catholics, journalists are undoubtedly top of the Orange blacklist. Their nationality matters little. As the Orangemen feel instinctively that all the facts are not in their favour, and are, in fact, far from being so, hence Protestant extremists reply to the press solely with insults, threats and sometimes gunfire. ${ }^{73}$

Numerous special correspondents have reported how they were violently turned away by the security forces from Orange parades or expelled from Paisleyite demonstrations. As Alan Parkinson understands it, the deeplyheld belief of the loyalist leaders in the moral supremacy of their cause earned them their media isolation, since they did not feel the need to justify their political vision. ${ }^{74}$ The attitude of the Loyalist community toward foreign journalists certainly influenced the latter's reporting. In addition, Ian Paisley purposely nurtured this negative image. In a series of tapes recorded in 1980 , he explained:

If you are going to be godly men in a godless age, you will be persecuted. When this church ceases to be hated, and when this church ceases to be reviled, then the preacher is finished. He can pack it up and go home forever. But as long as men hate us, as long as men revile us, and as long as newspapers write against us, praise God, we'll be doing something. ${ }^{75}$

Through their multiple portraits and anecdotes, journalists have assisted the French people in forming some impressions of the man who became First Minister of Northern Ireland in 2007. Ultimately, however, it would

72 Le Monde, 30 July i981, 2.

73 Le Monde, i9 August 1969, leading article.

74 Alan Parkinson, Ulster Loyalism and the British Media (Dublin: Four Courts Press, 1998), 30-7.

75 Ian Paisley, Side I Tape 3, 'This is My Life', Belfast, Martyrs' Memorial Publications, 1980, quoted in Bruce, Paisley, Religion and Politics in Northern Ireland, 2009, 163. 
appear that journalistic practice has meant that the views the French have of him are incomplete and indistinct, distorted somewhat by misunderstandings of his political and religious identity. ${ }^{76}$

76 I wish to thank the Research Committee of the University of Buckingham which awarded me a Dennison Research Grant to finance this project and Professor Graham Gargett, University of Ulster, for his help with the translation from French into English. 


\section{The Enfant Terrible of French Letters: Michel Houellebecq}

Rarely has a writer, even a French writer, polarized public opinion in the way that Michel Houellebecq has done for the past two decades. Since the publication of his biography of Howard P. Lovecraft, subtitled significantly Contre le monde, contre la vie, in I99I, he has produced work that is both counter-cultural and exceptionally controversial. It would be difficult to find a more appropriate or controversial subject in terms of the public imagination, in France and in Ireland, than this enfant terrible of French letters.

Les Particules élémentaires, published by Flammarion in 1999, and in English translation as Atomised in 2000, brought Houellebecq to public attention for his negative portrayal of the sexual revolution, swingers' clubs and unbridled permissiveness that apparently leave people feeling even more empty than when they live in isolation from the world. It also made the daring prediction of the possibility of human cloning - this at the end of a novel in which the ambience of hopelessness and desperation is omnipresent. Finally, a French writer seemed to have emerged who was capable of following in the footsteps of Sartre and Camus. Existence is absurd; there is no God; it is impossible to find meaning; how can one live in such uncertainty? These are the type of issues raised in Houellebecq's novels and poetry. In his biography of Lovecraft, he wrote: 'L'âge adulte, c'est l'enfer. [...] Principe de réalité, principe de plaisir, compétitivité, challenge permanent, sexe et placements [...] pas de quoi entonner des alléluias ${ }^{1}$ [Adulthood is hell. [...] It's all about dealing with reality, pleasure, competitiveness. It's a constant challenge to reconcile your sexual longings with

I Michel Houellebecq, H.P. Lovecraft. Contre le monde, contre la vie (Paris: 'J'ai lu', I999), I6-I7. (My translation.) 
professional security [...] it's certainly not something that would have you chanting hymns of joy].

The origin of this rather fatalistic view of adult life bringing nothing but torment might be traced back to his childhood and adolescence spent with his paternal grandparents in whose care his parents (his father was a mountain guide and his mother an anaesthetist) abandoned him in order to indulge their dream of sexual liberation. This would mark the beginning of a strained relationship, especially with his mother, who so resented Houellebecq's criticism of her behaviour in his writing and public interviews that she replied with a controversial four-hundred-page memoir in which she attempted to justify herself. ${ }^{2}$ For the first time perhaps, the writer gained public sympathy, as the mother showed herself in an even worse light than he had painted her. The problematic mother-son relationship has undoubtedly influenced Houellebecq's view of the world and impacted negatively on his view of human relationships, in particular with women. ${ }^{3}$

Asked by Susannah Hunnewell about his literary precursors during a 2010 interview with The Paris Review, Houellebecq acknowledged his attachment to Baudelaire, Nietzsche, Schopenhauer and Dostoyevsky, while also admitting an admiration for the Romantic poets Hugo, Vigny, Nerval, Verlaine and Mallarmé. But Pascal was the shock of his life:

2 Lucie Ceccaldi, L'Innocente (Scali, 2008). In an interview surrounding the book, the then eighty-three-year-old had the following message for her son: 'Avec Michel Houellebecq, mon fils, on pourra commencer à se reparler le jour où il ira sur la place publique, ses "Particules élémentaires" dans la main, et qu'il dira: "je suis un menteur, je suis un imposteur, j'ai été un parasite, je n'ai jamais rien fait de ma vie, que du mal à tous ceux qui m’ont entouré. Et je demande pardon"' [I might consider speaking once more to Michel Houellebecq, my son, the day he goes into the public square with a copy of Atomised in his hand and says: 'I am a liar; I am an impostor; I was a parasite who never did anything in his life other than hurt those who surrounded me. And I beg forgiveness.'] <http://www.2ominutes.fr/article/228170/Culture-La-mere-deHouellebecq-ecrit.php>. Accessed I3 May 20 I2.

3 Houellebecq is far from unique in producing a negative picture of his mother in a barely fictionalized form; Hervé Bazin's Vipère au poing is equally scathing of maternal inadequacies. 
I was fifteen. I was on a class trip to Germany, my first trip abroad, and strangely I had brought the Pensées of Pascal. I was terrified by this passage: 'Imagine a number of men in chains, all under sentence of death, some of whom are each day butchered in the sight of the others; those remaining see their own condition in that of their fellows, and looking at each other with grief and despair await their turn. This is an image of the human condition.' I think it affected me so deeply because I was raised by my grandparents. Suddenly I realized that they were going to die and probably soon. That's when I discovered death. ${ }^{4}$

Behind the indifferent, impatient and rather tetchy exterior, one is often struck by the vulnerability of Houellebecq. While he plays up his public persona, deliberately courting controversy, as for example in his excoriation of the falsity of feminism and all the other political liberal movements of the 1960 s, or his drunken contention in an interview during the lead-up to the publication of his novel Platform that: 'Islam is the most stupid and murderous of all religions', one nevertheless has the impression that he is desperately seeking to reach out to his readers, to share some awful truths with them. The fact that the comment about Islam came only days before the Twin Towers attack of 9/II, made Houellebecq into something of a cause célèbre. An article entitled 'Agent provocateur - Literary rock star' in The Observer newspaper noted: 'Suddenly, in the wake of terrorist attacks, Houellebecq became a seer and prophet whose theses about the decline of Western civilisation now seemed to carry deadly truths."

A question that often comes to mind when reading Houellebecq's fiction or public pronouncements is whether he deliberately sets out to cultivate notoriety, or is he sincere in what he says. In France, he has been viewed as someone who manipulates the media in order to boost book sales. Whereas he has railed against those who accentuate the autobiographical dimension of his novels, it is impossible for anyone with even the

4 'Michel Houellebecq, The Art of Fiction', interviewed by Susannah Hunnewell, The Paris Review No. 206, 20 September 2010. <http://www.theparisreview.org/ interviews/6040/the-art-of-fiction-no-206-michel-houellebecq $>$. Accessed I3 May 2012.

5 Andrew Hussey, 'Agent provocateur - Literary Rock Star', The Observer, 6 November 2005 . 
vaguest knowledge of his background to fail to see that they contain barely refracted versions of his life. And in some ways, that is what gives them their charm. When questioned about how critics focus on his biography in order to explain his work, Houellebecq argued that such an approach 'denies what is the essential trait of fiction writing, namely, that the characters develop by themselves. In other words, you start with a few real facts and then you let the thing roll with its own momentum. And the further along you get, the more likely you are to leave reality behind altogether.' There is undoubtedly some truth in these assertions but, at the same time, the personality of the writer, his interests and obsessions, also drive certain fictional narratives and hence one can never completely disregard the biographical dimension.

Houellebecq's success can be gauged by the fact that 300,000 copies of the first, more expensive, editions of Atomised and Platform were sold in France. When one adds the sales of the 'éditions de poche' and the translations into over thirty-six languages, one begins to appreciate that this is an author who is read widely and who holds a massive appeal for the public imagination. Atomised was strongly tipped for the Prix Goncourt in 1999, but was overlooked, prompting the outrageous allegation by Houellebecq that he did not have a budget big enough to buy off the judges! Platform suggested that global sex tourism was the next logical extension of capitalism and the novel is shot through with many crude gratuitous sex scenes. It concludes with a gun attack by Muslim terrorists on a tourist hotel in Thailand which claims the life of Valerie, partner of the main character Michel. Reflecting on what has happened, Michel observes:

To the end, I will remain a child of Europe, of worry, and of shame. I have no message of hope to deliver. For the West, I do not feel hatred; at most I feel a great contempt. I know only that every single one of us reeks of selfishness, masochism, and death. We have created a system in which it has simply become impossible to live; and what's more, we continue to export it. ${ }^{7}$

7 Michel Houellebecq, Platform, trans. Frank Wynne (London: William Heinemann, 2002), 360-I. 
But, while that character is disgusted with Western capitalism, he finds the actions of the terrorists equally, if not more, reprehensible. Understandably, the following lines from the novel did not exactly endear him to Muslims either: 'Every time I heard that a Palestinian terrorist, or a Palestinian child or a pregnant Palestinian woman had been gunned down in the Gaza Strip, I felt a quiver of enthusiasm at the thought that it meant one less Muslim.'

Comments like these, appearing as they did in the aftermath of $9 / \mathrm{II}$, albeit in a work of fiction, naturally inflamed Muslims and non-Muslims alike. A Jordanian banker whom Michel engages in conversation offers the following assessment: 'The problem with Muslims, he told me, was that the paradise promised by the prophet already existed here on earth; there were places on earth where young, available, lascivious girls danced for the pleasure of men, where one could become drunk on nectar and listen to celestial music $[. .].]^{\text {,9 }}$ This would appear to be a rather narrow interpretation of what constitutes paradise, but it is consistent with the general tone of Platform which, in the view of many critics, is a vastly inferior novel to Atomised. It is important to quote certain passages from it in order to give a flavour of just how depressing Houellebecq's world view can be. The opening line, in an echo of Camus' L'Étranger, reads simply: 'Father died last year.' Whereas in the first line of that novel, Meursault, the Camus hero or anti-hero, announces in a rather unemotional manner the death of his mother the previous day, he does reveal some affection for the deceased woman. The atmosphere of L'Etranger is not irrepressibly bleak, as is the case with Platform. Meursault derives enjoyment from simple things like the feel of the sun on his back, swimming in the sea, having sex with his girlfriend Marie, breathing in the fresh smell of her hair, admiring the pretty dresses she wore. However, Michel is unrelentingly critical of his father: 'As I stood before the old man's coffin, unpleasant thoughts came to me. He had made the most of life, the old bastard: he was a clever cunt.' ${ }^{10}$ Michel is also strident in his criticism of France: 'I was living in a country 
distinguished by placid socialism, where ownership of material possessions was guaranteed by strict legislation, where the banking system was surrounded by powerful state guarantees. ${ }^{\text {'1 }}$

Throughout Platform, one is bombarded with critical comments about the emptiness induced by Western capitalism, the only escape from which, according to Michel, can be found in sex. But the ultimate reality, as Houellebecq discovered when reading Pascal at the age of fifteen, is death, and life is just a preparation for that frightening journey into the unknown. There is clearly far too much polemic in Platform, with the novel form being used as a means of airing the author's controversial views, rather than coming to terms with how people like Michel deal with the issues that confront them, such as despair and solitude. Gavin Bowd's assessment that 'Houellebecq is the Karl Marx of the lonely,' ${ }^{12}$ is undoubtedly astute, provided that one points out the tendency to lose sight of the plight of his characters in order to follow some personal agenda.

Because of what was perceived to be the declension in his work in Platform, it came as something of a surprise to learn last year that his latest novel, La Carte et le territoire, had won the Goncourt. Such an honour being bestowed on a writer whose disregard for sacred French customs and institutions, as well as his disdain for the literary Establishment, demonstrates the extent to which his moments of perceptive genius are impossible to deny. This prestigious prize will serve to increase Houellebecq's already phenomenal popularity in France and abroad and may mean that more serious-minded academics will explore his work in further depth. It is not without significance that the writer explained the change of tone in his latest novel, one that is brought on by the calming effect induced by

II Houellebecq, Platform, 25.

I2 Gavin Bowd, 'The World of Michel Houellebecq', in Eamon Maher and Eugene O'Brien (eds), La France face à la mondialisation/France and the Struggle against Globalization (Lewiston/Queenston/Lampeter: The Edwin Mellen Press, 2007), $115-27,117$. This is a very useful essay on Houellebecq by an academic who is also the translator of his Goncourt-winning novel, La carte et le territoire (2011). 
writing a book about the approach of death: 'You can't be a crazy rebel in the face of death, it's not a fitting attitude.'13

The considerable hold that Houellebecq exerts on the public imagination has a marked Irish angle. Many people will be aware that the writer spent a number of years living in Ireland, on Bere island off the west coast of Cork. In a BBC documentary made in July 200 (but never broadcast), he was asked about his decision to move to Ireland and he explained:

Ireland is the only country where I cried, just seeing the landscape. The landscape in itself was alive. Yes, it was possible to be deeply moved by the different lights in the landscape. With other landscapes you can be highly impressed, but you don't cry. Some landscapes can turn you into a megalomaniac. But this is not the case with the Irish landscape. It makes me want to cry, but not sadly. ${ }^{14}$

The vividness of the Irish landscape is among the things that attract the scientist Michel, one of the main characters of Atomised, to Clifden in county Galway at the end of that novel. Having just lost Annabelle, the love of his life, Michel seeks to bring his research and his life to a conclusion. In the Book of Kells, he detects something beyond the insidious individualism that affects the Western world, and which has even made its way to one of the furthest western outposts, Connemara. By applying quantum physics to biochemistry, Michel believes that human cloning might well be possible, which leads to the even more radical contention: 'that humanity must disappear, that humanity must give way to a new species which was asexual and immortal, a species which had outgrown individuality, individuation and progress. ${ }^{15}$ This vista was envisaged by Michel as the world stumbled towards the beginning of the third millennium, a time of reflection on the past and of uncertainty about what the future might hold. One of the thoughts that come to Michel as he walks along the lanes near Clifden is

I3 Quoted by Tim Martin, 'The Michel Houellebecq Phenomenon', in The Telegraph, 29 September $201 \mathrm{I}$.

I4 Cited by Gavin Bowd, 'The World of Michel Houellebecq', I2O.

Is Michel Houellebecq, Atomised, trans. Frank Wynne (London: Vintage, 200I), 37 I. 
the following: 'In cemeteries all across the world, the recently deceased continued to rot in their graves, slowly becoming skeletons. ${ }^{16}$

When he first arrives in Clifden, Michel meets an Englishman, Walcott, who tells the French visitor about the huge changes that have taken place in Ireland:

'Most of them around here are Catholics', he said. 'Well, that's all changing now. Ireland is just coming into the modern world. Quite a few hi-tech companies have set up here to take advantage of tax breaks and the low social security payments. Round here, there's Roche and Lilly. And Microsoft, of course: every kid in the country dreams of working for Microsoft. People don't go to mass as much as they used to, there's more sexual freedom than there was a couple of years ago, there are more nightclubs, more anti-depressants. The classic story $\left[\ldots . . .{ }^{17}\right.$

Did Houellebecq detect and expose some of the more sordid aspects of the Celtic Tiger when it was beginning to take root in Ireland? Perhaps it was comments like these that inspired former-President Sarkozy to call into question Ireland's generous corporation tax regime in 20 II. While one might question the desire of all young Irish people to work with Microsoft, there is a certain truth in the contention that Ireland lost its soul, or to use more secular language, lost its way, to some extent during the boom years. The blind embrace of individualism and materialism clashed with the mystical quality of the landscape, as Walcott also points out:

'I'm an atheist myself, always have been, but I can understand why they're Catholic here. There's something very special about this country. Everything seems constantly trembling: the grass in the fields or the water on the lake, everything signals its presence. The light is soft, mutable. You'll see. The sky itself is alive ${ }^{, 18}$

It is surely significant that Houellebecq should have described in such detail the unique Irish topography in his best-selling novel. In the passage just quoted, there is a genuine appreciation of how contemplating such a vista can help people to ponder the eternal questions, to interrogate the

Houellebecq, Atomised, 353 .

Houellebecq, Atomised, 349-50.

I8 Michel Houellebecq, Platform, 350. 
meaning of life, the origins of happiness, the importance of love. Before departing for Ireland, Michel lost his much-loved Annabelle, a victim of a permissive culture that placed inordinate emphasis on sex. When, as a young man, Michel was not ready to commit to a sexual relationship with her, Annabelle took up with the son of the owner of a commune they visited on the suggestion of Bruno, Michel's brother. This began a series of failed love affairs, abortions and, ultimately, unhappiness. When she is reunited with Michel, she explains her disillusionment with the sexual revolution: 'In the end, it was too hurtful to know they [her lovers] thought of me as just another piece of meat. ${ }^{{ }^{19}}$ This type of sensitive probing of a wasted life is what gives Atomised a quality that is lacking in certain other works by Houellebecq. On the official Houellebecq website, there is the following témoignage by Victoria Deodato in relation to Annabelle:

Annabelle a été ce corps somptueux, cet amour raté, et ce cadavre abandonné, 'vidée comme un poulet' par les avortements. Une beauté pour rien. Une vie pour rien. Un amour pour rien.[... Elle a eu des expériences diverses. Elle aurait pu ne pas s'ennuyer. Mais la liberté ne comble pas le vide.

[Annabelle was this sumptuous body, this failed love, this abandoned corpse, 'emptied from the inside like a chicken' by abortions. Her beauty did not serve any worthwhile purpose. The same with her love [...] She underwent various experiences. She might have been able to solve her boredom in different ways. But freedom does not fill the vacuum.]

Houellebecq writes about sex in a non-glorifying way. His characters reflect, to some degree, the experiences and convictions of their creator. They are restless, uneasy in their skin, searching for a meaning that constantly slips out of their reach. Towards the end of Atomised, Walcott observes that there was 'something monstrously sad' about Michel. ${ }^{20}$ One has the same feeling when reading Houellebecq. He repels and attracts in equal measure. One detects both genius and superficiality in his novels. Michel's choice of Connemara as a location to end his life allows Houellebecq to

Atomised, 364 . 
movingly reflect on the vacuity of materialistic and hedonistic society in Ireland and France. Ireland is treated as a last outpost where traditional values are ceding to a more permissive society which in turn must give way to a cloned future which excludes reproductive strife. Ireland is thus an appropriate locale from which to underline Houellebecq's critique of Western civilization.

The Map and the Territory, Houellebecq's latest novel, may be the turning point in a literary output that has been uneven to say the least. It is calmer, more mature, the work of an artist whose anger has not been quenched, so much as controlled and pacified. Gone are the gratuitous sex scenes, the compunction to shock, the interjection of the author's own views that are placed in the mouths of characters. There are many obvious postmodern techniques employed in it: for example, Michel Houellebecq is a central character in his own work, a man who is befriended by the photographer/artist Jed Martin, who approaches him with a view to writing a Preface for his latest collection. On hearing this, Jed's father observes: 'He's a good author, it seems to me. He's pleasant to read, and he has quite an accurate view of society. ${ }^{21}$ This is a clear attempt to poke fun at the normal public perception of Houellebecq as someone who prefers sensationalism to the truth, and who deliberately provokes his readers and detractors with outlandish claims and descriptions. Most of the other insights about Houellebecq in The Map and the Territory are far from complimentary. For example, when he goes to visit the writer in Ireland, Jed finds him living alone in relative squalor, 'a tortured wreck who was now gently nodding his head in front of him while devouring slices of pâté de champagne, and who had manifestly become indifferent to anything connected to a loving relationship, and most probably any kind of human relationship. ${ }^{22} \mathrm{He}$ drinks copious amounts of wine, while talking animatedly about the artistic

2I Michel Houellebecq, The Map and the Territory, trans. Gavin Bowd (London: Vintage, 2012), 9. 
process and scratching the eczema on his foot: 'I'm rotting on the spot and no one gives a damn, no one can do anything to help me. ${ }^{23}$

This type of self-referential obsessiveness might become tedious if it were not accompanied by an apparently genuine desire on the part of Houellebecq to better understand his own character and vocation in life. $\mathrm{He}$ and Jed exchange ideas about their art. There are certain statements attributed to Houellebecq that capture his approach to the novel in a successful manner. In one instance, he declares: 'It's impossible to write a novel [...] for the same reason that it's impossible to live: due to accumulated inertia. ${ }^{24} \mathrm{On}$ another occasion, we read: 'You never decide to write a novel, he [Houellebecq] had added; a book, according to him, was like a block of concrete that had decided to set and the author's freedom to act was limited to the fact of being there, and of waiting, in frightening inaction, for the process to start by itself.' ${ }^{25}$ The fact that these insights are shared with the man who is about to paint his portrait is indicative of the writer's awareness of the power of art (and painting in particular) to reveal some inner truths that one might prefer to keep secret. The artist observes things that others miss. Hence, as Jed is leaving his Irish home, somewhat worse for wear, after consuming copious amounts of wine, Houellebecq says to him:

'You know, I realise what you're doing, and I know the consequences. You're a good artist - without going into detail one could say that. The result is that while I've been photographed thousands of times, if there's an image of me that will last for the centuries to come, it will be your painting. [...] You see, I take painting seriously. ${ }^{26}$

The Map and the Territory is Houellebecq's attempt at exploring the unique power of art to transform and transcend reality. Jed Martin's career unexpectedly takes off when an exhibition of his detailed photographs of Michelin maps makes him an overnight celebrity. His vocation revealed itself to him when looking at one of these maps of the Creuse and Haute 
Vienne region, which he considered 'a great aesthetic revelation'. In his view, 'This map was sublime. ${ }^{27}$ However, as his career progressed, he found that as long as he was merely portraying objects, photography was perfect: 'But when I decided to take as my subject human beings, I felt I had to return to painting. ${ }^{28}$ These revelations are made during the first of his two visits to Ireland. In fact, it could be claimed with certain degree of justification that some of the most essential moments in Houellebecq's fiction are situated in the Emerald Isle. In addition to Michel's epiphany in Atomised, or the comments by Walcott in the same novel, many of the key exchanges of The Map and the Territory are equally located in an Ireland that seems to induce self-revelation and reflection. Jed notes the photographs of eminent visitors to Shannon airport as he arrives in the terminal - American Presidents and Popes in the main - and is struck by the fact that one of the celebrities, John F. Kennedy, was captured, not by a photograph, but by a painting, and a rather poor one at that:

All the same, there was in the painting a sort of human and symbolic truth about John Fitzgerald Kennedy that was achieved by none of the photos in the gallery even that of John Paul II, although in good shape, taken on the steps of the plane as he opened his arms wide to salute one of the last Catholic populations in Europe. ${ }^{29}$

The relationship between Ireland and one of the foremost literary figures in France today must owe something to the parenté d'esprit [spiritual relationship] that exists between the two countries. Houellebecq has acknowledged his fascination with Ireland on numerous occasions and his decision to come and live in the country was no mere coincidence. Inspired by the landscape, but also perhaps by the way in which his celebrity status meant little or nothing to the local population, who allowed him to carry on his life in an unobtrusive and reclusive manner, there is an enduring connection between the country and writer; it persists even though Houellebecq is no longer resident on Irish shores. The Map and 
the Territory marks a new stage in the writer's evolution. As was pointed out by Tim Martin: 'Houellebecq's fifth book is not only his best for years but very likely his best ever, a serious novel about ageing and death that also employs its author's trademark lugubrious wit towards some delicious exercises in satire and self-parody. ${ }^{30}$ He no longer feels the need to shock or anger his readers, contenting himself with painting a canvas of the world which, while rather pessimistic on the whole, still has the capacity to hold one spellbound. There are also moments of real insight, like when Jed, having lived as a recluse for many years, suddenly realizes that the capitalist project had failed:

you were living in an ideologically strange period, where everyone in Western Europe seemed persuaded that capitalism was doomed, and even doomed in the short term, that it was living through its very last years, without, however, the ultra-left parties managing to attract anyone beyond their usual clientele of spiteful masochists. A veil of ashes seemed to have spread over people's minds. ${ }^{31}$

Just as he may have been prescient in the potential threat posed by Muslim discontent immediately prior to 9/II, Houellebecq could well be correct about the collapse of the neoliberal and capitalist agendas. He has a Cassandra-like quality to predict the future and to suffer from the disbelief of those whom he seeks to alert. He exercises a paradoxical influence on the public imagination: people either love him or excoriate his message. But he continues to attract readers in huge numbers and may, with the publication of The Map and the Territory be able to realize the ambition expressed to Susannah Hunnewell in The Paris Review:

'For the moment my desire to be loved is enough to spur me to action. I want to be loved despite my faults. It isn't exactly true that I'm a provocateur. A real provocateur is someone who says things he doesn't think, just to shock. I try to say what I think. And when I sense that what I think is going to cause displeasure, I rush to say it with real enthusiasm. And deep down, I want to be loved despite that. ${ }^{, 32}$

30 Martin, 'The Michel Houellebecq Phenomenon'.

3I The Map and the Territory, 269-70.

32 'Michel Houellebecq, The Art of Fiction'. 

PART III

The Public Spheres: Interventions and Interpretations 



\section{Towards an Irish Republic: Cultural Critique and an Alternative Paradigm}

To say that Ireland, as a republic, is at a point of crisis is a truism. PostCeltic Tiger Ireland is very much devoid of capital - financial, political and cultural. Financially, from 2008 to 2013 , Ireland was under de facto rule from the EU, the ECB and the IMF; a cash bailout was required to run the country, and government spending was subject to quarterly review of its national accounts if a flow of capital was to be guaranteed. Politically, Ireland has been seen as corrupt in the wake of the release of the two tribunal reports, the Mahon Report ${ }^{1}$ in $201 \mathrm{I}$, and the Moriarty Report ${ }^{2}$ in 2012, while issues of moral corruption arise in the Murphy and Ryan reports into clerical child abuse. The overall effect of such shocks to the body politic in Ireland has been seismic.

Under a specific act of law, the Tribunals of Enquiry Act of I92I, the Oireachtas, the Irish parliament, sets up such bodies. They do not have a judicial function per se; their role is inquisitorial as they can enforce attendance and the production of documents. As an agent of society, they can bring to the surface that which remains hidden. The Mahon tribunal was set up in 1997 to inquire into suspected corruption of the planning process in Dublin as suspicions had been raised about payments by developers to politicians. And its findings were stark: 'throughout that period, corruption in Irish political life was both endemic and systemic,', and very high and Payments (Dublin: Government Stationery Office, 2012).

2 M. Moriarty, Report of the Tribunal of Inquiry into Payments to Politicians and Related Matters. 2 volumes (Dublin: Government Stationary Office, 2006; 2011). 
office-holders were seen as part of this process. The Mahon report runs to 3,270 pages and is a comprehensive account of the corruption that prevailed in planning circles in the Ireland of the 1980 s and 1990 s. Set up to investigate the financial affairs of Charles Haughey, a former Taoiseach of Ireland, and a Fine Gael minister, Michael Lowry, Volume I, dealing with the Haughey case, found that from 1979 to 1996 , he received £9,106,369.17, ${ }^{4}$ exclusive of salary and expenses. The tribunal concluded that Mr Haughey, in return for such payments, 'acted with a view to intervening improperly in a pending tax case of great magnitude's involving Ben Dunne.

The second report of the Moriarty tribunal deals with Michael Lowry, Minister for Transport, Energy and Communications, and his dealings with Ben Dunne and Denis O'Brien. Once again, the work is voluminous - 704, I,7I 4 and 68I pages respectively - and once again, the points are well-made. In his dealings with Dunne, in attempting to influence a rent increase on a property owned by Dunne, Lowry was deemed to be 'profoundly corrupt to a degree that was nothing short of breathtaking,' because, had this deal gone through, it would be immune from further scrutiny 'having been obtained through a quasi-judicial process. ${ }^{7}$

So, it would seem that in our republic, the great and the good of society are brought to book for their misdeeds. It would seem that the law-givers are subject to their own laws in a manner analogous to that cited by Jacques Rancière when he spoke of Plato's Republic and how the relationship between the politicians and the people does not signify 'any relationship of domination, no cracy in the political sense. ${ }^{8}$ In this ideal republic, 'the magistrates, who have gold in their souls, cannot have any material gold in their hands, means their own share can only be the common lot.' And it would seem that by probing and analysing corruption,

Moriarty, Report of the Tribunal of Inquiry, Volume I, 544 .

Moriarty, 545 .

Moriarty, Report of the Tribunal of Inquiry, Part II, Volume I, 510.

Moriarty, 419.

8

Jacques Rancière, Disagreement: Politics and Philosophy (Minneapolis: University of Minnesota Press, 1998), 65. 
the mentalité of the Irish Republic is attempting to ensure that this is the case. However, this chapter will argue that this is not the case, and that these tribunals merely offer a semblance of critique, as there is no further role for their findings in the Irish socio-political system. They were set up as stand-alone enquiries, and are as such detached from issues of crime, prosecution and punishment.

There is, therefore, another perspective that can be taken on these tribunals. No politician has served a lengthy jail sentence although Ray Burke and Liam Lawlor spent some time in jail for obstructing the tribunals; no politician was forced to resign from a position of power (though some have since resigned from their political parties, albeit with all of their expenses and emoluments intact); while both Lowry and Haughey made tax settlements on foot of disclosure of their accounts, there were no punitive fines imposed as this was outside of the remit of the tribunals. Given that both processes started in 1997 , there is a strong likelihood that evidence will have been destroyed, that memories will have become less clear and that witnesses will have succumbed to ill-health or death. The result of this is that the third area of crisis, that of cultural capital in the public imagination, is very much in the debit column as well.

What we have seen in operation in the discourse of the Tribunals is what Jacques Lacan would term the symbolic order, the order of symbols, of language, of linguistic structure into which we are, to use Lacan's words 'born a second time', namely, 'the symbolic order constituted by language.' ${ }^{10}$ Lacan says that 'what is refused in the symbolic order re-emerges in the real.' ${ }^{11}$ Basically, the real of these is that it took fourteen years, $€ 400$ million and over 6,367 pages to say that politicians and businessmen need to be watched closely; that unregulated relationships between politicians and lobbyists are a bad idea; and that the world of business is one which will take what advantage it can. As a term of cultural critique, the Lacanian

IO Jacques Lacan, Ecrits: The First Complete Edition in English, trans. B. Fink, R. Grigg and H. Fink (London: W.W. Norton, 2006), 37 I.

II Jacques Lacan, Seminar 3 The Psychoses, trans. J-A. Miller (London: Routledge, 1993), I3. 
real sheds some light on our political culture, and I would argue that this is no accident. Political thinking about politics is never able to do more than summarize as opposed to synthesize: as an Irish government minister noted recently, it is impossible to plan because events are so fluid in terms of the financial crisis. I would suggest that the specific branch of continental philosophy that is literary and cultural theory, which can fuel the public imagination, provides a useful lens through which to view matters political and financial from a fresh perspective, and I would further suggest that such theory is, by and large, French in origin.

My own view is that an infusion of French intellectual thought is required if our public imagination is to become sufficiently self-aware and self-confident, to endorse a sense of what I would call 'messianic republicanism. I am not referring to the brand of republicanism that has been prevalent in Ireland over the past thirty years, as embodied by Sinn Féin, the Provisional IRA and the numerous offshoots of that organization - the Real IRA, the Continuity IRA - but rather to the democratic philosophy enshrined in French republicanism, encapsulated in the motto: Liberté, égalité, fraternité.

However, while I will refer to political matters, this is not a political discussion; nor is it a purely philosophical one. Instead I will probe 'philosophy's relation to politics' and ask 'how are we to name or prescribe it. ${ }^{12}$ I shall attempt to show that, in the words of Alain Badiou, philosophy provides a 'discussion space ${ }^{13}$ to probe different aspects of the political. As he puts it:

Philosophy would constitute a discussion space for these instances by locating their different types. Overall, philosophy would be a formal apprehension of States and instances of politics by exposing and pre-elaborating the types in question in accordance with possible norms. ${ }^{14}$

I2 Alain Badiou, Metapolitics (London: Verso, 2005), 85.

I3 Badiou, Metapolitics, 86.

I4 Badiou, Metapolitics, 86. 
For Badiou, the equation between state and political typology, between state and the name democracy, is a connection that needs to be critiqued, and philosophy provides the space for such a process. One of the interesting conclusions at which he arrives in his book, Metapolitics, is that 'the State does not think. ${ }^{15}$ By this he means that the state seldom has a philosophy; instead it has a pragmatic system through which it enacts the necessary performatives which make it a state. I will examine this more closely when examining the behaviour of various actants of the Irish state in the early years of the twentieth and twenty-first centuries. So while the state does not think, in this chapter, I shall think about the state. And, in thinking about states, it is fair to agree with Jacques Derrida who talks about:

binding philosophy to the public 'cause', to the respublica, to 'public-ness', once again to the light of day, once again to the 'lights' of the Enlightenment (aux Lumierres), once again to the en-lightened virtue of public space. ${ }^{16}$

It is this sense of a republic as a concept in the public imagination that is at the core of my investigation. And in parallel to the Trinitarian credo of the French revolution, I would posit three other terms which will steer this discussion, namely 'republic', 'democracy' and 'responsibility'. If the critical space we are creating is to have any valence in the space of the real world, it is important that we have guiding points, and these will provide that intellectual stability. I would begin with the 'republic'.

The idea of the republic is one which is central to much Western political and philosophical thinking. For the Romans, the res publica, literally 'the People's matter', was placed in opposition to res privata. However, the Greek equivalent of 'respublica was not to demosion (the sphere of the Demos, the People's or public sphere), but ta pragmata, literally "things" or "deeds". ${ }^{17}$ This is interesting as it makes the point that a republic can

I5 Badiou, Metapolitics, 87 .

I6 Jacques Derrida and Gil Anidjar, Acts of Religion (London: Routledge, 2002), 47.

I7 P. Cartledge, 'Greek Political Thought: The Historical Context', The Cambridge History of Greek and Roman Political Thought, ed. C. Rowe, M. Schofield, S. Harrison and M. Lane (Cambridge: Cambridge University Press, 2000), I3. 
be very different things in very different contexts. Derrida probes the associated etymology of the second key term, 'democracy', noting that it comes from a fusion of 'a force (kratos), a force in the form of a sovereign authority (sovereign, that is, kurios or kuros, having the power to decide, to be decisive, to prevail, to have reason over or win out over [avoir raison de] and to give the force of law), and thus the power and ipseity of the people (demos). ${ }^{18}$ The notion of the people as sovereign is at the core of both the ideas of the republic and also of the notion of democracy. For Derrida, the fusion of the two guiding concepts:

and the syntax that relates them, the people and power, demos and kratos- or kratein (which also means 'to prevail', 'to bring off', 'to be the strongest', 'to govern', 'to have the force of law') [...] it is on the basis of freedom that we will have conceived the concept of democracy. ${ }^{19}$

The third term, namely 'responsibility', is the most problematic as it is the hinge, or brisure, ${ }^{20}$ around which the other terms turn. The use of the kratos, of power or force, is ultimately sanctioned in the public sphere, the res publica, by the demos, but how that process of sanction takes place is imbricated with the sense of responsibility. It is responsibility that will decide just how the sovereignty of the people will be enacted in the sociocultural sphere.

In The Gift of Death, Derrida speaks of the different types of responsibility which make ethical demands on us. He uses the story of Abraham being asked by God to sacrifice his only son, Isaac, and of the struggle between Abraham's responsibility to the call of the transcendent, to the call of his own family, to the call of his future (in the sense of his son carrying on his genes), and of his responsibility to his community. For Derrida, there is no programmatic right or wrong decision here: 'Abraham is at the same time, the most moral and the most immoral, the most responsible

I8 Jacques Derrida, Rogues: Two Essays on Reason, trans. P-A. Brault and M. Naas (Stanford: Stanford University Press, 2005), I4.

19 Derrida, Rogues, 23.

20 Jacques Derrida, Of Grammatology, trans. G. Spivak, corrected edition (Baltimore: Johns Hopkins University Press, 1997), 65. 
and the most irresponsible.21 For Derrida, an ethical decision is one which must make an 'undecidable leap' beyond all prior preparation for that decision..$^{22}$ Abraham can never be sure whether his decision is right or wrong, and yet he must make the decision: he is in that aporia that exists between the force of justice and the force of law:

I am responsible to anyone (that is to say, to any other) only by failing in my responsibility to all the others, to the ethical or political generality. And I can never justify this sacrifice $[. .$.$] What binds me to this one or that one, remains finally unjustifiable. { }^{23}$

In real terms, this means that the force of justice is an ethical, singular and individual one, rooted in a call of an impossible future: 'justice remains to come, it remains by coming. ${ }^{24}$ Each individual case is an event not governed by the past applications of the rules of law but by a present and future interpretation based on singularity.

I think that such a theoretical critique, if applied to the Irish situation, will cast new light on aspects of that situation. As Derrida points out, in writing about one particular cause rather than another, in pursuing one profession over another, in spending time with one's family rather than at work, one inevitably ignores the 'other others, ${ }^{25}$ and this is a condition of any and every existence. He argues that: 'I cannot respond to the call, the request, the obligation, or even the love of another, without sacrificing the other other, the other others. ${ }^{26}$ Derrida hence implies that responsibility to any particular individual is only possible by being irresponsible to the 'other others', that is, to the other people and possibilities that haunt any and every existence. Responsibility to the one can often result in irresponsibility towards the other, and very often the ethical decision is not as easy as it might sound, and recent events in Ireland have borne this out. An even

Jacques Derrida, The Gift of Death \& Literature in Secret, trans. D. Wills (Chicago: University of Chicago Press, 2008), 72.

22 Derrida, The Gift of Death, 47.

23 Derrida, The Gift of Death, 70.

24 Derrida, Acts of Religion, 256.

25 Derrida, The Gift of Death, 69.

26 Derrida, The Gift of Death, 68. 
more recent crisis in the Irish republic bears this out, and again, it centres on an issue of capital, but in this case, it is financial capital.

The Celtic Tiger, a period in Ireland stemming from the early 1990 , saw a coalescence of cheap credit, a property bubble, and a largely unregulated financial sector - all combining to create a booming Irish economy. However, the cycle of lending to speculate on ever-increasingly priced property eventually came to a juddering halt, and the dealings of a nexus of developers, politicians and bankers has resulted in the financial bankruptcy of Ireland. The banking guarantee of 29 September 2008, which guaranteed the debts of all Irish banks, has resulted in the transfer of the debts of private banks, developers, secured and unsecured bondholders onto the Irish people. This socialization of private debt is, I would contend, the antithesis of capitalism, whose mode of operation would seem to be predicated on venture capital being 'ventured' or risked, in order to make a profit, with the concomitant aspect of this risk being that the money may be lost. Ironically, capitalism was put in abeyance by the troika of the European Commission, European Central Bank and International Monetary Fund when they gave Ireland bailout funding of some $€ 85$ billion.

However, beyond these financial issues, I would like to draw attention to what can only be termed a democratic deficit that was the core of the government's actions in the current situation. I think this deficit needs to be highlighted as it can be seen as a causal factor in our present difficulties, both at a fiscal and a theoretical level. The bank guarantee was concocted by a group of men (I have not heard of any women being present, and this is some five years later), late on the night of 29 September 2008 , and was presented to the cabinet by phone call in the small hours of the morning as more or less a fait accompli. Two of these men were elected, but the rest were not, and we are still not clear on exactly who was involved in those late-night discussions which placed responsibility on the Irish people. There was little cabinet discussion, as the guarantee had been given by the time the cabinet were incorporeally informed. Mary Hanafin, a cabinet minister made this very point in a broadcast on the bank guarantee when she noted that 'That decision should not have been taken at twenty to two 
in the morning on the phone, ${ }^{, 27}$ while her colleague Willie O'Dea agreed that being called on the phone at that hour meant that he 'wasn't in any position to argue', and that he 'didn't have anyone really to argue with. ${ }^{28}$

The excuse was that this information had suddenly come to the fore and that a financial crash would ensue if this guarantee were not given. Leaving aside the sheer incompetence at best, and deceit at worst, that led to a shotgun being placed at the nation's financial head that night, the fact that this decision was made without ever being put before the democratic scrutiny of parliament is a disgrace, and very much counter to any principles that would be expected in a nation that calls itself a republic. What is even more interesting is that a series of meetings on this very topic were held in government buildings in the lead up to this $€ 400$ billion guarantee. The Irish economist Morgan Kelly has made the point that while the IMF wanted bondholders to take their share of the losses to the tune of $€_{30}$ billion, the US treasury secretary Timothy Geithner vetoed this and the debt was lodged with the Irish taxpayer - a decision which the Irish government have never contested nor queried. ${ }^{29}$

At these meetings, it was decided to mortgage the future of Ireland by giving a guarantee of all debts to the amount of $€ 400$ billion (later raised to $€ 485$ billion, which amounted to is per cent of Ireland's Gross Domestic Product). What is most interesting is that only after this group had made their decision was there set out an incorporeal meeting of the cabinet which was effectively asked to rubber-stamp the decision without the opportunity for debate and discussion. In reality this means that ministers were phoned in their homes and told of the fait accompli that had been decided. Worse was to come: despite chief executive of AngloIrish Bank, David Drumm, saying that Anglo-Irish Bank was 'performing strongly' and that profits were 'robust', on 18 December 2008 , the former

27 Mary Hanafin in 'Crisis Inside the Cowen Government', broadcast on 7 November 2011.

28 Willie O'Dea in 'Crisis Inside the Cowen Government', broadcast on 7 November 2011.

29 Morgan Kelly, 'Ireland's Future Depends on Breaking Free from Bailout', Irish Times, 7 May 20 I. 
CEO of the bank, Sean Fitzpatrick, resigned after shareholders found out about his $€ 87 \mathrm{~m}$ hidden loans. Three days later, the government announced a $€$ I.5 billion bailout for Anglo-Irish Bank.

The net result of all this was that the economy collapsed. Unemployment rose from 4 per cent in 2006 to 14 per cent by 2010 , while the budget went from a surplus in 2007 to a deficit of 32 per cent GDP in 2010, the highest in the history of the Eurozone. In 2011 the deficit was 13 per cent; in 2012 it was 7.6 per cent and in 2013 it was 8 per cent. Austerity has been ushered into Irish society through these actions, and those of the property bubble that preceded them. Of course, this is not just an Irish phenomenon; Greece, Portugal and more lately Spain, Italy and Cyprus are also part of this process of bailout and austerity. So what has this to do with the topic of this chapter, which is to examine the French influence on the mindset of the Irish republic? The work of another intellectual whose work has been seminally influenced by French theory, namely Slavoj Žižek, is a good starting point because, through his work, that discussion space of which Badiou has spoken can be addressed.

Speaking of the current financial crisis, Žižek notes that the austerity can be narrativized in two different ways. The first is the predominant, establishment story which proposes a de-politicised naturalisation of the crisis: the regulatory measures are presented not as decisions grounded in political choices, but as the imperatives of a neutral financial logic - if we want our economies to stabilise, we simply have to swallow the bitter pill'. The other story, which is told by workers, students and pensioners, would see the austerity measures as 'yet another attempt by international financial capital to dismantle the last remainders of the welfare state. ${ }^{30}$ In the Irish case, the troika is similarly double-edged in perspective: it is a technocratic device that saved the Irish from their profligate spending habits (Enda Kenny's comment at the Davos conference, 'people went mad with borrowing' is just one example; others would be that 'we all partied'; 'we lost the run of ourselves' and the classic sonorous tautology: 'we are where

30 Slavoj Žižek, 'A Permanent Economic Emergency', New Left Review 64 (July/August 2010), 85 . 
we are'); or else it is an agent of oppression that condemns this country to paying $€ 3.5$ billion each year to service the bondholders of Anglo-Irish Bank, a bank which no longer exists. For Žižek, there is a superego dimension to the way the IMF (and by extension the ECB and the European Commission) treats its clients, as 'while scolding and punishing them for unpaid debts, it simultaneously offers them new loans, which everyone knows they will not be able to return, thus drawing them deeper into the vicious cycle of debt generating more debt. ${ }^{31}$ The choices facing Ireland, such as the ratification of the European Fiscal Compact treaty of 2012, or whether to accept the bailout, or whether to recapitalize the banks, were all choices of the symbolic order and not real choices. The real choice was made by that cabal of people who were coerced into the decision that the taxpayer should be responsible for the debts of the banks. That choice was, in every sense of the term, a real choice, and the choices that we are now offered are very much not real.

The choices were what Lacan terms the forced choice. Lacan formulated this choice as the alternative to le perre ou pire, 'the Father or worse', where the choice is 'not between good and bad but between bad and worse. The forced choice of community, i.e. the subordination to the authority of the Name of the Father, is "bad"' ${ }^{2}$ Lacan gave a very apt example to explain the restricted nature of this choice by saying it was best embodied in the phrase: Your money or your life! If I choose the money, I lose both. If I choose life, I have life without the money, namely, a life deprived of something. ${ }^{33}$

The Stability Treaty, on which the Irish people voted on 3I May 2012, was very much le perre au pire, since citizens were not being asked to choose whether it was responsible to take private debt from banks and bondholders and socialize this debt, so that ordinary citizens now pay such debt. A classic example is that of the $€ 4.5$ billion given to Greece by the IMF and

3I Žižek, 'A Permanent Economic Emergency', 85.

32 Slavoj Žižek, Enjoy Your Symptom!: Jacques Lacan in Hollywood and Out (London: Routledge, 2007), 75 .

33 Jacques Lacan, The Four Fundamental Concepts of Psycho-Analysis, trans. A. Sheridan (London: Hogarth Press, 1977), 212. 
ECB in May 2012 - of which nearly 4 billion went straight back to the European Central Bank - the difference now being that the money had become a payment of sovereign debt. The same happened in Ireland, as some $€ 6 \circ$ billion of the Irish bailout went to reinforce the banks, which is code for paying their debts and for de facto making those debts Irish sovereign responsibility. In a Derridean sense, Ireland is now responsible for the gambling of bondholders - the Irish are 'the other other'.

Derrida sees justice as intimately connected with notions of responsibility to the 'absolute singularity of the other, ${ }^{34}$ and to an 'endless promise' to the future. ${ }^{35}$ In Specters of Marx, Derrida spelled out his call for justice: 'not for calculable and distributive justice [...] but for justice as incalculability of the gift and singularity of the an-economic ex-position to others. ${ }^{36}$ I would argue that such a view of justice as central to political, national and economic interaction represents the radical potential for dissident thought within the debt debate. I would also point to the term 'an-economic' as being especially relevant to our current situation, as our version of democracy seems to be umbilically connected to the model of the markets and to the business mentalité. On being asked about the role of deconstruction within the political, Derrida says that the life of any institution implies that 'we are able to criticize, to transform, to open the institution to its own future. ${ }^{37}$ In real terms, this means that the force of justice is an ethical, singular and individual one, rooted in a call of an impossible future: 'justice remains to come, it remains by coming. ${ }^{38}$

34 Jacques Derrida, 'On Responsibility'. Interview with Jonathan Dronsfield, Nick Midgley and Adrian Wilding', Responsibilities of Deconstruction: Warwick Journal of Philosophy, 6 (Summer 1997), 25.

35 Jacques Derrida and Derek Attridge, Acts of Literature (London: Routledge, 1992), 38 .

36 Jacques Derrida, Specters of Marx: The State of the Debt, the Work of Mourning, and the New International, trans. P. Kamuf (London: Routledge, 1994), 22-3.

37 Jacques Derrida and John D. Caputo, Deconstruction in a Nutshell: A Conversation with Jacques Derrida (New York: Fordham University Press, 1997), 6.

Derrida, Acts of Religion, 256. 
As Derrida puts it, the 'messianic' attitude is one which constitutes 'the historical opening to the future. ${ }^{39}$ For him there is an intrinsic connection between the messianic and democracy-to-come, since the messianic 'obliges us to think, from there, another space for democracy. For democracy-tocome and thus for justice. ${ }^{40}$ I would relate Derrida's ideas on democracyto-come with Badiou's concept of democracy as an Idea (using the capital I) which he equates with the Lacanian Real. Both thinkers wish to keep the familiar term but also to flag the problematic associations which it has, and which Badiou terms its 'prostitution by capitalo-parliamentarism. ${ }^{41}$ For Badiou, one way to do this is through what he calls a 'new present', and he exemplifies this in a discussion of the movement of the army of Spartacus during the slave rebellion of $73-7 \mathrm{I} \mathrm{BCE}$. He makes the point that, in revolting, slaves were changing the very nature of what being a slave meant in that present series of actions; these actions were the 'realisation in the present of a hitherto unknown possibility. ${ }^{\prime 2}$ I would see this as the value of French theory in redefining the mentalité of the Irish public imagination, and indeed of what it means to be a republic in the contemporary world This perspective will allow for a necessary critique and resultant redefinition of what the concept of a republic means in contemporary Ireland.

This sense of an orientation towards a more just form of democracy may seem unduly idealistic and utopian in the real worlds, but surely the discursive political space that is philosophical and theoretical thinking must look to alternative paradigms, as well as to critiquing the existing hegemonic symbolic order. The idea of a new present, open to the future and to alternative notions of naming is precisely what Badiou traces in the Spartacan rebellion:

39 Derrida, Specters of Marx, 167.

40 Derrida, Specters of Marx, 169.

4I Alain Badiou, The Meaning of Sarkozy, trans. D. Fernbach (London: Verso, 2008), 9I.

42 Alain Badiou, Logics of Worlds: Being and Event, 2 (London: Continuum, 2009), SI. 
First of all, the slaves 'as a body' (as an army) move in a new present; for they are no longer slaves. Thus they show (to the other slaves) that it is possible, for a slave, no longer to be a slave, and to do so in the present. ${ }^{43}$

The new present is influenced by the past and by events from the past; however it also influences the future. As Ed Pluth observes, even though the strength of the rebellion was 'denied and occulted' at the time, 'it provides a kind of stuff that can always be made relevant again to future situations and worlds. ${ }^{34}$ The new present and the messianic allow us to look afresh at events of the past and at how they have shaped the present. When Ireland first lost its economic sovereignty, there was much discussion about the values of the men and women of 1916 , and of how the current situation is anathema to those values. There has also been a call to reinvent the republic, or to set out a second republic, in the light of current events. Issues of sovereignty and shame have been raised. An appeal to the past can be instructive, but such an appeal needs to be clear-headed and aware of the tendency to narrate the past in an over-positive light. So if an attempt is made to look for the real of aspects of the past, comparisons arise which, while they may shake preconceptions, may also pave the way towards a new, messianic sense of the now.

Thus, on 24 April 1916, a small select group, with no mandate from anyone, not even their own organization, the Irish Volunteers, took a sudden decision which resulted in the destruction of the centre of Dublin and which caused thousands of casualties. These people took their mandate from a personified past of the 'dead generations.' They declared a republic but left very little account of the nature of such a republic or of the ideology or philosophy which underpinned their revolution. They came close to occupying Dublin Castle but had no plan beyond this, and while occupying the General Post Office, they did not occupy the telephone exchange. Events moved out of their control after their surrender, and eventually, given the lack of any radical agenda for change, the country ended up taking on all the trappings of the colonial power which they had rejected, and with the

43 Badiou, Logics of Worlds, 5 I.

44 Ed Pluth, Badiou: A Philosophy of the New (Cambridge: Polity Press, 2010), I47-8. 
Free State government using British weapons to shell the 'irregular forces' at the beginning of the Irish Civil War on 28-30 June 1922.

On 28 September 2008 , a small group of men took a decision on nationalizing private banks, one which has also caused destruction and chaos. Two of these were second-generation politicians whose main claim to fame was in their ministerial positions, and whose route to power may well have owed much to the fact that their fathers had been politicians. The bankers and advisers were also members of a small class-based elite. Again, there was no real plan or philosophy underpinning this plan and, as can now be seen, events have moved out of their control, and some of the 'gallant foreign allies' referred to in the Proclamation of the 1916 Rising, meaning Germany which was at war with Britain at the time, still have an office in Dublin, having effectively governed Ireland financially from 2008 to 2013 , and will hold the de facto economic fate of Ireland in their hands for the foreseeable future. In both cases, wearing the green jersey was seen as an end in itself whereas, in fact, a jersey is merely a garment that is worn when one is actually doing something; it is not an end in itself.

So, if appeal is made to the past, let it be an honest look that includes the mistakes of the past. In terms of democratic deficit, lack of strategic planning, and no sense of responsibility to the demos, both groups share strong similarities. Of course the dual perspective remains of two groups of Irishmen who wore the green jersey and did their best according to the information they had. A second republic is really looking too far ahead; it would be a better idea to question how one might actually form, define and structure a republic of Ireland that is of the people, for the people and by the people, a people defined under the common name of Irish men and women, regardless of religion. That point was raised by Fintan O'Toole in a recent book, but it has not really entered a broader debate. When looking at the Irish bank bailout, by all means look too at the credit boom and the property bubble, but let it also be remembered that by far the largest proportion of Irish debts 'have been run up as a result of massive financial sector bailouts, as well as by falling government revenues during the 
recession. ${ }^{45}$ It should also be remembered that, as Žižek notes: 'the big loan to Athens will be used to repay Greek debt to the great French and German banks. ${ }^{36}$ For thinkers such as Derrida, Badiou and Žižek, it is the current manifestation of liberal democracy which is at the core of the problems people may go hungry because they over-borrowed but banks cannot fail because they over-extended their credit. The symbolic order of capitalism is precisely that politics is at the service of business: Marx's once-scandalous thesis that governments are simple business agents for international capital is today an obvious fact on which 'liberals' and 'socialists' agree. ${ }^{47}$

This is something that must be addressed in the Irish public imagination. The real of our new present must be acknowledged, namely that 'electoral democracy is only representative in so far as it is first of all the consensual representation of capitalism, or of what today has been renamed the "market economy". ${ }^{48}$ Defining the democratic real is an important task:

As long as we are persuaded, like the Thermidorians and their liberal descendants, that it resides in the free play of interests of particular groups or individuals, we shall see it deteriorate, slowly or rapidly according to circumstances, into a hopeless corruption. Genuine democracy, which is what I believe we have to preserve, is a quite different concept. ${ }^{49}$

So, in terms of using the space of philosophy as an originary point for some form of reimagining the new present in a messianic way, what would be the implications? I shall sketch out some of these. Firstly, by looking for the Lacanian real in the symbolic order, and for taking responsibility for the demos and for the res publica, I would suggest that for all public figures, a deal of financial transparency is necessary. We now have ministers whose financial dealings have to be declared, but already, there have been lacunae

Fintan O'Toole, Enough is Enough: How to Build a New Republic (London: Faber, 20II); Fintan O'Toole, ed. Up the Republic: Towards a New Ireland (London: Faber, 2012).

46 Žižek, 'A Permanent Economic Emergency', 85-6.

47 Rancière, Disagreement: Politics and Philosophy, II3.

48 Badiou, The Meaning of Sarkozy, 91.

49 Badiou, The Meaning of Sarkozy, 91. 
in these declarations. A simple law, decreeing that any minister, politician or public servant who has accumulated finances for which they cannot account, should have their parliamentary privileges suspended forthwith, and until they could account for such funds, and that such suspension should in no way prejudice, nor preclude, criminal investigation. Here, the responsibility would be shown to the demos, and the kratos would be significantly foregrounded, and it would make for a sense that with reward comes accountability.

In terms of the financial crisis, all bankers who were involved in the bank bailout should be subject to criminal charges. On the night of 29 September 2008, they denied that the crisis was one of solvency, stressing that instead, their problem was liquidity. If they knew differently on that night, then that is fraud and there are laws that can be invoked and implemented; if they did not know, that is gross incompetence, and there are procedures that can be invoked to deal with that. If fraud is proven, there should be criminal sanctions; if incompetence is proven, there can be financial sanctions.

In terms of the socialization of banking debt, this should be taken to the European Court of Human Rights, as it is a gross injustice. This may seem utopian, and I can almost hear the cries that someone has to pay off the debt but this is again, le pere au pire - the forced choice that, while rooted in the symbolic order, is not part of the real. On Monday 2r May 2012 , some $€_{4}$ trillion was wiped off the markets due to worries about the Greek exit from the EU, about the burgeoning problems with Spanish banks, and the general fear of contagion. I want to repeat that number $-€_{4}$ trillion. Where did it go? Is there a room where European public servants are busily burning this money and then printing more when the markets increase in value? This money is symbolic, and the same is true of much of the bank debt that is being paid to secured and unsecured bondholders.

Looking at the present event, we could argue that private debt is private and not public - there would be strong support from a number of other countries on this, and again, an appeal to the European Court of Human Rights could well prove that such bank bailouts are illegal. We can also invoke the symbolic order of capitalism. The very term signifies risk or venture capital, money which is risked in order to attain profit. The 
obverse of this is that a loss can occur (a point made in the small print of every advertisement for financial services: 'the value of investments can fall as well as rise'). The very nature of the capitalist experience, namely that of risking money to earn more money, is something that has been occluded in the symbolic order of this crisis, and it is a point that needs to be made again and again if it is to attain any purchase in the public imagination.

One of the key problematics of this crisis has been the financial elite's fear of letting a bank fail. Indeed, rumour has it that US treasury secretary Timothy Geithner's insistence that the bondholders should not suffer any losses, was one of the main reasons why Anglo-Irish Bank is still getting money from the Irish taxpayer, even though it is now a failed entity. So the question arises, if this money is really part of a symbolic order which has no contact with the real - and I have already adverted to what could be termed a very fancy money-laundering project to change private debt into public debt - then why is Ireland suffering real consequences without ever questioning this? Why are the Irish paying the debts of people who are not even Irish? And why are banks still in operation after such catastrophic errors? Economist Morgan Kelly, one of the very few people who predicted the bursting of Ireland's property bubble, has provided an acute analysis of the situation: the IMF 'which believes that lenders should pay for their stupidity before it has to reach into its pocket, presented the Irish with a plan to haircut $€ 30$ billion of unguaranteed bonds by two-thirds on average'. However, this 'haircut' was vetoed by 'US treasury secretary Timothy Geithner who, as his payment of $\$ 13$ billion from governmentowned AIG to Goldman Sachs showed, believes that bankers take priority over taxpayers. ${ }^{50}$

There is little doubt that, buoyed up by the infusion of funds from the Irish taxpayer, these banking institutions will eventually come back into profit. It is fascinating that no-one has mentioned a levy on future profits which would remain active until all bailout funds are repaid to the public purse. There has been an eloquent silence on this issue and, as far

so Morgan Kelly, 'Ireland's Future Depends on Breaking Free from Bailout', Irish Times 7 May 20 II. 
as I know, it has never been mooted. One can almost hear the complaints about the markets not being able to function with such a levy, to which the answer must be - the markets could happily be put in abeyance in order that no bank could fail, so the same logic should apply to paying back their debts to the public, to the socius, to us. Here we see that sense of transitive responsibility of which Derrida has spoken, with the godlike voice being that of Geithner, and the Irish taxpayers taking on the role of the sacrificial Isaac. Once more, the identification was with the kratos as opposed to the demos; it was with the symbolic order, wherein the diplomat and ministers have their being, as opposed to the real of people suffering cutbacks, unemployment. Cultural critique provides the intellectual tools with which to argue these points, and to set out an oppositional framework that cannot be dismissed as being Luddite, or anti-European, because:

utopian as it may appear, the space is still open for another Europe: a re-politicized Europe, founded on a shared emancipatory project; the Europe that gave birth to ancient Greek democracy, to the French and October Revolutions [...]. More than ever, the reply to every crisis should be more internationalist and Universalist than the universality of global capital. ${ }^{51}$ 



\section{'So much depends on a TV appearance': Popular and Performative Aspects of the Poetry of Brendan Kennelly}

\section{Introduction}

The popularity and visibility of Brendan Kennelly as a readily recognizable Irish poet can be viewed in both a positive and a negative light. On the one hand, many people applaud his anti-elitism and populist approach to poetry and his ability to communicate with an audience at readings and in academic lectures. His capacity as a communicator famously extends to the mass media, including TV, and a recent newspaper review of The Essential Brendan Kennelly (20II) notes that:

people approach him because they have the illusion of knowing him, even if that illusory knowledge has been largely based on his many Late Late Show appearances down the years, where he came across as a cuddly Celtic sage, and on the endearingly daft television ads he did for Toyota - daft because he didn't drive and endearing ... well, because he was Brendan. ${ }^{1}$

As a poet, he enjoys a 'recognition factor' higher than most even if that recognition is not exclusively based on a reading of his poems.

I 'Review: The Essential Brendan Kennelly', unsigned, The Irish Independent, < http:// www.independent.ie/entertainment/books/review-the-essential-brendan-kennellyed-by-terence-brown-and-michael-longley-with-cd-of-poems-read-by-author-2621235. html>. Accessed 2 July 2012. 
The negative side of Kennelly's visibility has been well-rehearsed by critics and commentators. The central charge is that he is too prolific, that he lacks an ability to edit himself and therefore allows casual or under-developed poems to be published. The assumption here is that his popularity is a personal one which is not merited by the formal accomplishments of his published poetry. The implication of the recent selection The Essential Brendan Kennelly, edited by Terence Brown and Michael Longley (2011), is that Kennelly's work needs editing. Indeed, Brown and Longley are aware of this censure and seek to defuse the issue in their Foreword where they point out that: 'For some, such abundance and availability seemed the point where the prolific risked becoming profligate, as talent can disperse itself in mere productivity and performance." Lucy Collins, in her contribution to The Cambridge Companion to Contemporary Irish Poetry titled 'Performance and dissent: Irish poets in the public sphere' also acknowledges this problem when she notes that 'The enduring popularity of Brendan Kennelly's poetry is perhaps its most striking feature ${ }^{33}$ as if popularity is a goal in its own right. She goes on to examine Kennelly's contribution to the 'public sphere' in terms of Kennelly's popularization of the epic form and his highprofile poetic intervention into Irish social debates.

The purpose of this essay is not to defend Kennelly against charges of over-production or to make any extravagant claims for his importance within the totality of Irish poetry since Yeats. Rather, I wish to explore how the idea of 'the popular' and the anti-elitist is part of the Kennelly persona and poetic identity. Further, since Kennelly is a renowned public speaker and reader of his own poetry, this essay will also explore the performative aspects of the Kennelly canon both in terms of Kennelly's own projection of his poetry (and of himself) and the ways in which Kennelly's conception of poetry as a time and space for different voices to be heard (often dissonant or marginalized voices) is fundamentally performative. A consideration of

Terence Brown and Michael Longley, 'Foreword', The Essential Brendan Kennelly (Tarset: Bloodaxe, 20II), iо.

3 Lucy Collins, 'Performance and dissent: Irish poets in the public sphere', The Cambridge Companion to Irish Poetry, ed. Matthew Campbell (Cambridge: Cambridge UP, 2003), 212. 
this kind may reveal important truths about the relationship of modern Irish poets to their audience and the extent to which poetry still inhabits the public imagination at the beginning of the twenty-first century.

\section{Popularity and the poet's persona}

Poetry is most often considered the least popular of literary genres and the idea of a popular poet can rouse suspicion suggesting, as it does, the deliberate courting of an audience or the simplification of an intrinsically complex art. These are perhaps prejudices inherited from a modernist paradigm in which poetics were seen as necessarily 'difficult'. Nonetheless, poetry nowadays is primarily the preserve of the academy and subject to an intensive academic scrutiny so that the old-fashioned gulf between 'the intellectual' and 'the common reader' still exists in respect to poetry.

It is interesting, therefore, to remind ourselves of an essay written at the turn of the last century by W.B. Yeats with the title 'What Is "Popular Poetry"?' published in 1902. In this essay, W.B. Yeats weighs up Irish poetry of the nineteenth century as it impacted upon his development as a nationalist poet:

I think it was a Young Ireland Society that set my mind running on 'popular poetry'. We used to discuss everything that was known to us about Ireland, and especially Irish literature and Irish history. We had no Gaelic, but paid great honour to the Irish poets who wrote in English, and quoted them in our speeches. I could have told you at that time the dates of the birth and death, and quoted the chief poems, of men whose names you have not heard, and perhaps some of whose names I have forgotten. I knew in my heart that most of them wrote badly, and yet such romance clung about them, such a desire for Irish poetry was in all our minds, that I kept on saying, not only to others but to myself, that most of them wrote well, or all but well. ${ }^{4}$

4 W.B. Yeats, 'What is Popular Poetry?', Essays and Introductions (New York: Macmillan, 196I), 3 . 
These are the poets mentioned in Yeats' poem 'To Ireland in the Coming Times' of I 892 who, in the words of that poem, 'sang, to sweeten Ireland's wrong / Ballad and story, rann and song, poets named as Thomas Davis (1814-1845) - leader of the Young Ireland group - James Clarence Mangan (1803-1849) and Samuel Ferguson (1810-1886). These were enabling voices for the Yeats of the 1890 , but as his essay acknowledges, their poetic qualities are uneven.

Yeats identifies three properties of the popular poetry of his day which he admires and, to an extent, sought to emulate in his verse of the 1890 . It must be indigenous - to come from 'the people'. It must be spontaneous or have what Yeats calls a 'gusty energy'. It must also be authentic in the sense of drawing on local conditions - 'climate and scenery' - in order to better assert its genuine provenance from the land. It goes without saying that Yeats possessed none of these seemingly peasant qualities coming from Anglo-Irish stock and being an aloof intellectual, devoted craftsman and cultural mediator in the Revival Movement. Indeed, despite this valorization of 'the popular' by Yeats, his vision of a national poetry irrigated by an indigenous 'folk' tradition is, of course, transparently elitist. The offer of forgiveness for formal clumsiness if the poetry is deemed 'authentic' or 'from the people' is based on nationalist, not aesthetic, considerations, as Yeats makes clear.

The poet who would meet the criteria which Yeats set out was Patrick Kavanagh and I want to suggest that it is by means of the antithetical influence of Kavanagh and Yeats that we may begin to discuss Kennelly's poetry and its relationship with an Irish audience. In his essay on 'Patrick Kavanagh's Comic Vision', Kennelly makes some important claims which reveal his own sense of poetic inheritance:

There are certain poets of whom it can be said that they have a unique personal vision - Blake and Yeats for example - and one knows immediately what is meant. They have a new, inimitable, disturbing way of looking at life and, at their best, they communicate this vision successfully. In twentieth-century Ireland, one poet (apart from Yeats) possesses such a vision - Patrick Kavanagh [...] It is with Blake and Yeats 
that Kavanagh must be compared, for he is a visionary poet and towards the end of his life he claimed that he had achieved a truly comic vision. ${ }^{5}$

Kennelly's essay traces Kavanagh's career as a movement towards a comic vision which is less about laughter and more about reconciliation and redemption, the sentiments famously embraced in the Canal Bank sonnets. However, it is worth dwelling here on the role played by Kavanagh and Yeats in what I take to be Kennelly's own ultimately 'comic vision'. The spontaneity and authenticity of many lyric poems written by Kennelly share in the clearly-stated local and rural outlook which Kavanagh adopted in his early poetry - and mirror the indigenous qualities mentioned by Yeats. Equally, Kennelly's poetry (unlike Kavanagh's) is a poetry of voices and personae and here perhaps we see the influence of Yeats whose poetry is often a matter of masks and actors voicing a perspective. Kennelly's acknowledgement of the 'unique personal vision' of both these poets is perhaps a way of reckoning with the two poets' demonstrable influence on Kennelly's own work. From Kavanagh, Kennelly takes his rural themes, his insouciance, his authenticity; from Yeats, he takes his gravitas, his sense of history and his ventriloquism.

In as far as these three writers - Yeats, Kavanagh and Kennelly - may be said to have left their mark on the public imagination, it is not only their poetry which can be considered a decisive factor in their influence. All three may be said to have conducted what Kennelly calls, in an essay on W.B. Yeats: 'An Experiment in Living.' ${ }^{6}$ As Kennelly suggests, in the case of Yeats, this 'experiment' was both public and private and is reflected in work which is both 'personal and impersonal" and which represents both man and masks. To a substantial degree, Kennelly's experiment echoes that of Yeats' to the extent also that Kennelly's oeuvre includes examples of lyrical self-revelation combined with extended sequences of impersonal 'voicings' of invented poetic personae (Cromwell, Buffún, Judas, Ace de ed. Åke Persson (Tarset: Bloodaxe, 1994), ro9.

6 Brendan Kennelly, 'W.B. Yeats: An Experiment in Living', Journey to Joy, 23I-47.

7 Kennelly, Journey to Joy, 247. 
Horner). Kennelly often allows his lyric voice to act as a lightning rod for the voices of others just as Yeats invented so many poetic personae to enact his personal dramas. There is nothing hermetic here; the poetry is performative, complex and multi-valent. But whether the poet uses a personal lyrical voice or an impersonal performative voice, he still inevitably engages in the presentation of his authorial persona at work behind the poems, a persona which is intended to be part of the public domain.

Kennelly's use of Prefaces to introduce his work is part of this authorial presentation and orchestration; indeed, Kennelly is unusually forthcoming in revealing his poetic procedures. Most often, he explains his role as one of mediator to the voices his poetry articulates. Kennelly's explications place him in a bardic relationship to his material in as far as he disavows authorial agency or 'inspiration' beyond a passive openness to the voices of the poem as they emerge in his consciousness. In his best-known poems, Kennelly articulates the voices of others, either people he has known, or fictional personae, or even inanimate objects. Kennelly is not, therefore, a lyric actor in his poems; for the most part he operates as a bardic puppetmaster, controlling the performance from an off-stage position. However, this in itself is one kind of self-cast, invented rôle, cultivated by Kennelly, who has, in the eyes of Christopher Murray: 'invented his literary persona [...] derived from a clearly worked out concept of the poet as story-teller.' The literary persona exists mainly outside or behind the poem. But it nonetheless exerts a force on the poem in terms of subject matter, form, style and tone. As Murray remarks: 'If it is a "time for voices" it must be a time for the Kennelly "voices".' The supposed openness of the poet to 'the voices' which in habit him, in all their diversity, in fact issues in a certain thematic conservatism by which we can recognize the Kennelly poem and persona. This is why, across many collections, there is a fundamental tonal similarity in Kennelly's work: jocular, off-beat, mocking, comical, absurdist, casual, sharply observant but rarely earnest or troubled. We might Brendan Kennelly, Studies: An Irish Quarterly Review 79.316 (Winter 1990): 435-6. 
attribute this consistency to Kennelly's rural upbringing, and in particular to the performative customs of rural Co Kerry which has maintained its inherited Irish tradition of song and recitation. It is the latter practices that are celebrated by Kennelly in his poetry. As Christopher Murray suggests:

He learned early to perform. He learned also to appreciate the style of the traditional story-teller and verse-maker, whose art stems from folk tradition, is communal in form, simple in diction and as strong in the celebration of natural instinct as in mockery of self-regard, injustice or hypocrisy. ${ }^{10}$

Many of Kennelly's poems offer robust rural insights, sometimes based on earthy humour, sometimes characterized by injustice and often celebrating eccentrics and local people from Kennelly's Kerry experience (the poems of Love Cry - 1972 - are exemplary in this respect). We should be cautious in attributing a thematic or tonal multiplicity to Kennelly's poetry because it is, most often, the Kennelly voice which we hear, even when it is ventriloquized dramatically as the voice of an-other. That voice is part of a literary persona which has had a strong impact on the Irish public imagination in the form of the Brendan we all think we know; but it is, I suggest, a singular, rather than protean or multiple persona. Although often presented in the plural as 'voices' - or A Time for Voices as Kennelly's 1990 Selected Poems 1960-2004 is entitled - not as a singular voice, we nonetheless learn to recognize the unique 'Kennelly voice'.

I think we should insist on this singularity in spite of the fact that Brendan Kennelly in his life, as well as in his poetry, has been a man who has played many roles: university professor, poet, anthologist, media personality, man about town. He is a near-equivalent, in Irish terms, to the public intellectual as conceived in France and more generally in Continental Europe. An Irish Times article, published on the occasion of Kennelly's seventy-fifth birthday in April 20 II, referred to him as the 'people's poet."

II 'People's poet at 75', unsigned, The Irish Times (I6 April 20II). < http://www.irishtimes. $\mathrm{com} /$ newspaper/opinion/2011/0416/1224294798143.html>. Accessed 22 October 2011. 
Fred Johnston, reviewing Kennelly's selected poems A Time for Voices (1990) in the Irish University Review, made the distinction between 'populist poets, whom the media may cultivate, and the others (symbolized, say, by Heaney) who are the property of academic criticism and the $T L S .{ }^{12}$ Kennelly himself might well resist this distinction of popular and elite Irish poetries, but as a matter of public perception, it seems justified.

Here, I am trying to outline what Richard Pine refers to as 'the tension between public and private personae, between poet and orator. ${ }^{13}$ As already mentioned, an image of Kennelly exists in the public imagination chiefly due to his media appearances and high profile poetry readings so that people think they 'know' Brendan Kennelly even if they are not well-acquainted with his poetry. Indeed, the tribute book edited by Åke Persson titled This Fellow with the Fabulous Smile (1996) even included sets of interviews from Dublin and Tralee in which the book's editor asked passers-by if they had heard of Brendan Kennelly and what they thought of him. Behind this half-serious exercise in field-research lies the media construction of the affable Brendan who will 'give the time of day' to whomever he happens to meet. It seems that Kennelly is comfortable with his persona as poet of the people and indeed, to some extent, feeds off it: he called his largest single collection Familiar Strangers: New and Selected Poems 1960-2004 (2004). In his enjoyment of Dublin slang and other demotic Englishes and in his sauntering, street-walking appreciation of 'streetbites', it would seem that part of Kennelly's projected self is one of ease with chance encounters and happenstance which translates into an avowed philosophical openness to chance and the everyday.

But clearly this is not the whole story. A poet who has produced over twenty books of poetry must, by definition, have a taste for solitude, reflection and work. This is a point insisted upon by Terence Brown and Michael Longley in their Foreword to The Essential Brendan Kennelly (20II) where

I2 Fred Johnston, Review of The Death of Metaphor by Desmond Egan; A Time for Voices: Selected Poems 1960-Iggo by Brendan Kennelly, Irish University Review 22.I (Spring/Summer 1992), 194.

I3 Richard Pine, 'Introduction', Dark Fathers into Light: Brendan Kennelly, ed. Richard Pine (Tarset: Bloodaxe, 1994), 16. 
they state that Kennelly's 'life has, in fact, been intently dedicated to the practice of an art rooted in solitude and privacy. ${ }^{14}$ However, allowing for the poet's necessary solitude, it is still possible to examine ways in which Kennelly's private space has been extensively shared with others, often through the media, and also in the poems themselves. More than most poets (and it is an engaging part of his personality), Brendan Kennelly chooses to share that solitude with us in his work, and to break that solitude through his numerous readings, interviews, and other public appearances. Kennelly's advocates argue that the public persona obscures the creative integrity of Kennelly the poet, an integrity which Brown and Longley's selection aims to foreground, and which they and others view as undervalued. Kennelly's detractors, on this other hand, claim that the Kennelly persona has damaged Kennelly the poet so that his undoubted talent has been dissipated by the energy required just to keep being Brendan.

\section{The poet as social critic}

Rather than choose between these alternatives, it may be possible to advocate a reading of Kennelly's poetry that shifts the emphasis away from his published canon, or at least its formal properties, and towards the totality of his contribution to Irish cultural life. In other words, if one considers the equal contributions of poet and his public persona, perhaps the impact Kennelly continues to have on the Irish public imagination can be better measured. This involves side-stepping Brown and Longley's efforts to define Kennelly's formal achievement and instead concurring with John Redmond's assessment in The Oxford Handbook of Modern Irish Poetry that: 'Although his achievements as a poet are questionable, Kennelly remains a significant literary figure. As his career in education might suggest, he is 
at his best as a teacher, whether at the podium or on a television panel. ${ }^{15}$ By insisting on the thematic virtues of the poems as social statements, alongside Kennelly's public voice as a lecturer and public figure, one may hit upon the key virtues of the Kennelly canon.

The Swedish critic Åke Persson further suggests, in his study Betraying the Age: Social and Artistic Protest in Brendan Kennelly's Work, ${ }^{16}$ that considering Kennelly's poetry as a social intervention of a deliberately public kind may be as important as analysing the poetry's formal strengths and weaknesses. Persson's study takes as its keynote a well-known line from the poem 'Service' from The Book of Judas (1991): 'The best way to serve the age is to betray it. ${ }^{17}$ This line invites a reading of Kennelly's poetry in oppositional terms, especially since he uses historically reviled figures as leading personae in Cromwell (1983) and The Book of Judas (1991); nor do the antics of his other dramatis personae inspire confidence or trust. Neither Ace de Horner, nor Moloney, nor Buffún, nor Tinker nor any of his diverse gallery of misfits is supposed to enact the voice of respectability and authority, except in parody. The opposite is the case and Kennelly in his Prefaces has emphasized his wish to offer a voice to the social outcast or the social misfit. For John McDonagh in his study Brendan Kennelly: A Host of Ghosts - and this is also true of Persson's work - Kennelly's poetics 'exists on the margins, eating away at a monolithic cultural centre. ${ }^{18}$ This viewpoint sees Kennelly's work as an example of 'unstable counter-culturalism ${ }^{\text {'19 }}$ wherein Kennelly's voice - or his 'one-for-all and all-for-one' assembly of voices - is

Is John Redmond, 'Engagements With the Public Sphere in the Poetry of Paul Durcan and Brendan Kennelly', The Oxford Handbook of Modern Irish Poetry, ed. Fran Brearton and Alan Gillis (Oxford: Oxford UP, 2012). <http://www.oxfordhandbooks.com/ view/10.1093/oxfordhb/9780199561247.001.0001/oxfordhb-9780199561247-e-26>. Accessed 19 August 2013.

I6 Åke Perrson, Betraying the Age: Social and Artistic Protest in Brendan Kennelly's Work (Gothenburg: Acta Universitatis Gothoburgensis, 2000).

I7 Brendan Kennelly, 'Service', The Book of Judas (Tarset: Bloodaxe, I991), I7.

I8 John McDonagh, Brendan Kennelly: A Host of Ghosts (Dublin: Liffey Press, 2004), I49.

McDonagh, A Host of Ghosts, I5I. 
directed from the margins to the centre in order to question the received wisdom and prejudices of Irish society and its institutions.

This appears to be the default reading of scholars: it takes Kennelly on his own terms as one who ventriloquizes the voices of the voiceless. However, we need to be careful in how we interpret Kennelly's position in relation to the society he critiques. If we consider Kennelly's place in the Irish public sphere and his status as a Trinity College Dublin professor and regular contributor to social debates in Ireland, it may seem that Kennelly's interventions emanate more from the centre than from the periphery. In his Preface to the 1999 volume Begin, Kennelly refers to 'poetry's shocking democracy ${ }^{20}$ which allows the victims and vanquished to have their say. It remains the case, however, that it is only the status of Brendan Kennelly as a respected Irish poet which actually enables this or that voice to be heard. We may applaud Kennelly's natural dislike of elitism, his creative openness to others and to ordinary experience, and still recognize that it is through the singular agency of Kennelly himself that this democratic vista opens up. The voices are still the 'Kennelly voices' and he remains, arguably, in life as in literature, the agent and author-ity behind these voices.

Therefore, even though it is against the spirit of Kennelly's poetic vision as expressed in his many Prefaces, I prefer to see him as a unique poet and cultural commentator whose singular voice is 'in tune' with the Irish public. Perhaps Kennelly is an 'alternative voice' when compared to the voices of clerics or politicians we are used to hearing in the public sphere; but the language he uses is a mainstream language which people recognize, and his poetic performances are treated by many as a kind of supplement to the 'flesh and blood Brendan' whom they think they know. So, Kennelly's gift for communication and empathy is, on this view, emphatically not a voice crying in the wilderness for social change. Rather, the poetic agency of Kennelly's writing gains strength from his position as an authoritative and central cultural voice in Irish society. 
A prime example of Kennelly's willingness to intervene in the public sphere is to be found in his many media appearances, especially on the Late Late Show. Only those familiar with the sociology of Ireland in the I960s, I970s and I980s, as the country moved towards a more liberal and European social consensus and cast off the remnants of a conservative, Catholic social vision, can fully appreciate the centrality of that show to the transformational process. As Fintan O’Toole remarks:

It is the silences that have made Gay Byrne what he is in Ireland: the silences at the breakfast table, the silences around the fireside, the silences on the pillow. Without them he would be what he so patently is - a superbly professional broadcaster, confident, adaptable, quick thinking and fast talking - and no more. With them, he is something else altogether: the voice in which the unspoken can be articulated, the man who gives permission for certain subjects to be discussed. ${ }^{21}$

This insight could, of course, be applied to Kennelly himself and there is a certain synchrony between Byrne's broadcast persona and Kennelly's poetic persona, both of which are widely admired and appreciated by the Irish public. The same taboos which Byrne is credited with broaching in the TV studio find their way into Kennelly's poetry, and the targets of their social criticism are the same, chiefly politicians and the clergy. Section II of The Book of Judas (1991) is notable for its full-frontal critique of Church and State. Politicians are dismissed in three lines in the poem 'A Pitiless Scrubbing': 'My knowledge of politicians is limited / To the private but passionate conviction / They're more attractive dead than alive. ${ }^{.22}$ With equal insouciance, the Judas-voice lampoons institutionalized Christianity in a way which seems to anticipate the clerical child-abuse scandals of the I990s and the loss of authority of the Catholic church in Ireland. In 'A Motion', the Judas-voice suggests the Church needs to re-find an originary Christian humility: Kennelly (Tarset: Bloodaxe, 1996), 28.

22 Brendan Kennelly, 'A Pitiless Scrubbing', The Book of Judas A Poem (Tarset: Bloodaxe, I991), 332 . 
You take heaven for granted,

You need to get back in the gutter, you need

To bleed profusely for a while,

You need to dynamise your style, you need to admit

You're the Loser's Club before you're new again. ${ }^{23}$

In another heavy-handed sideswipe at the Catholic church, we are introduced to 'A Mystical Idea' of castrating members of the clergy:
Christy Hannitty thought it would be a blessing
If he cut the balls off all the Bishops of
Ireland because debollicked Bishops are less
Prone to the terrible temptations of love ... ${ }^{24}$

While we may agree with the sentiments behind these lines, it is hard to warm to the crudity of expression and tone. Kennelly's poetry is more admirable in his less strident poems, those which express sympathy for society's victims, often with simple but effective imagery, as in 'Children's Hospital' from the collection Begin (1999):
While things endure and break, while winter comes again and prowls morosely through dark places,
I read the clammy script of pain
on children's faces. ${ }^{25}$

If Kennelly's poetic voice seems sometimes compromised by the stridency of his public voice, his more aesthetically-nuanced poems are nonetheless persuasive as articulations of Irish social issues. The sequence 'Shelley in Dublin ${ }^{26}$ expresses similar sympathy for Dublin's dispossessed in an historical context made doubly relevant by the crudely acquisitive Celtic Tiger years and those they left behind.

23 Kennelly, 'A Motion', The Book of Judas, 332-3.

24 Kennelly, 'A Mystical Idea', The Book of Judas, 329.

25 Kennelly, 'Children's Hospital', Begin, 21.

26 Brendan Kennelly, Shelley in Dublin (Dublin: Anna Livia Books, 1974). Collected in Breathing Spaces: Early Poems (Newcastle: Bloodaxe, 1992). 
So what does the singular social entity Brendan Kennelly - as seen on TV - and as viewed through his published work, stand for in the public sphere? Åke Persson offers the following useful summary:

he speaks for tolerance and against intolerance; he seeks an inclusive society instead of an exclusive one; he insists on creating space for alternative voices in a society cherishing conformity; he passionately advocates a popularization of culture, opposing cultural elitism; and instead of silence he encourages dialogue. ${ }^{27}$

These are worthy values which Kennelly has done more than most to promote in Irish society. Kennelly's poetry may be said to confront issues associated with social inequality, the environment ('The Hope of Wings', 'Milk'), violence ('Hear the voice of the bomb,' 'Freedom Fighter'), illness ('The Children's Hospital', 'A Kind of Trust'), historical injustice ('My Dark Fathers', 'Am'). Despite all of this troubling material, he succeeds in offering us a life-affirming vision characterized by some of his best-known poems such as 'Begin' which concludes with the well-known quatrain:
Though we live in a world that dreams of ending that always seems about to give in something that will not acknowledge conclusion insists that we forever begin. ${ }^{28}$

More recently, Kennelly has produced books featuring very short poems and epigrams, including Glimpses (2001), Martial Art (2003) and Now (2006) which use brief, off-the-cuff wisdom, resembling the 'streetbites' pronounced by strangers in the Dublin streets, to convey a kind of worldly wisdom not unlike the popular genre of wisdom literature. There is a sagelike quality to these books wherein nuggets of ironic observation read as miniature re-castings of his expansive epic mode.

The question of the relative centrality of Brendan Kennelly in Irish social and cultural debates can be presented by analogy, specifically through the trope of the flâneur. This is a concept derived from Baudelaire and

27 Perrson, Betraying the Age, 227-8.

28 Brendan Kennelly, 'Begin', Begin, I04. 
subsequently theorized by Walter Benjamin. The flâneur strolls through the modern city and observes people and scenery; but he does so in a very detached and alienated way and according to Benjamin, he 'reads' the city as an outsider, somehow aloof from what is going on around him. In this way, the flâneur is a cultural trope for a certain type of alienated modern consciousness. ${ }^{29}$

It is well known that Brendan Kennelly enjoys walking, especially walking through the streets of Dublin. A newspaper review of The Essential Brendan Kennelly comments: 'a flâneur he has always been, this honorary Dubliner [...] Kennelly has constantly been out and about on the actual streets of the city. ${ }^{30}$ Part of Kennelly's pleasure in strolling around Dublin is his openness to the chance encounter. In a very Irish way, Kennelly is happy to meet and greet passers-by and to enjoy the pleasure of the passing moment and, above all, to be part of the social space through which he goes. Kennelly's poetry and his Prefaces to individual volumes are peppered with anecdotes - sayings and 'streetbites' - of things said by strangers he has happened to encounter. But the concept of the flaneur, as described by Baudelaire and Benjamin, differs somewhat from Kennelly's peregrinations; in fact, Kennelly's openness to the ordinary daily life of Dublin is an important statement against the trope of the flâneur showing that Kennelly's democratic art rejects the kind of alienation from mass society which Benjamin theorized and Baudelaire portrayed in his poems.

29 For example, in his 1929 essay 'The Return of the Flâneur', Walter Benjamin writes: 'It is here [Berlin], not in Paris, where it becomes clear to us how easy it is for the flaneur to depart from the ideal of the philosopher out for a stroll, and to assume the features of the werewolf at large in the social jungle - the creature of whom Poe has given the definitive description in his story "The Man of the Crowd." See: Walter Benjamin, Selected Writings II I927-1934, trans. Rodney Livingstone et al., ed. Michael W. Jennings, Howard Eiland, and Gary Smith (Cambridge, MA: Harvard UP, 1999), 265.

'Review: The Essential Brendan Kennelly', unsigned, The Irish Independent. < http:// www.independent.ie/entertainment/books/review-the-essential-brendan-kennellyed-by-terence-brown-and-michael-longley-with-cd-of-poems-read-by-author-2621235. html>. Accessed 2 July 2012. 
Declan Kiberd claims that Joyce also rejects a bohemian social space - which can be equated with the flâneur and his modernist anxiety - in favour of a much more conventional bourgeois social space. ${ }^{31}$ In Kiberd's reading, Joyce is less the detached artist creating an elitist masterpiece accessible to the educated few and much more of a democratic artist reclaiming the civic space of Dublin for its inhabitants. Recollecting the Dublin of his own youth, Kiberd argues:

The streets were then places which people felt that they owned, whereas seldom did they own their own houses, which Leopold Bloom likens to coffins. For him and for them, it was the public zone which was warm, nurturing and affirmative. It was there that the random encounters which propel Ulysses kept on happening, before the rise of the shopping mall put a brake on such unexpected meetings and an end to the idea of a neighbourhood. ${ }^{32}$

According to Kiberd, Joyce rejected the 'culture-worship' of the bohemian artist and his scorn for an art devoted to everyday life. By creating Ulysses as a riposte, Joyce famously demonstrated the miracle of the ordinary and the everyday.

It may well be that in his own epics, Brendan Kennelly is attempting something less than bohemian or counter-cultural and something more mainstream. Certainly, his public persona comes across as one at ease in conventional bourgeois social space, and lacking the aloof disdain of the Parisian flâneur. An examination of Kennelly's reinvention of the epic poem may assist in defining further the cultural location of Kennelly's poetry.

3I Declan Kiberd, Ulysses and Us: The Art of Everyday Living (London: Faber and Faber, 2009).

32 Kiberd, Ulysses and Us, 24-5. 


\section{The performative epic}

By achieving a breakthrough with the epic genre in the critically acclaimed volume Cromwell (1983) and the best-selling Book of Judas (1991), as well as Poetry my Arse (1995), Brendan Kennelly returned poetry to its most ancient roots and attained an unforeseen popular success in the process. Traditionally, the epic genre maintains a high-seriousness in its treatment of lofty subjects (such as justifying 'the ways of God to men'). ${ }^{33}$ Kennelly's success is based on his subversion of that high-seriousness into a kind of anarchic humour; even the more harrowing Cromwell contains humorous exchanges between Cromwell and Buffún. By tracing the epic to its ancient Greek roots, an insight is gained into the performative antics of Kennelly's poetic personae:

Epikos (Latin epicus; French épique; English epic) meant something having to do with epos - an interesting word in its own right which could mean 'a line of epic verse' or (in Homer) 'word, speech' and later could mean 'an epic poem' or even 'epic poetry' itself. The ancient Greek language itself, then, was keen to emphasise that epic was human speech, arranged into lines, assembled into poems, collectable as a genre. Even more interestingly [...] the Greek word muthos originally meant a 'speech act'; epic poetry was thus a type of myth not only in our modern sense of the word, but in the sense that it was language as action, assertion, announcement, attestation. ${ }^{34}$

One might suggest that Kennelly's vigorous Hiberno-English and his strongly vociferous protagonists - Cromwell, Buffún, Judas, Ace de Horner - embody these qualities of language as action and assertion. Indeed, the notion of the 'speech act' lies at the foundation of contemporary theories of performativity invoking as it does the 'speech act theory' of English

33 John Milton, Paradise Lost (Book I), 1667.

34 Jack Mitchell, 'The Genre of Performative Epic: a quasi-manifesto' <http://www. plainsofabraham.ca/>. Accessed 3 July 2012. 
philosopher J.L. Austin whose pioneering study How To Do Things With Words (1962) sought to establish the performative nature of language itself. ${ }^{35}$

All of Kennelly's protagonists are talkers and performers; the word and the deed change places frequently. The more garrulous the persona, the more often the word is the deed, or stands in place of the deed so that the disputes, interjections, extrapolations, prevarications are verbal actions and are central to the epic performance. The misfortunes of Irish history are associated with 'the curse of Cromwell' which is a verbal invocation or injunction based on the concrete deeds of Cromwell in his brief Irish campaign of 1649-1650. More generally, an enunciated curse fulfils the criteria for a 'speech act' in the technical sense J.L. Austin describes because, in making a curse, the words themselves accomplish the deed. Kennelly's reinvented Cromwell - part-historical, part-imaginary - is designed to give voice, even justification (however misplaced) for the deeds and massacres at Drogheda, Wexford and elsewhere. Likewise, we must listen to Judas and judge him by his words, not only his actions. In this manner, Kennelly balances notorious and much-mythologized deeds against a poetically instantiated verbal agency on the part of his protagonists and achieves a theatrically balanced interplay between word and action.

Kennelly as poet exhibits a bardic relationship to his materials. Intent on retelling Irish history through the voice of Cromwell, he reworks and thus reinvigorates traditional materials, in the best epic tradition of the rhapsodes of ancient Greece who reworked their Homeric epics. Likewise, the Biblical corpus, or at least the New Testament, becomes something quite different in Kennelly's bardic hands. If the purpose of literature is to defamiliarize language or to reinvent old tales by telling them slantwise,

35 John Langshaw Austin (1911-1960) was a British philosopher of language who held a Professorship in Moral Philosophy at Oxford University. He is remembered primarily as the developer of the theory of speech acts which he proposed in his book How To Do Things With Words (1962) based on the William James Lectures at Harvard University which he delivered in 1955 . For additional information concerning speech act theory, see James Loxley's book Performativity which contains a useful introduction to the thought of J.L. Austin. James Loxley, Performativity (London: Routledge, 2007), I-2I. 
then Kennelly's storytelling may be deemed a success, even if the more extreme riotous epic strategies of The Book of Judas and Poetry my Arse can sometimes weary the reader with their repetitive surrealism of event and action. Part of the problem with Judas, as compared with Cromwell, is that Cromwell's historical reality allows a useful grounded counterpoint to the more surreal aspects of the poem whereas, as John Goodby points out, Judas is largely 'ahistorical' and therefore Kennelly's imaginative fancies are unanchored and arbitrary and, at times, unsubtle and unfunny. ${ }^{36}$ Goodby levels the criticism that 'although Judas is a tour-de-force, it is, ultimately, a brilliantly bad book which runs away with its author'; ${ }^{37}$ while this may or may not be fair to The Book of Judas, it is certainly apt for describing the subsequent epic Poetry my Arse.

\section{Conclusion}

In considering the impact of Brendan Kennelly's poetry on the Irish public imagination, it has not always been possible to separate the poetic persona of Brendan Kennelly from the invented personae populating the poems, the Brendan Kennelly 'voices'. Both seem to enjoy a performative existence so that, as Lucy Collins points out, it is often impossible to make 'the distinction between performance of the poem and performance in the poem. ${ }^{38}$ Like the writings of a performance poet or songwriter, the poems make most sense when read aloud to an audience. This is one reason why, in this essay, the primary focus has been on the interplay between Kennelly the smiling public man and his talkative creations - the Kennelly voices. I82.

37 Goodby, 'History is What Hurts', 182.

38 Collins, 'Performance and dissent', 215. 
Those wishing to focus more minutely on the texts themselves can find ample critical support elsewhere. ${ }^{39}$

Those who criticize Kennelly for his alleged populism should consider that he is one of a handful of people in the literary establishment - including, perhaps, Paul Durcan, alongside public figures like David Norris or Gabriel Byrne - who can speak with authority on cultural and social issues in a sophisticated way and receive a hearing. He has done much to engage with and counteract the philistine materialism of modern Ireland and its economic obsessions as well as the illiberal tendencies of Church and State in the 1970 s and 1980 s. This is to be welcomed. Future critics may well consider Brendan Kennelly's participation in Irish public life as being at least as important and valuable as his poetic achievements.

39 Interested readers can find wide-ranging critical analysis of Kennelly's poetry together with ample bibliographical information in the following publications: Richard Pine, ed., Dark Fathers into Light: Brendan Kennelly (Tarset: Bloodaxe, 1994); John McDonagh, Brendan Kennelly: A Host of Ghosts (Dublin: Liffey Press, 2004); Gerold Sedlmayr, Brendan Kennelly's Literary Works: The Developing Art of an Irish Writer 1959-200o (Lampeter: Edwin Mellen Press, 2005). 


\section{Chagall, Balthus, Picasso, Lascaux: French Influences on Paul Durcan's Engagement with the Irish Public Imagination}

Born into a patrician family and counting among his relatives Maud Gonne, Major John MacBride and Seán MacBride, Paul Durcan has always been deeply engaged with the question of the Irish public imagination. In the public perception, Durcan's name has become associated with philippics against the perceived narrow-mindedness of senior Catholic clergy, the chastising of media self-righteousness and the lamenting of the visionless cowardice of some in political high office. All of this, allied with a raft of such overtly topical works as 'The Divorce Referendum, Ireland, 1986 ' and 'The Bloomsday Murders, 16 June 1997' attests to the poet's care for the moral and civic climate, for his country's imaginative life. At the root of his care for the tenor and content of civil and moral discourse is the implicit understanding, shared with theorist of nationalism Benedict Anderson, that each nation is 'an imagined political community.'

Durcan's world, in which public and private realms are seldom entirely distinguishable, is one where the social and epistemological centrality of imagination is paramount; a world where in reality fiction is all that matters.' Though the poet does invoke imagination, public and private, by name, more often the word 'dream' is used as a cognate to connote generative, creative space and activity. Hence, for example, we find both a terrorist with a 'dream gun blood-smeared' and innocent lovers who 'dreamed our

I Benedict Anderson, Imagined Communities: Reflections on the Origin and Spread of Nationalism (London: Verso, 2006), 4.

2 Paul Durcan, Daddy, Daddy (Belfast: Blackstaff Press, I990), 7 I. 
dreams of a green, green flag' in his 1978 volume Sam's Cross. ${ }^{3}$ The gunman and the couple represent opposite ends of the nationalist spectrum - their shared activity is the dream, their engagement in imagining Ireland. For both parties, as for all of us in Durcan's eyes, life itself is a dream, ${ }^{4}$ a creative and imaginative endeavour.

Aware of the essentially fictive and plastic qualities of public dialogue and imagination, Durcan has marshalled quite an array of liberating alternatives to oppressive forces in Irish society. From his earliest solo collection, he has described Ireland - and consequently its public imagination and discourse - as a 'country where words [...] have died an unnatural death / Or else have been used on all sides for unnatural ends.' His work, by implication and through example, argues for an alternative to such distortion of public imagination. Although it is not the primary subject here, a significant and noteworthy portion of Durcan's contribution to Irish public imagination was made through his weekly column for the Cork Examiner (1977-1982) as well as his editorship of The Cork Review (1979-1981). The focus in this essay is his poetry. Durcan's tactics for impacting upon the public imagination might be divided in three: comic and visionary subversion of constrictive realities, celebration of alternative figures and realities, and use of other cultures as mirrors in which examination of Irish realities can be conducted. Surely the apotheosis of the acknowledgement of Durcan's engagement with the public imagination came when his poem 'Backside to the Wind' was quoted by Mary Robinson at her inauguration as President in November 1990. Firmly part of the other-cultures-as-mirrors genre, 'Backside to the Wind' sees the speaker 'dreaming of a French Ireland.6 As Durcan imagines Ireland as it might have grown out of a successful French invasion in 1798 , contemporary and historical French 'Making Love Outside Áras an Uachtaráin' in Paul Durcan, Sam's Cross (Dublin: Profile Poetry, 1978), 56; 47. Paul Durcan, Life is a Dream: 40 Years Reading Poems 1967-2007 (London: Harvill Secker, 2009).

5 Paul Durcan, $O$ Westport in the Light of Asia Minor (London: Harvill, 1995), 63.

6 Durcan, Sam's Cross, I6. 
figures are invoked with reverence and awe: General Humbert, Rimbaud, les gendarmes. Whatever the significance of such political conjecture, French poetic and artistic influences on Durcan's own work are manifold and tangible. Connections can be drawn between Durcan and the works of Baudelaire and Rimbaud respectively; this is especially so in Durcan's writing of voices at home in the urban landscape, which has traditionally played second fiddle to more rural tableaux in the Irish public imagination. French cinema and philosophy have also been minor influences on Durcan's vision. However, it is on his engagement with French visual art particularly the works of Marc Chagall, Balthasar Klossowski (Balthus), the minotaur paintings of Picasso and the caves at Lascaux that the attention of this essay is focused, as Durcan himself has claimed that 'the experience of looking at pictures wherever I happen to find them" is essential to his practice as a writer.

Marc Chagall's influence on Durcan's work is both thematic and stylistic. Both men clearly retain a religious view of the world with their respective works being strewn with symbols and representative figures from their own faith traditions. In Durcan's case at least, this very much flies in the face of popular trends in the public imagination. Specifically, both Chagall and Durcan use the figure of the crucified Christ for sociopolitical purposes. During the Shoah, it was to the figure of the crucified Christ that Chagall - an orthodox Russian Jew - turned to in his art, as he painted fifteen crucifixions during the late 1930 s and early 1940s. Of these, 'White Crucifixion' (1938) and 'L'Obsession' (1943) remain the most striking, though perhaps more striking still is the very fact that a Jewish artist turned so obsessively towards this central Christian image as a representative symbol of Jewish suffering. An analogous use of the image of Christ, and the theme of his passion, is found in Durcan's work. Where Chagall, operating in a visual medium, used the figure of the crucified Christ, Durcan uses a much broader range of associated themes and techniques to impact on Irish public imagination. Durcan's depictions of persecuted Christ-like figures are ubiquitous, from his speaker in Endsville's 'The First Station, 
Perhaps' who laments being 'kissed and whipped in my native town'8 to I999s 'A Nineties Scapegoat Tramping at Sunrise' in which Bishop Eamon Casey and Charles Haughey are reimagined as Christ-like outcasts at the hands of the newly-ascended moral order of the smug Celtic Tiger years.

The use of the Christ figure as provocative and subversive template is put to best effect by Durcan as he questions Church power and authority. His dramatic poems are frequently verbal tableaux in which a powerful clerical or authority figure is shown in a predatory pose over another diminutive figure presented as a naif, a child, or in Durcan's favourite Blakean coinage, as an 'innocent'. A feeble and elderly mass-goer on the receiving end of a clerical tongue lashing in 1975s 'Pulpit Bishop Sickness, 1973' is depicted as having 'crucifixes of anguish crucify her face' as the eponymous Bishop delivers a sermon which is 'a knife in the ordinarily innocent face of life.' Similarly, a small girl - the sight of whom consoles the enraged speaker of 'The Divorce Referendum, Ireland, 1986' - is imagined as 'carrying in her breast the Eucharist of her innocence. ${ }^{10}$ This evocation of persecuted innocence, which has its parallels in Chagall, is made all the more subversive by Durcan's identification of clerics as the persecutors given their erstwhile exalted position in the public imagination of Irish Catholicism and of Irish society more generally. If this posture is today considered somewhat passé or even clichéd, it should be borne in mind that Durcan was employing these tactics as early as the mid-rig7os when the Church occupied quite a different, more dominant position in Irish life.

The centrality of innocence - etymologically a sense of being 'unwounded' - in Durcan's moral and epistemic vision has its cognates in Chagall's work. Eamon Grennan has noted how both Durcan and Chagall 'embody the extravagance of secular prayer in the comic mode. ${ }^{11}$ Furthering this observation, one might say that this effect is achieved by both artists via the capacious and emancipatory scopes of their respective visions. Just

8 Paul Durcan, Endsville, with Brian Lynch (Dublin: New Writers' Press, 1967), 25.

9 Durcan, $O$ Westport in the Light of Asia Minor, 64.

Io Paul Durcan, Going home to Russia (Belfast: Blackstaff Press, 1987), 27.

II Eamonn Grennan, 'Prime Durcan: A Collage', The Kilfenora Teaboy: A Study of Paul Durcan, ed. Colm Tóibín (Dublin: New Island, 1996), 53. 
as a Chagall painting (see for example 'Madonna with the Sleigh', 1947, or 'The Falling Angel', 1923-1947) can accommodate within one frame such disparate elements as a rabbi, a cock, village scenes, a fiddler, and a mother and child, so too Durcan uses subversive inclusivity as a tactic. One might describe Durcan's inclusion of usually disparate elements within a poem as a dissident act of imagination as it seems usually to have as its aim the shaking of our perceptions, the destabilizing of what we allow to pass for normality. Just as Chagall blends and incorporates disparate figures in one canvas, so too Durcan can, by a series of stealthy narrative moves, transport his readers. Strong examples of this include 'High-Speed Car Wash', 'The Day Kerry Became Dublin' (both from The Berlin Wall Café), 'Cot' (Daddy, Daddy), and 'Walking with Professor Dillon in the Old Agora in Athens' (The Laughter of Mothers). In 'The Day Kerry Became Dublin, ${ }^{12}$ the target of the poem's gentle humour is the contraction of public imagination into a discourse dominated merely by news headlines. In just under two dozen lines, Durcan transports his speaker from the workaday activity of 'reading gas meters in Rialto' and listening to the voice of 'a newsreader on the radio', to speculating on what it might be like to meet the Dalai Lama and 'to go to bed forever with the woman of my dreams.' The speaker's interlocutor in the poem is described as a woman in a green tracksuit, six feet tall, with nine children and living in a neighbourhood strewn with 'keeled-over, weeping dustbins'. Throughout the poem such naturalistic detail is repeatedly combined with fantastical flights of imagination. The statement that 'I heard a newsreader on the radio announcing / That the Bishop of Kerry had been appointed the Archbishop of Dublin' is followed immediately by 'I couldn't help thinking that her bottom / Seemed to be independent of the rest of her body'.

Similarly, it is useful to note how Durcan's incorporation of these disparate tonal registers - journalistic-descriptive and speculative-comic - within the canvas of the one poem creates the pleasant effect of comic disorientation. The reader is freed from the imaginative contraction of a world where newspaper headlines are central and dictate the tone and 
focus of discourse, and directed into a much richer emotional and psychic landscape. That both Chagall's paintings and Durcan's poems ultimately cohere as pieces of art is a testament to their respective visionary powers: both artists question and actively subvert the borders imposed by contractions and divisions in the public imagination.

'If there is solid ground in my poetry', wrote Durcan in 200I, 'I owe it partly to the thousands of hours I have spent before the paintings of Balthus and browsing his catalogues. ${ }^{13}$ This claim explicitly acknowledges an influence in operation in Durcan's oeuvre since he first encountered Balthus's work in Paris in the late r970s. Indeed, the influence of Balthus permeates some of the major inflections of the poet's engagement with the public imagination. As did Balthus, Durcan reworks sacral images in sexual or erotic terms, accentuating the often-suppressed affinities of these two typically discrete categories. Although this is clearly visible in Balthus's The Street (1933) which erotically reimagines the Piero della Francesca fresco The Legend of the True Cross (c. 1460), it is more striking still in The Guitar Lesson (1934), perhaps the most infamous of the painter's works. The painting, which depicts a prepubescent girl sprawled across the lap of an older woman, was inspired by the Villeneuve-lès-Avignons Pietà (c. 1470$)^{14}$ housed in the Louvre. The pietà image is reimagined here at Balthus's hand as perched delicately between depiction of sexual abandon and menace. In the comic blend of spirit and sex that is Durcan's 1978 poem 'Fat Molly', the speaker and the eponymous 'Molly' share an Eden-like idyll, with their erotic life described as a sweet crucifixion, crucified on each other'. Similarly, the later 'High-Speed Car Wash' pictures two passionate backseat lovers 'flowing into one another like Christ flowing into the Cross. ${ }^{16}$

This technique reached its peak for Durcan in his 1985 poem 'The Pietàs Over. ${ }^{17}$ Taking as his source material, as Balthus did in The Guitar Lesson, the culturally seminal image of Mary cradling Christ, Durcan uses

I3 Paul Durcan, Paul Durcan's Diary (Dublin: New Island, 2003), 40.

I4 Gilles Néret, Balthasar Klossowski de Rola: Balthus (London: Taschen, 2003), 8.

I5 Durcan, Sam's Cross, II.

i6 Durcan, The Berlin Wall Café, , $о$.

17 The Berlin Wall Café, 52. 
it to challenge and clarify the commonly-held image of marital breakdown. It is useful to remember that Ireland experienced two often bitterly divisive divorce referenda within a decade of the poem's publication. In a clever inversion, Durcan appropriates the perhaps stultifying pious image from traditional Catholic iconography in order to reignite the debate around the reality of the relationship of the sexes. Here, rather than a saviour figure, the poem's male subject is pathetic, self-absorbed and underdeveloped. Now being cut loose by his wife, he has spent his marriage 'Messiahing about in his wife's lap / Suffering fluently in her arms'. His wife, the speaker in the poem and the active agent in the marital situation, refuses to 'mollycoddle' her husband and instead insists that he has 'run the gamut of piety - / The Pietàs over'. The ground covered by the poem is of an intimate emotional landscape, but its import is political and imaginative too: men are unmasked as immature, dependent and harbouring a messiah complex; women on the other hand are strong, dependable, decisive. If Durcan is guilty of oversimplification it is surely deliberate and provocative, an attempt to jolt public imagination from its jaded postures.

Both Durcan and Balthus have toyed at length with the role and perception of the artist in the public eye. A Time magazine article in 1977, written to coincide with a Balthus show, remarked rather incredibly that 'at 69 he has no public face. ${ }^{18}$ Similarly when asked for some biographical matter for the catalogue of a 1968 exhibition at the Tate Gallery the artist replied curtly: 'Balthus is a painter of whom nothing is known. And now let us have look at the paintings. ${ }^{19}$ At one level an intensely private man, Balthus also engaged in a prolonged and rather mischievous campaign of persona fashioning, exploiting the modern public's fascination with the private lives and biography of artists. That an analogous strategy has been pursued by Durcan is perhaps less immediately obvious, yet no less evident upon closer inspection. Much of his work achieves a tone that is intensely personal and raw and is rendered as first-person lyric narrative which encourages the reader to identify the poet with the speaker of the 
poem. He has pursued a line of dramatic confessionalism in order to create his unique tone - especially in The Berlin Wall Café and Daddy, Daddy however, he has almost always been reluctant to expand upon on, verify or further contextualize details revealed in the poems. Moreover, unlike many of his contemporaries, Durcan's famed public readings seldom involve substantial introductions to his poems. This stripping away of context has multiple effects, one of which is to create the possibility of a dissociation of the gallery of personae contained in the poems from the author undertaking the reading. In this way 'Paul Durcan' - a frequent persona in Durcan's poems - can appear as just another literary trope in his gallery of nuns, priests, housewives, politicians and oddballs.

It is no coincidence that Durcan's award-winning Daddy, Daddy (1990), which was written after his father's death, begins with a poem detailing the funeral of a character named 'Paul'. In the piece, a priest enlists the poem's speaker as a mourner at a funeral he is conducting. Pressed for detail about the deceased, the priest responds: "He was about the same age as yourself, / All we know about him is that his name was Paul"' ${ }^{20}$ This wry observation - 'all we know about him is that his name was Paul' - might operate as a caveat to the presumptuous reader in just the same way as Balthus sought to warn viewers away from making biographical speculations regarding his work. Durcan has acknowledged this tendency in his own work, with specific reference to Balthus, in his 1999 poem 'Televised Poetry Encounter, Casa Fernando Pessoa, Lisboa' wherein he adopts yet another moniker, that of 'Tinkerly Luxemburgo':

I write

Under the pen name

Paul Durcan

But my real name -

Like Balthus

Or William Trevor -

Is Tinkerly Luxemburgo. ${ }^{21}$

20 Durcan, Daddy, Daddy, 3.

2I Paul Durcan, Greetings to our Friends in Brazil (London: Harvill Secker, 1999), 27. 
Given his explicit mention here, it might fairly be said that Balthus is at least one strong influence for this evasive and mystificatory tendency in Durcan's work, which here sees Paul Durcan mention 'Paul Durcan' while writing in the persona of 'Tinkerly Luxemburgo'.

And yet there is a marked strain of Balthus's work which simultaneously feeds an opposing impulse in Durcan's poetry. What is at question here is the often fraught distinction between public and private space in the public imagination. Even as both men disavowed directly biographical inferences in relation to their work, Durcan exploits the overly easy identification of his poetic persona with what is publicly known of his biography to create an occasionally unnerving sense of voyeurism in the reader. The viewer of Balthus paintings such as The Guitar Lesson (1934), Nude Before A Mirror (1955) or Alice (1933) is cast into the awkward position of being simultaneously enjoyer of a piece of art and voyeur of a scene of personal intimacy. Each painting features a naked or semi-naked body, a classical statement of vulnerability. In each case the figure is distracted by another activity. The residual effect for the viewer is one of transgression, a blurring of the line between what we imagine to be the postures of legitimate spectator and voyeur respectively. An analogous tension sustains much of Durcan's work, particularly his darker materials. A rehearsal of titles such as 'Notes Towards a Necessary Suicide, 'The Annual January Nervous Breakdown' and 'Valentine's Day'22 display the peculiarly intimate landscape carved out as his poetic territory. The key point here is that it is a landscape typically acknowledged as private in the public imagination. Exploiting this tension, Durcan toys with our perceptions around these subjects - just as Balthus did in the paintings named above - to create the dramatic frisson which is so easily identifiable as his characteristic poetic voice. It is his dramatic portrayal and poetic voicing of emotional vulnerability - rather than third person reportage of these states - that creates in his readers and listeners the air of transgression analogous to Balthus. This has become

22 From, respectively, Greetings to our Friends in Brazil, 92; Praise in Which I Live and Move and Have my Being (London: Harvill Secker, 2012), 156; and Cries of an Irish Caveman (London: Harvill Secker, 200I), I25. 
more pronounced over time, from the persona monologue 'The Haulier's Wife Meets Jesus on the Road Near Moone' (1985) through 'Man Walking the Stairs' (199I) to 'Notes Towards a Necessary Suicide' (1999) mentioned above. What other poet exposes us so graphically, often so unnervingly, to the sound of him or her 'listening to the booming of my own sobbing' ? ${ }^{23}$ His tendency to play with accepted divisions between public and private is succinctly summarized in his 2004 poem-couplet 'Leave the Curtains Open' from The Art of Life where Durcan pronounces on the paradoxes of his public-private personae. More apologia than poem, this epigrammatic piece acknowledges gleefully, in the same way that Balthus's art does, our most private and intimate moments as fit material for public performance. The opened curtains of the poem's title simultaneously reveal domestic and theatrical spaces.

In her 2003 essay $^{24}$ on Durcan's Cries of an Irish Caveman, Kit Fryatt interprets the poems through two major Irish literary lenses. She draws analogies between the title sequence of poems - in which Durcan imagines himself as a cow - and both the Old Irish epic poem Táin Bó Cúailnge and the seventeenth-century tradition which allegorizes Ireland as the 'Lost Heifer' or An Droimeann Donn Dilis. While acknowledging the veracity of Fryatt's interpretation, attention should also be drawn to two major French influences on this collection particularly and on Durcan's work more generally. These are, respectively, the minotaur etchings of Pablo Picasso and the cave paintings discovered at Lascaux in the Dordogne in 1940. In 'Cries of an Irish Caveman', the final section of Durcan's collection, he deals with the turbulence and breakup of a love relationship, speaking alternately in the voice of the eponymous caveman and in the voice of a cow in relationship with his controlling 'Cowlady. ${ }^{25}$ This extended self-portrait as a cow-man engaged in an erotic relationship is immediately reminiscent of Picasso's minotaur etchings undertaken from 1933-1935. Primarily an exploration of 4, ed, Fionnuala Dillane and Ronan Kelly (Dublin: Four Courts Press, 2003), 167-76. 
his affective life with his young lover Marie-Thérèse Walter, the symbol of the minotaur was later incorporated in his vast canvas Guernica (1937), so significant for the European public imagination in the twentieth century. In Picasso's minotaur series, themes of male menace, power and female subjugation are frequently central. ${ }^{26}$ To substantiate the connections between Picasso and Durcan, it is interesting to note that during the publication process of Cries of an Irish Caveman, twenty-three minotaur drawings were produced as potential cover images for the book. The style of these images is clearly imitative of the Picasso works and they are frequently marked by a violent and visceral quality. It is perhaps unsurprising then that none of them were deemed appropriate for the book cover, yet it is nonetheless significant that they formed part of the sizeable deposit made by Durcan to the National Library of Ireland in 2006.

The figure of the minotaur, imprisoned in a labyrinth and symbolic of suppressed psychic realities, has frequently recurred in the European public imaginary from the Heroides of Ovid onwards. It was central to the philosophic concerns of Durcan's contemporary and friend John Moriarty, who reproduced four of Picasso's minotaur etchings as keys to his immense 2006 work Night Journey to Buddh Gaia. ${ }^{27}$ Durcan's appropriation of the myth sees him enact a typically disorienting inversion. This inversion is very much of a piece with his subversive reimagining of perceptions of sex relations in the public imagination. In his rendering, the male of the relationship is not Picasso's overbearing beast but a diminished, emasculated and subjugated creature - in every sense cowed. The poet becomes variously 'Black Cow of the Family, 'Bullock with Cut Head' and a 'Desert Island Bull' while his powerful lover appears as 'Lady with Portable Electric Fence', and 'The Cattle Dealer's Daughter' revelling in 'The Camaraderie of the Mart'. Standard Durcan tropes are given a bovine twist - 'I am a middle of the

26 Josep Palau i Febre's 201 study Picasso: From the Minotaur to Guernica 1927-1939 (Barcelona: Ediciones Poligrafia, 20II) is an exhaustive account of this period in Picasso's life and has aided greatly in establishing links with Durcan's work.

27 John Moriarty, Night Journey to Buddh Gaia (Dublin: Lilliput Press, 2006), 9-I2 and passim. 
road cow' ('Bovinity'), 'The Black Cow of the Family' in a poem of that name, and 'I am the personification of innocence' ('The Second Coming').

His penchant for stylized self-pity notwithstanding, the most striking element of the collection is his depiction of the power-balance in the relationship. Durcan's persona is put through a series of comically humiliating postures: 'dribbling, excreting under the dry rain' ('The Happy Throng'), 'a stray cow amok in her flowerbeds' ('Love and First Sight') and experiencing premature ejaculation ('On the Brink of Her Ecstasy, He Collapses'). The poet's female lover, on the other hand is a frequently harsh, excoriating presence:

\section{When will you ever learn that Iran is not Iraq? \\ That the Hebrides are not the Orkneys? \\ That Mayo is not Mayo? \\ That in Brazil we do not speak Spanish? ? $^{28}$}

It is quite at odds with the (admittedly simplistic) perceptions of relationships which traditionally pervade the public imagination. Traversing a territory characterized by fifty shades of comic abjection, the cow and cowlady appear in relationships of slavery, power, guilt, control, domination, possession and other states from which our public discourse often recoils. Fryatt has noted that in many of these poems what Durcan treats is the theme of dispossession. More apposite to this study, she also notes that his broader project is one regarding the dispossession of certain modes of expression - the emotive, the tasteless, the sentimental - and his project is one of their recuperation to civilised discourse. ${ }^{29}$ It should be noted that her comments here are entirely consonant with the earlier remarks regarding the influences of both Chagall and Balthus on Durcan's art. Durcan has drawn from all three sources that which allows him to expand the thematic and expressive range previously deemed acceptable in Irish poetry.

29 Fryatt, 'Bovinity”: Paul Durcan's Cattle Mythology', New Voices In Irish Criticism 4,176 . 
'I'm not only a famous teaboy / I'm a famous caveman too' boasts the eponymous speaker of 'The Kilfenora Teaboy', ${ }^{30}$ the best-achieved early example of Durcan's now-characteristic melancholy persona monologue. 'I paint pictures by the hundred / But you can't sell walls' the speaker opines. This self-portrait as caveman has persisted: the cave has become a playful synonym for his domestic and creative space, reaching its most extended use in the Cries of an Irish Caveman selection. Rejected by his cowlady lover, Durcan reverts to his self-description as caveman. This image has several resonances in the public imagination, from the cartoonish fun of 'The Flintstones' to Hollywood depictions of primitive figures draped in shaggy animal skins and wielding stones or clubs in self-defence. One might assume that Durcan's use of it is in one sense self-deprecatory, drawing himself as an uncouth, backward figure. However, considering the poet's possession of a degree in archaeology, combined with his previous poetic invocation of archaeological structures such as Newgrange in A Snail In My Prime, one may suggest something more behind this usage. His persistent identification of his cave as the generative locus of his art is key. From his 1978 poem 'The Kilfenora Teaboy' which sees him painting on his cave walls to his 200 I claim that 'Drawing on my walls keeps me sane,, ${ }^{31}$ Durcan more than hints towards such cave art as was unearthed at Lascaux in 1940. This allusion is strengthened by the combination of the image of the cave artist in Cries of an Irish Caveman with the ubiquitous bovine imagery. There are several reasons why the Lascaux caves can be suggested to be central to Durcan's self-image as an artist: foremost of these is his long-term concern for the role of art and the artist in the public imagination. The sheer scale of the art uncovered at Lascaux (over 900 animals and almost 2,000 figures in all), combined with the obscurity of their original meaning and purpose, has combined to create an aura of gnomic significance about the complex of caves. These factors, added to the dating of the caves at c. I 8,000 years old, suggest an almost primal significance of art in human life. This is explicitly central to Durcan's general ethos. In a 1990 interview, addressing

30 Paul Durcan, Teresa's Bar (Dublin: Gallery Press, 1976), 50.

3I Paul Durcan, 'Cries of an Irish Caveman', Cries of an Irish Caveman, 89. 
the issue of insufficient state investment in education and the arts in Ireland in spite of lip service to the contrary, he said: 'Art is not something exterior to our lives, something that if we're reasonably affluent we can indulge in in our spare time - it is to do with what we are. Blood and bones and life and death. It is sustenance.32

The image of a Lascaux caveman is of a person for whom art and life are unified, unseparated by demands of social utility or economic dictates. To use Durcan's own anti-materialistic coinage, 'you can't sell walls'. Reading Lascaux as a prototype of an ideal unity between art and life, it is interesting to note how often, in Durcan's two ekphrastic volumes, he focuses on the location of art - of its production, its display and its consumption. He frequently addresses, in both Crazy About Women and Give Me Your Hand, the ways in which art has become divorced in the public imagination from the site of its production or its original usage. As Elizabeth Bergmann-Loizeaux has pointed out, these two Durcan volumes are as much examinations of the modern institution of the art gallery as they are about individual works of art. ${ }^{33}$ The solemnity of the gallery and its church-like demands for reverent quietude are often subverted. This is accomplished through the introduction of laughter, through prosopopoeiac poems in voices such as those of Van Gogh's mother ('A Cornfield with Cypresses') and an art gallery attendant ('Grief') and by a shift of focus to elements of the art work often considered marginal. ${ }^{34}$ Whereas Yeats's great late poem 'The Municipal Gallery Revisited' used art to muse reverently and retrospectively on major figures and fixtures on the Irish social and political landscape, Durcan reimagines the place of art itself in our lives and the role of the gallery in the public imagination now. Walking through the art gallery, Yeats sees politics, Durcan fixates on the politics of seeing.

Paul Durcan, interviewed by Arminta Wallace, Irish Times, io February 1990; article title: 'Live-In Poet', As.

33 Elizabeth Bergmann Loizeaux, Twentieth-century poetry and the visual arts (Cambridge University Press); see especially 'Private lives in public places: Yeats and Durcan in Dublin's galleries', 29-63.

34 For 'A Cornfield with Cypresses' see Durcan's Give Me Your Hand (London: Macmillan, I994), I35; for 'Grief' see Durcan, Crazy About Women, 137. 
If one tendency unites all of these instances in which Durcan is seen 'dreaming of a French Ireland', ${ }^{35}$ it is his tendency to test and playfully undermine the comfortable postures into which public thinking often slips. He has persistently sought to dissolve artificial barriers erected in the public square, be they political, spiritual, psycho-sexual or artistic. As Eamonn Grennan has written, 'with connectedness as its implicit theme, his work extends our sense of the world. ${ }^{36}$ In this art of extension, French influences have played no minor part.

35 Durcan, Sam's Cross, 16.

36 Eamonn Grennan, 'Prime Durcan: A Collage', The Kilfenora Teaboy, 72. 

PART IV

Haute Cuisine and High Society: Ça s'arrose! 



\section{French Boobys and Good English Cooks: The Relationship with French Culinary Influence in Eighteenth- and Nineteenth-Century Ireland}

'So much is the blind folly of this age that they would rather be imposed on by a French booby, than give encouragement to a good English cook!'

Taking Hannah Glasse's comments on French food and culinary prowess as a starting point, this chapter will consider the perception of French food in elite circles in Ireland in the eighteenth and nineteenth centuries, and to what extent it permeated Irish culinary discourse. Just as Glasse articulates a view of French cookery in the English imagination, it is interesting to examine some of the ways in which French cuisine and society were 'imagined' in Ireland.

Commentary on French cuisine by Glasse and her contemporaries has been interpreted as being more political in nature than founded on any real antipathy towards French culinary prowess, in particular in those recipe books that mark the shift from the aristocratic to the bourgeois paradigm. Lehmann, reviewing the various arguments as regards the extent to which French cooks and cuisine were fashionable and desirable in eighteenthcentury England, articulates her findings in a political frame, namely the existence of a close link between French cook and Whig employer: 'politics, even party politics, impinged on the dinner table.' An example of this is in the association of French chef Pierre Clouet with the Duke of Newcastle.

I Hannah Glasse, The Art of Cookery Made Plain and Easy, By A Lady. Facsimile of the first edition 1747 (London: Prospect Books, 1983 [1747]), v.

2 Gilly Lehmann, The British Housewife: Cookery Books, Cooking and Society in Eighteenth-Century Britain (Totnes: Prospect Books, 2003), 299. 
A preoccupation with French cookery was a burgeoning one amongst the political elite, notably the Whigs, who competed for the services of the most fashionable French cooks.

In Ireland, the Anglo-Irish gentry had their own 'rich and varied cuisine', with French chefs working in their kitchens to provide it. ${ }^{3}$ When Lady Emily Lennox, aged fifteen, daughter of the second Duke of Richmond, married James Fitzgerald, the twentieth earl of Kildare, she went to live in Ireland where, on discovering that her confectionary was to be made by a local housekeeper, she asked that her father find her a confectioner in Paris. ${ }^{4}$

The status accorded to French cuisine, and the circle it flourished in, was the target of satire in England. Indeed commentary regarding the status accorded to French cuisine was widespread by the end of the eighteenth century. The ironies involved were not lost on Catherine Wilmot, when she travelled from Ireland to Russia with her sister as guests of Princess Dashkov. In September I805, she remarks about elite circles in Russia 'there is something childishly silly in their reprobating Bonaparte when they can't eat their dinners without a French cook to dress it.'

Some understanding of the position accorded to French cuisine and associated concerns in Ireland is found in several different sources. The writings of Maria Edgeworth and the diary of Dorothea Herbert are of particular value. Also of interest are manuscript recipes, one of which is examined in this essay. It is unfortunate that one avenue of discussion just does not exist: prior to the twentieth century, there were possibly only three cookbooks by authors where there is a close connection with Ireland. None of them engage in commentary such as is found in the English books of the period, which is noteworthy in itself.

Máirtín Mac Con Iomaire, 'The Emergence, Development and Influence of French Haute Cuisine on Public Dining in Dublin Restaurants 1900-2000: An Oral History', Vol. 2, doctoral thesis (Dublin Institute of Technology, 2009), 50. Charles Henry Gordon-Lennox March, $A$ duke and his friends: the life and letters of the second duke of Richmond, Vol. 2 (London: Hutchinson, I9II), 682.

5 Marchioness Londonderry, The Russian Journals of Martha and Catherine Wilmot I803-I808, ed. H.M. Hyde (London: Macmillan and Co., 1934), I94. 
To use the term 'Irish' in the context of the history of Ireland prior to the foundation of the State, and increasingly in modern times, is to step into some of the most contested territory culturally, sociologically and politically. So for the purposes of this discussion it is necessary to understand that what is being discussed here is the food of the gentry and elites of the island of Ireland, categories that encompasses both the old Irish and Anglo-Irish classes in all their various manifestations.

\section{French cuisine}

Between I475, when Platina's De honesta voluptate et valetudine was published in Rome, and I651, when La Varenne published Le Cuisinier françois, there was a switch in the balance of power between France and Italy in the context of courtly cuisine. Books 6 to ro of Platina's work incorporate recipes that come directly from Libero de Arte Coquinaria, the work of the chef Martino of Como. Where Martino wrote in the vernacular, Platina used Latin. Platina's book ran to a second printing in its first year and subsequently appeared in at least fourteen other Latin editions, with a French edition published at Lyons in $1505 .{ }^{6}$ Martino influenced European cuisine for two centuries and was one of the first cooks to use sugar in large quantities to make dishes that are specifically sweet. ${ }^{7}$ This is noteworthy as an early example of the sweet/savoury binary that is a marker of postmedieval cuisine. ${ }^{8}$

Alan Davidson, The Oxford Companion to Food (Oxford: Oxford University Press, 2002), 735 .

7 Anne Willan, Great Cooks and Their Recipes: From Taillevent to Escoffier (New York: McGraw Hill, 1977).

8 Vanina Leschziner, 'Epistemic Foundations of Cuisine: A Socio-Cognitive Study of the Configuration of Cuisine in Historical Perspective', Theory and Society 35.4 (2006), $42 \mathrm{I}-43$. 
The switch to French supremacy can arguably be said to take place with the publication in 165 I of Pierre La Varenne's Le Cuisinier François. ${ }^{9}$ In La Varenne's book, 'the printed record of French cooking breaks decisively with the Middle ages', according to Barbara Wheaton. ${ }^{10} \mathrm{~W}$ ith La Varenne, there is the repositioning of sugar-based food to the dessert course at the end of the meal, and the articulation of what becomes the basic repertoire of French food in his recipes for bouillon, liaisons, farces and herb and spice mixtures, and the earliest recipe for roux. It is La Varenne who first proclaims the quality of Frenchness in a cookbook; others note that the fashionable diet is henceforth to be codified as French. ${ }^{11}$ French haute cuisine had now established its rules, its method and its 'Frenchness'.

What is noteworthy about the authors who followed La Varenne (such as de Bonnefons, de Lune, Massialot and La Chapelle) is the vitriolic tone adopted in their prefaces. A stance is taken that eschews any sense of collegiality with fellow practitioners, a trumpeting of culinary nationalism is overt, and 'the social connotations of food were being made more and more explicit. Good taste, national pride and deference to the court as the fount of all fashion. ${ }^{12}$ The court in question is the French court and this is not viewed with sympathy from across the water in England.

See Barbara Wheaton, Savoring the Past: The French Kitchen and Table from 1300 to ${ }_{1789}$ (New York: Simon and Schuster, 1983); Rachel Laudan, 'A Kind of Chemistry', Petits Propos Culinaires 62 (1999), 8-22; Amy Trubek, Haute Cuisine: How The French Invented The Culinary Profession (Philadelphia: University of Pennsylvania Press, 2000); Terence Scully, La Varenne's Cookery, The French Cook; The French Pastry Chef; The French Confectioner: A Modern English Translation and Commentary (Totnes: Prospect Books, 2006). Wheaton, Savoring the Past: The French Kitchen and Table from 1300 to 1789 , II5.

II See Priscilla Parkhurst Ferguson, Accounting for Taste; The Triumph of French Cuisine. Chicago: University of Chicago Press, 2004). Anita Guerrini, 'The English Diet: Roast beef and ... Salad?', History Today, 6r.2 (2011); Leschziner, 'Epistemic Foundations of Cuisine'.

I2 Stephen Mennell, All Manners of Food (Champaign, Ill: University of Illinois Press, 1996), 74 . 


\section{English attitudes}

In the history of printed cookbooks, France had a tradition of reprinting medieval texts, while England had a strong tradition of printing new works. From a relatively early stage, the English works were aimed at a wider readership. However, there were also books that were outside the normal run and more in the continental courtly tradition; in the period between 1660 and 1730 , they included books written by May, Rabisha, Lamb, Smith and Carter. These books do not address themselves to the wider society but rather to other professional cooks, and they are ostentatiously dedicated to their royal or noble patrons. In fact, these books mark the end of 'whatever little native tradition England had of 'courtly' cookery books. ${ }^{13}$

In the late seventeenth century, and through the eighteenth century, the bulk of successful English cookery books were those that articulated a sense of English food as being what may be described as country cooking at its best. In the main, such books were written by women. With respect to both style and authorship, English cookery books were now emerging as utterly distinctive from French ones. Gradually, these books did not just articulate a sense of being distinctive but would also come to see French food and 'French ways' as being inimical to the English way of life. The first authoresses include Hannah Wooley (1670), Eliza Smith (1727), Elizabeth Moxon (1749), Elizabeth Raffald (1769), and Hannah Glasse (1747). 'The intertwined themes of economy, plainness and hostility to French cookery are very prominent in these books. ${ }^{14}$ To be French is now to be castigated as extravagant, and to be modern in the French style is to have broken with the continuities of the past, to eschew the fine roasts and pies of the English tradition in favour of the delicate little kickshaws of France.

The cuisines of England and France can now be seen to have developed their own articulated styles: France has embraced culinary modernity; England has reacted by emphasizing the virtues of continuity, and with

I3 Mennell, All Manners of Food, 93.

I4 Mennell, 96. 
sustained criticism of French cooks and French food. It must be noted that, in reality, English writers absorbed many French dishes into their repertoire; however, whether in pursuit of commercial profit or through genuine national pride, these dishes are generally not acknowledged. Hannah Glasse provides a good example of the tone adopted,

A Frenchman, in his own Country, would dress a fine Dinner of twenty dishes, and all genteel and pretty, for the Expense he will put an English Lord to for dressing one dish. But then there is the little petty profit. I have heard of a Cook that used six Pounds of Butter to fry twelve Eggs; when everybody knows, that understands Cooking, that Half a Pound is full enough, or more then need be used; But then it would not be French. So much is the blind Folly of this Age that they would rather be imposed on by a French Booby, then give Encouragement to a good English Cook! $!^{15}$

\section{The Irish position}

When we talk about an Irish identity in food, we have such a thing, but we must remember that we belong to a geographical and culinary group with Wales, England and Scotland as all countries share their traditions with their next-door neighbour. ${ }^{16}$

In addition, it has been noted that in the late sixteenth and seventeenth centuries, Ireland experienced 'the largest immigration seen within Europe within the last eight hundred years, profoundly influencing indigenous traditions and often fusing them into new and distinctive patterns. ${ }^{17}$ In discussing the nature of diet, Louis Cullen distinguishes between the popular food sense, which he notes as being probably the poorest in Western Europe, and the traditions of hospitality and lavish entertaining amongst

Is Hannah Glasse, The Art of Cookery Made Plain and Easy, By A Lady. Facsimile of the first edition 1747 , ii.

I6 Myrtle Allen, Address at the opening of Ballymaloe Cookery School (I 4 November 1983).

I7 Louis Cullen, The Emergence of Modern Ireland (London: Batsford, 198I), I42. 
the elite classes. One French traveller to Ireland in the seventeenth century - just after La Varenne had revolutionized French cooking - shows how food in Ireland still maintained strong medieval links. He describes a salad put before him in the town of Dromore,

made according to the mode of the country, of I know not what herbs; I think there were sorrel and beets chopped together; it represented the form of a fish, the whole without oil or salt, and only a little vinegar made of beer, and a quantity of sugar strewed over it, that it resembled Mount Etna covered in snow, so that it is impossible to be eaten by any one not accustomed to it. I made my host laugh heartily in the presence of a gentleman, a lord of the town, on asking for oil to season this salad, according to the French fashion, and after having dressed it, I persuaded the gentleman to taste it, who was pleased to hear me speak of the state and customs of France, and told me he was extremely desirous of seeing France. ${ }^{18}$

That the relationship between Ireland, England and France was complex in its nature can be seen in Bishop Stock's narrative on the French invasion of Mayo in 1798. Stock, held captive in his castle by French officers under Lieutenant Colonel Charost, found the French ways of easy sociability much more congenial than those of their English liberator. They 'dined, drank and spent long evenings conversing together'. One of the threads running through Stock's narrative is the theme of food and conviviality, 'as he candidly admitted, during his captivity he had enjoyed fine food and excellent wine that the French had requisitioned from the cellars and larders of his loyal neighbours. ${ }^{19}$ Despite his allegiance to England, food and hospitality are the conduits that establish affection between the Church of Ireland Bishop Stock and his French gaoler.

Albert Jouvain, Description of England and Ireland under the restoration (I668), 42I. <http://www.ucc.ie/celt/published/Tioo075/index.html>. Accessed 6 December 2011.

I9 Caitriona Kennedy, 'Our Separate Rooms: Bishop Stock's Narrative of the French Invasion of Mayo 1798', Field Day Review 5 (2009), 94-107. <http://www.jstor.org/ stable.25664528>. Accessed 6 December 2011. 


\section{The picture painted by Maria Edgeworth (1768-1849)}

Older conventions of hospitality, which had been closely associated with abundance of food and drink, were gradually tempered after the Act of Union in 1800 , a change noted by Maria Edgeworth in The Absentee, when she writes about Dublin after the Union, and Lord Colombre's experience of it:

The hospitality of which the father boasted, the son found in all its warmth, but meliorated and refined; less convivial, more social; the fashion of hospitality had improved. To make the stranger eat to excess, to set before him old wine and old plate was no longer the sum of good breeding. ${ }^{20}$

In Ennui, Edgeworth has several observations to make about haute cuisine and she describes how the social cachet of having a French cook was a matter of some consequence to the elite classes. The protagonist, the Earl of Glenthorn, is a man of his time and he suffers from the fashionable disease of ennui:

The pleasures of the table were all that seemed left to me in life. Most of the young men of any ton, either were, or pretended to be, connoisseurs in the science of good eating. Their talk was of sauces and of cooks, what dish each cook was famous for; whether his forte lay in white sauces or brown, in soups, lentilles, fricandeaus, béchamel, matelots, daubes, etc. Then the history and genealogy of the cooks came after the discussion of the merit of the works; whom my lord C-'s cook lived with formerly - what my lord D- gave his cook - where they met with these great geniuses, etc. ${ }^{21}$

The Earl travels from Dublin with his 'own man' and his cook. Unsurprisingly, these are respectively an Englishman and a Frenchman, and the reader is treated to a vignette of the roadside antics of the pair with the Irish postilion, Paddy, when he takes charge of the chaise: in vain the Englishman

20 Maria Edgeworth, The Absentee (Oxford: Oxford University Press, 2002 [1812]), 82.

2I Maria Edgeworth, Castle Rackrent and Ennui (London: Penguin Classics, 1992 [1800]), 152 . 
in monotonous anger, and the Frenchman in every note of the gamut, abused Paddy. ${ }^{22}$

Alert to the subtle gradations of distinction between English, Irish and French pretensions, Edgeworth's tone is such that on balance she appears more at ease with French and Irish sensibilities. For example, again in Ennui, the Earl of Glenthorn remarks, somewhat approvingly of Lady Geraldine, 'her manner appeared foreign, yet it was not quite French. If I should have been obliged to decide, I should however, have pronounced it rather more French than English. ${ }^{23}$ Edgeworth locates contention between Ireland and England and not between Ireland and France, despite the fact that her family had been forced to flee their home in the autumn of 1798 in consequence of the French invasion of the west of Ireland. To complicate the issue further, the family had a chequered history in terms of denominational loyalty. ${ }^{24}$

It is the ruinous expense of the London season, rather than continental extravagance, which is at issue for Edgeworth. In The Absentee, Lord Colombre's father is faced with bankruptcy as a result of life in London and keeping up with the social pressures of the bon ton there. He exclaims to his son 'there need, at all events, be none of this, if people would but live upon their own estates and kill their own mutton. ${ }^{25}$ Like that other great commentator Mrs Delaney, Maria Edgeworth has a highly developed sense of 'appropriateness' as seen in the description of dinner at Mrs Raffarty's house, 'Tusculum':

The dinner had two great faults - profusion and pretension. There was in fact ten times more on the table then was necessary; and the entertainment was far above the circumstances of the person by whom it was given; for instance the dish of fish at the head of the table had been brought across the island from Sligo and had cost

22 Maria Edgeworth, Ennui, 170.

23 Edgeworth, Ennui, 203.

24 W.J. McCormack, 'Maria Edgeworth', Field Day Anthology of Irish Writing, Vol. I, ed. Seamus Deane (Derry: Field Day Publications, 199I), io52; see also W.J. McCormack. 'Introduction' in Maria Edgeworth, The Absentee (Oxford: Oxford University Press, 2001).

Maria Edgeworth, The Absentee, 66. 
five guineas; as the lady of the house failed not to make known [...] there was no proportion or fitness of things; a painful endeavour at what could not be attained, and a toiling in vain to conceal and repair deficiencies and blunders. ${ }^{26}$

Mrs Raffarty, the grocer's wife, is guilty of getting it wrong. For Edgeworth, social pretensions are not located in French culinary ways per se, but rather in the denial of the characters' own innate Irishness and in the grubby subterfuges involved. True conviviality is celebrated in Edgeworth's writings, for example in the description of the visit by Colombre to Count O'Halloran's castle in The Absentee, and the experience of dining there. Having feasted on eel-pie and 'Irish ortolans', and 'the delicate sweetmeat, the Irish plum', 'by the common bond of sympathy between those who have no other tastes but eating and drinking, the colonel, the major and the captain, were now all the best companions possible for one another. ${ }^{27}$

\section{Irish recipe manuscripts}

While the widespread practice of pirate publishing meant that many cookbooks were printed in Ireland during the period, there are still no relevant cookbooks of Irish authorship to which one can refer. ${ }^{28}$ As Ireland was, and is, an Anglophone country, the household books printed in Britain were widely available and marketed in Ireland. ${ }^{29}$ It is the nature of cookbooks that they seldom, if ever, appear in official library inventories. In the 1809 catalogue of the Clonbrock library, one of the more important landed

26 Edgeworth, The Absentee, 90.

27 Edgeworth, The Absentee, 122.

28 Constantia Maxwell, Dublin under the Georges I7I4-I830 (Dublin: Gill and MacMillan, 1979), 168.

29 Caitriona Clear, Women of the House (Dublin: Irish Academic Press, 2000), 68. 
estates, there is a record of 'Glasse's cookery'; however, by 1832, Glasse had disappeared. ${ }^{30}$

While it is to be expected that English cuisine would be the predominant cuisine in Ireland at the time, the issue is complex. The Anglo-Irish, with their variegated pedigree, harked back to an earlier era, promoting themselves as the last custodians of the hospitality of the old England. ${ }^{31}$ However, their rebuttal of parsimony has also been interpreted as an assimilation of traditional Gaelic standards of hospitality. ${ }^{32}$ Up to the Act of Union, Anglo-Irish society considered itself equal to the wider brotherhood of European aristocracy, where the standards of French haute cuisine prevailed. ${ }^{33}$ It is with this complex background in mind that a particular manuscript, Mrs Baker's manuscript, is a useful place in which to explore Irish assimilation of French culinary practice since it can be considered representative of the culinary practices of the gentry in Ireland.

Mrs Baker's manuscript is a fine compendium of recipes. ${ }^{34}$ Originally one of two volumes, the second one not known to be extant, the manuscript was bought from a Dublin bookseller by the late Dr Monica Nevin and donated to the National Library. The book bears the inscription 'Mrs A.W. Baker's Book, Vol. ist, Ballytobin, County Kilkenny':

The Bakers of Ballaghtobin were, no doubt, typical of many Anglo-Irish families who were content to live on their estates. Since they never held high office nor sent a member to Parliament references to them in either printed or manuscript sources are few. ${ }^{35}$

MS 19,947 National Library of Ireland; MS 19,948 National Library of Ireland.

3I See T.C. Barnard, 'The Gentrification of Eighteenth Century Ireland', Eighteenth Century Ireland-iris an dhá chultúr I2 (1997), 137-55.

Katharine Simms, 'Guesting and Feasting in Gaelic Ireland', Journal of the Royal Society of Antiquaries of Ireland 108 (1978), 67-100.

33 Máirtín Mac Con Iomaire and Dorothy Cashman, 'Irish Culinary manuscripts and printed cookbooks: A discussion', Petit Propos Culinaire 94 (2011), 8I-IOI.

34 Mrs Baker, MS 34,952 National Library of Ireland.

35 Monica Nevin, 'A County Kilkenny Georgian Household Notebook', Journal of the Royal Society of Antiquaries of Ireland, 109 (1979), 5-19. 
They did indeed live upon their own estates and kill their own mutton, to quote Lord Colombre's father.

In the manuscript, La Varenne's Soup à la Reine features as 'Almond Soup', otherwise known as 'White Soup'. Readers of Jane Austen will be familiar with white soup from Pride and Prejudice (1813): when Charles Bingley declares his intentions to hold a ball, 'but as for the ball, it is quite a settled thing and as soon as Nicholls has made white soup enough I shall send around my cards. ${ }^{36}$ Originally known as Pottage à la Reine, it first appeared in La Varenne. The essence of this pottage is the bouillon produced by boiling the bones of fowl. It is a recipe that appears regularly in manuscripts, in a bewildering variety of forms, sometimes with the addition of vermicelli in place of almonds. ${ }^{37}$ Mrs Baker's white soup is a fine veal stock soup enriched with almonds and served with 'a French Roll stuck with almonds and stewed in a little of the soup in the middle'. French bread was made by enriching yeast dough with milk, butter, or eggs, and was the most highly regarded bread of the time. ${ }^{38}$ Mrs Baker's recipe for the French way of making leaven is extensive, and she remarks that in the shaping, the dough 'must be neither dauked [sic] (possibly: docked), nor opened on the sides as is the custom in Ireland'. Jane Austen captures the status of French bread in an exchange between Mrs Morland and her daughter in Northanger Abbey when Mrs Morland reproves her daughter, 'where ever you are you should always be contented, but especially at home, because there you must spend most of your time. I did not quite like, at breakfast, to hear you talk about the French bread at Northanger. ${ }^{39}$ On the evidence of Mrs Baker and other Irish manuscripts of the period, French bread is accorded the same respect in Ireland.

Mrs Baker's manuscript is representative of the Irish culinary manuscripts I have studied, and is in fact more comprehensive than most. There is no commentary that could be construed as disparaging regarding French

36 Jane Austen, Pride and Prejudice (London: Penguin Classics, 2003 [I8I3]), 54.

37 Scully, La Varenne's Cookery, The French Cook; The French Pastry Chef; The French Confectioner: A Modern English Translation and Commentary, I39.

38 See Maggie Lane, Jane Austen and Food (London: Hambledon Press, 1995).

39 Jane Austen, Northanger Abbey (London: Penguin Classics, $201 \mathrm{I}$ [I8I7]), 225. 
food or manners. This is consistent with the impression posited, that the Irish elites were more concerned with the status of their own position $v i s-\dot{a}$-vis their peers across the Irish Sea. Their place in the social hierarchy was sited within the context of Anglo-Irish relations, despite or even perhaps feeding off, a certain regard for French culture. However, what is apparent is the conjoining in the popular imagination of France with culinary concerns, and by extension the gentle stereotyping of the excitable French chef by Edgeworth. This stereotyping is bonded closer to profligacy and excess in English commentary and may in part be traced back to the famous chef François Vatel, and the report of the extravagant banquet in honour of Louis XIV held at Chantilly, where the chef was reported to be so distraught about the tardiness of a seafood delivery that he committed suicide. No doubt, this stereotyping was part of the reason that King William IV, the last king and penultimate monarch of Britain's House of Hanover (Queen Victoria was the last monarch), dismissed his brother's French chefs on accession; to public approval, he replaced them with English ones.

\section{Dorothea Herbert's diary}

Dorothea Herbert kept a diary, or 'retrospections', for the last decades of the eighteenth century, and the early years of the nineteenth century. The original manuscript is held in Trinity College Dublin. Herbert has much to say concerning social life in the upper levels of country society at the time, both in her native Carrick-on-Suir and further afield. She records that in 1775 , her mother being subject to:

Nervous Fevers was forced to take a French governess for us - we did not much relish this but with the help of the young Jephsons we kept her in proper subjection - they also had a French governess and the two Mademoiselles soon found 
conciliating manners more efficacious than rough work - their names were Charles and Delacour. ${ }^{40}$

She also recounts that the Herberts at Muckross had a French Cook who 'dressed our dinner under the trees which we eat very merrily till the fire caught some combustible matter on the mountain which blew up about us with a hideous explosion., ${ }^{41}$ Dorothea's father, Nicholas, was the eighth of nine children of the Herberts of Muckross. Their connection with Kerry began in 1656, and they acquired the lands at Muckross in 1770, following the death of a MacCarthy relation. One of the more bizarre incidents related by Dorothea is of the arrival on Saturday 2 June 1782 , of an old French woman who:

came begging to us cover'd with Rags and Sores - My Mother took her in out of Charity and bought her two Cotton Negliges - she taught us all French capitally, and as capitally taught us to make Mushroom Soup and Soup Maigre - it was our chief amusement after our lessons to gather Mushrooms and Herbs for our Regale - with her good will she would have superadded Frogs etc but we declined that part of it. Madame Bondagée being a Parisian had a remarkably good Accent and a good notion of teaching French grammatically - she was an enthusiast for her pauvre Ro $i$ as she termed the French king and gave us such an account of the attachment of the French for their Sovereign that none should suppose they would murder him and all his family shortly after as happened in the French Revolution [...] she fell into drinking and then there was no bearing her Tempers and Vagaries. ${ }^{42}$

Herbert also gives details of the fête champêtre held in 1793 at Caher. Her hostess was Lady Caher, the former Emily Jeffreys of Blarney Castle, who that year had married Richard Butler, twelfth Baron Caher. The couple were respectively aged sixteen and seventeen, which lends credence to Dorothea's description of Lady Caher dancing 'an Irish Jig for us in her Stockings to the Musick of an old blind piper - all was conducted in the Old Irish Stile - Lord Caher and she did everything to make it agreeable

40 Dorothy Herbert, Retrospections of Dorothea Herbert 1770-I806 (Dublin: Town House, 2004), 25.

4I Herbert, Retrospections of Dorothea Herbert 1770-1806, I52.

42 Herbert, 83. 
to each individual Guest. ${ }^{43}$ The fête champêtre was a popular form of outdoor or pastoral entertainment, originating in the eighteenth century at Versailles. Maria Edgeworth mentions it in her play The Rose, Thistle and Shamrock (1817) when Miss O'Hara describes her plan for decorations for the evening entertainment, 'Yes, here is the shamrock - the rose, the ever blowing rose - and the thistle. And as we are to have Scotch, English, and Irish at our little fête champêtre this evening, don't you think it would be pretty to have the tents hung with the rose, thistle, and shamrock joined.' ${ }^{44}$ Lord and Lady Caher developed this form of entertainment in later years and they commissioned the famous Regency architect John Nash to design a cottage orné in the grounds of Caher Castle in which they used to entertain their guests in the pastoral style of the French court. This is one of several such entertainments which Dorothea Herbert attended, and her accounts give some idea of the assimilation and popularity of this particular French form of entertainment. About the fête champêtre held by Simon Osborne at Annfield she comments 'we dined under tents and Marquees on the lawn - nothing could exceed the elegance of the entertainment'; ${ }^{45}$ and about Mrs Cooke, a widow and the daughter of Lord Desart, she comments, 'her admirers gave us constant fête champêtres. ${ }^{46}$

In Herbert's description of a party for a housewarming in the summer of 1793 , she gives further evidence of the fact that French taste was the le nec plus ultra, even as far as rural Bonmahon:

Miss Butlar, Miss Blunden and Fanny manufactured the Whips jellies and Creams and I made a Central Arch of Pasteboard and Wild heath with various other ornaments and Devices - In short a more flaming affair never was seen on the Banks of the Seine - what must it have appeared on the banks of the Mahon. ${ }^{47}$

43 Herbert, 325.

44 Maria Edgeworth, The Rose, Thistle and Shamrock, Act II, Sc.I. In Maria Edgeworth, Comic Dramas in Three Acts (London: R. Hunter, 1817 ).

45 Herbert, II2.

46 Herbert, 8I.

47 Herbert, 3 II. 


\section{Conclusion}

In exploring evidence of engagement with French culinary hegemony in Ireland, the discussion so far has been situated within the wider context of how French cuisine developed and was perceived by Ireland's political overlords. In many ways, culinary discussion centred as much around political prejudices as it did on gastronomic issues. Irish concerns tended towards fretting over issues of hospitality and making 'the grand figure', and these seem to have overshadowed political party allegiances. Elizabeth Bowen has described the Anglo-Irish class under discussion here as isolated, it is an affair of origin. ${ }^{38}$ Perhaps this is another reason why discussion surrounding conviviality and hospitality assumed such proportions. Certainly the evidence is that the Anglo-Irish maintained strong links with their continental neighbours in France and that, for them, there was less unease surrounding the fact that it was French standards that carried the highest social cachet, imaginatively and actually.

48 Elizabeth Bowen, Bowen’s Court (London: Longmans, Green, 1942). 


\section{Ireland in the Georgian Era: \\ Was There Any Kingdom in Europe So Good a Customer at Bordeaux?}

Irish wine

Many different wines were available in eighteenth-century Ireland, but the consumption of the red wine of Bordeaux, commonly called 'claret', was an integral element of élite socializing and dining. In the public imagination in Ireland, as elsewhere at that period, France was the recognized arbiter of gastronomic matters. Even if her influence in this sphere was sometimes parodied or criticized, her wines were esteemed above all others. ${ }^{1}$ This fact, operating in conjunction with Irish links with Bordeaux - particularly those established in the late seventeenth and early eighteenth centuries served to influence élite consumer perception of, and preference for, its red wines, and resulted in a marked predilection for claret by Ireland's privileged classes throughout the Georgian period.

In the modern era, stout, whiskey, and poitin are the alcoholic beverages most closely associated with Ireland in the public imagination. Today's modern consumer, whether French or Irish, is largely unaware of the fact that long before 'la Guinness' established its iconic relationship with Ireland's drinkers, claret was the gentleman's tipple depréférence. The

I See Dorothy Cashman, previous chapter; see also Hannah Glasse, The Art of Cookery Made Plaine and Easy, By A Lady (London: W. Strahan, J. \& F. Rivington, J. Hinton, I774), iv; Stephen Mennell, All Manners of Food (Champaign, Ill: University of Illinois Press, 1996), 96. 
red wine of Bordeaux was consumed so widely and with such relish by Ireland's nobility and gentry in the eighteenth century that Dean Swift, in a personal letter, playfully referred to it as 'Irish wine', confident that his correspondent would recognize the term as denoting claret. ${ }^{2}$ Claret, though also a preferred wine in England in this period, often ceded its popularity there to that of port, due to varying political and trade issues throughout the eighteenth century. ${ }^{3}$ In Ireland, the enthusiasm for claret strengthened apace with the century. A high tax on port in the 1780 s ensured that claret's appeal did not wane. ${ }^{4}$ For Ireland's Georgian-era élite, the real impetus behind claret consumption can be ascribed to its members' susceptibility to the imperatives of native standards of hospitality and, as mentioned by Dorothy Cashman in this volume, their delight in 'projecting the grand figure.' As T.C. Barnard explains, privileged members of Georgian Irish society shared 'a preoccupation with making the right impression [...] with many contemporaries throughout Europe and America: ${ }^{6}$ A period of relative political calm and increasing prosperity allowed those in the upper echelons of society (and some in its growing middling ranks) to steer Dublin to the position of second city in the Hanoverian empire. ${ }^{7}$ Only gentlemen (and ladies) of 'figure and fortune' were in a position to benefit from the social and material delights that a prosperous Dublin could offer - particularly in the latter half of the century. The members of this privileged social stratum comprised: aristocratic estate owners,

2 Jonathan Swift, Letters Written by the Late Jonathan Swift, D.D., Dean of St. Patrick's Dublin, and Several of His friends from the Year 1710 to 1742 , ed. Deane Swift (London: C. Bathurst, W. Woodfall, W. Strahan et al., 1768), 23. Charles Ludington, 'Politics and the Taste for Wine in England and Scotland: I660-I860', PhD thesis (Columbia University, New York), 2003.

4 James Kelly, 'The Anglo-French Commercial Treaty of 1786: The Irish Dimension', Eighteenth-Century Ireland/Iris an dá chultúr, 4 (1989), 99.

5 See Dorothy Cashman, 'French Boobys and Good English Cooks: The Relationship with French Culinary Influence in Eighteenth- and Nineteenth-Century Ireland', in this volume.

6 Toby Barnard, Making the Grand Figure: Lives and Possessions in Ireland, $1641-1770$ (New Haven: Yale University Press, 2004), xxi.

7 Barnard, Making the Grand Figure: Lives and Possessions in Ireland, $1641-1770$, xviii. 
military officers, Anglican clergy, politicians, lawyers, bankers, landed gentry, gentlemen farmers and wealthy merchants. The majority of the members of these groups would have been of 'Old' or 'New English' lineage, whereas Catholics were by and large of ancient Irish lineage, i.e., Gaelic. Nonetheless, in the context of this study the adjective 'Irish' will frequently be applied to the country's Georgian élite. Such a simplistic application is open to debate, but the focus here is to consider the historiography of a specific gastronomic element of material culture, claret, in the context of a specific time and place; thus there will be no engagement in socio-political or historical rhetoric.

Many wines were available to the eighteenth-century Irish lord or gentleman, from Canary to Rhenish. ${ }^{8}$ Why then did claret achieve a position of social and gastronomic significance in Ireland that endured throughout the long Georgian era? The answer lies in the alignment of various political, social, cultural and economic factors which created the ideal conditions for claret's universal popularity amongst the ascendancy classes and for a minority of middle to upper-class Roman Catholics who generally had direct trade links with Bordeaux. ${ }^{9}$

8 Máirtín Mac Con Iomaire and Tara Kellaghan, 'Royal Pomp: Viceregal Celebrations and Hospitality in Georgian Dublin', Celebration: Proceedings of the Oxford Symposium on Food and Cookery 2oII, ed. Mark McWilliams (Totnes, Devon: Prospect Books, 2012), I65.

9 See Leslie A. Clarkson, 'Hospitality, housekeeping and high living in eighteenthcentury Ireland', Luxury and Austerity, ed. J. Hill and C. Lennon (Dublin: University College Dublin Press, 1999), 84-105; Louis M. Cullen, 'The Dublin Merchant Community in the Eighteenth Century', Cities and Merchants: French and Irish Perspectives on Urban Development, I50o-I9oo, ed. Paul Butel and Louis M. Cullen (Dublin: Department of Modern History, Trinity College Dublin, 1986), 195-209; Richard Hayes, 'Les Familles en Exil' in Les Irlandais en Aquitaine, ed. Richard Hayes, Christopher Preston and Jacques Weygand (Bordeaux: Héritiers E.-F. Mialhe, 197I), 29-44; James Kelly, 'The Anglo-French Commercial Treaty of 1786 : The Irish Dimension', Eighteenth-Century Ireland/Iris an dá chultúr. 4 (1989), 93-III. 


\section{Turning misfortune into fortunes in Bordeaux}

Strong Irish links with Bordeaux had been established before the eighteenth century. Richard Hayes notes that there was an active trade with Bordeaux in the sixteenth century, ${ }^{10}$ and an Irish College was founded at Bordeaux in 1603 . It was, nevertheless, during the eighteenth century that socio-economic links between the port of Bordeaux and ports of southern Ireland reached a new level of importance. Patrick Clarke de Dromantin points out that the influx of les oies sauvages into late seventeenth-and early to mid-eighteenth-century France occurred as a result of three distinct waves of emigration. ${ }^{11}$ The most significant of these followed the Jacobite defeats at the Battle of the Boyne (1690) and the Battle of Aughrim (169r), with two further waves following attempts at a Stuart restoration in 1715 and 1745 . The approximately 50,000 Jacobite émigrés were primarily comprised of gentilhommes whose subsequent careers in France tended to be either military or mercantile in nature (and, in the case of a few prominent Catholic families, ecclesiastical). Numerous sources credit members of the Wild Geese with playing a remarkable role in eighteenth-century French commerce, establishing businesses in the main ports on the Atlantic seaboard - most significantly in Nantes and Bordeaux. ${ }^{12}$ The latter city had the distinction of sheltering an Irish colony notable for its dynamism. ${ }^{13}$

Io Richard Hayes, 'Irish Links with Bordeaux', An Irish Quarterly Review 27. 106 (1938), 293.

II Patrick Clarke de Dromantin, Les Oies Sauvages: Mémoires d'Une Famille Irlandaise Réfugiée en France, Nantes, Martinique, Bordeaux: I6gI-IgI4 (Bordeaux: Presses Universitaires de Bordeaux, 1995), I6.

I2 See for example, Guy Chaussinand-Nogaret, Une histoire des élites 1700-1848 (Paris: Mouton Editeur, 1975); Louis M. Cullen, The Emergence of Modern Ireland, I60o1900 (London: Batsford, 198I); Richard Hayes, 'Les familles en exil' Les Irlandais en Aquitaine, ed. Richard Hayes, Christopher Preston and Jacques Weygand (Bordeaux: Héritiers E.-F. Mialhe, 197I), 29-44.

I3 See Clarke de Dromantin; see also Richard Hayes, 'Liens Irlandais avec Bordeaux', Les Irlandais en Aquitaine, 3-18. 
Notwithstanding the fact that Dublin's expatriate communities may have been insignificant in comparison to those of Bordeaux, Louis Cullen observes that a combination of Scottish Presbyterians working in association with Huguenot refugees was responsible for growing Georgian Dublin's wine trade with Bordeaux in the first half of the eighteenth century. ${ }^{14}$ The Huguenots carried their taste for French wine to other parts of Ireland: J.L. McCracken states that in Waterford the Huguenots participated in the wine trade; ${ }^{15}$ and Erasmus Borrowes notes that Huguenot refugees from Bordeaux drank 'the prized beverage of their own native land.' ${ }^{16}$

The fact that Irish Catholic merchants were excluded from participation in the lucrative wine trade with Bordeaux for the first half of the eighteenth century is not surprising. The Catholic Dillon and Lynch families were two notable exceptions to this professional ostracism. The Dillons profited from family and banking ties to Ireland, and strong links to the Bourbon court. Lieutenant-Colonel the Honourable Arthur Dillon followed James II to France in $1690,{ }^{17}$ where one Dillon fils became Archbishop of Narbonne and a grand-daughter became the Marquise de la Tour du Pin. The Lynch's direct family ties to Galway helped to gain them the advantage in the wine trade with the west of Ireland. ${ }^{18}$ They became one of the pre-eminent families involved in the commercial and political life of Bordeaux for over a century, eventually rising to the ranks of the French peerage through their industry. The wine of Lynch-Bages perpetuates the family name to this day. ${ }^{19}$

I4 Louis M. Cullen, 'The Dublin Merchant Community in the Eighteenth Century', 198 .

I5 J.L. McCracken, 'The Social Structure and Social Life, I7I4-60', A New History of Ireland: Eighteenth-Century Ireland I69I-I800, ed. T.W. Moody and E.W. Vaughan (Oxford: Oxford University Press, 2009), 4I.

I6 Erasmus Borrowes, 'The French Settlers in Ireland: No. 8, The Huguenot Colony of Portarlington', Ulster Journal of Archaeology i. 6 (1858), 339.

17 Richard Hayes, 'Biographical Dictionary of Irishmen in France', An Irish Quarterly Review.31. I24 (1942), 485-6.

I8 Cullen, 'The Dublin Merchant Community in the Eighteenth Century', 198.

I9 T.P. Whelehan, The Irish Wines of Bordeaux (Dublin: The Vine Press, 1990). 


\section{The Winegeese spread their wings}

It was Ted Murphy who coined the term 'Winegeese' to denote the Wild Geese who became involved in the wine trade in France, and for whom Bordeaux became 'home' - not simply in the physical sense but also spiritually and culturally. ${ }^{20}$ However, Irish merchant émigrés were initially obliged to live and work outside of the city walls - a restriction then imposed upon all foreigners. Settling on the waterfront on the Quai des Chartrons, many of the Irish Chartronnais (as the foreign merchants came to be distinguished) rose to be the greatest of the city's wine brokers. By the mid-eighteenth century, the Irish Chartronnais had become the most influential expatriate community in Bordeaux. ${ }^{21}$ Referring to that latter group, Clarke de Dromantin observes that 'Grâce à leur dynamisme et à leur énergie, ils ont su retrouver leur place dans les élites des nouvelles patries qui avaient bien voulu les accueillir. ${ }^{22}$ Further, he credits the Irish nobility who took refuge in France with spurring an interest in commerce in the native noblesse:

L'influence des Jacobites sera déterminante sur l'évolution des concepts de l'aristocratie française tout au long du siècle des lumières et c'est en partie grâce à eux que la noblesse française se lancera avec ardeur dans les nouvelles activités économiques commes les mines, le textile, la chimie, la sidérugie ou l'industrie métallurgique naissante. C'est ainsi que la noblesse de France apparaît au XXVIII ${ }^{\mathrm{e}}$ siècle comme une classe sociale entreprenante et dynamique contrairement à l'image de marque rétrograde largement répandue dans les manuels d'histoire. ${ }^{23}$

Although his list is not exhaustive, Hayes enumerates Irish families who achieved positions of social prominence in Bordeaux: Lynch, MacCarthy,

20 Ted Murphy, A Kingdom of Wine: A celebration of Ireland's Winegeese (Cork: Onstream Publications Ltd., 2005).

2I Murphy, $A$ Kingdom of Wine: A celebration of Ireland's Winegeese, 4I.

22 Clarke de Dromantin, Les Oies Sauvages, 20.

23 Clarke de Dromantin, I9. 
Dillon, O'Byrne, Ffrench, Galway, and Kirwan. ${ }^{24}$ To these can be added the names of Barton, Lawton, and Johnston, three Anglican families that were numbered amongst the most successful in the wine trade; through their relatives and business connections, they achieved levels of success that helped them wrest the custom of Ireland's most prominent families from Scottish Presbyterian wine merchants by the mid-eighteenth century. ${ }^{25}$

It is important to note that Hiberno-French merchants did not depend solely on their former compatriots for business: their list of clientele included the illustrious in England, and later in America. In I714, when James Brydges, ist Duke of Chandos, was made Earl of Carnarvon, he marked his elevation by placing an order of wine comprising 'six hogsheads of luxury claret, two of burgundy and two of champagne' with the Irishborn Richard Cantillon, and a further six hogsheads of 'the best Bordeaux' from Bordeaux-based Irishman, Thomas Walsh. ${ }^{26}$ On a visit to Bordeaux in 1785 , Thomas Jefferson sought advice on stocking his Paris wine cellar from Abraham Lawton, originally from Cork. The Johnston family consolidated Bordeaux-Irish links with America's political and social elite: a family member was despatched to North America in 1807 , and courtesy of the Marquis de Lafayette, this hibernois was armed with a letter of introduction to George Washington's secretary - General McHenry, another Irishman. Such prestigious connections soon facilitated acquisition of over a thousand American clients for the Johnston firm. ${ }^{27}$

Richard Hayes states that between $177 \mathrm{I}$ and 1789 , Ireland alone imported almost double the amount of French wine that was imported into England, Scotland, and Ireland combined by the mid-nineteenth century. ${ }^{28}$

24 Hayes, 'Les Familles en Exil', 29.

25 Cullen, 'The Dublin Merchant Community in the Eighteenth Century', 200.

26 Charles Ludington, 'Politics and the Taste for Wine in England and Scotland: I660-I860,' I89.

27 Murphy, $A$ Kingdom of Wine: A celebration of Ireland's Winegeese, 39.

28 Hayes, 'Liens Irlandais avec Bordeaux', 18. 
Table I: Bordeaux Wine Exports, $1739-1740^{29}$

\begin{tabular}{|c|c|c|}
\hline Denominated Style of Wine & Destination of Export & Wine in Tuns \\
\hline Grand wines & England & 3,000 \\
\hline Fine wines & England & 7,000 \\
\hline Fine wines & Scotland & 25,000 \\
\hline Fine wines & Ireland & 40,000 \\
\hline
\end{tabular}

Table I indicates that mid-eighteenth-century Ireland was Bordeaux's most significant export customer for fine claret and that Lord Chesterfield's concerns about the Irish gentry ruining themselves through excessive expenditure on claret were not misplaced. ${ }^{30}$

Table 2: French Wine Imports into Ireland, $177 \mathrm{I}-18 \mathrm{II}^{31}$

\begin{tabular}{|c|c|}
\hline Year imported into Ireland & French Wine in Tuns \\
\hline I 77 I - I 780 & 27,802 \\
\hline I 78 I-I 790 & 20,883 \\
\hline I 79 I-I 800 & I I, 605 \\
\hline I $800-$ I 8 I I & 4,876 \\
\hline
\end{tabular}

Table 2 illustrates the fact that Irish claret consumption dramatically decreased in the years approaching the Act of Union (1800), and in its immediate aftermath.

29 Murphy, 35. It is assumed here that Murphy's reference to 'Grand wines' implies first growths only.

30 Lord Chesterfield, cited in Clarkson, 'Hospitality, housekeeping and high living in eighteenth-century Ireland', 84 .

3I C. Moreau, French Consul in London, I827, cited in Hayes, 'Liens Irlandais avec Bordeaux', 18 . 


\section{Hospitality in Georgian Ireland}

An American traveller, Edward Melville, visiting Bordeaux in I 805, fairly tripped over Hibernians, noting that 'there are vast numbers of Irish in this city. ${ }^{32}$ Melville lived for a time in Bordeaux, from whence he travelled to Ireland, where he primarily socialized in the cities of Cork and Dublin. Consequently, he was well placed to draw comparisons between his French and Irish hosts and acquaintances. Prior to quitting Bordeaux, he had been warned that the Irish were 'sad drunkards. ${ }^{33}$ Upon arrival in Cork, Melville was promptly entertained by the brother of an Irish acquaintance in Bordeaux. Brief exposure to Cork hospitality led Melville to marvel that, in Ireland, he experienced:

three meals crowded into less than six hours, which would be fully sufficient for the temperate French in twenty four, and as much wine consumed as would serve the same number of Frenchmen, mixed with water, for a week. ${ }^{34}$

Melville frequently expressed great fondness for the Irish, but found that their gastronomic regime rendered him 'heartily sick.' ${ }^{35}$ He was not the first visitor to Ireland to fear that his hosts might endanger his well-being through the extravagant nature of their hospitality. The distinctive quality of Irish hospitality had long been a source of amazement to visitors, ${ }^{36}$ and it is an invariable leitmotif in the writings of diarists and travellers to Ireland in the Georgian period. ${ }^{37}$ John Booth postulates that the national

\section{Printed for the Author, I8II), I37.}

33

Edward Melville, Sketches of Society in France and Ireland, Years I805-6-7 (Dublin:

Melville, Sketches of Society in France and Ireland, Years I805-6-7, 2.

Melville, Sketches of Society in France and Ireland, 85.

Melville, Sketches of Society in France and Ireland, 85.

Richard Stanihurst, De rebus in Hibernia gestis (Antwerp, I584), 33.

See Mrs Delany, cited in Katherine Cahill, Mrs Delany's Menus, Medicines and Manners (Dublin: New Island, 2005); De Bougrenet De Latocnaye, A Frenchman's Walk Through Ireland 1796-7, trans. J. Stevenson (Belfast: The Blackstaff Press, 1984); Benson E. Hill, Recollections of an Artillery Officer Including Scenes and Adventures 
tendency towards excess is linked to traditional admiration for the gargantuan feasts depicted in Irish mythology: he says the Tuatha Dé Danaan (people of the goddess Dana) 'celebrated for their incredible eating and drinking habits', feature in such tales. ${ }^{38}$ Historically, Protestants had perceived the Irish natives' adherence to modes of hospitality that were part of the Gaelic tradition as (yet another) negative characteristic. Paradoxically, from 1600-1800, the Anglo-Irish adopted these very modes of exaggerated hospitality. ${ }^{39}$ Mary Delany, whose wealth of letters provides so much valuable detail about upper-class life in eighteenth-century Ireland, observed of the citizenry that 'no people can be more hospitable or obliging. ${ }^{40}$ She voiced that opinion in 1732 , the same year in which another visitor to Ireland noted that 'the Irish Gentry are an expensive people: they live in the most open hospitable manner, continually feasting with one another. ${ }^{31}$ De Latocnaye reported that even the wretched (usually Catholic) poor would offer a stranger their all - forcing their meagre food supplies upon one - the imperative to hospitality being so deeply ingrained in the national psyche. ${ }^{42}$

A substantial element of élite hospitality was vinous in nature, and, more often than not, supplied in the form of claret. This liquid was consumed on such an overwhelming scale that the Earl of Chesterfield, during

in Ireland, America, Flanders, and France, Vol. I. (London: Richard Bentley, I836); Hermann Pückler-Muskau, 'The Adventures of Prince Pückler-Muskau in England, Wales and Ireland', The Tourist's Gaze: Traveller's to Ireland I800-2000, ed. Glenn Hooper (Cork: Cork University Press, 200I), 37-4I.

38 John Booth, A Toast to Ireland: A Celebration of Traditional Irish Drinks (Belfast: The Blackstaff Press, 1995), i9.

39 Mac Con Iomaire, 'The Emergence, Development and Influence of French Haute Cuisine on Public Dining in Dublin Restaurants 1900-2000: An Oral History', $\mathrm{PhD}$ thesis (Dublin Institute of Technology, 2009), 69.

40 Mrs Delany, cited in the Knight of Glin and James Peill, Irish Furniture (New Haven: Yale University Press, 2007), 60.

4I In John Loveday of Caversham, I7II-I789: The Life and Tours of an EighteenthCentury Onlooker, ed. Sarah Markham (Norwich: Michael Russell Publishing Ltd., I884), I24.

42 De Latocnaye, Jacques Louis de Bourgrenet, A Frenchman's Walk Through Ireland I796-7, 68 . 
his term as Lord Lieutenant in Ireland, famously despaired in 1745 that 'nine gentlemen out of ten are impoverished by the great quantity of claret [... drunk in their houses. ${ }^{43}$ Constantia Maxwell emphasizes that 'no one in any position in Dublin would have thought himself truly hospitable unless he provided large quantities of claret for his guests. ${ }^{34}$ Such a stance is unsurprising when one considers that the individuals responsible for setting the ton in Irish society - the Lords Lieutenant - were punctilious in terms of providing and consuming a quantity and quality of claret perceived as commensurate with their social standing. As viceroy, Charles Manners, the 4th Duke of Rutland ( $1784-1787$ ), despatched George Kendall, a member of his military staff, to France for the purpose of securing premium wines for Dublin Castle. ${ }^{45}$ Bordeaux links to Ireland were instrumental in ensuring that Kendall assembled a consignment of France's finest wines for the castle's cellars. The Archbishop of Narbonne, one Arthur Richard Dillon, a scion of the aforementioned Dillon family and a noted epicure who lived a life 'more gay than episcopal' assisted Kendall in fulfilling his mission. ${ }^{46}$

Viceregal banquets represented the apogee of élite entertainment in Georgian Dublin, and at these, wine quite literally flowed. A font gushing wine through the night was a particular feature of castle celebrations in the I730s and I750s during the two terms of office of Lionel Sackville, ist Duke of Dorset. Under the viceroyalty of Chesterfield in 1745 , the banquet held to mark the king's birthday saw the Castle's supper room transformed into a Temple of Minerva with statuary dispersed throughout and from which spouted a continuous flow of wine. ${ }^{47}$

43 Chesterfield, cited in Clarkson, 'Hospitality, housekeeping and high living in eighteenth-century Ireland', 84 .

44 Constantia Maxwell, Dublin Under the Georges, I7I4-1830 (London: Faber and Faber, 1946), IоI.

45 Joseph Robins, Champagne and Silver Buckles: The Viceregal Court at Dublin Castle, I700-I922 (Dublin: The Lilliput Press, 200I), 72.

46 Comtesse de Boigne, cited in Hayes, 'Biographical Dictionary of Irishmen in France', 485 .

47 Robins, Champagne and Silver Buckles, 27. 


\section{Honest claret}

The wine almost invariably preferred by polite society in Georgian-era Ireland was claret - certainly by those who could afford it. Jonathan Swift, writing to his friend Sir Charles Wogan in Spain in 1732, expressed his dismay at a recent increase of twenty percent in claret prices, due to a poor season. Swift thought he might be able to afford Spanish wine 'as like French claret' as could be obtained, 'such as our claret-drinkers here will be content with. For, when I give them pale wine [...] they say it will do for one glass, and then [...] call for Honest Claret'. Interestingly, Swift adds that if Wogan thinks such wine can be obtained, he would commission 'Mr Hall, an honest Catholic merchant here, who deals in Spanish wine' to import it for him. Despite the demands upon his purse, Swift considered wine essential to his health 'for my disorders [...] make it absolutely necessary to me. ${ }^{38}$ Swift, dubious about purchasing Spanish wine as a substitute for claret, evinces an oenophile's discernment. He was not unique in his preoccupation with quality or in his views about the health-giving properties of claret. In correspondence directed to his daughter, Bishop Edward Synge, between 21 June and I July 1749 , fretted that no one in his household had yet troubled to send him an opinion on a recent wine purchase. ${ }^{49}$ In 1783 , an Armagh gentleman, urged a convalescent friend to ignore the medical advice he was receiving, assuring him that 'It is not fit for you and me at our Time of Life to drink Water etc. [...] I beseech you not to drink less than a Bottle of good claret in condition after your dinner., ${ }^{50}$

48 Jonathan Swift cited in Works of the Rev. Jonathan Swift, D.D., Dean of St. Patrick's, Dublin, Volume XIX of XXIV, ed. Thomas Sheridan and John Nichols (New York: William Durrell and Co, 1813), 185 .

49 Bishop Synge, cited in The Synge Letters: Bishop Edward Synge to His Daughter Alicia, Roscommon to Dublin, $1746-1752$, ed. Marie Louise Legg (Dublin: Lilliput Press, 1996), 113-27.

so Cited in Clarkson, 'Hospitality, housekeeping and high living in eighteenth-century Ireland', $100-\mathrm{I}$. 
What was the style of this wine that so appealed to the Georgians? Prior to the Stuart Restoration, the claret exported from Bordeaux was generic in nature - light-bodied, and either a very pale red or a deep rosécoloured wine. The 'creation' in 1660 of Haut-Brion, the first 'branded' wine, according to Hugh Johnson, ushered in a new style of claret. ${ }^{51}$ HautBrion and other premium clarets that followed were advertised as 'new French clarets' and sold under specific estate or place names, such as Lafite, Margaux. Vinification methods and cellar practice must have improved concomitantly as Ludington notes that 'new' clarets were described in a London Gazette advertisement of I7II as 'deep, bright, fresh, neat'. He explains that 'deep' and 'bright' pertained to the wine's body and colour, 'fresh' to its age, and 'neat' to the fact that it was pure and unblended. ${ }^{52}$ The new luxury clarets were deeply coloured and, judging by the 'Ho Bryan' that Samuel Pepys tasted in 1663 , they had 'a good and most particular taste..53

Superior-grade claret was costlier than the ordinary version and was aimed at the upper echelons of society. A Dublin newspaper advertisement of 1750 called attention to the availability of 'choice Clarets of different growths, the vintage of 1747 and 1748 [...] Neat Claret of the Ist growth of Obrejone [...] at I 8s. per dozen. Neat Margoux [sic] and Medoc Claret at I6s. per dozen. Graves Claret at I4s. per dozen. ${ }^{54}$ Wealth enabled the Georgian gentleman to buy claret, but the salient factor in determining to whom it would be served was class; even ordinary claret was reserved for the enjoyment of the select few. In Kilkenny in 17I4, the provisioning of the celebrations for George I's accession to the throne was handled by a Captain Hedges who ensured that 'bottles of claret and glasses to drink His Majesty's health' were set out for the local gentry, whereas beer was laid on 'for the soldiers and inferior company.'55 Bishop Synge advised his daughter in 1750 that it would not be fitting to offer a prospective house-

5I Hugh Johnson, The Story of Wine (London: Mitchell Beazley Publishers, 1989).

52 Ludington, I55.

53 Cited in Johnson, The Story of Wine, 201.

54 'Curious Advertisements in 1750' [1833]. The Dublin Penny Journal, 2.53 (1833) 3.

55 S.J. Connolly, Religion, Law, and Power: The Making of Protestant Ireland I660-I760

(Oxford: Clarendon Press, 2002), I33. 
keeper and steward an 'allowance of Tea or Claret..5 In adjudging claret unsuitable for consumption by the socially inferior, Hedges and Synge tacitly recognized its significance as a marker of upper class status.

Quality wine for 'the quality' was the order of the day, but serving wine in quantity was just as important as being exacting about the calibre. Native Irish hospitality, imbibed (not just metaphorically) by the Protestant Ascendancy, demanded excess. There is evidence to suggest that manly bravado and ritual also influenced the drinking habits of the age. It should be noted that Dublin Castle was not simply the site of society roistering: the viceroy's role was political as well as social. Doubtless, certain viceroys used drinking sessions as a means of forging or consolidating social and political relationships and, additionally, as a means of gauging the character and strength of government participants and opponents alike. Heavy drinking, like combat, requires physical stamina. ${ }^{57}$

Influential Irish grandees were put to the test in 1755 when the new Lord Lieutenant, the Marquis of Hartington, hosted a stupendous drinking session at the castle. The eminent Lord Kildare withstood its rigours but wrote to his wife the following day that 'I don't think I ever drank so hard and fast in my life: everyone of the company complain today.' It is perhaps revealing that the Earl advised the Duchess that the participants 'all stay'd to the last.' They probably dared not do less. ${ }^{58}$ In 1736 , Lord Orrery opined:

Drunkenness is the Touch Stone by which they try every man; and he that cannot or will not drink, has a mark set upon him. He is abus'd behind his back, he is hurt in his property, and he is persecuted as far as the power of Malice and Intemperance can go. ${ }^{59}$

Bishop Synge, cited in Legg ed., The Synge Letters: Bishop Edward Synge to His Daughter Alicia, Roscommon to Dublin, $1746-1752,228$.

57 Ludington, 442.

58 Earl of Kildare, cited in Correspondence of Emily, Duchess of Leinster $173{ }^{1-I} 814$, vol. r., Brian Fitzgerald, ed. (Dublin: Stationery Office, I949), I6.

59 Lord Orrery, cited in Booth, A Toast to Ireland: A Celebration of Traditional Irish Drinks, 20. 
Orrery's judgment is corroborated by the comments of one English observer who recorded his perception of Irish drinking habits of the day: '... a middling drinker here will carry off his four bottles without being in the least apparently disordered. A man is looked upon, indeed, as nothing with his bottle here, that can't take off his gallon coolly. ${ }^{60}$ The terminology used by drinkers of the period emphasized the bravura nature of drinking sessions: for example, empty bottles were referred to as 'dead men', and casks were 'killed. ${ }^{61}$

Fondly recollecting 'Irish dissipation in 1778 ', Jonah Barrington reminisces that numerous toasts were the custom of the day as 'claret flowed'. ${ }^{62}$ Toasting was not necessarily an ad hoc option. At any official dinner, and especially at Castle banquets, protocol dictated that specific toasting rituals were followed. The purpose of these was to reinforce 'prevailing political and religious prejudices' through the regulation of matters ranging from determining which persons were to perform toasts, to stipulating to whom the toasts should be proposed, as MacCarthy Mór recounts. ${ }^{63}$ He provides the example of an early eighteenth-century Corporation of Dublin dinner, honouring a newly elected Lord Mayor and presided over by the Lord Lieutenant. Custom dictated that the latter propose a series of six specific toasts to honour members of the royal family and the decisive battle that led to the exile of James II. The Lord Mayor and other notables would have followed with further toasts - a typical feature of such events. Constantia Maxwell attributes the notoriously arduous nature of drinking sessions at Dublin Castle to 'the interminable toasts that were given, in accordance with the fashion of the times. ${ }^{64}$

60 John Bush, Hibernia Curiosa: A Letter from a Gentleman in Dublin to his Friend at Dover in Kent (Dublin: J. Potts and J. Williams, 1769), 26-7.

6I Ludington, 442.

62 Jonah T. Barrington, Recollections of Jonah Barrington (Dublin: The Talbot Press Limited, I826), 45.

63 MacCarthy Mór, Ulster's Office, I552-1800: A history of the Irish Office of Arms from the Tudor Plantations to the Act of Union (Little Rock, AR: Gryfons Publishers, 1996), I6I.

64 Maxwell, Dublin Under the Georges, I7I4-1830, IOI. 


\section{Bordeaux's best customer}

Writing about Ireland in the period between 1660 and 1800, David Dickson claimed that as the Irish gentry became a distinct cultural entity within the country, they 'attempted to model themselves on their English counterparts [...] usually with some Hibernian modification. ${ }^{65}$ In the context of hospitality, the issue was one of adoption rather than modification. The Anglo-Irish élite embraced the Gaelic standards of exaggerated hospitality so wholeheartedly that, ironically, its members attracted the very criticism from English commentators which they themselves had once levelled at the native Irish. John Bush summed up the views of the more querulous genre of English visitor to Ireland when he observed that: 'They pique themselves much on their hospitality in all parts of the kingdom [...] I am afraid, indeed, that too much of their boasted hospitality in every province has a greater right to be denominated ostentation. ${ }^{66}$ Bush took particular exception to a gentleman 'of the first rank and fortune in the kingdom' who prevailed upon another Englishman, new to Irish shores, to join his company, suggesting that as you are come over quite a stranger to the country, it behoves us to make it as agreeable as we can. There is a company of us to meet at the Black Rock [...] and, by Jesus, there is to be five or six dozen of claret to be emptied. ${ }^{37}$ Such prodigality could overwhelm the visitor; it caused even the more sympathetic French traveller, De Latocnaye, to reprovingly observe that: 'Les gens riches dépensent presque tous, plus que leur revenu, et ainsi sont toujours obligés d'avoir recours à des expédients ruineux pour soutenir leur dépense. ${ }^{68}$

65 David Dickson, New Foundations: Ireland $1660-1800$ (Dublin: Criterion Press, I987), iाo.

66 Bush, Hibernia Curiosa: A Letter from a Gentleman in Dublin to his Friend at Dover in Kent, I4-15.

67 Bush, 16.

68 Jacques Louis De Bougrenet De Latocnaye, Promenade D'Un Français Dans l'Irlande (Dublin: M. and D. Graisberry, I797), 2 I. 
Claret lubricated the social life of those of rank and fortune to such an extent that, even at the dawn of the Victorian age, its association with Ireland was still strong. Benson Hill, an English artillery officer, noted in his recollections that he had 'heard Dublin claret highly extolled in England'. ${ }^{69}$ In I829, the British Home Secretary, Sir Robert Peel, recalled of Edward Sneyd, that his wine-house, 'Sneyd, Barton and French': 'was the first in Dublin when I was in Ireland (in the I8Ios) and [...] I continued to have my wine from $\mathrm{Mr}$ Sneyd after I left: ${ }^{70}$ In North America, the Irish Johnston family of Bordeaux was stocking the cellars of the new republic's leading citizens with their clarets which had the imprimatur of no less a personage than the Marquis de Lafayette. ${ }^{71}$

In Georgian Ireland, to consume claret was a privilege enjoyed by those at the apex of the social order and it was an assertion of one's cultural identity. The food and drink choices of the élite were as much 'an element in refined sociability' as the material goods with which they surrounded themselves. ${ }^{72}$ To indicate their taste and status, the wine they chose above all others was claret, and to provide claret in quantity to guests was a social imperative rooted in the traditions of the disenfranchised native population. The influx of disenfranchised Irish Jacobites into Bordeaux led to the establishment of a significant wine-trading community there; in turn, it resulted in felicitous connections between hibernois négociants and wine merchants in Ireland. It was by virtue of these connections that the latter established a reputation for the excellence of their claret. The fact that they benefited from a position of privilege and favour is unsurprising since their suppliers in Bordeaux were frequently their own relatives, through blood or marriage: familial ties ensured optimal quality. Thus, the well-established

69 Hill, Recollections of an Artillery Officer Including Scenes and Adventures in Ireland, America, Flanders, and France, vol. I., 25.

70 History of Parliament Online (2012) SNEYD, Nathaniel (1767-1873) of Bawnboy and Ballyconnell, Co. Cavan/History of Parliament Online. <http://www.historyofparliamentonline.org/Volume/1790-1820/member/sneyd-nathaniel-1767-1823>. Accessed 20 April 2012.

7I Murphy, $A$ Kingdom of Wine, 39.

72 Barnard, Making the Grand Figure: Lives and Possessions in Ireland, $1641-1770,123$. 
Irish firms enjoying these enviable links and specializing in premium clarets were held in such esteem that they retained important clients and attracted new ones even into the Victorian era. France set the tone for gastronomy as it was experienced by the upper classes in eighteenth-century Ireland; the wines of Burgundy, Champagne and, in particular, those of Bordeaux, predominated in the cellars of the great houses. The renowned philosopher and tar-water enthusiast, George Berkeley, Bishop of Cloyne, lamented the Homeric scale of claret consumption by Georgian Ireland's élite. The tenacious nature of the kingdom's links with the Hibernian Chartronnais and their celebrated wines is neatly encapsulted in Berkeley's rhetorical query, 'Was there any kingdom in Europe so good a customer at Bordeaux as Ireland? ?73 


\section{Exporting a 'Sense of Place': \\ Establishment of Regional Gastronomic Identity Beyond National Borders}

Within their particular gastronomic DNA, many countries carry elements of their past and present beverage cultures, ones that are uniquely identified with a nation. In Ireland, significant examples would include Guinness, Irish whiskey and the Irish pub. The German nation has strong associations with beer and beer gardens; Scotland has established connections with whisky, haggis, shortbread and salmon. ${ }^{1}$ But of all modern cultures, it is that of France which is most typically portrayed as having the strongest gastronomic identity: it is based around the very French concept of 'terroir', and it is wine that most readily springs to mind when the beverage culture of France is discussed.

This essay will reflect upon novel ways in which the French oenological 'sense of place' might be exported beyond its national boundaries. Story and themed interactions are the suggested and innovative methodologies for achieving positive relationships between a geographically delimited wine product and an external market. It will be argued that, through such strategies, consumer perception can be enhanced, thus permitting realization of an emotional bond between consumer and the product and its defined region. Essential to creation of this form of 'tourism without travel' ${ }^{2}$ is the successful reification of regional gastronomic identity beyond its natural

I Andrew Jones and Ian Jenkins, 'A taste of Wales - Blas Ar Gymru: Institutional malaise in promoting Welsh food tourism products', Tourism and Gastronomy, ed. Anne-Mette Hjalager and Greg Richards (Oxford: Routledge, 2002), I25.

2 Mark McGovern, 'The Craic Market: Irish Theme Bars and the Commodification of Irishness in Contemporary Britain', Irish Journal of Sociology II.2 (2002), 94. 
borders, a process significantly assisted by the themed locations that act as 'cultural ambassadors' for the wine. ${ }^{3}$

\section{Wine as 'story'}

Wine means different things to different audiences. Some are interested purely in the drink itself, as a soothing agent of relaxation, or a social product that performs the same role as any other libation. Others view the taste of the drink as just one aspect of a complex gastronomic experience. For the latter consumer, it is the story of the wine which allows the complexity of its enjoyment to be experienced. The wine narrative can include many things: the place from which it comes, the people who made it, the weather conditions of the harvest that year, the history of the wine itself, the packaging, labelling and shape of the bottle, the adherence to specific regional legislation, and even events contemporaneous with the production and sealing of the wine. In his book Liquid Memory, acclaimed film maker Jonathan Nossiter suggests that 'wine is among the most singular repositories of memory known to man. ${ }^{4}$ The author compares this repository to museums and to novels and how they capture and share specific memories and moments in time. However, according to Nossiter, 'wine is unique because it is the only animate vessel of both personal memory - that of the drinker (or maker) and the subjectivity of his experience and the memory of that subjectivity - and communal memory. That is, it is communal to the extent that a wine is also the memory of the "terroir".' A specific wine is an unusual product in that it has within it the power both

3 Caroline Munoz and Natalie Wood, 'No rules, just right or is it? The role of themed restaurants as cultural ambassadors', Tourism and Hospitality Research 7.3-4 (2007), 244.

4 Jonathan Nossiter, Liquid Memory (New York: Farrar, Straus and Giroux, 2009), I3.

5 Nossiter, 2009, I3-I4. 
to tell the story of a particular place and to be the story of that particular 'place'. One can liken it to a book that might describe a place, experience or period in time. Having offered the reader an insight into what that place, experience or period entailed, the book could now be consumed. Through its consumption, the story of that 'place' is enhanced. To continue the analogy, the book offers the reader the added benefit of having been written, published, printed and then sealed at the very time period being described in that particular 'place'; the drinker is the privileged one who can break the time seal, open that 'book' and consume the story of that place - as intended by the original 'wine-author'.

A unique aspect of the wine story in the beverage world is the frequency with which its attributes are compared to those of humanity. In a recent television documentary, Paul Pontallier, director and winemaker at the world famous Château Margaux, suggests that 'wine is not just fermented juice, it can be philosophical, it is so close to ourselves, its life expectancy is more or less ours. ${ }^{6}$ The suggestion is that wine has the power to hold within the confines of its bottle, the memories, feelings and emotions that reflect its surrounding natural environment. Roger Scruton's description of Burgundy brings to life a particularly eloquent description of this unique animation:

To appreciate Burgundy as it really is you must leave it to mature for at least five years, after which time a strange transformation occurs in the bottle. The grape gradually retreats, leaving first the village, then the vineyard and finally the soil itself in the foreground. Historical associations come alive as tastes and scents, ancestral traits appear like submerged family features and that peculiar Burgundy nose, as distinctive as the nose of Cleopatra, sits at the rim of the glass like a presiding god. ${ }^{7}$

Of course, many modern branded wines, with little or no reflection of 'terroir' in their makeup, could not be included in that description, despite some occasional attempts at furnishing a story of sorts to embellish their profiles. Wine is a product that particularly reflects its association with

6 'Wine - The Faith', Wine, Episode 2. BBC 4 Television, 23 February 2009.

7 Roger Scruton, I drink therefore I am: A philosopher's guide to wine (London:

Continuum, 2009), 37 . 
a specific place through the expression of a number of factors: the grape variety, the soil, the vineyard aspect, the climate, the weather conditions and, of course, the winemaker. The 'place story' encompasses not only those factors that are in essence internal to the wine, but also factors that, while external to the product, form part of its 'sense of place. These elements include things such as the history of the vineyards, the vignerons' own story and other features that may be associated with the actual wine such as traditional linkage with foods, practices and events. It is the communication of all of these aspects which allows the story of the wine's place to be told. Among many consumers, particularly at the quality level of the market, there is a desire to hear that story of the wine's place; it is the communication and ultimate exportation of that sense of place which pose particular challenges for winemakers. With all these elements being crucial to developing a wine's identity, what are the innovative ways in which France might export that oenological 'sense of place' beyond its national boundaries? What important role can story play in developing positive relationships between foreign consumers and geographically delimited wine products? Before one could begin to understand the optimal French approach, there are one or two lessons that can be learned from New World wine producers and how they have gone about their own exportation of an oenological sense of place.

\section{Lessons from the New World}

For some time, the New World has been using the story of tradition to imply a long wine heritage that is in continuity with the past. In some cases, there have even been implied associations with the traditions of historic wine nations like France. Included in the New World's 'story of place' is a cultural dimension that has been very evident in the more recent promotion of their wines. There is considerable evidence that using the story of 
wine, and the cultural economy that forms part of that story, can encourage real connections between consumers of wine and the product itself.

Beginning in the 1980 s, the Australian wine industry grew from relatively modest levels to become the fourth largest exporter in the world of wine. ${ }^{8}$ Up until relatively recently, those wines have been heavily marketed on a low price point. Fruit-laden, value-for-money wines, such as Jacob's Creek and Thomas Hardy, were very much a part of the mass branding approach, and became very popular, especially in Irish markets. However, in the last decade, it became apparent that world markets were becoming less satisfied with these particular wines. In many places, a sophisticated consumer was emerging who demanded a more complex product that could offer more than a varietally labelled fruit drink in a glass. The origin of this demand stems from consumer education through media channels such as food programmes and magazine articles, and through other influences such as foreign travel, wine clubs, and enhanced opportunities for dining out. It has been suggested that consumers are now developing 'a quest for product story, a wine experience and an appreciation of its cultural qualities.' The Australian reaction to these new consumer demands has taken many forms including the development of a new general strategy entitled 'Directions to 2025'. This plan introduced new categories of Australian wines, ones which suggest a mirroring of the categorization enshrined in French appellation contrôlée laws. Wine Australia has also developed a number of promotional initiatives that aim at promoting a relationship between wine and consumers on a cultural level. Aylward describes this as the 'way in which wine's cultural and economic qualities can be woven into a much more enriched fabric. ${ }^{10}$ Recent examples of how Wine Australia has attempted this interweaving between a wine and the cultural sphere include their organization and publicizing of events such as The Wine Industry', Prometheus 26.4 (2008), 373.

9 Aylward, 374.

Io Aylward, 373 . 
Australia University Wine Championships ${ }^{11}$ and the Young Wine Writer of the Year competition. ${ }^{12}$ Lately, Wine Australia has also shown a lot of interest in international rugby and has organized wine-themed rugby events to coincide with international matches. ${ }^{13}$ Individual wine brands have also shown themselves keen to associate their wines with cultural events: the Jacob's Creek series of outdoor Hollywood movies shown on the lawns of their vineyard/visitor centre provides a recent example. ${ }^{14}$ One might also note their promotional involvement with the Hollywood movie Australia. These examples show that the new world wine sector values the importance of having a cultural economy attached to their wine.

Such an approach to cultural linkage in the beverage sector is not unique to wine products. Grace Neville, in her exploration of the commodification of Irish culture, suggests that Guinness has used a similar approach in French advertisements: by linking stout to Ireland's leading literary figures in advertisement campaigns, it is inferred that in some way the product has cultural parity with great Irish writers. She uses the following example of a French advertisement for Guinness to illustrate the point:

Dublin. Lieu idyllique pour vous initier à Joyce, Yeats, Becket, Shaw, et Behan. Dublin. Lieu historique de la production de la Guinness. Seamus Heaney, Roddy Doyle, Paul Durcan, vous avez l'embarras du choix. Et pour être honnête si vous êtes venu en simple visiteur pour le weekend, vous pourriez manquer de temps pour les apprécier tous à leur juste valeur. Alors pourquoi ne pas les associer: Heaney, Yeats, Guinness, Beckett, Joyce.

II Gemma McKenna, 'Oxford triumphs in University Wine Championships', Harpers Wine and Spirits Trade Review, 30 January 2012. Online at: <http://www.harpers. co.uk/news/news-headlines/I1650-oxford-triumphs-in-university-wine-championship.html>. Accessed 2 May 2012.

I2 Online at: <http://www.youngwinewriter.com/?page_id=23>. Accessed 24 April 2012.

I3 Jean Smullen, 'Wine Diary' 20II, <http://www.jeansmullen.com/index.php?option $=$ com_eventlist $\&$ Itemid=27\&func $=$ details\&did=645>. Accessed I 8 April 20 I2 2

I4 See: <http://www.barossa.com/events/20II/jcvcoutdoormovies.aspx $>$. Accessed 3 May 2012. 
[Dublin, an idyllic city in which to absorb writers like Joyce, Yeats, Beckett, Shaw and Behan. Dublin, the historical home of Guinness. Seamus Heaney, Roddy Doyle, Paul Durcan, you have such an embarrassment of choice. And to be honest, if you arrived in the city as an ordinary weekend tourist, you might well not have sufficient time to appreciate all these riches properly. So why not just lump them all together: Heaney, Yeats, Guinness, Beckett, Joyce. $]^{15}$

These are successful examples of active involvement by the beverage world in developing and projecting the cultural economy of their products; but this is only part of their strategy. The true essence of a wine's sense of place lies in its story, and the communication of this story, as described above, is what Aylward ultimately refers to as 'the fabric of culture that is attached not to buildings, icons or performances, but to community interaction, collective and individual belief systems, a product's anthropological value, or the sense of place and purpose that becomes inherently bound within that product's development. ${ }^{16}$ It can prove more difficult to export this sense of place but again the New World has made a number of efforts in this regard. There have been attempts, through a variety of programmes, to bring the sense of place associated in particular with Australia's better wines into various export markets. Examples include Wine Australia's Regional Heroes Series, their Wine Ambassadors Initiative and their Ambassador's Shop Programme. These are strategies for potential markets, aimed at promoting and giving particular exposure to the story of the wine's place of origin. It is an attempt to achieve, to some degree, what McGovern refers to as 'tourism without travel.' ${ }^{17}$ That is to say, the consumer is given 'story of the place' without the necessity for being physically present in that location. Although McGovern's reference specifically relates to the influence

I5 Grace Neville, 'The Commodification of Irish Culture in France and Beyond', France and the Struggle against Globalization: Bilingual Essays on the Role of France in the World, ed. Eamon Maher and Eugene O’Brien (Lewiston, NY: Edwin Mellen Press, 2007), I5I-2.

I6 Aylward, 380.

I7 Mark McGovern, 'The Cracked Pint Glass of the Servant: The Irish Pub, Irish Identity and the Tourist Eye', Irish Tourism: Image, Culture and Identity, ed. Michael Cronin and Barbara O’Connor (Clevedon: Channel View Publications, 2003), 91. 
of the Irish Theme Pub in an emerging global culture, clear comparisons can be drawn with Wine Australia's attempt to use the story of place to influence that same global market. McGovern has also suggested that one of the characteristics of late capitalism is that commodities possess an exchange value that is based on their cultural associations. ${ }^{18}$ It seems clear that by telling the story of a wine's place, Wine Australia allows this cultural association to be reified and thus become an important part of the commodities' makeup. Thereby, it helps to differentiate a product from brands that may not possess that same cultural capital.

\section{'Cultural ambassadors' and themed locations}

Just as the New World has drawn greatly from the 'Old World' in terms of its wine-making origins, perhaps the old world has something to learn from countries like Australia. When it comes to commodifying gastronomic culture to help compete in a highly globalized market, there is little doubt that countries like France are playing catch-up in this regard. However, some recent innovative examples show how the French wine industry is starting to valorize the story of place that can be associated in a very real way with its wine products.

McGovern's concept of 'tourism without travel' suggests that there are opportunities for consumers to experience a place through routes other than physically visiting the actual location. These means can include things like stories and associations that help to commodify the wine's culture and allow it to travel and to be experienced. The suggestion by Munoz and Wood that themed locations act as 'cultural ambassadors' outside their home countries is particularly relevant. ${ }^{19}$ Their study, explored the influence of themed restaurants on a host nation's cultural perception of 
the themed country. The examples of Cahors Malbec, Muscadet Zenith, Inter Rhône and Beaujolais Nouveau show how particular French wine stories can indeed travel into communities outside the wine region itself and can act, to some degree, as ambassadors of cultural associations.

\section{Cahors Malbec: out of the vineyard and into the town}

Cahors wine, coming from vineyards mainly to the west of the ancient town of Cahors, is described by Larousse as one of the finer red wines of southwest France. ${ }^{20}$ The region has a long wine history and in the early nineteenth century, according to Jancis Robinson, the area was famed for the 'Black wines of Cahors. ${ }^{21}$ In recent years, Cahors has done a lot to develop and promote its own story. Undoubtedly, this has been in part a response to the Argentinean association with Cahors' original malbec grape, and to its relatively recent success in key markets such as the UK and the US. The main strategist behind the Cahors marketing campaign since 2006 is UIVC (Union Interprofessionnelle des vins de Cahors) Marketing Director Jérémy Arnaud and the approach is multifaceted. At a 2007 conference entitled 'Black Paradox', the colour influence of the wine's association with the colour black was discussed not only by wine experts but also by a sociology Professor from the Sorbonne, and by a writer with expertise in exploring emotional responses to colour. ${ }^{22}$ From that first conference has stemmed the development of a number of key initiatives that anchor the wine to its oenological sense of place. The Cahors strategy appears to incorporate the

Christopher Foulkes, Larousse Encyclopedia of Wine (London: Octopus Publishing, 200I), $30 \mathrm{I}$.

2I The Oxford Companion to Wine, ed. Jancis Robinson (Oxford: Oxford University Press, 1994), I74.

Tom Fiorina, 'Black is back: Cahors Malbec returns to the world stage', The Vine Route, 2I March 2010 <http://www.thevineroute.com/southwest/black-is-backcahors-malbec/>. Accessed I6 April 2012. 
commodification of the culture and story surrounding their wine, promoting them every bit as much as the quality of the product itself. It includes things like the launching of the Cahors blog on blackisphere.fr: its striking presentation and layout are heavily themed to reflect the wine's historical association with the colour black. The blog provides a forum for the communication of events and topics of interest which relate to the wines of Cahors. ${ }^{23}$ Cahors also developed CahorsMalbec.com, an English Language website that directly targets the US and UK markets while at the same time reinforcing the message that Cahors is the true home of malbec, with the history of the place and that grape very much intertwined. ${ }^{24}$

Another innovative approach to exporting the story of Cahors wines involved the development of the Cahors wine glass. An original glass design was commissioned and it is now being promoted in the hope that people will associate that glass with the story of Cahors. The glass design is particularly interesting in terms of commodifying and exporting an oenological sense of place in that it allows the story of Cahors malbec to be physically transported outside the region itself by visitors to that area. The role of the design in exporting the story of Cahors is to result in that story being told in places other than the region itself. One additional initiative involved the development of the Cahors Malbec Lounge in the heart of Cahors town itself. The lounge opened in the revamped Maison du Vin and its design is very reflective of the deep malbec grape colour and the distinctive Cahors glass. Of particular interest is the fact that the Malbec Lounge not only caters for tastings and tours but it also hosts a range of cultural/community events such as music concerts and events themed with Cahors tastings and with the wine itself. These included a recent 'Malbec In Love' soirée, a 'Speed Wine Dating' experience, and an event entitled 'Malbec Black Jack.' It can be suggested that there is a comparison to be drawn between events such as these and previous Australian examples in attempting to develop the

25 'Cahors rejuvenates wine tourism', <http://tdv.enprojet.net/cahors-rejuvenateswine-tourism/?lang=en/ 6 décembre 20II >. Accessed 6 April 2013. 
wine's cultural economy. Cahors has successfully begun to export the story of its wine, so rich in history and tradition, beyond the vineyard, beyond the town and beyond the South West region itself. Through its story, its glass, its blog, its website and the Cahors Malbec Lounge, people can now experience Cahors' sense of place well beyond the vineyard.

Muscadet Zenith: out of the vineyard and into the city

Cahors is not alone in its efforts to commodify and export elements of its gastronomic culture outside its regional borders. The development of the Bar Muscadet au Zenith at the Zenith Nantes Metropole Concert hall provides a very good example of both the exportation of 'sense of place' and the enhancement of 'cultural capital' that one might associate with a particular wine. That product is Muscadet, the flagship wine from the Loire region. In 201 I, this particular project was initiated by the trade organization Interprofession des Vins du Val de Loire. The initiative involves exposing up to 80,000 concert goers to a number of ambassador vintners who operate the Bar Muscadet au Zenith during a range of cultural events. So far, attendees at concerts as diverse as those by Motorhead, James Blunt and Lenny Kravitz have been exposed to the vintner ambassadors of the Loire. According to the promotional website 'Terre de vins': 'cette initiative représente un exemple inédit d'opération de communication et de dégustation visant à favoriser la réappropriation des vins de Nantes et de son appellation phare le Muscadet auprès d'un public local en associant son image à celle de grands événements culturels qualitatifs et innovants' [this initiative represents an unprecedented example of a communication and wine-tasting campaign which is aimed at promoting the rediscovery of the wines of Nantes and its 
flagship appellation, Muscadet, by associating its image with major cultural events that are both high-quality and innovative.$^{26}$

What makes this an example of exporting a sense of place, as opposed to simply a wine promotion, is the involvement of the ambassadors from the Loire regions and the use of very specific wines in the exercise. The sixteen ambassadors act not only as sales representatives but also as relationship formers between event goers and the physical place that is the Loire Muscadet region. To date, this approach appears to have proven quite successful and it is hard to see why such methods would not also work outside the Loire region. Two distinct outcomes are being achieved: firstly, the story of the wine's sense of place is being told to a wide variety of audiences; secondly, the wine is benefiting in terms of its cultural economy since, in the mind of consumers, it is gaining association with a particular range of cultural events. The thirty events that make up the 2012 contract included not only concerts but also musicals, modern circus acts, and even political debates.

\section{Inter Rhône: out of the vineyard and into other countries}

Inter Rhône is the organization that represents all wine merchants and growers in the Rhône valley. It has responsibility for the promotional, economic and technical needs of the region's wines. ${ }^{27}$ Inter Rhône offers two key examples of how it can export its regional gastronomic identity beyond national borders: first, through its Wine Educators Annual Programme; secondly, through use of its own brand ambassadors. Each year, Inter Rhône invites a number of 'key influencers' to a four or five-day educational trip in the Rhône valley. Usually, these would number three or four people each 20 décembre 20II $>$. Accessed 16 March 2013. 
from a number of different countries, and all with involvement in the wine trade whether as wine educators, journalists, sommeliers or promoters. This trip not only offers these influencers an opportunity to taste wines but, arguably, it instils in them a 'sense of place' associated with the region itself. As well as the more obvious exposure to tastings, the influencers are brought to meet with the vignerons themselves; they have the opportunity to interact with communities and families, and to walk the actual vineyards in their company. Thereby they are exposed to the typography, the people, the soil and the stories of the very vines. The Inter Rhône hope is that these influencers will then go on to spread the 'gospel of the Rhône' among their own communities and so export that sense of place outside the Rhône region and beyond the shores of France.

In addition to the educational programme, Inter Rhône organizes a team of brand ambassadors. They visit key market countries, offering free educational talks and tastings of the Rhône Valley wines. Linda Field, one of Inter Rhône's ambassadors, recently spent ten days in Ireland, travelling the country to deliver lectures and tastings to students of hospitality management programmes at a variety of third level centres. It could be argued that this is a form of McGovern's theory of 'tourism without travel': participants are enabled to experience the 'place' that is the Rhône wine region without actually travelling there.

\section{The Beaujolais Nouveau story: out of the vineyard and into the rest of the world}

One of the most successful examples of exporting an oenological 'sense of place' beyond national boundaries is the worldwide success that has been 'Beaujolais Nouveau Day'. Beaujolais, a wine region in the south of Burgundy, produces a range of excellent wines principally from the Gamay grape but it is best known worldwide because of the success of its Beaujolais Nouveau wine over many years. Originally this wine started out 
as a vin de primeur, that is, a wine drunk in the year it was made. It was sold in towns near the Beaujolais region and brought in much needed cash funds that allowed the vignerons to concentrate on their more complex wine production. In I951, Beaujolais was officially recognized through a set of regulations enforced by the Union Interprofessionnelle des Vins $d u$ Beaujolais (UIVB). Its official release date was set on is November. Over time, this local tradition of drinking the first Beaujolais of the season made its way to Paris and fans of Beaujolais began competing to be the first to bring the Beaujolais Nouveau to town following its annual official release at a minute past midnight on the is November. This date was officially changed to the third Thursday in November in 1985 , thus maximizing the winemaker's sales by guaranteeing the race for Beaujolais Nouveau always began in the run up to a weekend. ${ }^{28}$

The Beaujolais Nouveau story offers a clear example of how the tradition and heritage associated with a particular place can be used to export that sense of place, and indeed its story, throughout the world. Last year, the tradition of Beaujolais Nouveau celebrated its sixtieth year and, though recently less popular in some markets, it still accounts for distribution of some 50 million bottles. Of these, only around half are destined for the French market, while the rest are exported. The Japanese are now the world's biggest fans of the wine, ahead of the US and Germany. ${ }^{29}$

While these French examples from Cahors, the Loire, the Rhône and Burgundy, all show the benefits of exporting a regional gastronomic identity, it must be noted that there are also some examples where attempts to associate products with 'a sense of place' can go spectacularly wrong. Nike's recent St Patrick's Day branding of a style of running shoe is a case in point. As a tribute to a supposedly well-known Irish beverage, Nike branded their new trainers as 'Black and Tans'. They were correct in assuming that a 'Black and Tan' was indeed a drink made from mixing Guinness and ale; www.intowine.com/beaujolais2.html>. Accessed ıo March 2012. 
however, they failed to notice that many young modern Irish would not be familiar with this so-called traditional Irish drink but rather would know that 'Black and Tans' was the nickname given to unruly British army units made up of convicts who were sent to Ireland to viciously suppress revolts in the $1920 s$. The nickname has been immortalized in Irish folklore through its use in various anti-British songs such as Come out ye Black and Tans. The use of this name for a brand of trainer caused a media uproar and it led to a damaging press for Nike. ${ }^{30}$ Their attempt to link their product to Ireland by using a traditional drink identified with that particular 'place' resulted in Nike paying a high price for their mistake: as the media coverage highlighted, not only was the link tenuous since the Black and Tan drink is not popular in Ireland, but also the story associated with the history of that drink is an extremely negative one.

\section{Conclusion}

While actual travel can achieve greater consumer affinity with a product, and it is often an important outcome of the tourism experience, ${ }^{31}$ the exportation of a regional gastronomic identity, a form of McGovern's concept of 'tourism without travel', can equally enhance the relationship between wine consumers and the wine's regional identity outside its own natural borders. McGovern suggests that as long as it is enshrined and enveloped in the story of place, the wine itself may in some way act as the

30 Lee Moran, “'It's like calling a shoe the Al Qaeda”: Outrage as Nike names new trainer after British Black and Tans who cracked down on Irish in 1920 (just in time for St Paddy's Day!)', MailOnline I3 March 2012. < http://www.dailymail.co.uk/news/ article-2II 4278/St-Patricks-Day-themed-Nike-trainers-named-British-Black-Tanscause-outrage.html\#ixzzrrLdGBoFQ>. Accessed 3 April 2012.

3I Johan Bruwer and Karin Alant, 'The hedonic nature of wine tourism consumption: an experiential view', International Journal of Wine Business Research 21.3 (2009), 236. 
cultural envoy and it has the power to enhance the relationship between the consumer and the wine's delimited place of origin. To that end, the totality of a consumer's wine drinking experience is every bit as important in creating that affinity between wine and consumer, something that McGovern's Irish Pub abroad achieves by creating its own affinity between the consumer and Irish culture. There has been much recent research into the importance and value of the tasting room experience when it comes to developing such a relationship between wine and the consumer. However, because wine is a product that is so tied to a particular place, it is the story of that place that can cement the emotional bond between the product and the consumer. A 2006 report by the Wine Institute finds that: 'Winery visits are amongst the most significant sources of brand awareness and wine purchase decisions, due to the connection made by the visitor to a winery's brand story. ${ }^{32}$ The authors also state that the connection between winery and visitor will be most successful if it is not based solely on concrete links, but when there is also an emotional dimension to this connection. ${ }^{33} \mathrm{In}$ the cases mentioned throughout this essay, reference has been made to the innovative ways that countries might employ to export their oenological 'sense of place. The French examples showed how the exportation of that sense of place moved progressively away from the vineyard, firstly to the local town of Cahors, by way of the Cahors Malbec Lounge, secondly from the vineyard to the city in the form of the Muscadet bar at the Zenith Nantes Metropole, thirdly from vineyard to another country through the Inter Rhône Wine Educators and Brand Ambassadors Programme, and finally from the vineyard to the rest of the world through the historic success of Beaujolais Nouveau Day. The question that might be asked is whether a wine's story and its associated commodified culture can be removed from the vineyard and placed somewhere else? The examples in this chapter would seem to indicate that the answer is 'yes'. In addition,

Joanna Fountain, Nicola Fish and Steve Charters, 'Making a connection: tasting rooms and brand loyalty', International Journal of Wine Business Research 20.I (2008), 9. Fountain et al., I32. 
the advent of new communication technologies might prove useful in an ever-shrinking globalized economy and they would appear to make this approach all the more feasible. A recent New York Times article entitled 'Tasting Rooms, far away' says that in New York state, there are now fiftyfour satellite stores/tasting rooms attached to wineries state-wide, ones carrying only New York wines made from the state's own grapes. ${ }^{34}$ This would suggest that there is potential for further development in this area, and that there might now be an opportunity for the regional French wine sector to steal a march on the New World: it could do so by exporting its oenological sense of place outside its own borders, using the wine's entire story to build an emotional affinity between new consumers and its wine, a relationship based not only on the quality of the wine itself but also on its inherent gastronomic identity and infused with every feature of the story, place and cultural aspects that such an identity entails.

34 Howard G. Goldberg, 'Tasting rooms, far away', The New York Times, 30 December 20II, <http://www.nytimes.com/20I2/OI/oI/nyregion/setting-up-tasting-roomsfar-away-from-wineries.html>. Accessed 20 March 201 I. 



\section{Notes on Contributors}

MICHEL BRUNET is Senior Lecturer in English at the University of Valenciennes and Hainaut-Cambrésis, France. A graduate of the Universities of Paris and Lille, he wrote his doctoral thesis on William Trevor's short stories. His main areas of research lie in Irish literature, with a particular focus on Anglo-Irish writing. He also has a strong interest in Irish minorities and issues related to identity. His forthcoming publications include essays on George Moore and on contemporary Irish fiction.

DOROTHY CASHMAN is currently researching Irish culinary manuscripts and the culinary traditions of the landed estates and great houses of Ireland. She has presented papers at the inaugural Dublin Gastronomy Symposium on Dean Swift and the relationship with French culinary influence in Georgian Ireland, and to the Irish Georgian Society and the National Library of Ireland on researching the culinary manuscripts in the National Library's collection. This continuing research is supported by research funding from Fáilte Ireland.

KARINE DESLANDES is a lecturer in French at the University of Buckingham. After a Master's Degree by Research in Irish Studies at the University of La Sorbonne Nouvelle - Paris 3, she was awarded a PhD by the University of Ulster for her thesis on the reporting of the Northern Ireland Troubles in the French press. Author of Regardsfrançais sur le conflit nord-irlandais (in the series Studies in Franco-Irish Relations, Peter Lang, 2013), her ongoing research interest lies in Franco-Irish/British relations.

CONOR FARNAN completed his PhD studies on the poetry of Paul Durcan at Mary Immaculate College, University of Limerick. His research interests also include contemporary Irish poetry, gender and masculinities, ecocriticism and the works of James Joyce and John Moriarty. He is currently preparing for publication a monograph on the poetry of Paul Durcan. 
ANNE GOARZIN lectures in Irish literature at the Université Rennes 2. Her $\mathrm{PhD}$ specialized in the study of John McGahern's fiction and she is the author of the monograph Reflets d'Irlande, John McGahern (2002). She has edited several academic journals, including the Spring 20 I issue of Etudes Irlandaises entitled 'Perspectives on Trauma in Irish History, Literature and Culture'. She is currently co-editor of the French journal of Irish Studies, Etudes Irlandaises, and director of the CRBC (Centre de Recherche Bretonne et Celtique) at the Université Rennes $2-<$ http:// www.univ-rennes2.fr/crbc/cei>.

PIERRE JOANNON, a historian and one of the foremost specialists in France on the subject of Ireland, is the author of numerous books including Histoire de l'Irlande et des Irlandais (2006 and 2009) and Il était une fois Dublin (2013), and of the only French biographies of Michael Collins and John Hume. Founder of the Ireland Fund in France, he has been Honorary Consul General of Ireland in the South of France since 1973. Awarded Honorary Doctorates by the National University of Ireland and by the University of Ulster, he received one of the first annual Presidential Distinguished Service Awards for the Irish Abroad for his commitment to strengthening Franco-Irish relations (2012).

Benjamin Keatinge is Dean of the Faculty of Languages, Cultures and Communication at South East European University, Tetovo, Macedonia, where he teaches English literature. He holds a doctorate on Samuel Beckett from Trinity College Dublin and he has published articles on Beckett in the Irish University Review, the Journal of Modern Literature and in edited essay collections. He has published (as co-editor) a volume of critical essays on poet Brian Coffey titled Other Edens: The Life and Work of Brian Coffey (2010). He has also contributed essays on poets Richard Murphy, Pearse Hutchinson, Thomas MacGreevy and Harry Clifton to edited volumes as well as regular reviews to Poetry Ireland Review, the Irish University Review, the European English Messenger and The Beckett Circle. He currently lives in Skopje, Macedonia. 
EAMON MAHER is Director of the National Centre for Franco-Irish Studies at the Institute of Technology, Tallaght, Dublin, where he also lectures in Humanities. He is General Editor of the Reimagining Ireland book series with Peter Lang, Oxford, and he has edited and co-edited a number of books for that series. His latest book, co-edited with Eugene O'Brien, From Prosperity to Austerity: A Socio-Cultural Critique of the Celtic Tiger and its Aftermath, will be published in 2014.

TARA MCCONNELl is a PhD candidate at the Dublin Institute of Technology. Her research explores the provisioning of elite households in Georgian Dublin, with a particular focus on period trends in gastronomy and related material culture. She has presented papers at the Oxford Symposium on Food and Cookery (2010 and 2013), the inaugural Dublin Gastronomy Symposium (2012), the Eighth Annual Conference of the Association of Franco-Irish Studies (2012) and the inaugural Bishop Hervey Summer School (2013).

MICHÈLE Milan holds a MA in Translation Studies from Dublin City University, where she also received her $\mathrm{PhD}$ in 2013. Her doctoral research - funded under the PRTLI 4 scheme through An Foras Feasa, Maynooth was on Franco-Irish translation relationships in nineteenth-century Ireland, with a focus on English-language translators and with particular attention to Pierre-Jean de Béranger. Her ongoing research interests include translation, translation history, French and Irish studies, nineteenth-century studies and the history of women religious, as well as Breton studies and Irish traditional music.

BRIAN MURPHY lectures in hospitality, wine/beverage studies and gastronomy at the Institute of Technology, Tallaght, Dublin. Prior to his academic career, he spent a number of years working in management positions in the hospitality sector both in Ireland and abroad. In addition to his various academic qualifications, he has undertaken a number of professional wine courses over the years, culminating in the award of the WSET Diploma in Wines and Spirits. He has a particular interest in wine and gastronomy research and recently completed a $\mathrm{PhD}$ with the 
National Centre for Franco-Irish Studies which is based in the Institute of Technology, Tallaght.

EUGENE O'BRIEN is Head of the Department of English Language and Literature in Mary Immaculate College, University of Limerick. His publications include: Seamus Heaney - Creating Irelands of the Mind; Seamus Heaney and the Place of Writing; Seamus Heaney: Searches for Answers; and Kicking Bishop Brennan up the Arse: Negotiating Texts and Contexts in Contemporary Irish Studies. His latest book, From Prosperity to Austerity: A Socio-Cultural Critique of the Celtic Tiger and its Aftermath, co-edited with Eamon Maher, will be published in 2014.

MARY PIERSE teaches an Irish feminisms course for the Women's Studies MA at University College Cork. She compiled the five-volume Irish Feminisms 1810-1930 (2010). Editor of George Moore: Artistic Visions and Literary Worlds (2006), and (with Elena Jaime) George Moore and the Quirks of Human Nature (2014), she has also published on Kate Chopin, Arthur Conan Doyle, Antonio Fogazzarro and poets Dennis O'Driscoll and Cathal Ó Searcaigh. A board member at the National Centre for Franco-Irish Studies in the Institute of Technology, Tallaght, she serves on a number of editorial boards and scientific committees for publications in France and Spain. 


\section{Index}

I9I6 I2, I04 n.I 8, IIO, I62, I63

I968 3, 7, I00, I04, I09 n.28, III n.36, II , II 6, II 7, II 8

Académie Julian 62

Act of Union 1I, 36, 94 n.57, 214, 217, 230

Alliance Party 123

Anacreon 82

Anderson, Benedict II, I2, I89

Andrews, C.S. ('Todd') 106-7, III

Andrews, Malcolm $56 \mathrm{n} .58$

anecdote 36, 65, IOI, I3I, I83

Anglo Celt 40, 50, 5I

Anglo-Irish Agreement 116, I22, 125

Anglo-Irish Bank 157-8, 159, 166

Aran Islands 28, 67, 69 n.35, 73

Aughrim, Battle of 226

Austen, Jane 218

austerity $158,225 \mathrm{n} .9$

Austin, John Langshaw 186

Australia 54, 245-6, 247-8

autobiography 99, I00, I0I, I35

Badiou, Alain I0, I52-3, I58, I6I-2, I64

bailout IO, I49, I56, I58, I59, I60, I63,

$$
\text { 165, } 166
$$

Baker, Mrs A.W. 217, 218

Balthus (Balthasar Klossowski) I89, I9I, 194-5, 196-8, 200

Balzac, Honoré de 29, 6I

Baptists I17, I18, I25

Barbizon 61, 62, 63

Barry, James 6I
Barry, Michael Joseph 80, 87, 92

Barry, William 4I n.I5

Baudelaire, Charles 8, 26, 29, 96 n.66, I34, I82-3, I9I

Bazin, Hervé 134 n.3

Beaujolais 249, 253-4, 256

Beckett, Samuel 4, 29, 30, 33, 106,

$$
\text { 246-7 }
$$

Belloc, Hilaire 17-18, 21, 30, 31

Benjamin, Walter 8, 9 n.7, I83

Béranger, Pierre Jean de 5-6, 54, 79-97

Berkeley, George (Bishop) 240

Berkeley (University of California) 99,

$$
\text { 104, } 109
$$

Beyle, Henri (see Stendhal)

Bizet, Georges 54

Black and Tan 254-5

Bordeaux 5, 20, 223-40

Boudin, Eugène 6I

bouillon 210, 218

Bowen, Elizabeth 222

Boyne, Battle of the 226

Brady, Seán (Cardinal) I28

Breton 7, 59, 60, 61, 63-75

British Council of Churches I24

Brittany 7-8, 55, 59-76

Broderick, John 29

Brown, Terence 30, 170, 176-7

Burgundy 229, 240, 243, 253, 254

Burke, Augustus 63

Burke, Edmund 21, 22

Burke, Ray I5I

Byrne, Gabriel I 88

Byrne, Gay 180 
Cahors 249-51, 254, 256

Camus, Albert 133, 137

CAP (Common Agricultural Policy) 32

capitalism 136, 137, 138, I45, 156, 164, 165, 248

Casey, Eamonn (Bishop) 192

Catholic 6, 7, 17, 18, 20, 21, 22, 23, 24, 26, 29, 39, 47, 48-50, 66, 83, II2, II6, II7, II 8, II9, I2I, I23 n.36, I24, I25, I26, I28, I3O, I3I, I4O, I44, I8O, I89, 192, 195, 225, 226, 227, 232, 234

Catholic church I0, 20, 22, 49, I80, I8I Catholic Emancipation 36

cave art 20I-2

Celtic Tiger IO, II, I2, I40, I49, I56, I8I, 192

Celts 8, 17, 39, 68, 69 n.37, 70, 71, 72, 73 n. $47,89-90$

Chagall, Marc I89-94, 200

Chamberlain, Joseph 40

Champagne 229, 240

Charles X, King 107

chef 207, 208, 219

Chesterton, G.K. 24, 33-4

Civil Rights Movement 100

claret 223-40

Clifden 139-40

Cohn-Bendit, Daniel 106

Colley, Linda 18

Collins, Lucy 170, 187

Common Market 119

confectioner 208

Constable, John 56

consumer 52, 223, 24I-57

cookery book 207 n.2, 208, 210, 2II, 216

Corelli, Marie 53

Cork 24, 29, 38 n.7, 59, 64, 72, 79, 83, 93, 139, 229, 23I

Cork Examiner 38 n.7, 83, 190

Cork Review 190
Corkran, John Frazer 87, 89-90, 92

Corot, Camille 57,6I

corporation tax 140

Courbet, Gustave 57

Crawford Gallery (Cork) 59

Cromwell, Oliver 33, 173, 178, 185, 186-7

CRS (Compagnies Républicaines de Sécurité) I05

cuisine 4, 207-22

cultural ambassador $242,247,248-56$

cultural theory 152

Dáil 24, 32, I49

Danby, Francis 6I

Davis, Alex 67 n.30, 69

Davis, Francis 96

Davis, Thomas 54, 95, 172

de Gaulle, Charles 32, 102, 106

de Valera, Eamon $3 \mathrm{I}$

Deane, Seamus 67, 68, 69, 70 n.39, 7I

Defenders (secret society) 22

Degas, Edgar 27,57

Delacroix, Eugène 107, i10

Delaney, Mrs (of Delville) 215

demos (the people) $153-4,163,164-5$, I67

Denis, Maurice 65

Derrida, Jacques I53, I54-6, I60-I, I64, I67

Devlin, Bernadette I03

Diderot, Denis 39

Dillon family 227, 229, 233

Dostoyevsky, Fyodor 134

Dowe, William 89, 90

Dreyfus, Alfred (Captain) 39 n.9, 40

du Maurier, George 53

Dublin 4, 9, 24, 28, 29, 46, 47, 54, 55, 56, $57,84,99$, II 8, I21, I49, I62, I63, I76, I8I, I82, I83, I84, I93, 214, $217,224,227,231,233,235,237$, 239, 246-7 
Dublin Castle 162, 233, 236, 237

Dublin University Magazine 83,85

Dunne, Ben 150

DUP (Democratic Unionist Party) I24 n. 40, I25, I28, 129

Duran, Carolus 62

Durcan, Paul 4, I88, I89-203, 246-7

Eccles, Francis-Yvon 97

Edgeworth, Maria 80 n.3, 208, 214-16, 219, 221

elite 6I, I16 n.2, I23, I27, I63, I66, I76, 207, 208-9, 2I3, 2I4-I5, 2I9, 223-40

Elizabeth II, Queen 120, 126

epic 104, I70, I82, 184, 185-7, 198

Ervine, David 123

Europe 8, 17, 20, 28, 29, 31, 33, 36, 54, 60, $6 \mathrm{I}-2,64,67,68,69-70,72,75$, $79,85,86,94,130,136,144,145$, 167, 175, 180, 199, 209, 212, 224, 240

European Central Bank (ECB) I49, I56, I59, 160

European Commission 31-2, I30, I32, 156, 159

European Court of Human Rights I65

European Economic Community (EEC) 3I, II9

European Fiscal Compact I59

European Parliament 116, I25

European Security and Defence Policy (ESDP) 32

European Union (EU) 32, 33, I49, I65

Eva of the Nation (Mary Ann Kelly, née O’Doherty) 83, 85, 87, 88, 93

Fallon, Brian 25, 6I n.6, 66

Fenian Rising 36

Ferguson, Samuel 83, 89, I72

fête champêtre 220-I
Finlay, Thomas (Fr) 45

First Minister II5, I25, I28, I29, I3I

flâneur 9, I82-4

Flaubert, Gustave 53, 96 n.66, 100, IIo

Fontainebleau 62

Foster, Roy 28

France, Anatole 29

Francis, M.E. 5I

francophilia $19,25,30$

francophobia I8, 19, 4I n.15, 53 n.50

Franco-Prussian war 19, 24, 37, 38 n.7, 79

Free Presbyterian Church II7, II8, I20, I25

Freeman's Journal 39-40, 47, 84

French language II, 24, 27, 28, 44-6, 62 n.9, 80, 96, 220

French Revolution II, I2, I8 n.I, 21, 22, 4I, 8I, 106, I53, I67, 220

Gaiety Theatre 54

Galway 139, 227, 229

Garstin, Norman 62-3 n.13, 72

Gauguin, Paul 64-6, 72, 74

Gautier, Théophile 26, 88 n.29

Geithner, Timothy 157, 166, I67

George I, King 235

Gillet, Louis 28

Glasse, Hannah 207, 211, 212, 217

Glendinning, Robin 123-4

Goncourt, Edmond de 27

Gonne, Maud 28, 47, 189

Goodby, John 187

Good Friday Agreement I25, I27

Gounod, Charles 54

Grand Tour 72

Grattan, William 2I

Greece 158, 159, 186

Green, Julien I09

Griffith, Arthur 95

Gross Domestic Product (GDP) 157

Guinness 223, 24I, 246-7, 254 
Haughey, Charles I50, I51, 192

Haut-Brion 235

Heaney, Séamus 176, 246-7

Henry, Paul 71, 75-6

Herbert, Dorothea 208, 219-2I

Higgins, Michael D. 33

Hillery, Patrick 3I-2

Hoche, General Louis-Lazare 19, 23, 37, 42

Home Rule 40, 4I, 79

Hone, Nathaniel 64

Horace 82

hospitality 4, 5, 9, 212, 213, 214, 217, 222, 224, 225 n.9, 23I-3, 236-9, 253

Houellebecq, Michel 6-7, 133-45

Hovenden, Thomas 59, 60, 64, 72, 73

Hugo, Victor 134

Huguenot 227

Humbert, General Jean Joseph 19, 33, 37, 191

Hunt Museum (Limerick) 59

Hutchinson, Billy 123

Huysmans, Joris-Karl 27, 39, 53

Hyde, Douglas 42 n.18, 55 n.56

impressionism 57, 60, 6I, 64-6, 74

intellectual 18, 28, 30, 33, 39, 152, I53, 158 , I67, I7I, 172, 175

International Monetary Fund (IMF) Iо, I49, I56, I57, I59, I66

IRA II5, I20, I28, I29, I52

Irish Brigade 19, 37, 42

Irish Catholic Magazine 86 n.19, 88

Irish Colleges 19, 20-I, 226

Irish Free State 24, 163

Irish Independent 49, 169

Irish Jacobites 226, 228, 239

Irish People 83

Irish pub 4, IO, 24I, 247 n.17, 248, 256

Irish Times I04, IIO, III, 175
Jeanne d'Arc (see Joan of Arc)

Joan of Arc (Jeanne d'Arc) 4I, 46, 47, $48,51,52$

John Paul II (Pope) II6, I25 n.44, I 44

Johnston, Fred 176

Joyce, James I, 28-9, 30, 7I, I84, 246-7

justice $33,155,160-1,165,175,18 \mathrm{I}$

Kavanagh, Julia 56

Kavanagh, Patrick 29, 172-3

Kearney, Richard II-I2, 22

Keating, Seán 71, 75

Kelly, Morgan 157, 166

Kenny, Enda 158

Kennedy, John F. (President) I 44

Kennelly, Brendan 4, 9, 29, 169-88

Kerry 175,220

Kiberd, Declan I, I84

Kildare Observer 40

Kilkenny 217, 235

Klossowski, Balthasar (see Balthus)

kratos $\mathrm{I} 54, \mathrm{I} 65, \mathrm{I} 67$

La Varenne, François Pierre de 209, 2 Io, 213,218

Lacan, Jacques IO, I5I, I59, I6I, I64

Ladies' Land League 46

Lafayette, Marquis de 229, 239

Lafite 235

Larbaud, Valery 28

Lascaux I9I, I98, 20I-2

Latin Quarter 102, 108

Latocnaye, Jacques Louis de 232, 238

Lavery, Sir John 59 n.4, 62

Lawlor, Liam I5I

Le Braz, Anatole 69

L'Express II7, I21, I25, I26, I28, I30

Le Figaro I17, I18, I19, I20, I21, I22, I25, I26, I27, I29, I3O

L'Humanité II6, I18, I20, I21, I26,I27, 130 
Le Monde II6, II7, II8, I2I, I22, I25, I26, I27, I28, I29, I30, I3I

Le Nouvel Observateur III, II7, II9, I20, I2 I

Le Point $\mathrm{125}, \mathrm{I} 27, \mathrm{I} 28$

Lecky, William 19, 20, 39

Leonard, John Patrick 93-4

Leslie, Shane i9

liberal democracy 164

Libération 126, 127, 129

literary theory 152

Loire 25I-2, 254

Longley, Michael 170, 176, 177

Louis-Philippe, King 100, 107

Lowry, Michael I50, I5I

loyalist $115-32$

Lynch family 227

Lynch, Jack 31, 228

Lynch-Bages 227

MacHale, John 55

Maclise, Daniel 6I

Maginn, William 83, 86, 87, 92

Mahon Tribunal I0, I49-50

Mahon, Derek 29-30

Mahony, Francis (Father Prout) 83, 85, 86,92

Maillol, Aristide 57,65 n.23

Malbec 249-5I, 256

Mallarmé, Stéphane 26, 27, 28, I34

Malraux, André 106

Manet, Édouard 26,57

Mangan, James Clarence 85 n.I7, 172

Margaux 235, 243

Marlowe, Lara IIO

Mauriac, François 29

Maynooth 2I

McCall, P.J. 43

McCarthy, Justin 9I-2

McCarthy, M.J.F. 48-9
McDonagh, John 178

Meagher, Thomas Francis 24, 36

messianic I52, I6I-2, I64

Milligan, Alice 43

minotaur 191, 198-9

Mitchel, John 24

Monet, Claude 57,60

Montague, John 3-4, 7, 29, 99-II3

Moore, Brian 29

Moore, George 26, 27, 51-3, IOI

Moore, Thomas 54-5, 86 n.19, 89-90

morality I, 2, 52, 82, 9I-2, I3I, I49, I54-5, 189, 192

Morgan, Lady (Sydney Owenson) 25-6, $56,92-3$

Moriarty Tribunal I0, I49, I50

Morin, Edgar 109

Mulready, William 6r

Murphy Report I0, I49

Murray, Christopher 174-5

Muscadet 249, 251-2, 256

Muslim I36-7, I45

myth $2,17-34,58,60,8 \mathrm{I}-2,85-6$, 9I, I00, IIO-II, II2, II3, I85, I86, I99, 232

Nantes 5, 20, 226, 251, 256

Napoleon 5, 6, 17, 19, 25, 43, 8I-2, 85-6, 90-I, 95

Nation, The 51, 83, 84, 85, 86, 93, 95

National Gallery of Ireland 56, 57 n.62

National Library of Ireland 199, 217

naturalism 62, 64, 65, 68, 72, 73, 74-5, 193

Nenagh Guardian 40, 4I

Nerval, Gérard de 30, 134

Nietzsche, Friedrich 134

Nike 254-5

Norris, David I88

Northern Ireland 3, 7, 66, II2, II5-32

Northern Ireland Assembly I16, 125, 126, 
Ó Braonáin, Cathaoir (Fr) 84

O'Conor, Roderic 65, 66, 72, 74

O'Conor Eccles, Charlotte 40

O’Donovan Rossa, Diarmuid 43-4

O'Kelly, Aloysius 60, 63

O'Kennedy, Michael 3I-2

Orange Order I23, I3I

O'Toole, Fintan II, 163-4, I80

Owenson, Sydney (see Morgan)

Paisley, Ian 3, II5-32

Paris 3, 4, 8, 19, 20, 23, 24, 25, 26, 27, 28, $29,36,39,41,42,45,52,53,55,60$, $62,65,68,69,82,93,99-113,184$, 194, 208, 229, 254

Paris Commune IIO

Paris Review 134-5, I45

Parnell, Charles Stewart 36, 38, 49, 55

Pascal, Blaise 134-5, 138

Peace Process II5, I26-7

Peel, Sir Robert 239

Penal Laws 20

Pepys, Samuel 235

Persson, Åke $176,178,182$

Picasso, Pablo I91, 198-9

pietà 194-5

Pine, Richard 176

Platina 209

plein air 59, 60, 62

Pont-Aven 59, 60, 61, 62, 63, 65, 66, 74

Pope 4I, 49, 50, II6, II7, II 8, II9, I 44 popular 2, 5-6, 8, 35, 40, 47, 49, 55, 59, 6I, 63, 7I, 73, 80, 81, 82, 85, 86, $88,91,96$, I00, IOI, I22, I23, I38, I69-72, 176, I82, I85, I91, 212, 219, $22 \mathrm{I}, 224,225,245,254,255$

port 224

ports $56 \mathrm{n} .60,64,226$

post-impressionist 64 n.19, 74

Presbyterian 21, II7, II 8, I25, I26, 227, 229
Prix Goncourt 136, 138

Protestant 18, 20, 22, 23, 24, 6I, 66, 83, II5, II6-I7, II 8, I19, I22-5, I27, I3O, 131, 232, 236

Prout, Father (see Mahony, Francis)

PSNI (Police Service of Northern Ireland) 128

public imagination $\mathrm{I}-3,4,6-7,13,36$, 51, 66, 68,74, 96, 99, 100, 106, I09, IIO, III, II2, II3, I33, I36, I39, I45, I5 I, I52, I53, I6I, I64, I66, I7 I, $173,175,176,177,187,189-203$, 223

public sphere $\mathrm{I}-3,4, \mathrm{I} 2, \mathrm{I} 3,46, \mathrm{I} 53, \mathrm{I} 54$, I70, 179, I 80,182

Punch 27

Puvis de Chavannes, Pierre 57

Rancière, Jacques I0, I50, I64 n.47

recipe $207,208,209,210,217,218$

Réforme II6, II9, I24

Renan, Ernest 61, 69

republican 3, 6, I0, I2, 19, 22, 23, 25, 36, 66, 81, 82, 87, 92, 93, 94, 95, 109, I29, I30, 152

respublica $\mathrm{I53}, \mathrm{I54}, \mathrm{I} 64$

Restoration of Monarchy 5, 6, 82

Rhône 249, 252-3, 254, 256

Rimbaud, Arthur 29, 96 n.66, I9I

Ronayne, Joseph 79, 85 n.I6

Rouget de Lisle, Claude Joseph 54

roux 210

Rowland, John Thomas 84-5, 87, 90, 97 Royal Hibernian Academy 63

Ryan Report IO, I49

Sartre, Jean-Paul 133

Schopenhauer, Arthur 134

sex 27, 4I n.I5, II2, I23, I34, I36, I37, I38, 139, I4O, I4I, I42, 194, 195, 199, 203 
Shan Van Vocht 42-3, 46

Sherlock Holmes 53

Sinn Féin 42, 95, 128, 152

Smith O’Brien, William 36

sociology 180, 249

St Patrick's Day 47 n.39, 254

Staël, Madame de 25

Stendal (Henri Beyle) 5

Stephens, James 29, 36

Stock, Bishop 213

Stormont II6

Sullivan, T.D. 92

Sunningdale Agreement II6, I25

Sweeney, Anthony II

Swift, Jonathan (Dean) 224, 234

Synge, John Millington 8, 28, 67, 68, 70, 73,76

synthetism 65-6

Taylor, Samuel 68

terroir 5, 24I, 242, 243

Theatre Royal 54

Theme Pub 248

themed location 24I-2, 248-9

toasting 89,237

Tone, Wolfe 19, 23, 34, 43, 57

Trinity College Dublin 38, 179, 219

TV I2, I69, I78, I80, I82, 243

Twain, Mark 47

Ulster Workers' Strike (1974) II6, I25

UUP (Ulster Unionist Party) I27

UVF (Ulster Volunteer Force) I2I, I22
Vatel, François (chef) 219

Vatican 39 n.I0, 47, 50, II 8

Verlaine, Paul 27, 134

Victoria, Queen 219

vigneron 244, 253, 254

Vigny, Alfred de 134

Villiers de l'Isle Adam, Auguste 28

vineyard 243, 244, 246, 249, 251, 252, 253,256

Voltaire 6,39, 104

Washington, George 229

Waterloo 8I

welfare state 158

Westmeath Examiner 40

whiskey 223, 24I

White Soup 218

Wild Geese 5, 19, 27, 37, 226, 228

Wilde, Oscar 27, 55, 88

William IV, King 219

wine 4-5, 8I, IO8, I42, I43, 2I3, 2I 4, $223-40,24 \mathrm{I}-57$

Winegeese 228

Wordsworth, William 4, I06

Year of Liberty II, 37, 40, 190, 213, 215

Yeats, Jack B. 69 n.37, 75

Yeats, W.B. 26, 27-8, 71, 104 n.I8, IIo, I70, $17 \mathrm{I}-3,174,202,246-7$

Young Irelander $23,24,36,44,83,86,87$, I7 I, 172

Žižek, Slavoj Io, I58-9, I64, I67 n.5I

Zola, Émile 26, 27, 39, 40, 96 n.66 


\section{Reimagining Ireland}

Series Editor: Dr Eamon Maher, Institute of Technology, Tallaght

The concepts of Ireland and 'Irishness' are in constant flux in the wake of an ever-increasing reappraisal of the notion of cultural and national specificity in a world assailed from all angles by the forces of globalisation and uniformity. Reimagining Ireland interrogates Ireland's past and present and suggests possibilities for the future by looking at Ireland's literature, culture and history and subjecting them to the most up-to-date critical appraisals associated with sociology, literary theory, historiography, political science and theology.

Some of the pertinent issues include, but are not confined to, Irish writing in English and Irish, Nationalism, Unionism, the Northern 'Troubles', the Peace Process, economic development in Ireland, the impact and decline of the Celtic Tiger, Irish spirituality, the rise and fall of organised religion, the visual arts, popular cultures, sport, Irish music and dance, emigration and the Irish diaspora, immigration and multiculturalism, marginalisation, globalisation, modernity/postmodernity and postcolonialism. The series publishes monographs, comparative studies, interdisciplinary projects, conference proceedings and edited books.

Proposals should be sent either to Dr Eamon Maher at eamon.maher@ ittdublin.ie or to ireland@peterlang.com.

Vol. 1 Eugene O'Brien: 'Kicking Bishop Brennan up the Arse': Negotiating Texts and Contexts in Contemporary Irish Studies ISBN 978-3-03911-539-6. 219 pages. 2009.

Vol. 2 James P. Byrne, Padraig Kirwan and Michael O'Sullivan (eds): Affecting Irishness: Negotiating Cultural Identity Within and Beyond the Nation ISBN 978-3-03911-830-4. 334 pages. 2009.

Vol. 3 Irene Lucchitti: The Islandman: The Hidden Life of Tomás O'Crohan

ISBN 978-3-03911-837-3. 232 pages. 2009. 
Vol. 4 Paddy Lyons and Alison O'Malley-Younger (eds): No Country for Old Men: Fresh Perspectives on Irish Literature ISBN 978-3-03911-841-0. 289 pages. 2009.

Vol. 5 Eamon Maher (ed.): Cultural Perspectives on Globalisation and Ireland ISBN 978-3-03911-851-9. 256 pages. 2009.

Vol. 6 Lynn Brunet: 'A Course of Severe and Arduous Trials': Bacon, Beckett and Spurious Freemasonry in Early TwentiethCentury Ireland ISBN 978-3-03911-854-0. 218 pages. 2009.

Vol. 7 Claire Lynch: Irish Autobiography: Stories of Self in the Narrative of a Nation

ISBN 978-3-03911-856-4. 234 pages. 2009.

Vol. 8 Victoria O'Brien: A History of Irish Ballet from 1927 to 1963 ISBN 978-3-03911-873-1. 208 pages. 2011.

Vol. 9 Irene Gilsenan Nordin and Elin Holmsten (eds): Liminal Borderlands in Irish Literature and Culture ISBN 978-3-03911-859-5. 208 pages. 2009.

Vol. 10 Claire Nally: Envisioning Ireland: W.B. Yeats's Occult Nationalism ISBN 978-3-03911-882-3. 320 pages. 2010.

Vol. 11 Raita Merivirta: The Gun and Irish Politics: Examining National History in Neil Jordan's Michael Collins ISBN 978-3-03911-888-5. 202 pages. 2009.

Vol. 12 John Strachan and Alison O'Malley-Younger (eds): Ireland: Revolution and Evolution ISBN 978-3-03911-881-6. 248 pages. 2010.

Vol. 13 Barbara Hughes: Between Literature and History: The Diaries and Memoirs of Mary Leadbeater and Dorothea Herbert ISBN 978-3-03911-889-2. 255 pages. 2010.

Vol. 14 Edwina Keown and Carol Taaffe (eds): Irish Modernism: Origins, Contexts, Publics ISBN 978-3-03911-894-6. 256 pages. 2010. 
Vol. 15 John Walsh: Contests and Contexts: The Irish Language and Ireland's Socio-Economic Development ISBN 978-3-03911-914-1. 492 pages. 2011.

Vol. 16 Zélie Asava: The Black Irish Onscreen: Representing Black and Mixed-Race Identities on Irish Film and Television ISBN 978-3-0343-0839-7. 213 pages. 2013.

Vol. 17 Susan Cahill and Eóin Flannery (eds): This Side of Brightness: Essays on the Fiction of Colum McCann ISBN 978-3-03911-935-6. 189 pages. 2012.

Vol. 18 Brian Arkins: The Thought of W.B. Yeats ISBN 978-3-03911-939-4. 204 pages. 2010.

Vol. 19 Maureen O'Connor: The Female and the Species: The Animal in Irish Women's Writing ISBN 978-3-03911-959-2. 203 pages. 2010.

Vol. 20 Rhona Trench: Bloody Living: The Loss of Selfhood in the Plays of Marina Carr ISBN 978-3-03911-964-6. 327 pages. 2010.

Vol. 21 Jeannine Woods: Visions of Empire and Other Imaginings: Cinema, Ireland and India, 1910-1962 ISBN 978-3-03911-974-5. 230 pages. 2011.

Vol. 22 Neil O'Boyle: New Vocabularies, Old Ideas: Culture, Irishness and the Advertising Industry ISBN 978-3-03911-978-3. 233 pages. 2011.

Vol. 23 Dermot McCarthy: John McGahern and the Art of Memory ISBN 978-3-0343-0100-8. 344 pages. 2010.

Vol. 24 Francesca Benatti, Sean Ryder and Justin Tonra (eds): Thomas Moore: Texts, Contexts, Hypertexts ISBN 978-3-0343-0900-4. 220 pages. 2013.

Vol. 25 Sarah O'Connor: No Man's Land: Irish Women and the Cultural Present ISBN 978-3-0343-0111-4. 230 pages. 2011. 
Vol. 26 Caroline Magennis: Sons of Ulster: Masculinities in the Contemporary Northern Irish Novel ISBN 978-3-0343-0110-7. 192 pages. 2010.

Vol. 27 Dawn Duncan: Irish Myth, Lore and Legend on Film ISBN 978-3-0343-0140-4. 181 pages. 2013.

Vol. 28 Eamon Maher and Catherine Maignant (eds): Franco-Irish Connections in Space and Time: Peregrinations and Ruminations ISBN 978-3-0343-0870-0. 295 pages. 2012.

Vol. 29 Holly Maples: Culture War: Conflict, Commemoration and the Contemporary Abbey Theatre ISBN 978-3-0343-0137-4. 294 pages. 2011.

Vol. 30 Maureen O'Connor (ed.): Back to the Future of Irish Studies: Festschrift for Tadhg Foley ISBN 978-3-0343-0141-1. 359 pages. 2010.

Vol. 31 Eva Urban: Community Politics and the Peace Process in Contemporary Northern Irish Drama ISBN 978-3-0343-0143-5. 303 pages. 2011.

Vol. 32 Mairéad Conneely: Between Two Shores / Idir Dhá Chladach: Writing the Aran Islands, 1890-1980 ISBN 978-3-0343-0144-2. 299 pages. 2011.

Vol. 33 Gerald Morgan and Gavin Hughes (eds): Southern Ireland and the Liberation of France: New Perspectives ISBN 978-3-0343-0190-9. 250 pages. 2011.

Vol. 34 Anne MacCarthy: Definitions of Irishness in the 'Library of Ireland' Literary Anthologies ISBN 978-3-0343-0194-7. 271 pages. 2012.

Vol. 35 Irene Lucchitti: Peig Sayers: In Her Own Write ISBN 978-3-0343-0253-1. Forthcoming.

Vol. 36 Eamon Maher and Eugene O'Brien (eds): Breaking the Mould: Literary Representations of Irish Catholicism ISBN 978-3-0343-0232-6. 249 pages. 2011. 
Vol. 37 Mícheál Ó hAodha and John O'Callaghan (eds): Narratives of the Occluded Irish Diaspora: Subversive Voices ISBN 978-3-0343-0248-7. 227 pages. 2012.

Vol. 38 Willy Maley and Alison O'Malley-Younger (eds): Celtic Connections: Irish-Scottish Relations and the Politics of Culture ISBN 978-3-0343-0214-2. 247 pages. 2013.

Vol. 39 Sabine Egger and John McDonagh (eds): Polish-Irish Encounters in the Old and New Europe ISBN 978-3-0343-0253-1. 322 pages. 2011.

Vol. 40 Elke D'hoker, Raphaël Ingelbien and Hedwig Schwall (eds): Irish Women Writers: New Critical Perspectives ISBN 978-3-0343-0249-4. 318 pages. 2011.

Vol. 41 Peter James Harris: From Stage to Page: Critical Reception of Irish Plays in the London Theatre, 1925-1996 ISBN 978-3-0343-0266-1. 311 pages. 2011.

Vol. 42 Hedda Friberg-Harnesk, Gerald Porter and Joakim Wrethed (eds): Beyond Ireland: Encounters Across Cultures ISBN 978-3-0343-0270-8. 342 pages. 2011.

Vol. 43 Irene Gilsenan Nordin and Carmen Zamorano Llena (eds): Urban and Rural Landscapes in Modern Ireland: Language, Literature and Culture ISBN 978-3-0343-0279-1. 238 pages. 2012.

Vol. 44 Kathleen Costello-Sullivan: Mother/Country: Politics of the Personal in the Fiction of Colm Tóibín ISBN 978-3-0343-0753-6. 247 pages. 2012.

Vol. 45 Lesley Lelourec and Gráinne O'Keeffe-Vigneron (eds): Ireland and Victims: Confronting the Past, Forging the Future ISBN 978-3-0343-0792-5. 331 pages. 2012.

Vol. 46 Gerald Dawe, Darryl Jones and Nora Pelizzari (eds): Beautiful Strangers: Ireland and the World of the 1950s ISBN 978-3-0343-0801-4. 207 pages. 2013.

Vol. 47 Yvonne O'Keeffe and Claudia Reese (eds): New Voices, Inherited Lines: Literary and Cultural Representations of the Irish Family ISBN 978-3-0343-0799-4. 238 pages. 2013. 
Vol. 48 Justin Carville (ed.): Visualizing Dublin: Visual Culture, Modernity and the Representation of Urban Space ISBN 978-3-0343-0802-1. 326 pages. 2014.

Vol. 49 Gerald Power and Ondřej Pilný (eds): Ireland and the Czech Lands: Contacts and Comparisons in History and Culture ISBN 978-3-0343-1701-6. 243 pages. 2014.

Vol. 50 Eoghan Smith: John Banville: Art and Authenticity ISBN 978-3-0343-0852-6. 199 pages. 2014.

Vol. 51 María Elena Jaime de Pablos and Mary Pierse (eds): George Moore and the Quirks of Human Nature ISBN 978-3-0343-1752-8. 283 pages. 2014.

Vol. 52 Aidan O'Malley and Eve Patten (eds): Ireland, West to East: Irish Cultural Connections with Central and Eastern Europe ISBN 978-3-0343-0913-4. 307 pages. 2014.

Vol. 53 Ruben Moi, Brynhildur Boyce and Charles I. Armstrong (eds): The Crossings of Art in Ireland ISBN 978-3-0343-0983-7. 319 pages. 2014.

Vol. 54 Sylvie Mikowski (ed.): Ireland and Popular Culture ISBN 978-3-0343-1717-7. 257 pages. 2014.

Vol. 55 Benjamin Keatinge and Mary Pierse (eds): France and Ireland in the Public Imagination ISBN 978-3-0343-1747-4. 279 pages. 2014. 


\section{IRISH \\ UNIVERSITY

$40 \mathrm{TH}$

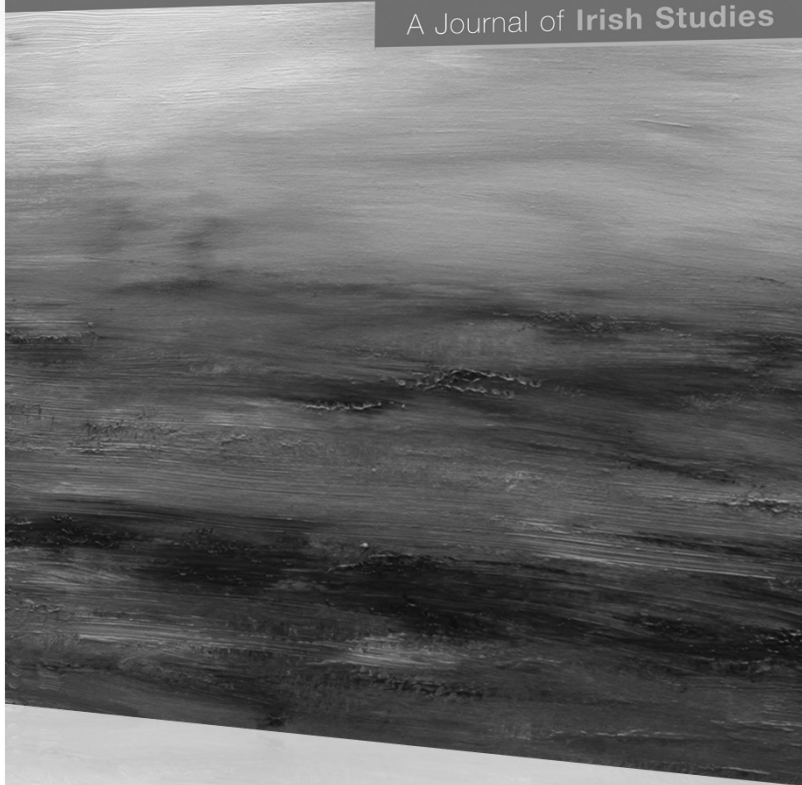

Established in 1970, the Irish University Review is the leading journal of Irish literary studies. It publishes the best current criticism and scholarship, an extensive review section, and the IASIL annual bibliography of Irish Studies.

The 'special issues', published annually, and devoted to the work of a particular author, or a topic of current interest in Irish Studies, have shaped and defined the field.

To find out more, and for details of how to subscribe, please visit our website.

$$
\text { www.irishuniversityreview.ie }
$$

